Prepared in cooperation with North Carolina State University, New Mexico State University, and Boise State University

\title{
Gap Analysis Project (GAP) Terrestrial Vertebrate Species Richness Maps for the Conterminous U.S.
}
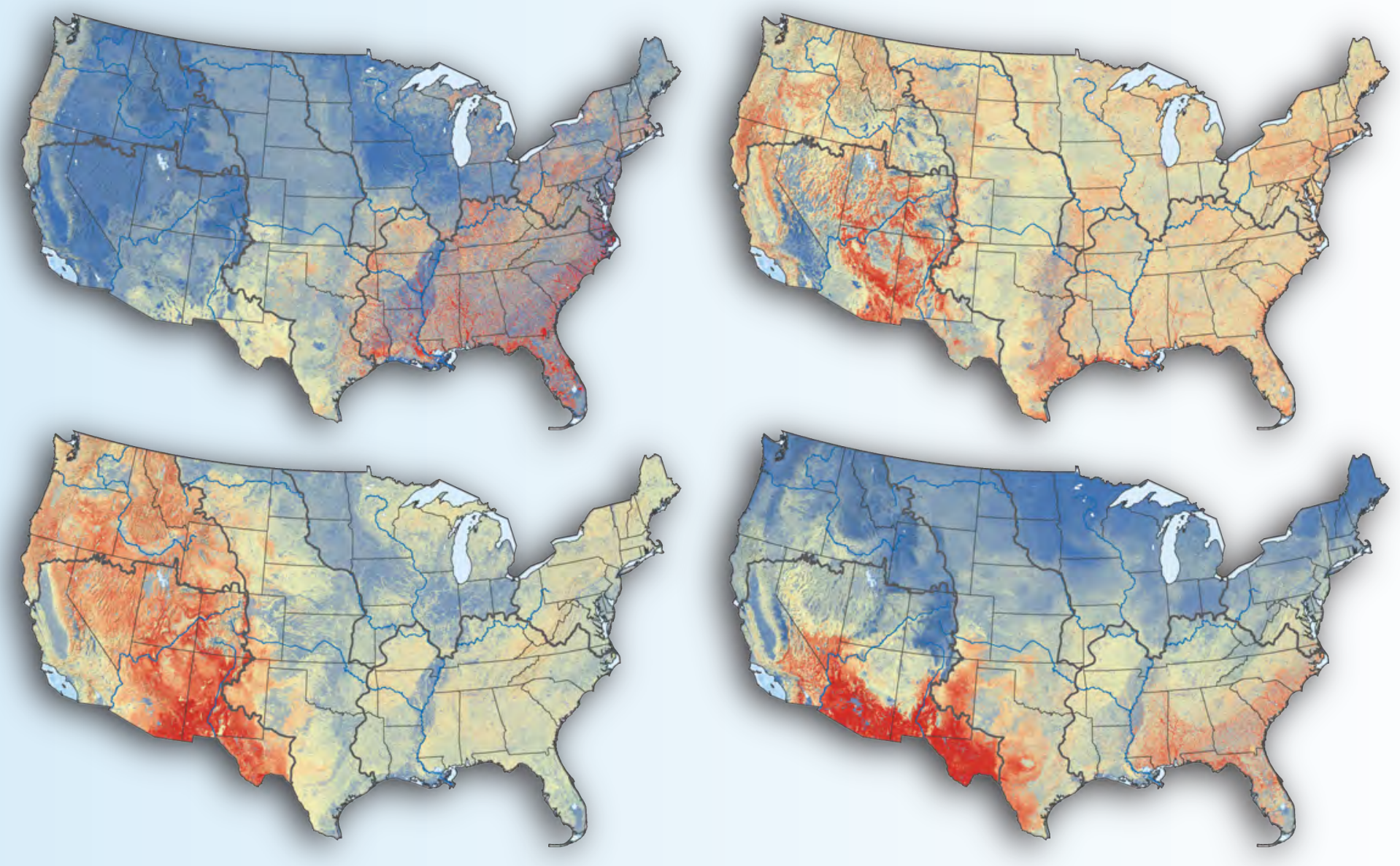

Scientific Investigations Report 2019-5034 
Cover. Mosaic of amphibian, bird, mammal, and reptile species richness maps derived from species' habitat distribution models of the conterminous United States. 


\section{Gap Analysis Project (GAP) Terrestrial Vertebrate Species Richness Maps for the Conterminous U.S.}

By Kevin J. Gergely, Kenneth G. Boykin, Alexa J. McKerrow, Matthew J. Rubino, Nathan M. Tarr, and Steven G. Williams

Prepared in cooperation with North Carolina State University, New Mexico State University, and Boise State University

Scientific Investigations Report 2019-5034 


\title{
U.S. Department of the Interior \\ DAVID BERNHARDT, Secretary
}

\author{
U.S. Geological Survey \\ James F. Reilly II, Director
}

U.S. Geological Survey, Reston, Virginia: 2019

For more information on the USGS - the Federal source for science about the Earth, its natural and living resources, natural hazards, and the environment-visit https://www.usgs.gov or call 1-888-ASK-USGS (1-888-275-8747).

For an overview of USGS information products, including maps, imagery, and publications,

visit https://store.usgs.gov.

Any use of trade, firm, or product names is for descriptive purposes only and does not imply endorsement by the U.S. Government.

Although this information product, for the most part, is in the public domain, it also may contain copyrighted materials as noted in the text. Permission to reproduce copyrighted items must be secured from the copyright owner.

Suggested citation:

Gergely, K.J., Boykin, K.G., McKerrow, A.J., Rubino, M.J., Tarr, N.M., and Williams, S.G., 2019, Gap Analysis Project (GAP) terrestrial vertebrate species richness maps for the conterminous U.S.: U.S. Geological Survey Scientific Investigations Report 2019-5034, 99 p., https://doi.org/10.3133/sir20195034.

ISSN 2328-0328 (online) 


\section{Contents}

Abstract

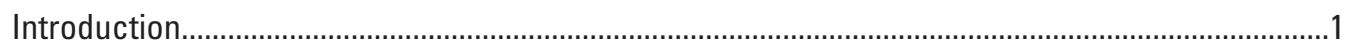

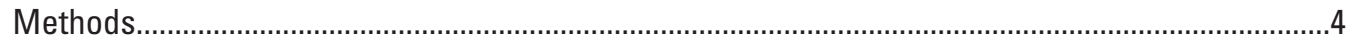

Species Habitat Distribution Modeling ................................................................................

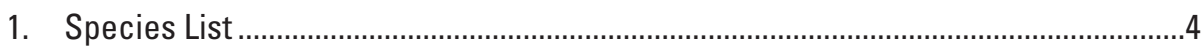

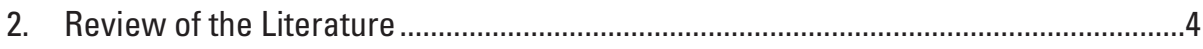

3. Compile a National Range Map ……………………...............................................

4. Enter Habitat Relationships into a Relational Database..............................................5

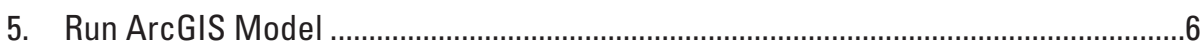

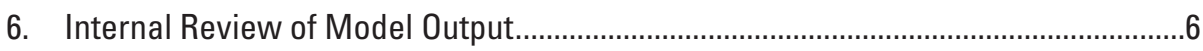

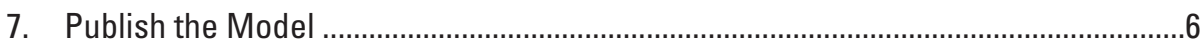

GAP Wildlife Habitat Relations Models (WHRMs) and Their Associated Habitat Maps Can be

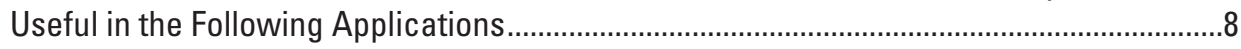

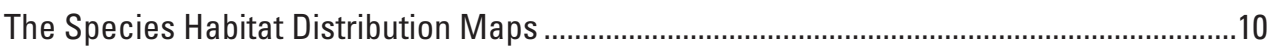

Other Literature Related to GAP Species Habitat Distribution Models ..................................10

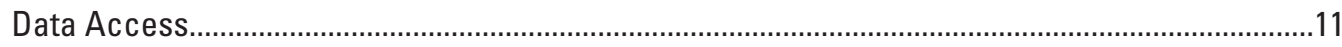

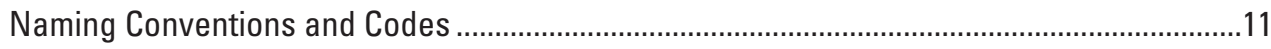

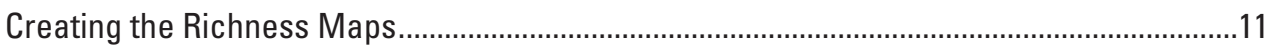

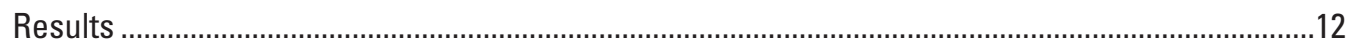

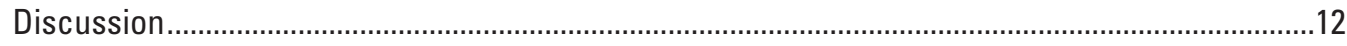

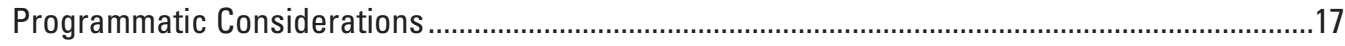

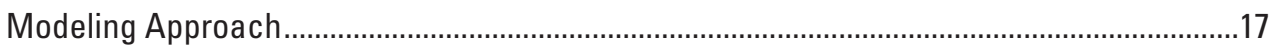

Model Review and Assessment..........................................................................................17

Comparing Models...........................................................................................................

Future Directions.............................................................................................................

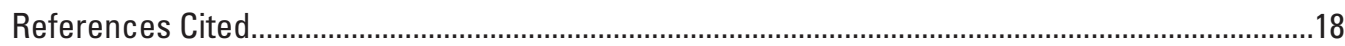

Appendix 1. Ancillary Datasets and Model Parameter Used in Species' Habitat Modeling.......22

Land Cover and Derivatives ...................................................................................................22

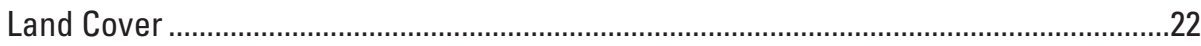

Patch Size

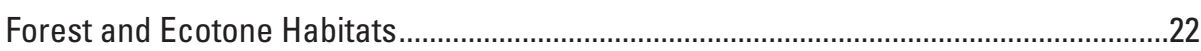

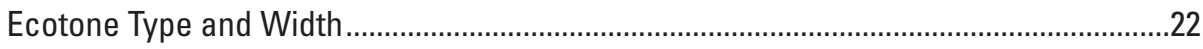

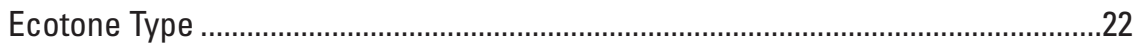

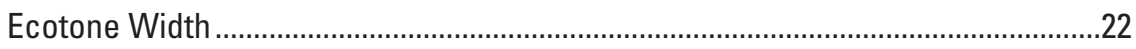

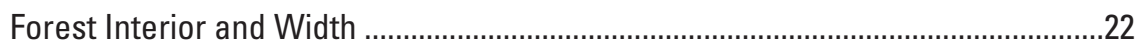

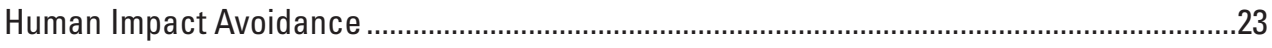

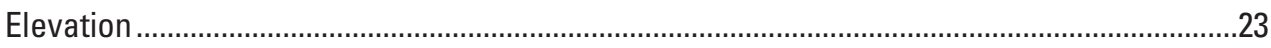

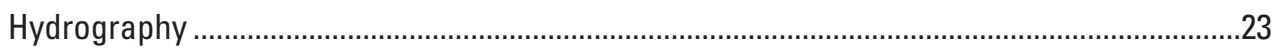

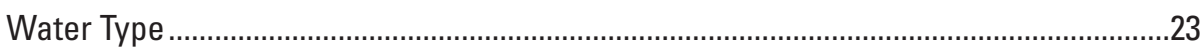

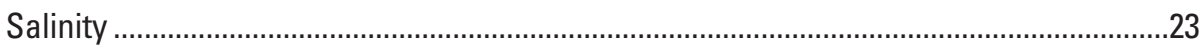

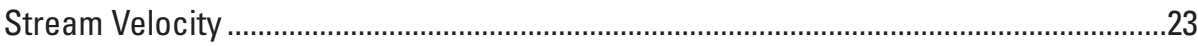

Appendix 2. Selected References for Information Used to Delineate Species' Ranges .............64

Appendix 3. Table of Notes on Species Taxonomy ……...........................................................79

Appendix 4. Table of Ancillary Datasets ..................................................................................99 


\section{Figures}

1. Map showing known range and predicted habitat distribution of Botaurus lentiginosus (American Bittern)

2. Map showing amphibian species richness derived from species habitat distribution models for the conterminous U.S.

3. Map showing bird species richness derived from species habitat distribution models for the conterminous U.S.

4. Map showing mammal species richness derived from species habitat distribution models for the conterminous U.S.

5. Map showing of reptile species richness derived from species habitat distribution models for the conterminous U.S

\section{Tables}

1.1. List of 1,590 species for which Gap Analysis Project (GAP) habitat distribution models were created and combined to generate maps of species richness maps by class (amphibia, bird, mammal, reptile).

2.1. List of 129 subspecies for which Gap Analysis Project (GAP) habitat distribution models were created class (amphibia, bird, mammal, reptile).

3.1. Notes on species taxonomy related to the Integrated Taxonomic Information System and NatureServe's Global Element Identifiers for species where there was not a direct match with the taxonomic concept being modeled by Gap Analysis Project (GAP)

4.1. Ancillary data used to create species' habitat maps and URLs to access those data through U.S. Geological Survey ScienceBase

\section{Conversion Factors}

U.S. customary units to International System of Units

\begin{tabular}{lcl}
\hline \multicolumn{1}{c}{ Multiply } & By & \multicolumn{1}{c}{ To obtain } \\
\hline acre & Area & \\
acre & 4,047 & square meter $\left(\mathrm{m}^{2}\right)$ \\
acre & 0.4047 & hectare $($ ha) \\
acre & 0.4047 & square hectometer $\left(\mathrm{hm}^{2}\right)$ \\
square mile $\left(\mathrm{mi}^{2}\right)$ & 0.004047 & square kilometer $\left(\mathrm{km}^{2}\right)$ \\
section $\left(640 \mathrm{acres}^{2}\right.$ or 1 square mile) & 259.0 & hectare (ha) \\
\hline
\end{tabular}




\section{Conversion Factors-Continued}

International System of Units to U.S. customary units

\begin{tabular}{lcl}
\hline \multicolumn{1}{c}{ Multiply } & By & \multicolumn{1}{c}{ To obtain } \\
\hline meter $(\mathrm{m})$ & 3.281 & foot $(\mathrm{ft})$ \\
\hline \multicolumn{2}{c}{ Area } & \\
\hline square meter $\left(\mathrm{m}^{2}\right)$ & 0.0002471 & acre \\
hectare (ha) & 2.471 & acre \\
square hectometer $\left(\mathrm{hm}^{2}\right)$ & 2.471 & acre \\
square kilometer $\left(\mathrm{km}^{2}\right)$ & 247.1 & acre \\
square meter $\left(\mathrm{m}^{2}\right)$ & 10.76 & square foot $\left(\mathrm{ft}^{2}\right)$ \\
square hectometer $\left(\mathrm{hm}^{2}\right)$ & 0.003861 & section $\left(640 \mathrm{acres}^{2}\right.$ or 1 square mile) \\
hectare (ha) & 0.003861 & square mile $\left(\mathrm{mi}^{2}\right)$ \\
\hline
\end{tabular}

\section{Datum}

Horizontal coordinate information is referenced to the North American Datum of 1983 (NAD 83), using the Geodetic Reference System 1980 (GRS 80).

Elevation, as used in this report, refers to distance above sea level.

\section{Supplemental Information}

Note to USGS users: Use of hectare (ha) as an alternative name for square hectometer $\left(\mathrm{hm}^{2}\right)$ is restricted to the measurement of small land or water areas. 



\title{
Gap Analysis Project (GAP) Terrestrial Vertebrate Species Richness Maps for the Conterminous U.S.
}

\author{
Kevin J. Gergely, ${ }^{1}$ Kenneth G. Boykin, ${ }^{2}$ Alexa J. McKerrow, ${ }^{1}$ Matthew J. Rubino, ${ }^{3}$ Nathan M. Tarr, ${ }^{3}$ and \\ Steven G. Williams ${ }^{3}$
}

\section{Abstract}

The mission of the Gap Analysis Project (GAP) is to support national and regional assessments of the conservation status of vertebrate species and plant communities. This report explains conterminous United States species richness maps created by the U.S. Geological Survey for four major classes in the phylum Chordata: mammals, birds, reptiles, and amphibians. In this work, we focus on terrestrial vertebrate species and the spatial patterns of richness derived from species' habitat distribution models. We created species' habitat distribution models for 1,590 species (282 amphibians, 621 birds, 365 mammals, 322 reptiles) and an additional 129 subspecies (2 amphibians, 28 birds, 94 mammals, 5 reptiles) that occur in the conterminous United States. The 1,590 species level models were spatially combined to create the taxa richness maps at a spatial resolution of 30 meters.

Based on those maps we identified the maximum species richness for each of the taxa (43 amphibians, 163 birds, 72 mammals, and 54 reptiles) and show variation in richness across the conterminous United States. Because these habitat models remove unsuitable areas within the range of the species, the patterns of richness presented here are different from the coarse-resolution species' habitat distribution models commonly presented in the literature. These maps provide a new, more spatially refined richness map. In addition, since these models are logically linked to mapped data layers that constitute habitat suitability, this suite of data can provide an intuitive data system for further exploration of biodiversity and implications for change at ecosystem and landscape scales.

\footnotetext{
${ }^{1}$ U.S. Geological Survey.

${ }^{2}$ New Mexico State University, Department of Fish, Wildlife and Conservation Ecology, Las Cruces, N. Mex.

${ }^{3}$ North Carolina State University, Department of Applied Ecology, Raleigh, N.C.
}

\section{Introduction}

A simple definition of biodiversity is the variety of life on the planet (Ryan, 1992). Historically, many United States' (U.S.) agencies have worked to maintain biodiversity through habitat improvement activities related to specific wildlife population goals. Maintaining biodiversity has been established as a socially accepted goal through legislation such as the Endangered Species Act (ESA; 16 U.S.C. § 1531 et seq.) that maintains biodiversity by protecting species that are moving towards extinction. Focus of the Gap Analysis Project (GAP) is broad and includes all terrestrial vertebrates in the U.S. that occupy habitat in summer, winter, or year-round. Through this effort the U.S. Geological Survey (USGS) contributes a biodiversity measure to the other major Earth science datasets developed by the USGS, such as those for hydrography and geology.

Specifically, the mission of the GAP is

To provide state, regional, and national biodiversity assessments of the conservation status of native vertebrate species, aquatic species, and natural land cover types and to facilitate the application of this information to land management activities. Species and habitat distribution models are used to conduct a biodiversity assessment for species across the U.S. The goal of GAP is to keep common species common by identifying species and plant communities that are not adequately represented in the existing conservation lands network. By providing these data, land managers and policy makers can make better-informed decisions when identifying priority areas for conservation (https://gapanalysis.usgs.gov/ about-gap/mission/).

GAP data are used to assess the status of biodiversity in the U.S. by mapping where species' habitats exist and to evaluate the likelihood of persistence of those habitats. The most common analysis is to perform a "gap analysis" or to evaluate where the system of protected areas in the U.S. provides inadequate habitat coverage for a species or group of species. Vertebrate diversity has been the ongoing focus of analysis for GAP, with the assumption that, although lacking sufficient 
data, vertebrates and their associated habitats are a reasonable measure of biodiversity because these species are responding to landscape level variation in vegetation and environmental conditions at a resolution that is meaningful for management and can serve as a coarse-filter for conservation planning (Noss and Cooperrider, 1994; Csuti and Kiester, 1996).

A goal of the USGS, in accordance with the GAP mission statement, is to create an objective biodiversity metric based on standardized data for the entire U.S. In support of that goal we have created habitat models for 1,590 species (appendix 1, table 1.1) and an additional 129 subspecies (appendix 2, table 2.1). In the richness maps presented here, the 1,590 species level models were used (without adding the 129 subspecies) as they include the modeled habitat for the subspecies. Consistent modeling methods across space and for all species being considered are desirable for an objective metric to be comparable across various scales of ecological organization, from small patches to vast landscapes. (Rahbek, 2005; Hurlbert and Jetz, 2007). Given differential data availability for many species over large extents we relied on deductive habitat suitability modeling methodology for this effort. This approach achieves a quantitative metric for biodiversity and forms the basis for analysis and understanding thatn can be expanded with time.

Mapped data on species' ranges are often used to inform patterns of biodiversity and aid in planning for conservation delivery. (Jenkins and others, 2015). Range data are available for most species across the U.S. but often have limitations including lack of precision, incompleteness and lack of robust statistical validation (Di Marco and others, 2017; Rondinini and others, 2011). Analyses based on a species’ range can additionally be limited by using ranges that are inclusive of areas not considered potential habitat (Hurlbert and White, 2005). For example, including agricultural lands within the range for a forest dwelling species. Species distribution modeling applications use spatial information on habitat variables to predict potential habitat distributions (Ficetola and others, 2015; Buchanan and others, 2011; Rondinini and others, 2011), rather than to predict spatial occupancy of species based on known occurrence points. The species and the quality and quantity of available data will dictate the best modelling approach. Deductive modeling of potential habitat can be the most practical and management- relevant approach when data are limited (Aycrigg and others; 2015, Rondinini and others, 2011) or insufficient for statistical occurrence models (Van Horne, 2002). Modelling patterns of biodiversity over very large regions (for example, landscapes to continents) and for a large number of species will undoubtedly include sparse and inconsistent data which makes deductive models the most pragmatic approach (Rondinini, 2011).

Here we explain the process used by the USGS to create the species richness maps for four major classes in the phylum Chordata: mammals, birds, reptiles, and amphibians for the conterminous U.S. This work was accomplished by a team of biologists from the USGS and partner institutions (Boise State University, North Carolina State University, and New Mexico State University). These richness maps (figs. 2-5) were created using deductive species' habitat distribution modeling methods described below. Those models were formally released in July 2018 and are described and made available through the USGS's data repository ScienceBase (https://doi. org/10.5066/F7V122T2).

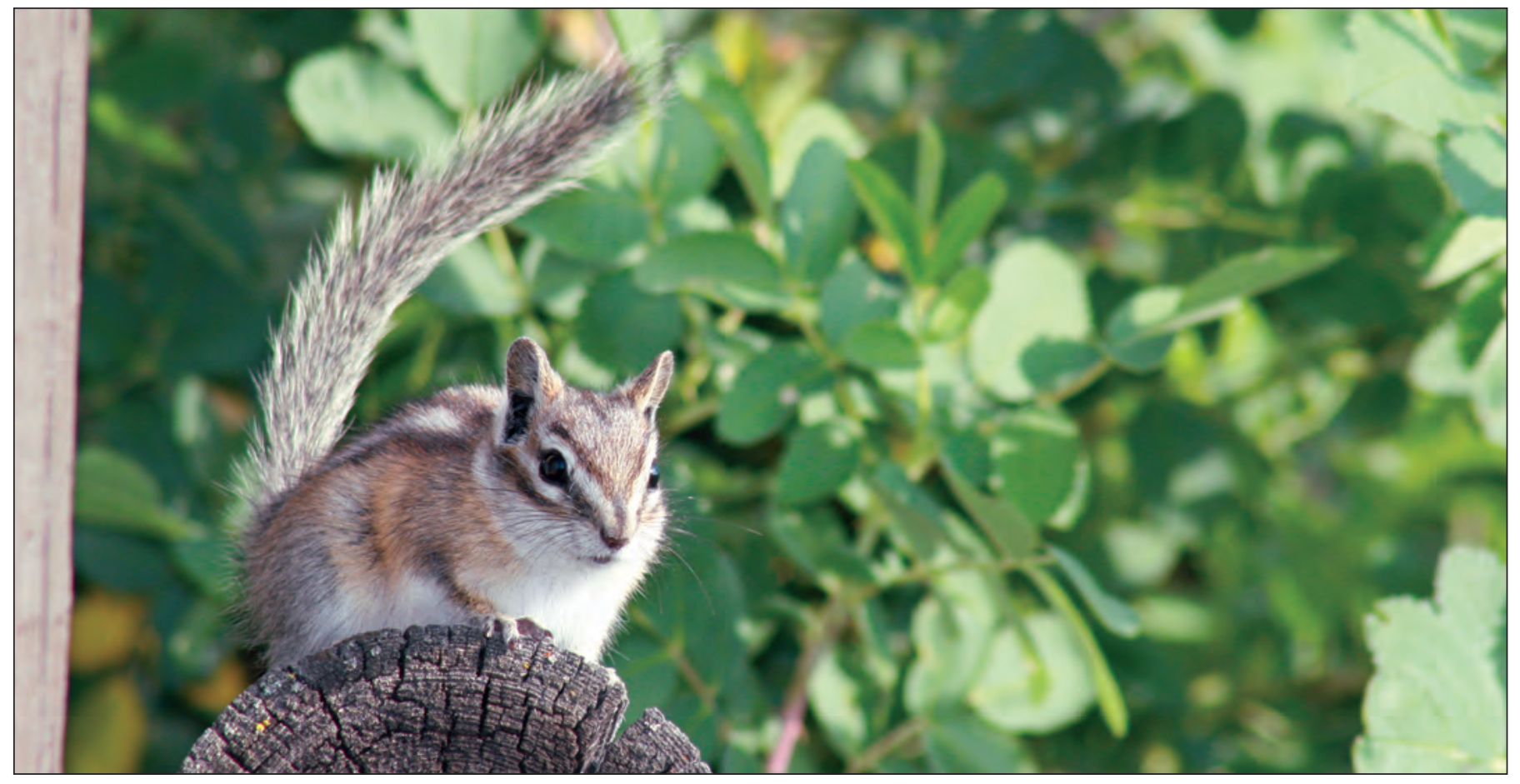

Photograph of a Tamias minimus (Least Chipmunk) on a log in Grand Teton National Park, Wyoming, by John J. Mosesso, January 28, 2014. Accessed Oct. 4, 2018, at https://commons.wikimedia.org/wiki/File:Least_Chipmunk_(12188508453).jpg. 


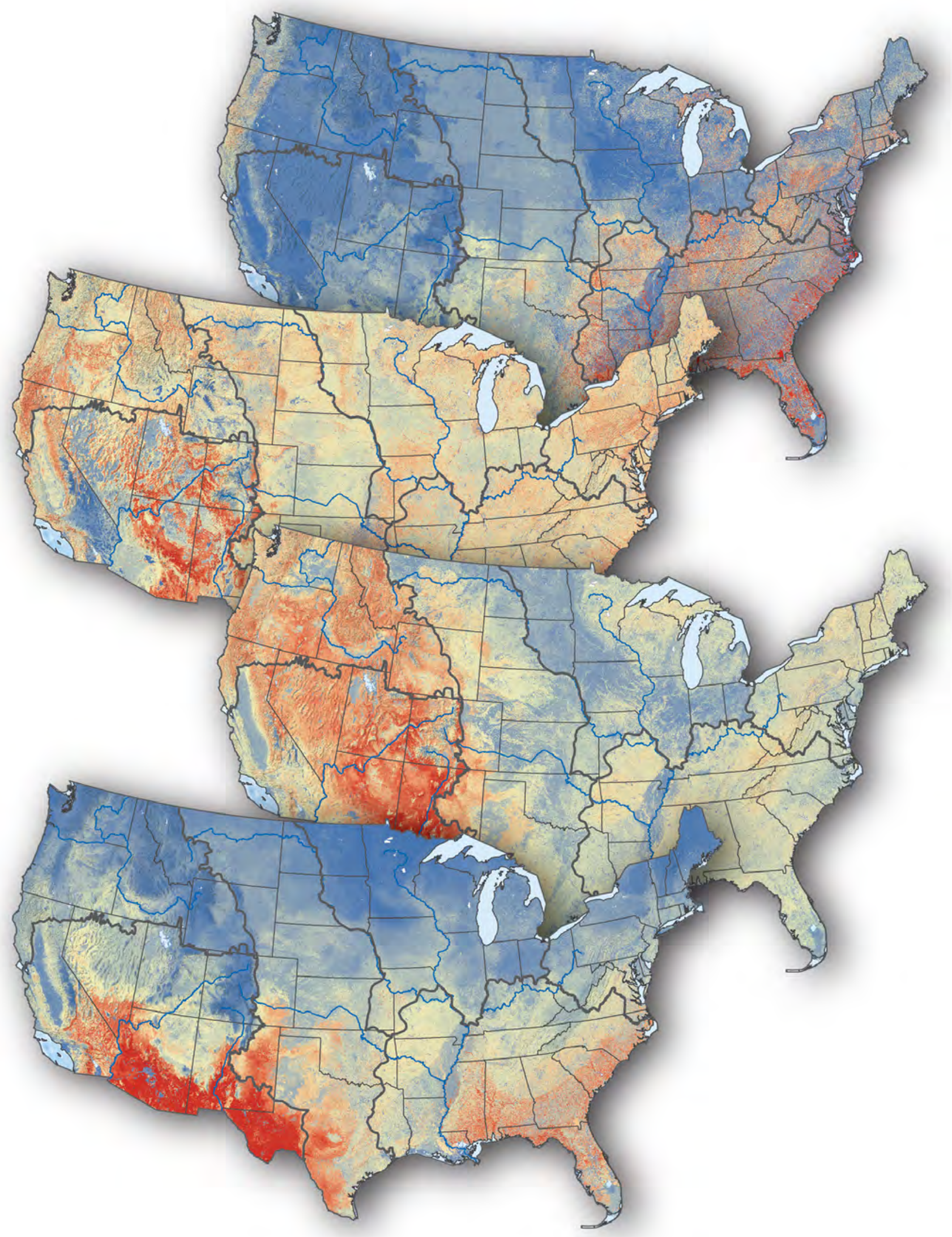

Mosaic of figures 2-5, amphibian, bird, mammal, and reptile species richness maps derived from species' habitat distribution models of the conterminous United States. 


\section{Methods}

\section{Species Habitat Distribution Modeling}

To create species richness maps based on GAP habitat maps, we initially created individual species' ranges and habitat distribution models for each of the terrestrial vertebrate species found in the conterminous U.S. during summer, winter, or year-round (both summer and winter). We did not attempt to model stopover habitats (areas visited briefly for rest or foraging) for migratory species. The habitat distribution modeling process involves seven steps detailed below.

\section{Species List}

We started with a species list for each of the four terrestrial vertebrate classes of interest (that is, mammals, amphibians, reptiles, birds). The final combined list was compiled from three standard checklists including:

Banks, R.C., Chesser, R.T., Cicero, C., Dunn, J.L., Kratter, A.W., Lovette, I.J., Rasmussen, P.C., Remsen, J.V., Jr., Rising, J.D., Stotz, D.F., and Winker, K., 2008, Forty-ninth supplement to the American Ornithologists Union checklist of North American birds: The Auk, v. 125, issue 3, p. 758-768. [Also available at https://doi.org/10.1525/ auk.2008.9708.]

Crother, B.I., committee chair, 2008, Scientific and standard English names of amphibians and reptiles of North America north of Mexico, with comments regarding confidence in our understanding (6th ed.): Society for the Study of Amphibians and Reptiles, Herpetological Circular no. 37, $94 \mathrm{p}$.

Wilson, D.E., and Reeder, D.M., eds., 2005, Mammal species of the world-A taxonomic and geographic reference (3d ed.): Baltimore, Johns Hopkins University Press, 2,000 p.

\section{Review of the Literature}

For each species and subspecies, common references (listed below) were consulted to obtain taxonomy, range extent, characteristics of habitats used by the species, and life history information. For taxa less represented in these common references, a refined literature search was used to provide complete information. For species with sufficient information related to subspecies' ranges, a determination was made as to whether subspecies level range and model development was necessary. Specifically, we asked: "Were the ranges between subspecies spatially distinct and were there unique habitat relationships that warranted a separate subspecies model?”

Given that species information was created over time and was inclusive of more than 1,700 species and subspecies, it is possible that more recent publications have not yet been added to a reference list. The compendium of species literature was developed for the primary purpose of documenting the species' range and their habitat preferences, therefore, omission of more recent references is unlikely to significantly change the results of this project. The literature provided is not offered as a definitive list of references for the species, but in most cases, is fairly complete. For each species modeled, we included the Integrated Taxonomic Information System Taxonomic Serial Number and NatureServe's Global Element Identifier that reflects the most precise taxonomic concept match. See table 3.1 (appendix 3) for notes on species where the name or taxonomic concepts were not a direct match.

List of common references consulted:

- American Society of Mammalogists' species accounts, accessed 10 12, 2016, at http://www.mammalsociety. org,

- California wildlife habitat relationships database accessed 10 12, 2016, at https://www.wildlife.ca.gov/ Data/CWHR,

- Lanoo, M., ed., 2005, Amphibian declines-The conservation status of United States species: Berkeley and Los Angeles, University of California Press, 1,115 p.

- NatureServe Explorer, accessed 10 12, 2016 at http:// explorer.natureserve.org/,

- The Cornell Lab of Ornithology, Birds of North America: Ithaca, N.Y., Cornell University, accessed 10,12,2016, at https://birdsna.org/Species-Account/ bna/home.

\section{Compile a National Range Map}

GAP species range data are coarse representations of the geographic limits within which a species can be found (Morrison and Hall, 2002). Range maps provide the geographic extent that the USGS GAP uses to delineate areas of suitable habitat for terrestrial vertebrate species to produce habitat maps. The range maps are created by attributing a vector file derived from the 12-digit Hydrologic Unit Dataset (USGS and U.S. Department of Agriculture [USDA], Natural Resources Conservation Service, 2009]). Modifications to that dataset are described in the ScienceBase item https:// doi.org/10.5066/F7DZ0754 (USGS, 2011). Attribution of the season range for each species was based on the literature and online sources (See McKerrow and others, 2018, their appendix 2 (see supporting information at https://doi.org/10.1111/ ddi.12779). In addition to published ranges, online species occurrence databases were also consulted (for example, Global Biodiversity Information Facility [GBIF]). Range delineations can best be described as a synthesis of data. They were derived from existing range information, not from a primary analysis of occurrence points. Our synthesis was aimed at defining a 
range based on existing data sources and standardizing the data at a resolution that made analysis with other data sets possible. Actual recorded occurrences were used to develop the ranges when those occurrence points provided additional or confirmatory information.

Attribution for each hydrologic unit within the range included values for origin (native, introduced, reintroduced, or vagrant), occurrence (extant, possibly present, potentially present, or extirpated), reproductive use (breeding, nonbreeding, or both) and season (year-round, summer, winter, migratory, or vagrant). These species' range data provide the biological context within which to build our species' distribution models.

\section{Enter Habitat Relationships into a Relational Database.}

GAP habitat maps were created by applying a deductive habitat model, the Wildlife Habitat Relations Model (WHRM), to remotely-sensed data layers within a species' range. The deductive habitat models were built by compiling information on species' habitat associations and entering it into a relational database. Information was compiled from the best available characterizations of species' habitat at the time the modeling information was collected. As noted above, the list of sources was not intended to be a complete reference list. Sources included species' accounts in books, databases, and peer-reviewed literature. The literature references for each species are included in the "Species Habitat Model Report" and "Machine Readable Habitat Database Parameters" files attached to each habitat map item in ScienceBase (see the "Data Access" section of this report for details). For all species, the compiled habitat information is used by a scientist to determine which of the ecological systems and land use classes represented in the National GAP Land Cover Map ver. 1.0 (https://doi.org/10.5066/F7959GF5) is associated with that species.

USGS GAP land cover data used in the habitat modeling for this report were a seamless 30-meter $(\mathrm{m})$ resolution, thematically detailed ( $>580$ classes) land cover map with a specific focus on vegetation and land use types relevant to terrestrial species habitats. The USGS GAP Land Cover Map used vegetation classes based on NatureServe's Ecological Systems Classification (Comer and others, 2003) and land cover classes described in the National Land Cover Dataset (Homer and others, 2007). These data described vegetation communities at a level of thematic detail useful for ascribing habitat types for species because it was based on dominant vegetation and was discernible from remotely- sensed data or from plot-based modeling. Prior to the development of this dataset this level of detail had not been available for a map of the U.S. The detailed land cover data reflect regional variation and provide an ecological context related to plant species composition and structure, as well as climatic regimes; all these are important for describing habitats of different species. For example, in the southeastern U.S., map units such as "East Gulf Coastal Plain Interior Upland Pine Woodland" and "Southern Coastal Plain Blackwater River Floodplain Forests" provide meaningful context. Similarly, in the northwest U.S., detailed descriptions for the map classes such as "Northern Rocky Mountain Mesic Montane Mixed Conifer Forest” and "Northern Rocky Mountain Montane-Foothill Deciduous Shrubland" indicate important plant habitat composition and structure that inform what animal species are likely to be present.

For many species, factors other than land cover were used to define a suitable environment o were included in the database. These factors included elevation (that is minimum, maximum), proximity to water features, proximity to wetlands, level of human development, forest ecotone width, and forest edge. Each factor corresponded to a data layer that was used during map production. For a list of the ancillary datasets and descriptions of the parameters used see table 4.1 in appendix 4. The specific parameters used in the modeling and mapping process are documented in the "Species Habitat Model Report" and "Machine Readable Habitat Database Parameters" files and included with the final models in the ScienceBase repository (see the "Data Access" section of this report).

The final habitat maps are generated using a Python script that queries the model parameters in the database; reclassifies the GAP Land Cover ver 1.0 and ancillary data layers within the species' range and combines the reclassified layers to produce the final 30-m resolution habitat map. These habitat maps reflect ecological systems, and all other constraints applied within habitat models that are represented by the ancillary data layers. Six regions were used to simplify habitat modeling within the conterminous U.S.: Northwest, Southwest, Great Plains, Upper Midwest, Southeast, and Northeast (see U.S. Geological Survey, 2011). These regions allowed for efficient processing of the species distribution models on smaller, ecologically homogenous extents.

Habitat affinities were assigned based on the literature accounts for each species to indicate whether a species would occupy (or not) a particular map class in a given season. The three values used and their associated definitions for the National Gap Analysis Project’s Habitat Maps are:

Value 1 = Known or probable occurrence, summer;

Value 2 = Known or probable occurrence, winter;

Value 3 = Known or probable occurrence, year-round (both winter and summer). 


\section{Run ArcGIS Model}

After the database was populated, a spatial model was designed using a Python script to access information within the database, select map units (land cover classes or ecological systems) and ancillary criteria, and ultimately apply selection to spatial datasets limited to the species' range. A raster data set in GeoTIFF file format was the output for each modeling region, and region outputs were mosaicked to create the national extent raster for each species.

\section{Internal Review of Model Output}

The habitat distribution map for each species was reviewed first by the scientist that developed the model, and then by a second biologist before being finalized. Edits based on the reviews were incorporated into the database and the script was rerun to generate the final map. The name of the biologist who carried out the literature review and assembled the modeling parameters is shown as the "editor" type contact for each habitat map item in the ScienceBase repository (USGS, 2018a).

\section{Publish the Model}

The final model and range map were then published and made available online through ScienceBase at https://doi. org/10.5066/F7V122T2 (USGS, 2018a). Publication involved generating a species-specific metadata report, the attributed vector file for the species range, and the final habitat distribution map (that is, a $30 \mathrm{~m}$ resolution raster with a value between 1 and 3 representing suitable habitat) (fig. 1).

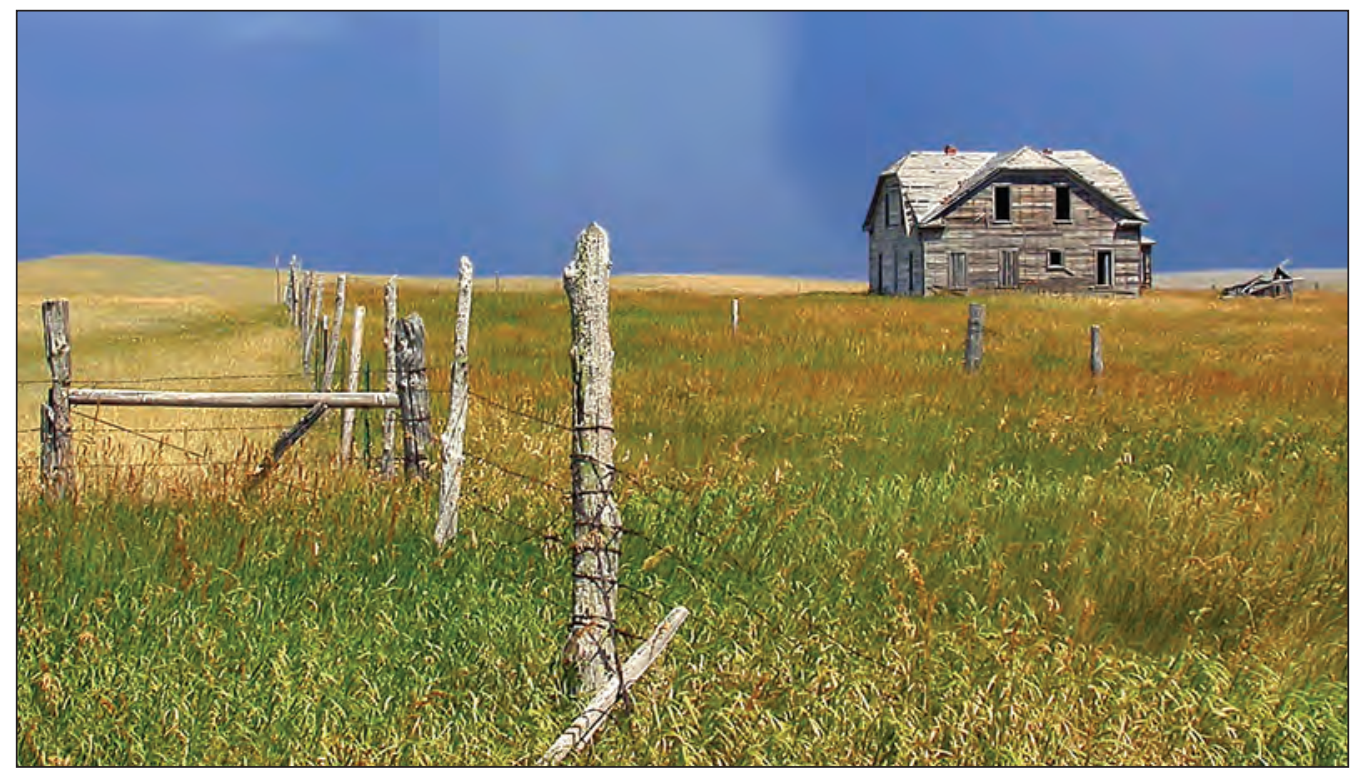

An agricultural field in the Great Plains region of Montana, by Terry Sohl, U.S. Geological Survey, September 2015. Accessed 0ct. 5, 2018, at https://www.usgs.gov/media/ images/agricultural-field-greatplains-region-montana.
Coastal and near shore environments. A salt marsh near Homosassa Springs, Florida. Photograph by Randolf Femmer, U.S. Geological Survey, May 1996. Accessed on 0ct. 5, 2018 at https:// www.usgs.gov/media/images/saltmarsh-near-homosassa-springs.

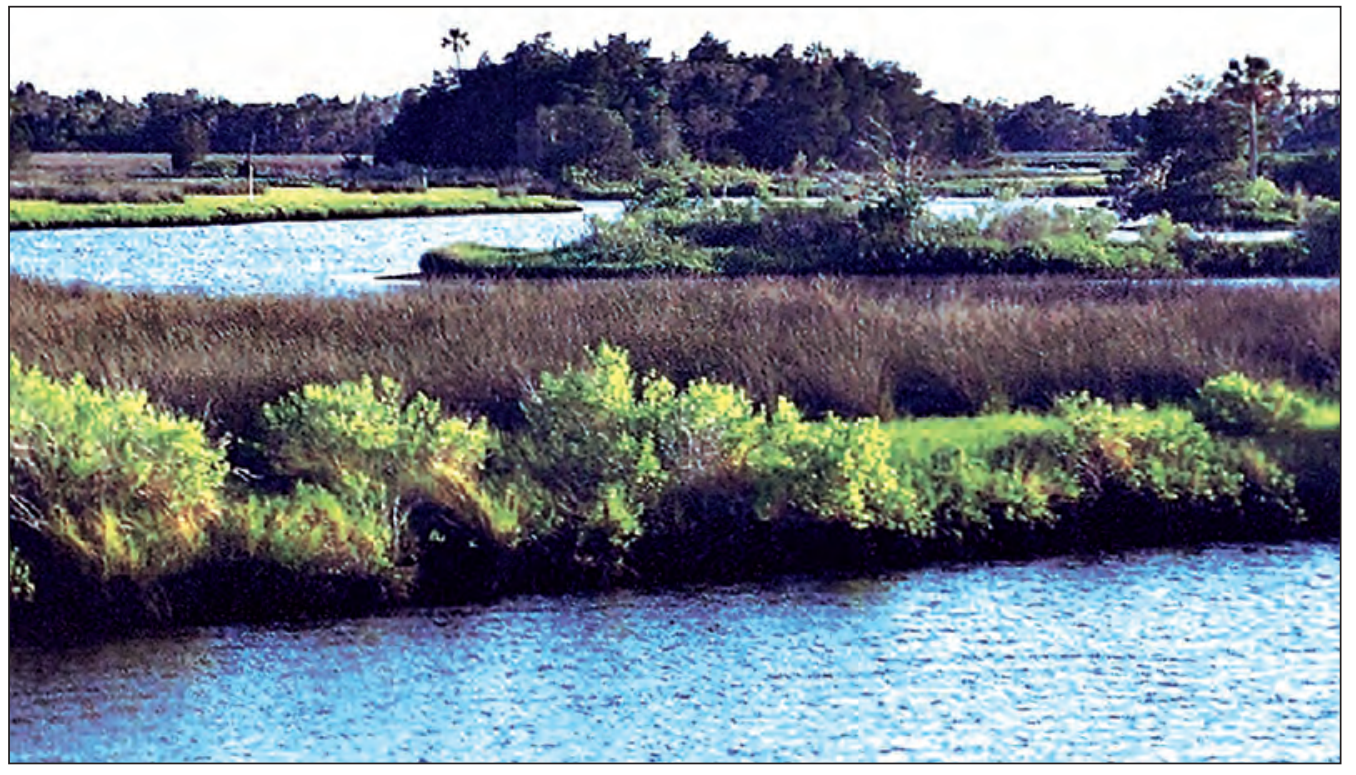




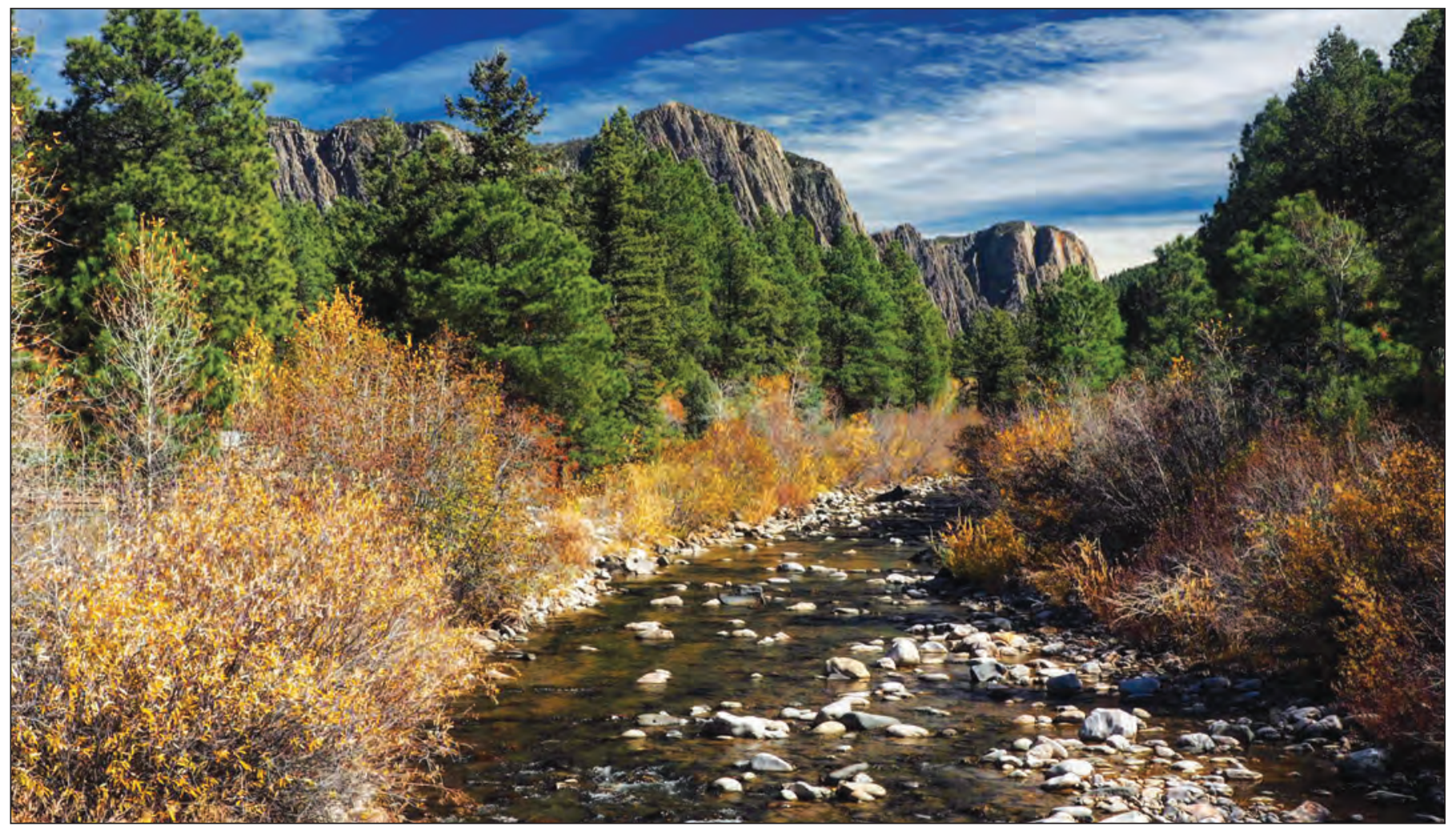

An example of coniferous forests and riparian habitat by the Rio Brazos near Tierra Amarilla, New Mexico, by Lindsay Hastings, 0ct. 17, 2016. Accessed 0ct 5, 2018, at https://www.usgs.gov/media/images/rio-brazos-near-tierra-amarilla-nm.

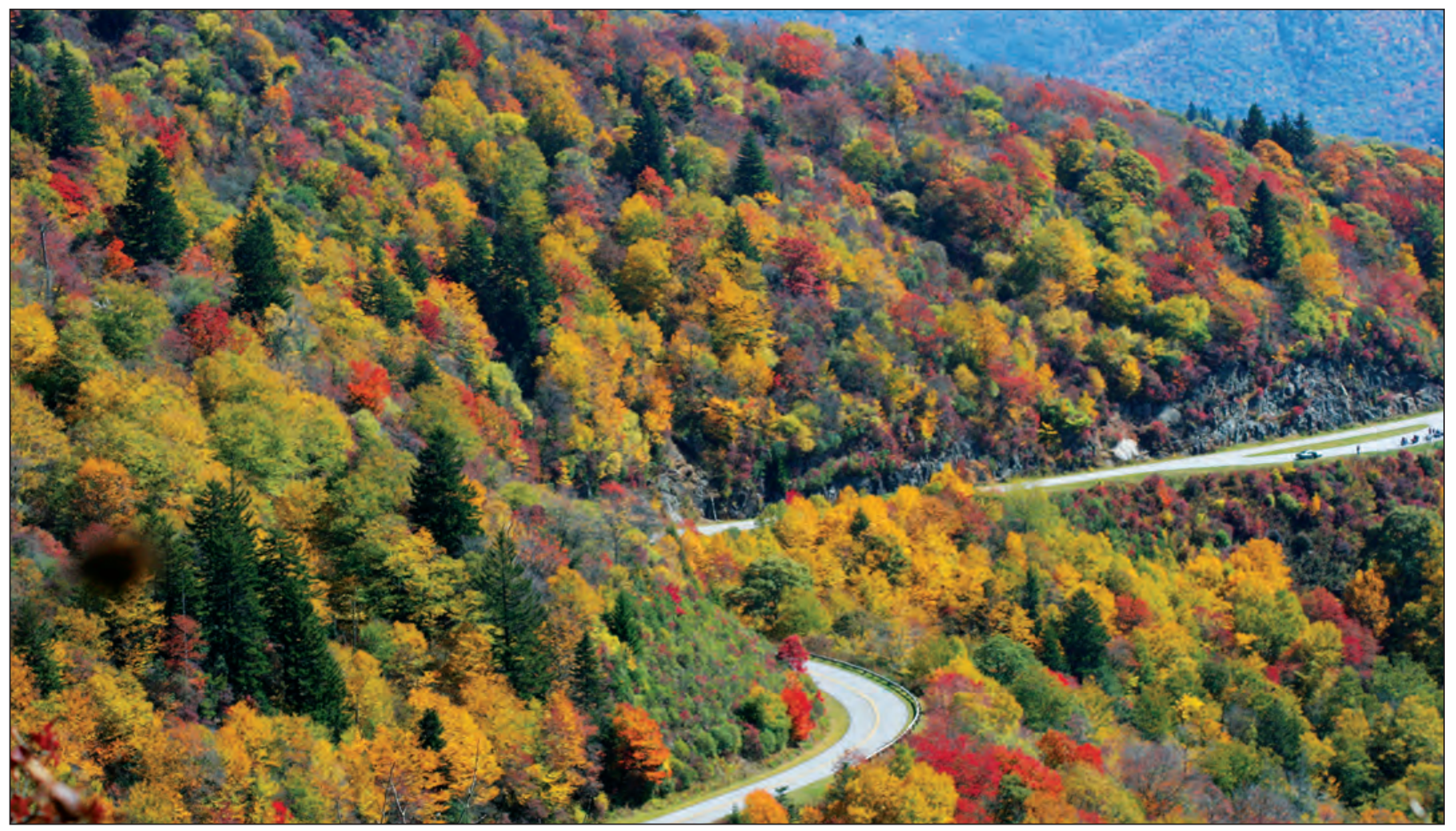

An example of eastern deciduous forests with fall foliage in North Carolina, as viewed from Waterrock Knob with the Blue Ridge Parkway winding below, by Tanya Schoenhoff, U.S. Geological Survey, Oct. 11, 2008. Accessed Oct. 4, 2018 at https://www.usgs.gov/media/images/blue-ridge-parkway-fall-foliage-0. 


\section{GAP Wildlife Habitat Relations Models (WHRMs) and Their Associated Habitat Maps Can be Useful in the Following Applications}

- Conservation planning and spatial conservation prioritization at regional and national extents (that is, complementarity, redundancy, representation; Scott and others, 1993), including climate adaptation (Groves and others, 2012).

- Mapping alpha, beta, and gamma species diversity, and evaluating the spatial coincidence of biodiversity hotspots among taxa and groups of species (Scott and others, 1993).

- Assessing multi-species habitat conservation (Scott and others, 1993, Probst and Gustafson 2009).

- Removing areas of unsuitable land cover from predictive species occurrence maps created with external data-driven species distribution models that make predictions based upon climatic and geophysical variables (Scott and others, 1993).

- Using biogeography to guide and provide context for inquiries into species at risk or benefit from mappable land cover changes with regions of interest (for example, urbanization and climate refugia, respectively).
- Translating historic or projected changes in landscapes into changes in mesoscale habitat availability (for example, fire, urbanization, and clearcutting).

- Linking coarse and fine resolution species habitat data to design wildlife surveys in support of species-specific landscape analyses (Probst and Gustafson, 2009).

- Characterizing landscapes around points or small areas to create landscape variables for multi-scale, spatiallyexplicit population and species distribution models.

- Filtering multi-scale, multi-species wildlife data at a broad scale for conservation assessments and planning (Probst and Gustafson, 2009). Identifying places of interest for wildlife observation and study, and stratifying effort in wildlife surveys (Scott and others, 1993).

- Testing the performance of indicator species in representing multiple species in habitat protection assessments (Scott and others, 1993).

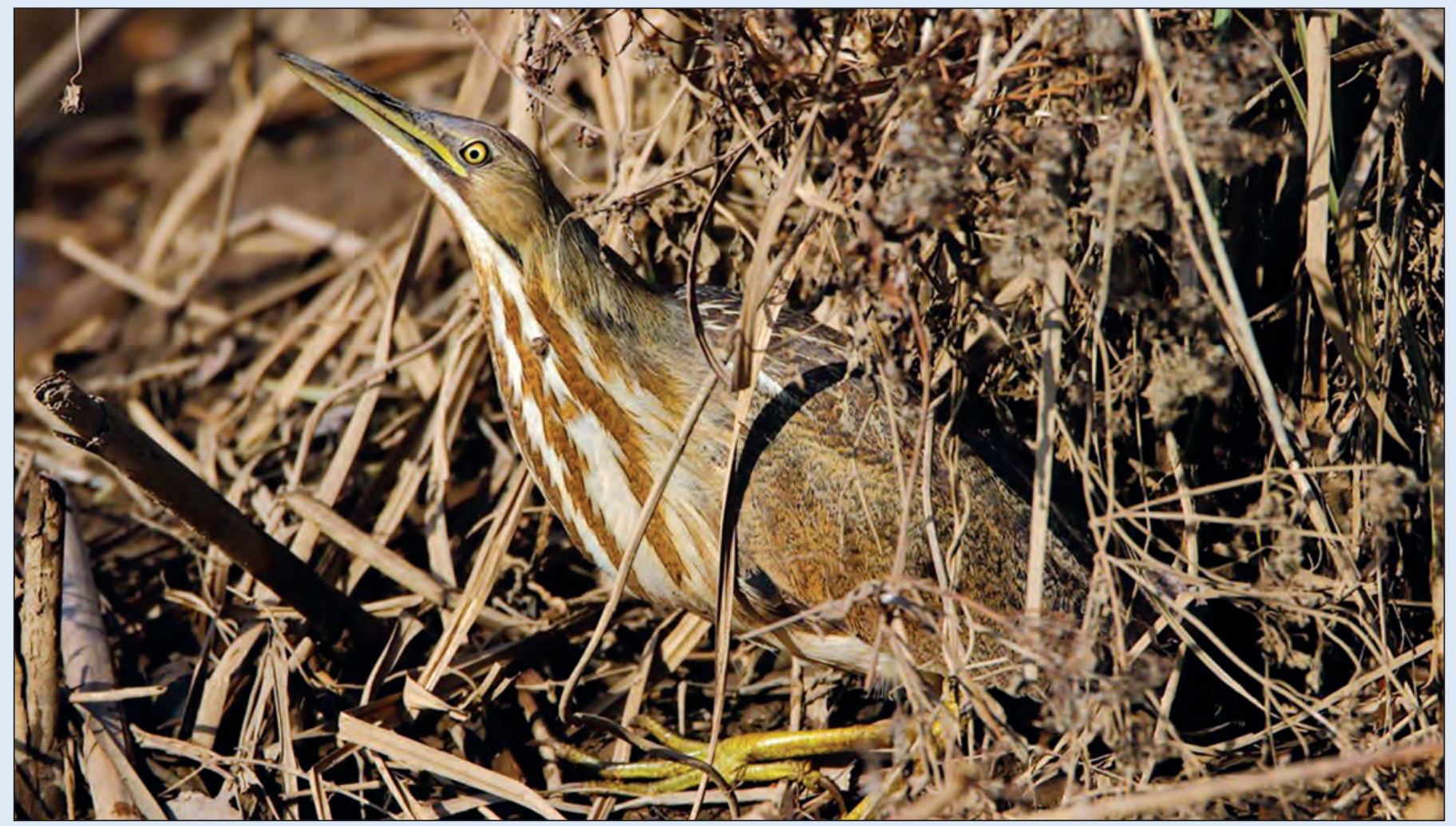

Photograph of a Botaurus lentiginosus (American Bittern) in Kenilworth Marsh, Washington, D.C., by J. Read, National Park Service. Accessed Oct. 4, 2018, at https://www.nps.gov/keaq/planyourvisit/birding.htm. 


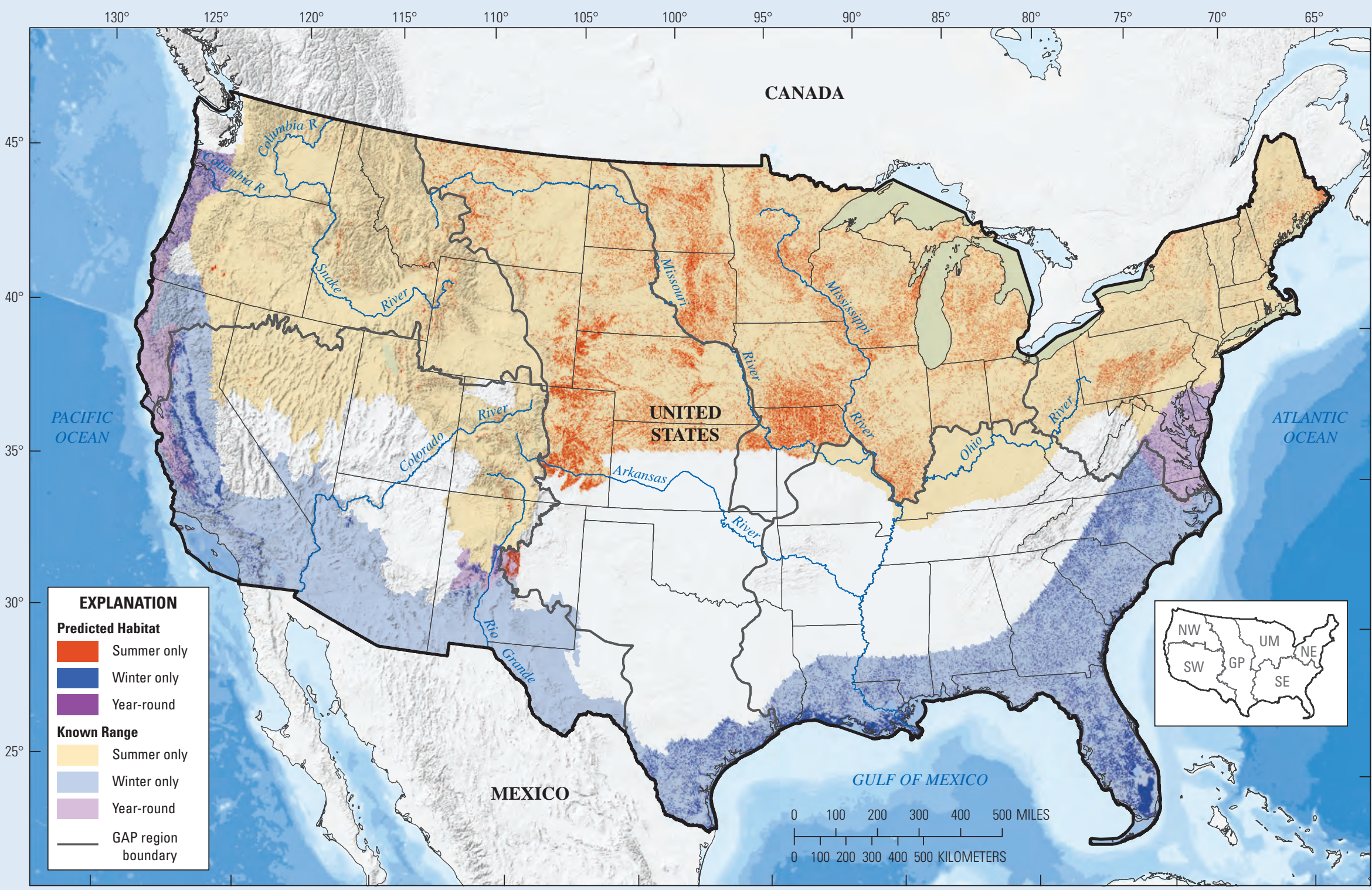

Base from U.S. Geological Survey digital data, The National Map,

accessed December 2018, at https://viewer.nationalmap gov/basic

Albers Equal-Area Conic projection, North American Datum of 1983

Figure 1. Map of known range and predicted habitat distribution of Botaurus lentiginosus (American Bittern). In the foreground the predicted habitat for the species is shown. The lighter colors in the background show the range used to constrain the predicted habitiat distribution model. Gap Analysis Project (GAP) region boundaries used in the modeling effort: NW, northwest; SW, southwest; GP, Great Plains; UM, Upper Midwest; SE, southeast; NE, northeast. 


\section{The Species Habitat Distribution Maps}

GAP habitat maps are representations of the spatial distributions of suitable environmental and land cover conditions for individual species within the U.S. Specifically, these maps show places within a species' range where the environment is predicted to be suitable for the species to occur, while areas not included in the map are those predicted to be unsuitable for the species to occur. Multiple maps may exist for species that migrate within the conterminous U.S. during the year and species with habitat associations that vary with season, or reproductive period.

GAP habitat maps are created by intersecting coarse resolution range maps with maps created with moderate-resolution wildlife habitat relationship models (WHRMs). The resulting maps have significantly more detail than range maps, but less detail than microhabitat models that would incorporate information on features within broad classes of floral composition (for example, cavity trees, rock outcrops, and small ponds) that are not currently mapped at large extents. The maps are appropriate for application at a 1:100,000- scale (Morrison and others, 2006). The 2001 National Land Cover dataset (NCLD, 2001; Homer and others, 2007), which underlies most of our species' models and defines their ecological scale, has a minimum mapping unit of 1 acre, but habitat definitions within the WHRMs are often further refined with data layers, such as elevation or hydrography layers, that may identify 900 square meter $\left(\mathrm{m}^{2}\right)$ patches of mesoscale habitat.

GAP habitat maps do not explicitly predict occurrence of each species at any given time, because species' actual (fine-scale) distributions can vary due to intra- and interspecific interactions and population dynamics that can leave suitable habitat unoccupied (Pulliam, 2000). Fine-scale habitat characteristics that are not well represented by the WHRMs can further restrict the distribution of individuals among locations. Conversely, habitat maps do predict species absence at this scale (Johnson and others, 2009); that is, if habitat is well understood and parametrized well in a model. These maps are valuable for several reasons: (1) the detail and resolution of the maps match the perspective often used for conservation implementation and land-use planning, and corresponds to changes in land cover (Scott and others, 1993; Ferrier and others, 2004; Flather and others, 2009, Johnson and others, 2009); (2), these maps provide a relatively quick and inexpensive assessment of the distribution of vegetation and associated species (Scott and others, 1993). By leveraging remotelysensed data, WHRMs avoid depending upon expensive and inefficient data collection in the field. By excluding unsuitable areas, WHRMs produce maps that can be used for broad-scale applications compared to range maps alone; and (3), these maps provide a medium resolution characterization of the extent of habitat of a species. Similarly, the maps can suggest unsurveyed areas where species may occur now or after range shifts. Finally, the completeness of the GAP WHRM dataset enables analyses and assessments of all species or customized groups of species as well as analyses at national, regional, and landscape scales. The range-wide extents of these models allow ecoregion- scale assessments, which are more biologically appropriate than analyses at smaller extents defined by political boundaries, such as within states or counties (Scott and others, 1993).

\section{Other Literature Related to GAP Species Habitat Distribution Models}

Boykin, K.G., Drost, C., and Wynne, J.J., 2007, A gap analysis of terrestrial vertebrate species on the Colorado PlateauAssessment from the Southwest Regional Gap Analysis Project, in van Riper, C., III, and Sogge, M.K., eds., The Colorado Plateau III-Integrating research and resources management for effective conservation: Tucson, University of Arizona Press, p. 77-107.

Csuti, B., Polasky, S., Williams, P.H., Pressey, R.L., Camm, J.D., Kershaw, M., Kiester, A.R., Downs, B., Hamilton, R., Huso, M., and Sahr, K., 1997, A comparison of reserve selection algorithms using data on terrestrial vertebrates in Oregon: Biological Conservation, v. 80, issue 1, p 83-97.

Homer, C., Dewitz, J., Fry, J., Coan, M., Hossain, N., Larson, C., Herold, N., McKerrow, A., VanDriel, J.N., and Wickham, J., 2007, Completion of the 2001 National Land Cover Database for the Conterminous United States: Photogrammetric Engineering and Remote Sensing, v. 73, no. 4, p. 337-341, accessed July 30, 2018, at https://www.researchgate.net/profile/Collin_Homer/ publication/237239863_Completion_of_the_2001 National_Land_Cover_Database_for_the_Conterminous

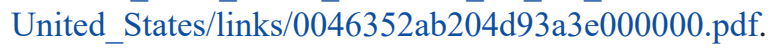

Iglecia, M.N., Collazo, J.A., and McKerrow, A.J., 2012, Use of occupancy models to evaluate expert knowledge-based species-habitat relationships: Avian Conservation and Ecology, v. 7, no. 2, article 5, accessed on July 15, 2018, at http://dx.doi.org/10.5751/ACE-00551-070205.

Kiester, A.R., Scott, J.M., Csuti, B., Noss, R., Butterfield, B., Sahr, K., and White, D., 1996, Conservation priorities using GAP data: Conservation Biology, v. 10, issue 5, p. 13321342.

Lorenz, T.J., Vierling, K.T., Vogeler, J., Lonneker, J., and Aycrigg, J., 2015, Incorporating shrub and snag specific LiDAR data into GAP wildlife models: Journal of Fish and Wildlife Management, v.6, issue 2, p. 437-447, accessed on July 30, 2018, at http://dx.doi.org/10.3996/092013JFWM-064 
Lowry, J., Ramsey, R.D., Thomas, K., Schrupp, D., Sajwaj, T., Kirby, J., Waller, E., Schrader, S., Falzarano, S., Langs, L., Manis, G., Wallace, C., Schulz, K., Comer, P., Pohs, K., Rieth, W., Velasquez, C., Wolk, B., Kepner, W., Boykin, K., O’Brien, L., Bradford, D., Thompson, B., and PriorMagee, J., 2007, Mapping moderate-scale land-cover over very large geographic areas within a collaborative framework-A case study of the Southwest Regional Gap Analysis Project (SWReGAP): Remote Sensing and the Environment, v. 108, issue 1, p. 59-73, accessed on July 30, 2018, at https://www.sciencedirect.com/science/article/pii/ S0034425706004524.

McKerrow, A.J., Davidson, A., Earnhardt, T.S., and Benson, A.L., 2014, Integrating recent land cover mapping efforts to update the National Gap Analysis Program’s species habitat map: The International Archives of the Photogrammetry, Remote Sensing and Spatial Information Sciences, v. XL-1, p. 245-252, accessed on July 30, 2018, at https:// www.int-arch-photogramm-remote-sens-spatial-inf-sci.net/ XL-1/245/2014/.

Mehaffey, M.R., Tankersley R., Jr, Miller, L., and Smith, E., 2009, Evaluating habitat vulnerability to hazardous air pollutants in the southeastern United States: Integrated Environmental Assessment and Management, v. 5, issue 1, p.150-157, accessed July 30, 2018, at https://doi. org/10.1897/IEAM_2008-040.1.

North American Bird Conservation Initiative, U.S. Committee, 2011, The state of the birds 2011 report on public lands and waters: U.S. Department of Interior: Washington, D.C., $48 \mathrm{p}$.

North American Bird Conservation Initiative, U.S. Committee, 2014, The state of the birds 2014 report: U.S. Department of the Interior, Washington, D.C., 16 p.

\section{Data Access}

Each of the species ranges and models are available to the public through the USGS ScienceBase Repository. There are two collections, one for the species ranges available at https:// doi.org/10.5066/F7Q81B3R (USGS, 2018b) and one for the species habitat distribution models available at https://doi. org/10.5066/F7V122T2 (USGS, 2018a).

Individual ScienceBase items for each species are available within each collection. The items represent a useful collection of information and data related to the ranges and models. For example, the literature references used in in the species habitat models are included in the "Species Habitat Model Report” and "Machine Readable Habitat Database Parameters" files attached to each habitat map item.

In addition, the produced data and detailed metadata with linkages to ancillary datasets used in the model are included in the ScienceBase items. Individual datasets used in the modeling process with these habitat model parameters are also made available in the ScienceBase Repository (https://www.sciencebase.gov/catalog/item/5644f3c1e4b0aafbcd0188f1 (USGS, 2018a). (For a general description of the ancillary datasets see table 4.1.) The "Machine Readable Habitat Database Parameters" Java script object notation (JSON) file attached to each species habitat map item has an "input_layers" object that contains the specific parameter names and references (via Digital Object Identifier) to the input data used with that parameter.

The individual species models used to generate the richness for this report are available at https://gapanalysis.usgs. gov/apps/species-data-download/ and through the science base repository (https://doi.org/10.5066/F7V122T2).

A description of the USGS Science Analytics and Synthesis (SAS) Program which houses the GAP Project is available at https://www.usgs.gov/core-science-systems/ science-analytics-and-synthesis.

\section{Naming Conventions and Codes}

A composite version code is employed to allow the user to track the spatial extent, the date of the ground conditions, and the iteration of the data set for that extent/date. For example, CONUS_2001v1 represents the spatial extent of the CONUS, the ground condition year of 2001, and the first iteration (v1) for that extent/date. The GAP species code is used in conjunction with the version code to identify specific data sets or files (that is, Cooper's Hawk Habitat Map is named bCOHAx_CONUS_2001v1_HabMap).

\section{Creating the Richness Maps}

For each of the four vertebrate classes, we created richness maps based on summing binary (habitat/non-habitat) versions of the individual species habitat distribution models. Only species level models were included in calculating richness maps. Note the species level models represent the modeled habitat for all of the related subspecies and therefore for this species level analysis we used only the 1,590 species-level habitat distribution maps. As mentioned above, GAP habitat maps are coded with values 1-3 depending on the season (for example, summer, winter or year-round), so we needed to first reclass each habitat map to a binary map of 1 s and 0 s, where 1 indicated that a cell was suitable habitat during any season, and 0 indicated that a cell was unsuitable during all seasons. Year round indicates suitable habitat in both summer and the winter seasons. 


\section{Results}

Species richness across the conterminous U.S. based on summing habitat distribution models for each of the four classes (amphibians, birds, mammals, and reptiles) are presented in figures $2-5$. The highest richness for amphibians was 42 species. Amphibian-rich areas occurred throughout riparian and wetland habitats of the Southeast, Coastal Pacific, and the Upper Midwest regions (fig. 2). Large areas of the west and Midwest had relatively low amphibian richness. Maximum bird richness was 163 with concentrations of high richness in the Intermountain West, Pacific and Gulf Coast regions, and scattered patches throughout the East and Midwest (fig. 3). Maximum mammal richness reached 72 species with highest richness concentrated in the Desert Southwest and southern portions of the Intermountain Region. Areas of high mammal richness were mapped throughout the west, with a few isolated areas of low richness corresponding to Intermountain Basins (fig. 4). In general, mammal richness was higher in the West than either the eastern or Midwestern U.S. Maximum richness of 54 species of reptiles was highly concentrated in the Desert Southwest and scattered throughout the southeast (fig. 5).

\section{Discussion}

The maps developed for this project are the first to show patterns of species richness based on suitable habitat for the terrestrial vertebrates of CONUS. The patterns of species richness represent the combination of the biogeographic evolution of the taxa (that is, species ranges) and suitable landscape context (that is, habitat as represented by Ecological Systems and other mapped environmental variables). The approach presented in this paper can increase the value and utility of the resultant maps. For example, as McKerrow and others (2018) showed that excluding unsuitable areas by using individual species models changed spatial patterns of species richness and richness hotspots as compared to spatial patterns derived using species range data or coarser resolution habitat distribution data.

The species habitat distributions and the derived species richness maps provide a nationally consistent metric for the status of terrestrial vertebrate biodiversity. The species distribution models, used in conjunction with the Protected Areas Database for the U.S. (https://gapanalysis.usgs.gov/ padus/), more accurately characterize the current protection status for each species habitat in the National Biogeographic Map (https://maps.usgs.gov/biogeography/) and facilitate scale-specific analyses. For example, if an ecoregional planning team is interested in understanding the patterns of species richness within their region, they can carry out an analysis that only includes the species specific to the region with the richness areas evaluated based on that ecoregion's maximum richness.
While we have focused here on species richness patterns for CONUS, these data support analyses beyond evaluating protection and potential threats to species habitats. Individual species of interest, groups of species with common requirements, or specific habitat types can also be evaluated at various extents. If additional spatial data sets representing risks to these species are available, such as changes in hydrologic regime, deforestation or invasive-driven changes to plant communities, the elements of terrestrial vertebrate biodiversity most at risk can be discerned in any given system.

The suitable habitat distribution models described here and used to produce the Terrestrial Vertebrate Species Richness Maps for the CONUS can be useful in addressing additional questions directly relevant to land managers and conservation planners. The approach and resultant model outputs can be especially relevant to the Department of Interior agencies in managing wildlife populations and their habitats across the nation. Species habitat maps have already been used to identify the species likely to be affected by various land use scenarios (Martinuzzi and others, 2015) and to model the potential impact on individual species (Tarr and others, 2016). In addition, similar data have served as a basis for quantifying ecosystem services related to biological diversity (Boykin and others, 2013) and to inform wind and solar energy facility siting (Thomas and others, 2018).

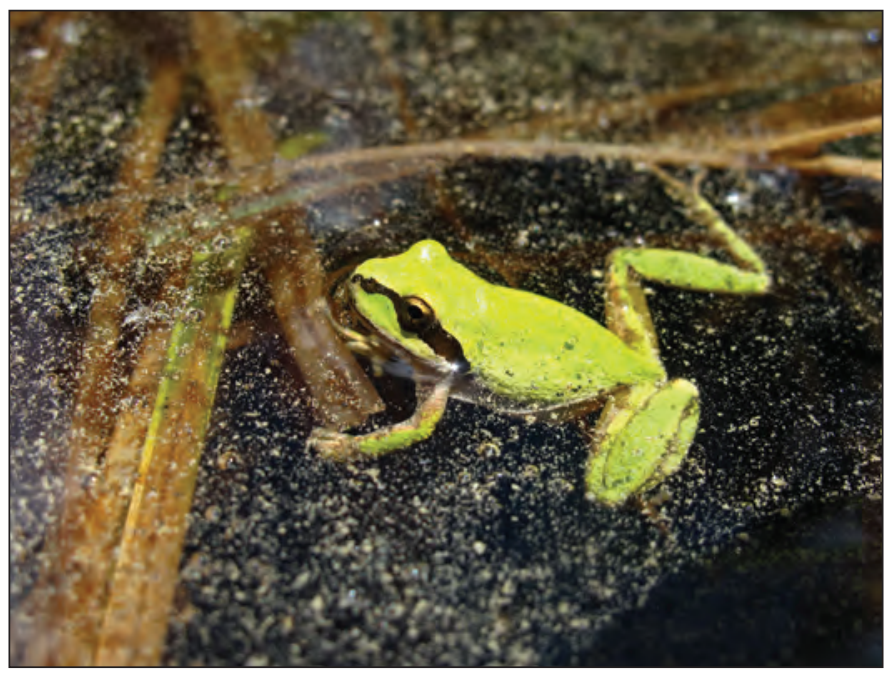

Photograph of a Pseudacris regilla (Pacific Chorus Frog) in a meadow located in Yosemite National Park, California, by Devin Edmonds, U.S. Geological Survey, July 1, 2012. Accessed Oct. 4, 2018, at https://www.usgs.gov/media/ images/pacific-chorus-frog-1. 


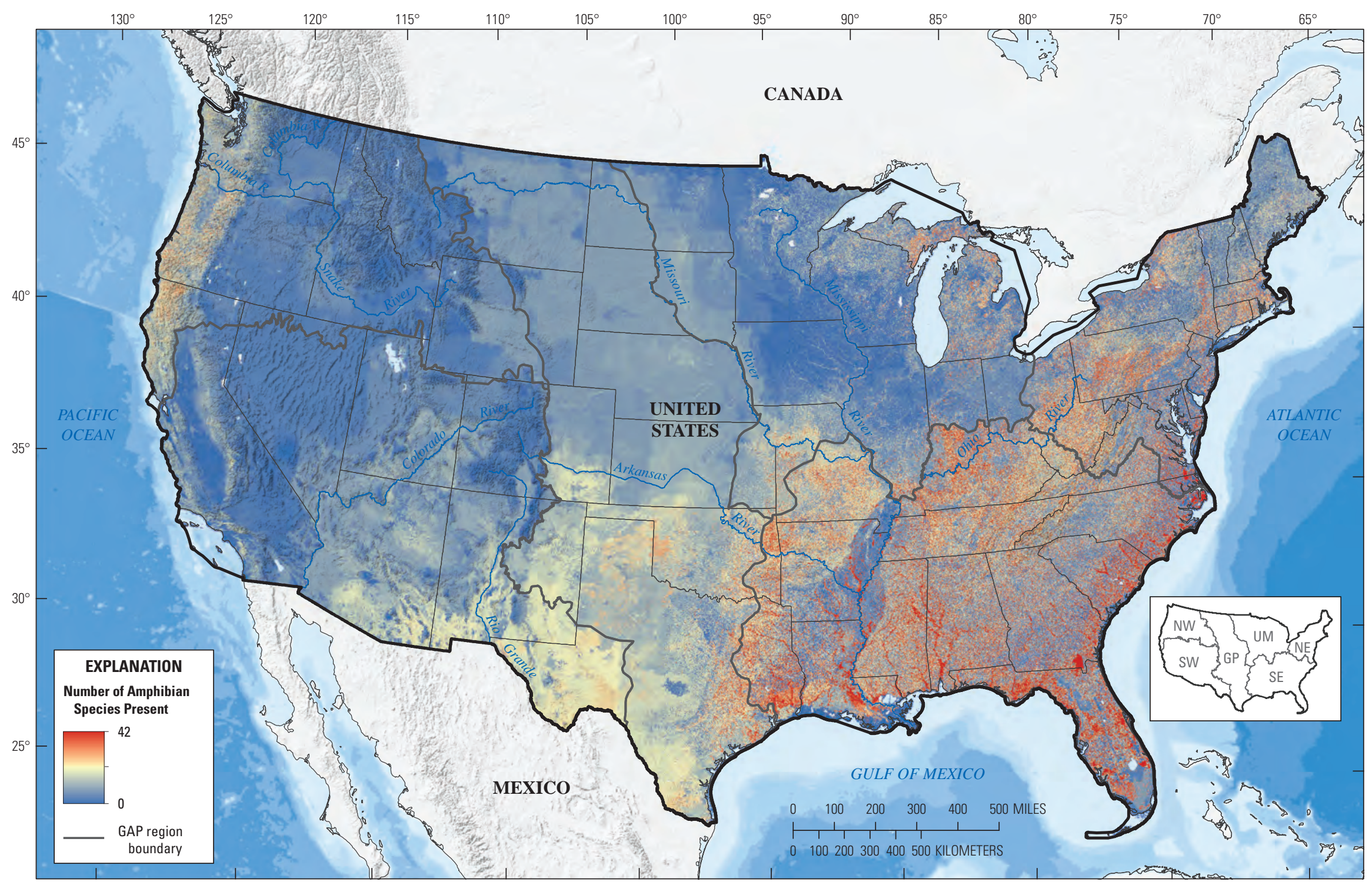

Base from U.S. Geological Survey digital data, The National Map,

accessed December 2018, at https://viewer.nationalmap.gov/basic

Figure 2. Map of amphibian species richness derived from species habitat distribution models for the conterminous U.S. The habitat distribution map for each of the

282 amphibian species were added together to determine amphibian richness for each $30 \mathrm{~m}$ cell. The maximum richness indicates there are areas where potential habitat for up to 42 amphibian species exists. Gap Analysis Project (GAP) region boundaries: NW, northwest; SW, southwest; GP, Great Plains; UM, upper Midwest; SE, southeast;

$\mathrm{NE}$, northeast. 


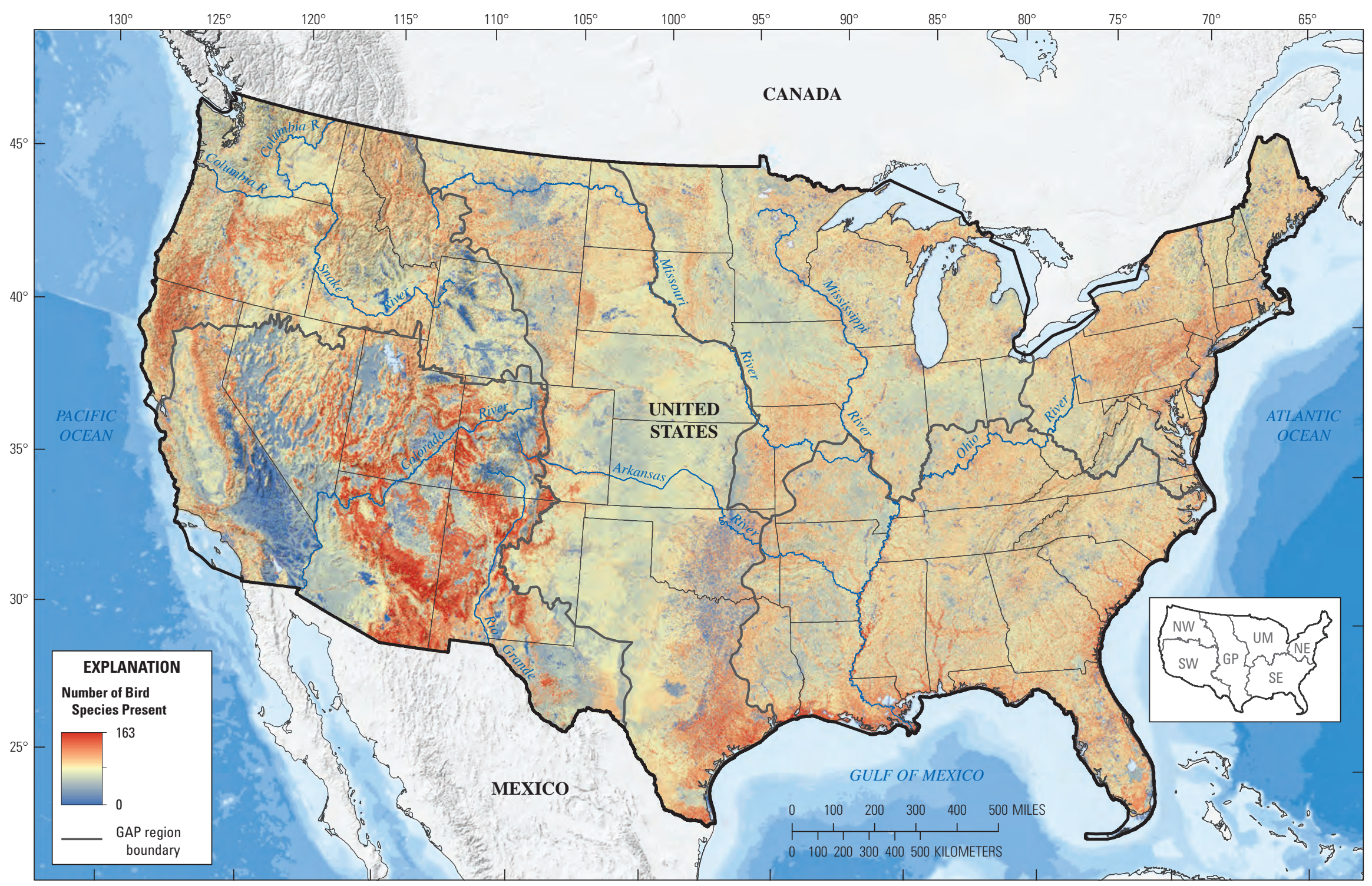

Figure 3. Map of bird species richness derived from species habitat distribution models for the conterminous U.S. The habitat distribution map for each of the 621 bird species were added together to determine bird richness for each $30 \mathrm{~m}$ cell. The maximum richness indicates there are areas where potential habitat for up to 163 bird species exists. Gap Analysis Project (GAP) region boundaries: NW, northwest; SW, southwest; GP, Great Plains; UM, upper Midwest; SE, southeast; NE, northeast. 


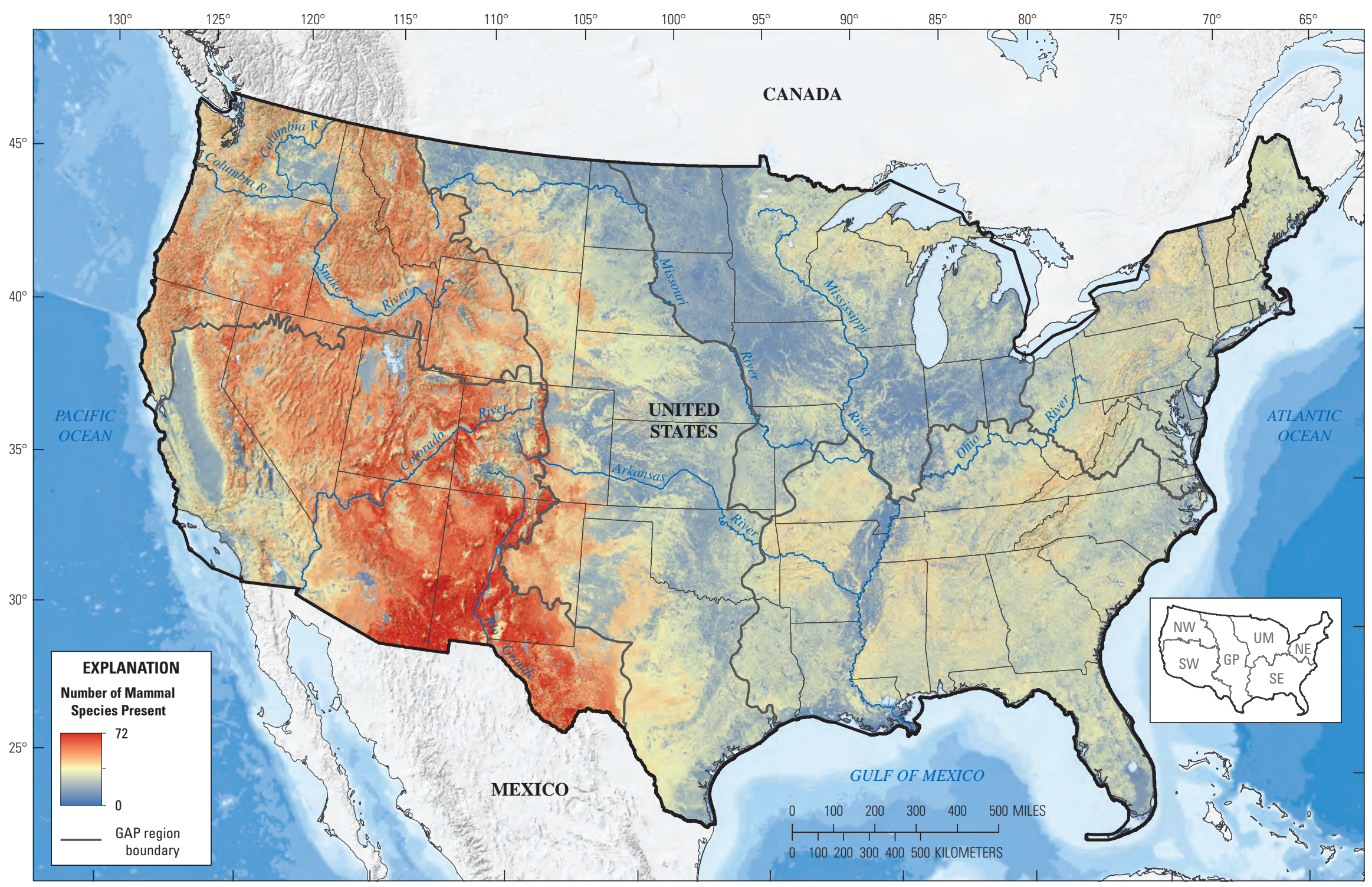

Base from U.S. Geological Survey digital data, The National Map,

accessed December 2018, at https://viewer.nationalmap.gov/basic

Albers Equal-Area Conic projection, North American Datum of 1983

Figure 4. Map of mammal species richness derived from species habitat distribution models for the conterminous U.S. The habitat distribution map for each of the 365 mammal species were added together to determine mammal richness for each $30 \mathrm{~m}$ cell. The maximum richness indicates there are areas where potential habitat for up to 72 mammal species exists. Gap Analysis Project (GAP) region boundaries: NW, northwest; SW, southwest; GP, Great Plains; UM, upper Midwest; SE, southeast; NE, northeast. 


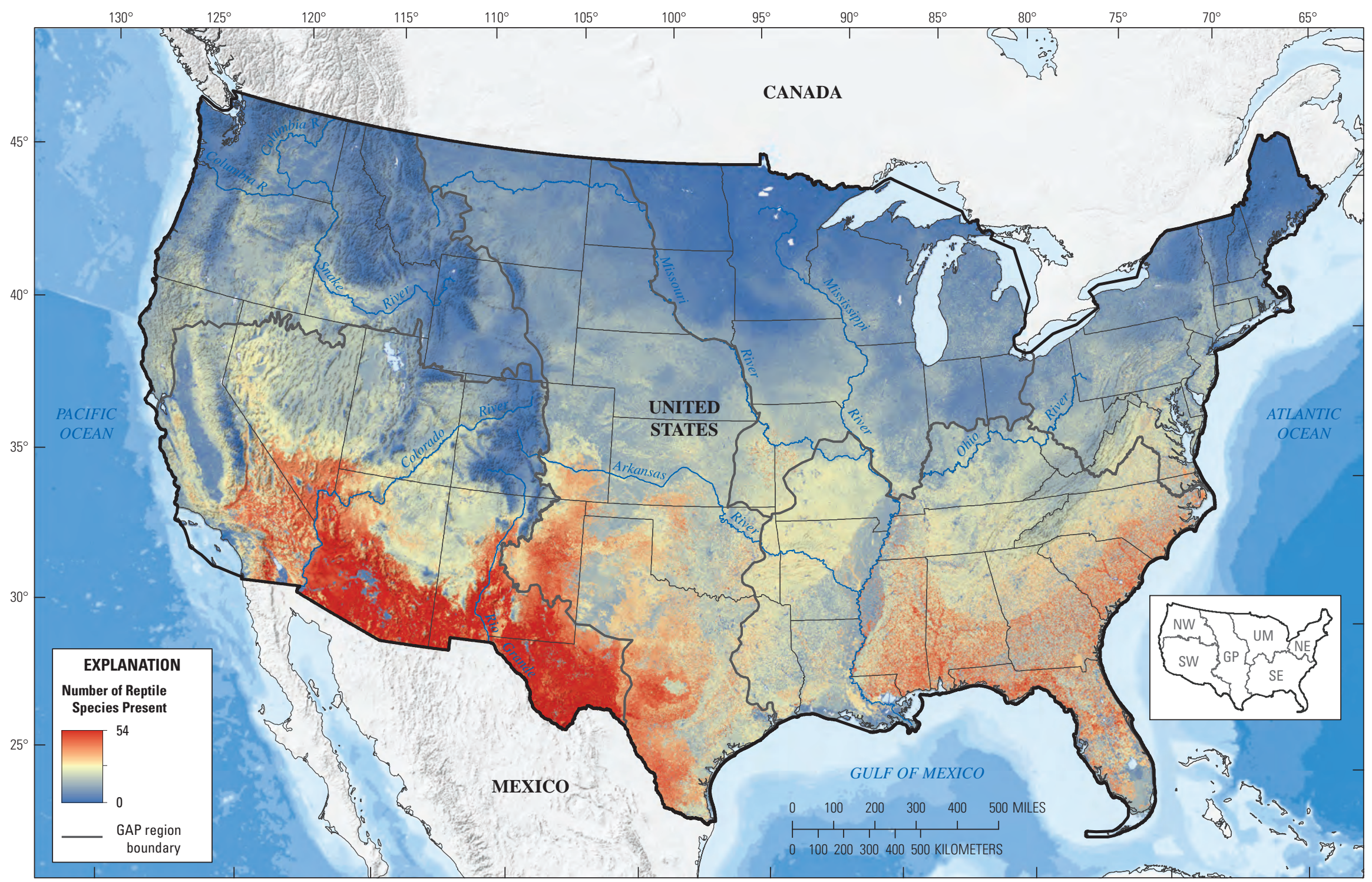

Figure 5. Map of reptile species richness derived from species habitat distribution models for the conterminous U.S. The habitat distribution map for each of the 322 reptile species were added together to determine amphibian richness for each $30 \mathrm{~m}$ cell. The maximum richness indicates there are areas where potential habitat for up to 54 reptile species exists. Gap Analysis Project (GAP) region boundaries: NW, northwest; SW, southwest; GP, Great Plains; UM, upper Midwest; SE, southeast; NE, northeast. 


\section{Programmatic Considerations}

\section{Modeling Approach}

If point occurrence data become more accessible for a larger number of species and statistical methods can be expanded for using those data to model species distributions, inductive models can be increasingly used to map species distributions. The authors see the value in the use of inductive models for statistical prediction based on occurrence when data are sufficient because of the increased strength of the quantitative comparisons and validation. That said, sufficient data are not available for all species for a nation-wide biodiversity evaluation. Given the goal of creating nationally consistent models for all terrestrial vertebrates, it is inevitable that some species will be data rich and others, data poor. We put the species habitat distribution models in this report forward as a reasonable and consistent modeling approach at a moderate resolution $(30 \mathrm{~m})$ across both a wide geographic extent and for a wide range of species. GAP has directly tested inductive approaches in two regional projects (Aycrigg and others, 2015) with the program's objectives specifically in mind. In both cases, deductive models were typically found to be the best final model after expert review and an evaluation of the extent of modeled habitat relative to the range of the species. While more limited in quantitative evaluation, validity of deductive models is reliant on expert review and intuitive modeling parameters.

Core datasets selected for the models represent the best known, moderate resolution data with documented influence on species habitat selection. Certainly, there are some species requirements that cannot be mapped using remotely sensed data, so our models represent a coarse filter for species habitat. If a species uses pine snags, and we have pine communities well mapped, they may make a good proxy for the true habitat feature. If we only had maps of conical crowned forests, that would be a lesser habitat proxy and may be inappropriate. Accordingly, we chose to use a deductive modelling approach because it is currently the most feasible method for achieving the goal of assessing the status of terrestrial vertebrate species diversity. Future efforts should evaluate how well the variables represent true habitat features and the range in variability for the models overall.

While we are constrained by which datasets can be used at a national extent, there are opportunities to review additional data with respect to improving species habitat distribution models at smaller extents or for a short list of species. For example, Martinuzzi and others (2009) have shown the potential for improving species habitat models with the use of LiDAR data. Similarly, Glisson and others (2017) were able to refine predictions of species occupancy for the Yuma Rail based on the specific landscape-context variables.

\section{Model Review and Assessment}

Over the course of the GAP, expert reviews of models have been carried out via regional workshops in the Southwest (Boykin and others, 2007), Northwest (Aycrigg and others, 2015) and Alaska (Gotthardt and others, 2014). Reviews and comments were also solicited from biologists involved with incorporating GAP models into the Western Governors' Association Crucial Habitat Assessment Tool. In that effort the Species of Concern workgroup developed a process for agency review on a common suite species distribution maps. External review played an important role in the refinement and vetting of the GAP models, but notable challenges were encountered. For example, eliciting species model reviews was time consuming and the review process didn't always result in a consensus on a species habitat model or in an actionable item, and inherent biases resulted from uneven geographic representation of, or participation by, the attendees. Further, few experts have knowledge across the entire range of a species and where overlap in their knowledge does exist across a broad extent, experts often disagree (Drescher and others, 2013).

While individual species models have been assessed at the state and regional extents (Aycrigg and others, 2015; McKerrow and others, 2006; Peterson and others, 2001), we have not carried out a CONUS-wide accuracy assessment of any species model. GAP efforts in the Pacific Northwest and Alaska compared inductive and deductive model approaches using occurrence records to assess "model accuracy" or the percent of occurrence records that fell in modeled habitat (Aycrigg and others, 2015). That same study chose to reject models where less than 75 percent of the mapped range included modeled habitat or where the expert review suggested a model should be rejected. Importantly, Aycrigg and others (2015) showed that careful screening of data precision in spatial representation can provide a reasonable assessment of the omission error relative to the modeled habitat. In some cases, those errors can be used to identify geographies not well represented in the occurrence record datasets, indicating a need for additional surveys. Similarly, omission in the deductive models could indicate habitat affinities that were missed during model development.

Assessing commission errors in which a species is modeled to occur but does not, is far more challenging than it is for omission errors. Without standard repeated surveys across the range of a species, it is impossible to say that a species will not use a specific habitat. Because our species habitat distribution models remove unsuitable areas within the range of the species we assume they have fewer commission errors than the next closest complete dataset for the nation (McKerrow and others, 2018). The challenge is to refine the species distribution models by reducing commission, without adding or increasing omission error.

Given that habitat distributions represent areas that are described by model parameters to be habitat for a species, another approach for assessment is to test for the presence of the landscape factors used in the models. 
Boykin and others (2010) did this type of assessment for the southwest regional project. Not surprisingly, they found that variables that are directly measured (for example, slope, soil composition, and rock outcrop) had higher concordance with modeled habitat than descriptive variables (for example, ecological system, and landform).

Finally, as with non-statistical modeling approaches where it is impossible to measure uncertainty, sensitivity analyses are used to identify the effect of uncertainty or error on the final result. Given the range of data quality and quantity across the species included here, we suggest four topics for improving our understanding of model quality.

1. Detailed expert review where possible to refine the species habitat associations, model parameters, and (or) identify recent changes in the range of the species.

2. Assess omission where presence-only data are available across the range of a species.

3. Rank levels of certainty (for example, range, abundance of literature, appropriateness of available modeling parameters, and final model) as a method for determining when revisions can be made.

4. Conduct sensitivity analysis specific to a question being addressed with the species habitat or richness maps.

\section{Comparing Models}

We acknowledge that the data used in our analysis may not represent the best source of predictive distribution data for individual species in a given geographical extent where extensive field work can support a more intensive modeling approach; but we do put our analysis of these data forward as a reasonable and consistent modeling approach at a moderate resolution (30 m) across both a wide geographic extent and for a wide range of species.

In evaluating and applying the species ranges and habitat distribution models it is important to understand the temporal resolution of the data being presented. The Gap Analysis Project evolved programmatically from individual state to regional projects and then to the national effort. While much was learned during the development of regional datasets, the work on the national extent models started in earnest in 2008, therefore the species list, literature review, and creation of the national ancillary datasets reflect work since then. In other words, the models reflect the understanding gleaned from the literature between 2008 and 2017. We report the date of the model completion (End Date) in the metadata for each species to give the end-user an understanding of the timeframe for the information used in the model. The heavy reliance of the habitat distribution models on the 2001 land cover means that the maps reflect the understanding of the species habitat requirements from the literature at the time the habitat association literature review was completed and the ground conditions of the 2001 landscape.

\section{Future Directions}

With the models completed, our primary focus is now on the use of the models for national and regional conservation assessments. We have considered a full list of species, and consistency among individual species data allows for the ability to make meaningful subsets of the full species list to address specific questions related to better understanding biogeography of terrestrial vertebrates, as well as to identify species vulnerable to specific threats. In addition, we would like to leverage the growing access to occurrence records to enhance the information related to species ranges. For future revisions, we would like to include enhanced documentation of linkages between model parameter selection and literature sources used to make model parameter decisions. Ancillary datasets used in the modeling process would be examined and updated as needed, and software methods could be adopted that will run the process fully with code that can be made publicly available. Finally, we plan to incorporate research related to assessing error in the models and the sensitivity of the analytical outcomes.

\section{References Cited}

Aycrigg, J., Beauvais, G., Gotthardt, T. Huettmann, F., Pyare, S., Andersen, M., Keinath, D., Lonneker, J., Spathelf, M., and Walton, K. 2015, Novel approaches to modeling and mapping terrestrial vertebrate occurrence in the Northwest and Alaska-An Evaluation: Northwest Science, v. 89, issue 4, p. 355-381, accessed on July 30, 2018, at http:// www.bioone.org/doi/abs/10.3955/046.089.0405.

Boykin, K.G., Kepner, W.G., Bradford, D.F., Guy, R.K., Kopp, D.A., Leimer, A.K., Samson, E.A., East, N.F., Neale, A.C., and Gergely, K.J., 2013, A national approach for mapping and quantifying habitat-based biodiversity metrics across multiple spatial scales: Ecological Indicators, Biodiversity Monitoring, v. 33, p. 139-147, accessed on July 30, 2018, at https://doi.org/10.1016/j.ecolind.2012.11.005.

Boykin, K.G., Thompson, B.C., Deitner, R.A., Schrupp, D., Bradford, D., O’Brien, L., Drost, C., Propeck-Gray, S., Rieth, W., Thomas, K.A., Kepner, W., Lowry, J., Cross, C., Jones, B., Hamer, T., Mettenbrink, C., Oakes, K.J., Prior-Magee, J., Schulz, K., Wynne, J.J., King, C., Puttere, J., Schrader, S., and Schwenke, Z., 2007, Predicted animal habitat distributions and species richness, chap. 3 of PriorMagee, J.S., Boykin, K.G., Bradford, D.F., Kepner, W.G., Lowry, J.H., Schrupp, D.L., Thomas, K.A., Thompson, B.C., eds., Ecoregional gap analysis of the southwestern United States, the Southwest Regional Gap Analysis Project final report: U.S. Geological Survey, Gap Analysis Program. [Also available at http://swregap.nmsu.edu/report/ swregap\%20final\%20report.pdf.] 
Boykin, K.G., Thompson, B.C., and Propeck-Gray, S., 2010, Accuracy of gap analysis habitat models in predicting physical features for wildlife-habitat associations in the southwest U.S.: Ecological Modelling, v. 221, issue 23, p. 2769-2775. [Also available at https://doi.org/10.1016/j. ecolmodel.2010.08.034.]

Buchanan G.M., Donald P.F., and Butchart S.H.M., 2011, Identifying priority areas for conservation-A global assessment for forest-dependent birds: PLoS ONE, v. 6, issue 12, e29080. [Also available at https://doi.org/10.1371/journal. pone.0029080.]

Comer, P.J., Faber-Langendoen D., Evans, R., Gawler, S.C., Josse, C., Kittel, G., Menard, S., Pyne, M., Reid, M., Schulz, K., Snow, K., and Teague, J., 2003, Ecological systems of the United States-A working classification of U.S. terrestrial systems: Arlington, NatureServe. [Also available at http://www.natureserve.org/biodiversity-science/ publications/ecological-systems-united-states.]

Csuti, B., and Kiester A.R., 1996, Hierarchical gap analysis for identifying priority areas for biodiversity, in Scott, J.M., Tear, T.H., and Davis, F.W., eds., Gap Analysis-A landscape approach to biodiversity planning: Bethesda, American Society for Photogrammetry and Remote Sensing, $320 \mathrm{p}$.

Di Marco, M., Watson, J.E.M., Possingham, H.P., and Venter, O., 2017, Limitations and trade-offs in the use of species distribution maps for protected area planning: Journal of Applied Ecology, v. 54, issue 2, p. 402-411, accessed July 30, 2018, at https://doi.org/10.1111/1365-2664.12771.

Drescher, M., Perera, A.H., Johnson, C.J., Buse, L.J., Drew, C.A., and Burgman, M.A., 2013 Toward rigorous use of expert knowledge in ecological research: Ecosphere v. 4, issue 7, p. 1-26, accessed July 30, 2018, at https://doi. org/10.1890/ES12-00415.1.

Ferrier, S., Powell, G.V.N, Richardson, K.S., Manion, G., Overton, J.M., Allnutt, F., Cameron, S.E., Mantle, K., Burgess, N.D., Faith, D.P., Lamoreux, J.F., Kier, G., Hijmans, R.J., Funk, V.S., Cassis, G.A., Fisher, B.L, Flemons, P., Lees, D., Lovett, J.C., and Van Rompaey, S.A.R., 2004, Mapping more of terrestrial biodiversity for global conservation assessment: Bioscience, v. 54, issue 12, p. 1101-1109. [Also available at https://academic.oup.com/ bioscience/article/54/12/1101/329621.]

Ficetola G.F., Rondinini C., Bonardi A., Baisero D., and Padoa-Schioppa E., 2015, Habitat availability for amphibians and extinction threat-A global analysis: Diversity and Distributions, v. 21, issue 3, p. 302-311, accessed July 30, 2018, at https://doi.org/10.1111/ddi.12296.]
Flather, C.H., Wilson, K.R, and Shriner, S.A., 2009, Geographic approaches to biodiversity conservation-Implications of scale and error to landscape planning, chap. 4 of Millspaugh, J.J., and Thompson, F.R., III, eds., Models for planning wildlife conservation in large landscapes: Burlington, Academic Pres, p. 85-121, accessed February 29, 2016, at https://www.fs.fed.us/rm/pubs_other/ rmrs_2009_flather_c001.pdf.

Glisson, W.J., Conway, C.J., Nadeau, C.P., and Borgmann, K.L., 2017, Habitat models to predict wetland bird occupancy influenced by scale, anthropogenic disturbance, and imperfect detection: Ecosphere, v. 8, issue 6, accessed on July 30, 2018, at https://doi.org/10.1002/ecs2.1837.

Gotthardt, T., Pyare, S., Huettmann, F., Walton, K., Spathelf, M., Nesvacil, K., Baltensperger, A., Humphries, G., and Fields, T., 2014, Predicting the range and distribution of terrestrial vertebrate species in Alaska: Anchorage, University of Alaska, 42 p., plus appendices, accessed July 30, 2018, at http://akgap.uaa.alaska.edu/publications.

Groves, C.R., Game, E.T., Anderson, M.G., Cross, M., Enquist, C., Ferdaña, Z., Girvetz, E., Gondor, A., Hall, K.R., Higgins, J., Marshall, R., Popper, K., Schill, S., and Shafer, S., 2012, Incorporating climate change into systematic conservation planning: Biodiversity Conservation v. 21, issue 7, p. 1651-1671, accessed July 30, 2018, at https:// link.springer.com/article/10.1007/s10531-012-0269-3.

Homer, C.J., Dewitz, J., Fry, M., Coan, N., Hossain, C., Larson, N., Herold, A., McKerrow, J.N., VanDriel, J.N., and Wickham, J., 2007, Completion of the 2001 National Land Cover Database for the Conterminous United States: Photogrammetric Engineering and Remote Sensing, v. 73, issue 4, p. 337-341, accessed July 30, 2018, at https:/www.researchgate.net/profile/Collin_Homer/ publication/237239863_Completion_of_the_2001 National_Land_Cover_Database_for_the_Conterminous _ United_States/links/0046352ab204d93a3e000000.pdf.

Hurlbert, A.H., and Jetz, W., 2007, Species richness, hotspots, and the scale dependence of range maps in ecology and conservation: National Academy of Sciences, v. 104, no. 33, [Proceedings] p. 13384-13389, accessed July 30, 2018, at https://doi.org/10.1073/pnas.0704469104.

Hurlbert, A.H., and White, E.P., 2005, Disparity between range map- and survey-based analyses of species richness-Patterns, processes and implications: Ecology Letters, v. 8, p. 319-327, accessed July 30, 2018, at https://doi. org/10.1111/j.1461-0248.2005.00726.x.

Jenkins, C.J., Van Houtan, K.V., Pimm, S., and Sexton, J.O., 2015, U.S. protected lands mismatch biodiversity priorities: National Academy of Sciences, v. 112, no. 16, [Proceedings] p. 5081-5086, accessed July 30, 2018, at https://doi. org/10.1073/pnas.1418034112. 
Johnson, R.R., Baxter, C.K., and Estey, M.E., 2009, An emerging agency-based approach to conserving populations through strategic habitat conservation, chap. 7 of Millspaugh, J.J., and Thompson, F.R., III, eds., Models for planning wildlife conservation in large landscapes: Academic Press, 688 p.

Martinuzzi, S., Withey, J.C., Pidgeon, A.M., Plantinga, A.J., McKerrow, A.J., Williams, S.G., Helmers, D.P., and Radeloff, V.C., 2015, Future land-use scenarios and the loss of wildlife habitats in the southeastern United States: Ecological Applications, v. 25, issue 1, p. 160-171, accessed July 30, 2018, at https://esajournals.onlinelibrary.wiley.com/ doi/10.1890/13-2078.1.

Martinuzzi, S., Vierling, L.A., Gould, W.A., Falkowski, M.J., Evans, J.S., Hudak, A.T., and Vierling, K.T., 2009, Mapping snags and understory shrubs for a LiDAR-based assessment of wildlife habitat suitability: Remote Sensing of Environment, v. 113, issue 12, p. 2533-2546, accessed July 30, 2018, at https://doi.org/10.1016/j.rse.2009.07.002.

McKerrow, A.J., Tarr, N.M., Rubino, M.J., and Williams, S.G., 2018, Patterns of species richness hotspots and estimates of their protection are sensitive to spatial resolution: Diversity and Distributions, v. 24, issue 10, p. 1464-1477, accessed July 30, 2018, at https://doi.org/10.1111/ddi.12779.

McKerrow, A.J., Williams, S.G., and Collazo, J.A., 2006, A GAP analysis of North Carolina, The North Carolina Gap Analysis Project, Final Report: U.S. Geological Survey, The National Gap Analysis Program, 110 p., and appendixes. [Also available at http://www.basic.ncsu.edu/ncgap/ NCFinal\%20Report.pdf.]

Morrison, M.L., and Hall, L.S., 2002, Standard terminologyToward a common language to advance ecological understanding and application, chap. 2 of Scott, J.M., Heglund, P.J., Morrison, M.L., Haufler, J.B., Raphael, M.G., Wall, W.W., and Samson, F.B., eds., Part I-Conceptual framework, Predicting species occurrences-Issues of accuracy and scale: Washington, D.C., Island Press, p. 43-52.

Morrison, M.L., Marcot, B.G., and Mannan, R.W., 2006, Wildlife-habitat relationships (3d ed.): Washington, D.C., Island Press, p. 258.

Noss, R.F. and Cooperrider, A.Y., 1994, Saving nature's legacy_Protecting and restoring biodiversity: Washington, D.C., Island Press, 341 p.

Peterson, C.R., Burton, S.R., Pilliod, D.S., Lee, J.R., Cossel, J.O, Jr., and Llewellyn, R.L., 2001, Assessing the accuracy of GAP analysis predicted distributions of Idaho amphibians and reptiles: Covelo, Island Press, GAP Analysis Bulletin, no. 10. p 25-28.
Probst, J.R., and Gustafson, E.J., 2009, A multiscale, stepwise approximation approach for wildlife conservation assessment and planning, chap. 7 of Millspaugh, J.J., and Thompson, F.R., III, eds., Models for planning wildlife conservation in large landscapes: Academic Press, p. 177-200.

Pulliam, H.R., 2000, On the relationship between niche and distribution: Ecology Letters, v. 3, issue 4, p. 349-361. [Also available at https://doi.org/10.1046/j.14610248.2000.00143.x.]

Rahbek, C., 2005, The role of spatial scale and the perception of large-scale species-richness patterns: Ecology Letters, v. 8, issue 2, p. 224-239. [Also available at https://doi. org/10.1111/j.1461-0248.2004.00701.x.]

Rondinini, C., Di Marco, M., Chiozza, F., Santulli, G., Baisero, D., Visconti, P. Hoffmann, M., Schipper, J., Stuart, S.N., Tognelli, M.F., Amori, G., Falcucci, A., Maiorano, L., and Boitani, L., 2011, Global habitat suitability models of terrestrial mammals: Philosophical Transaction of the Royal Society B, Biological Sciences, v. 366, p. 2633-2641, accessed July 30, 2018, at https://doi.org/10.1098/ rstb.2011.0113.

Ryan, J.C., 1992, Life Support-Conserving Biological Diversity: Worldwatch Paper 108, Worldwatch Institute, 62 p.

Scott, J.M., Davis, F., Csuti, F., Noss, R., Butterfield, B., Groves, C., Anderson, H., Caicoo, S., D’Erchia, F., Edwards, T.C., Ulliman, J., and Wright, G., 1993, Gap analysis-A geographic approach to protection of biological diversity: Wildlife Monographs, no. 123, p. 3-41. [Also available at https://www.jstor.org/stable/3830788.]

Tarr, N.M., Rubino, M.J., Costanza, J.K., McKerrow, A.J., Collazo, J.A., and Abt, R.C., 2016, Projected gains and losses of wildlife habitat from bioenergy-induced landscape change: Bioenergy, Global Change Biology, v. 9, issue 5, p. 909-923, accessed July 30, 2018, at https://doi. org/10.1111/gcbb.12383.

Thomas, K.A., Jarchow, C.J., Arundel, T.R., Jamwal, P., Borens, A., and Drost, C.A., 2018, Landscape-scale wildlife species richness metrics to inform wind and solar energy facility siting-An Arizona case study: Energy Policy, v. 116, p. 145-152, accessed July 30, 2018, at https://www. sciencedirect.com/science/article/pii/S0301421518300600.

U.S. Geological Survey and U.S. Department of Agriculture Natural Resources Conservation Service, 2009, Federal standards and procedures for the National Watershed Boundary Dataset (WBD) (1st ed.): U.S. Geological Survey Techniques and Methods 11-A3, 55 p, accessed July 30, 2018 at https://pubs.usgs.gov/tm/11/a3/pdf/tm11-a3_1ed. pdf. 
U.S. Geological Survey, 2011, Core science analytics, synthesis, and library, Gap Analysis Project, 20110222, USGS Gap Analysis Project-Additional Data-Modeling regions: U.S. Geological Survey, accessed July 30, 2018 at https:// doi.org/10.5066/F77H1HGT.

U.S. Geological Survey, 2018a, Gap Analysis Project species habitat maps CONUS_2001; U.S. Geological Survey data release, accessed July 20, 2018 at https://doi.org/10.5066/ F7V122T2.

U.S. Geological Survey, 2018b, U.S. Geological Survey—Gap Analysis Project species range maps CONUS_2001: U.S. Geological Survey data release, accessed July 20, 2018 at https://doi.org/10.5066/F7Q81B3R.

Van Horne, B., 2002, Approaches to Habitat Modeling-The tensions between pattern and process and between specificity and generality, chap. 4 of Scott, M.J., Heglund, P.J., Morrison, M.L., Haufler, J.B., Raphael, M.G., Wall, W.A., and Samson, F.B., eds., Predicting species occurrencesIssues of accuracy and scale: Washington, D.C., Island Press, p. 63-72. 


\section{Appendix 1. Ancillary Datasets and Model Parameter Used in Species' Habitat Modeling}

\section{Land Cover and Derivatives}

\section{Land Cover}

The ecological systems mapped in the Gap Analysis Project (GAP) National Land Cover Data ver. 1.0 (2001) (U.S. Geological Survey [USGS], 2018b) were used as 'map units' to describe habitat types preferred by species. Map units are designated as either primary or secondary. Primary maps units are defined as those ecological systems critical for a species' reproduction and survival. Secondary map units are those ecological systems generally not critical for reproduction and survival, but typically are used in conjunction with primary map units for foraging, roosting, and (or) sub-optimal nesting locations. Secondary map units are selected only when located within a specified distance from primary map units.

\section{Patch Size}

The type and size of clusters of habitat was assessed with spatial modeling. We used patch size to indicate minimum amounts of contiguous habitat needed for a species. This variable required the calculation of cluster sizes in the modeling code during post processing. In other words, these model variables are not independent ancillary data layers.

Contiguous Patch-Minimum size (hectare [ha]) — This parameter is set using the most conservation values explicitly stated in the specie literature.

\section{Forest and Ecotone Habitats}

The ecotone (that is, edge) between forested and nonforested environments can be a critical aspect of habitat. We grouped map units into forested, non-forested, and shrubland/ woodland land cover types to create unique data layers. These data layers were then buffered at specified distances to identify species habitats. Aggregated map units can be compared and contrasted to identify areas of transition between these broad categories. They can also be used to identify core areas or contiguous blocks of similar type (that is, interior) through buffering.

Forested map units included deciduous forest, evergreen forest, mixed forest, palustrine forested wetland, and estuarine forested wetland.

Non-forested map units were defined as water, pasture/ hay, agricultural areas, urban/developed, marshes, beaches, and so forth.
Woodland/shrubland map units were defined as those ecological systems and land uses containing a majority of short, scrubby, woody vegetation or sparsely canopied treed vegetation.

\section{Ecotone Type and Width}

\section{Ecotone Type}

Forest/Open Ecotone Only-This data layer represents the transitional areas between forest and open, non-forested habitats.

Forest/Open Ecotone+Woodlands/Shrublands-The forest/open only ecotone does not consider environments with sparse canopies or scrubby vegetation, therefore this data layer includes woodland and shrubland map units that would otherwise be ignored. This dataset uses two data layers in tandem. The forest/open ecotone and the woodlands/shrublands (that is, wlsl) are calculated individually and then combined to depict a landscape that includes both ecotones.

\section{Ecotone Width}

This distance represents a symmetrically buffered edge (that is, $0 ; 30 ; 60 ; 120 ; 250 ; 500$; and 1,000 meters [m]). For example, an ecotone width of $500 \mathrm{~m}$ includes $250 \mathrm{~m}$ into forest and $250 \mathrm{~m}$ into open.

Buffer distances:

- Distances into ecotone (for example, forest edge): $0 ; 30 ; 60 ; 120 ; 250 ; 500 ; 1,000 ; 2,000 ; 4,000$, and $>4,000 \mathrm{~m}$

- Distances away ecotone (for example, forest edge: $>4,000 ; 4,000 ; 2,000 ; 1,000 ; 500 ; 250 ; 120 ; 60 ; 30$; and $0 \mathrm{~m}$

\section{Forest Interior and Width}

This data layer is comprised of unique aggregations of forest and non-forest map units taken from the Gap Analysis Project (GAP) land cover data. See above under Forest and Ecotone Habitats for descriptions of the forest and non-forest map units.

For a species that requires interior forest (for example, uses):

- Distances into forest from forest edge: 0; 30; 60; 120; 250; 500; 1,000; 2,000; 4,000; and >4,000 m 
For a species that avoids interior forest (for example, avoids):

- Distances away from forest from forest edge: $>4,000$; 4,000; 2,000; 1,000; 500; 250; 120; 60; 30; and $0 \mathrm{~m}$

\section{Human Impact Avoidance}

Environments dominated by human disturbance such as roads, cities, and the constructed materials that support human habitation have profound effects on species. For most species, this data layer was used to exclude species from a portion of the landscape. However, some species respond favorably to human habitats, therefore this data layer was used in an inclusionary manner. A species' model could have used the model variable for human impact avoidance at one of three avoidance levels described below:

- High-For species that are very intolerant of human disturbance. All portions of the landscape identified as being directly influenced by human disturbance are eliminated from the predicted distribution.

- Medium-For species that are moderately intolerant of human disturbance. Only portions of the landscape identified as being highly or moderately influenced by human disturbance are eliminated from the predicted distribution.

- Low-For species that are partially intolerant of human disturbance. Only portions of the landscape identified as being highly influenced by human disturbance are from the predicted distribution.

\section{Elevation}

Some species respond to environments directly related to altitudinal variation. Elevation (for example, a digital elevation model [DEM]) is easily implemented in spatial modeling by limiting the model to the minimum and maximum values explicitly stated in the literature. DEMs are utilized directly and are measured in meters above mean sea level.

\section{Hydrography}

Water and its location on the landscape is a very important aspect of species habitats. The source for hydrographic data was the USGS National Hydrography Dataset (NHD).

\section{Water Type}

- Flowing Water-Flowing water represents hydrographic features such as streams, rivers, springs, seeps, ditches with moving water, and so forth.
- Standing Water-Standing water represents hydrographic features such as lakes, ponds, reservoirs, bays, inlets, estuaries, ocean, ditches with non-flowing water, and so forth.

- Wet Vegetation-Wet vegetation represents hydrographic features such as swamps, marshes, Carolina bays, and so forth. This includes a collection of map units representing seasonally or tidally inundated woody and non-woody plants.

\section{Salinity}

Water salinity is a major factor when considering habitat conditions for many species. However, the dynamic and complex nature of water systems makes the development of a highly refined and reliable data layer challenging. Therefore, we developed three general categories to include in species habitat models for species requiring water:

- Freshwater Only

- Brackish/Saltwater Only

- All Water (that is, both brackish/saltwater and freshwater)

\section{Stream Velocity}

For some aquatic species, this is an important aspect of their habitat, such as oxygenation levels, presence of invertebrate prey, and amount of sediment within the water column and on streambed substrates. Stream velocity (that is, stream gradient) was derived from a combination of streams and slopes calculated from a DEM, which created three categories for stream gradient:

- Slow Only - For species that require slow moving or almost stagnant sections of streams or rivers. Typically, these are areas where the underlying topography is flat (0 percent gradient).

- Fast Only - For species that require high velocity sections of streams or rivers. Typically, these are areas where the underlying topography is steep. A threshold of $>5$ percent gradient was used.

- All Types - For species that can utilize either fast or slow sections of streams or rivers.

Distance into and from type of water:

- Distances from a type of water were: $>4,000 ; 4,000$; 2,000; 1,000; 500; 250; 120; 60; 30; and $0 \mathrm{~m}$

- Distances into a type of water were: $0 ; 30 ; 60 ; 120$; 250; 500; 1,000; 2,000; 4,000; and >4,000 m 
Table 1.1. List of 1,590 species for which Gap Analysis Project (GAP) habitat distribution models were created and combined to generate maps of species richness maps by class (amphibia, bird, mammal, reptile). Species listed alphabetically by taxa and scientific name.

[ITIS, Integrated Taxonomic Information System; TSN, taxonomic serial number]

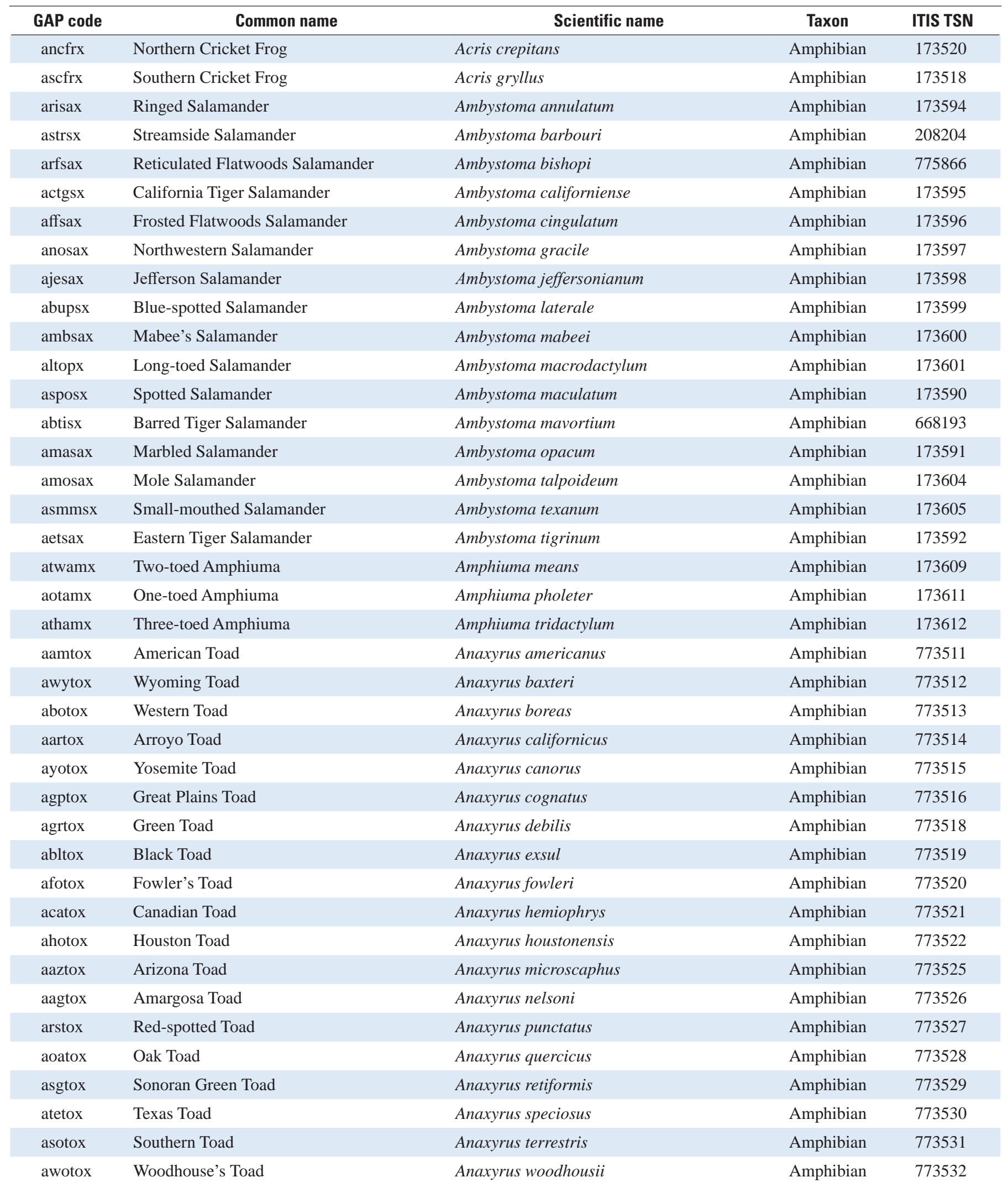


Table 1.1. List of 1,590 species for which Gap Analysis Project (GAP) habitat distribution models were created and combined to generate maps of species richness maps by class (amphibia, bird, mammal, reptile). Species listed alphabetically by taxa and scientific name.-Continued

[ITIS, Integrated Taxonomic Information System; TSN, taxonomic serial number]

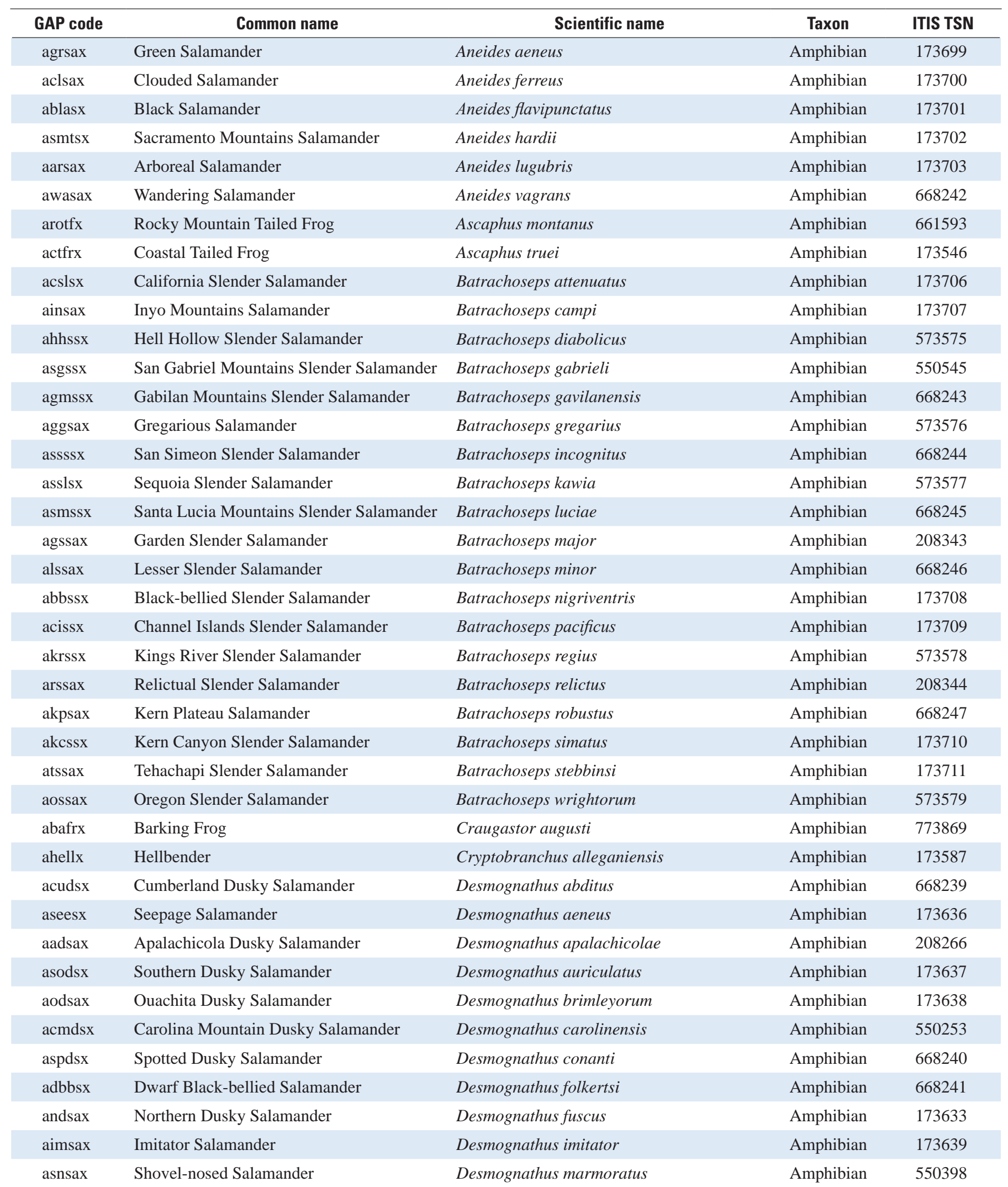


Table 1.1. List of 1,590 species for which Gap Analysis Project (GAP) habitat distribution models were created and combined to generate maps of species richness maps by class (amphibia, bird, mammal, reptile). Species listed alphabetically by taxa and scientific name.-Continued

[ITIS, Integrated Taxonomic Information System; TSN, taxonomic serial number]




Table 1.1. List of 1,590 species for which Gap Analysis Project (GAP) habitat distribution models were created and combined to generate maps of species richness maps by class (amphibia, bird, mammal, reptile). Species listed alphabetically by taxa and scientific name.-Continued

[ITIS, Integrated Taxonomic Information System; TSN, taxonomic serial number]

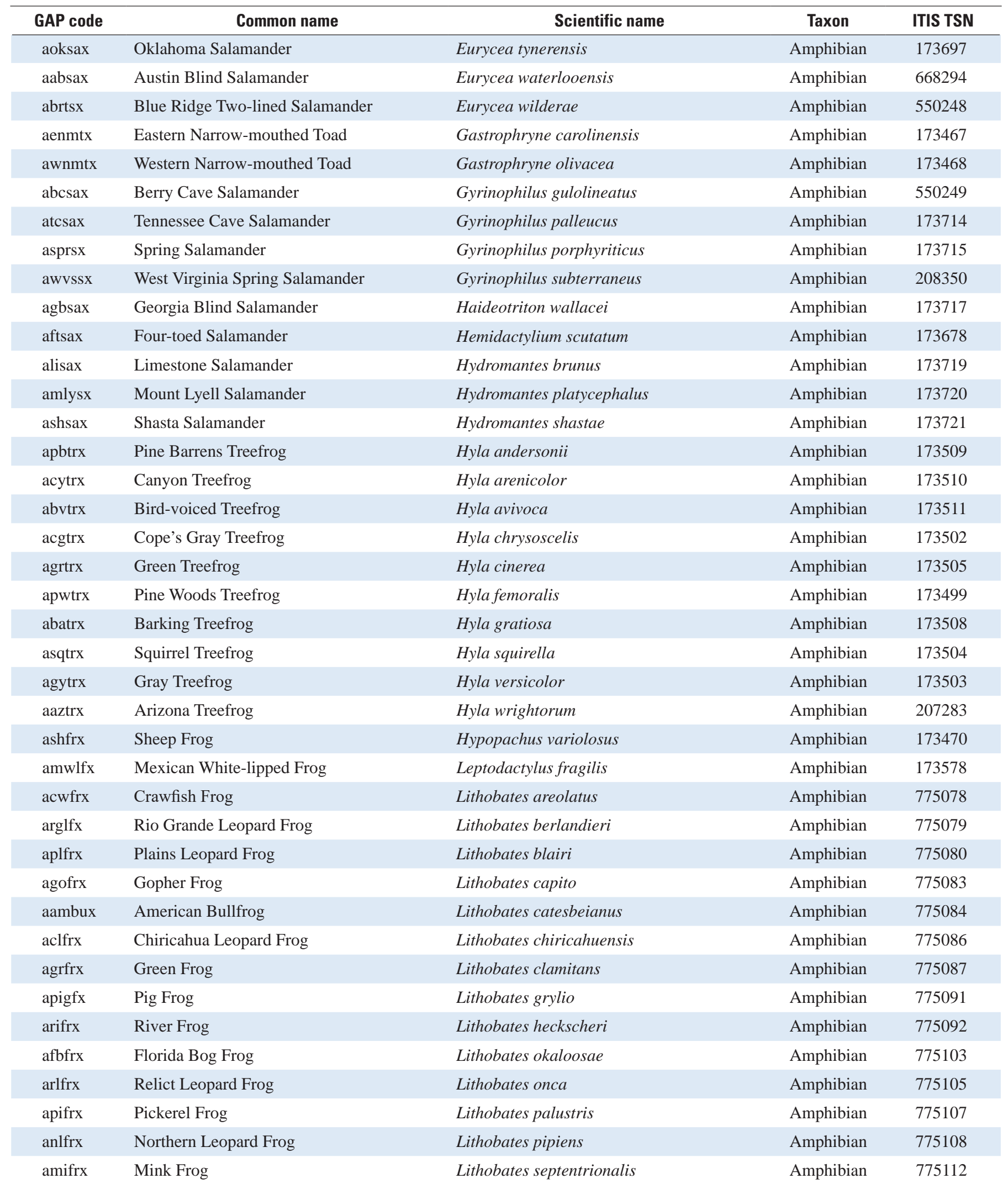


Table 1.1. List of 1,590 species for which Gap Analysis Project (GAP) habitat distribution models were created and combined to generate maps of species richness maps by class (amphibia, bird, mammal, reptile). Species listed alphabetically by taxa and scientific name.-Continued

[ITIS, Integrated Taxonomic Information System; TSN, taxonomic serial number]

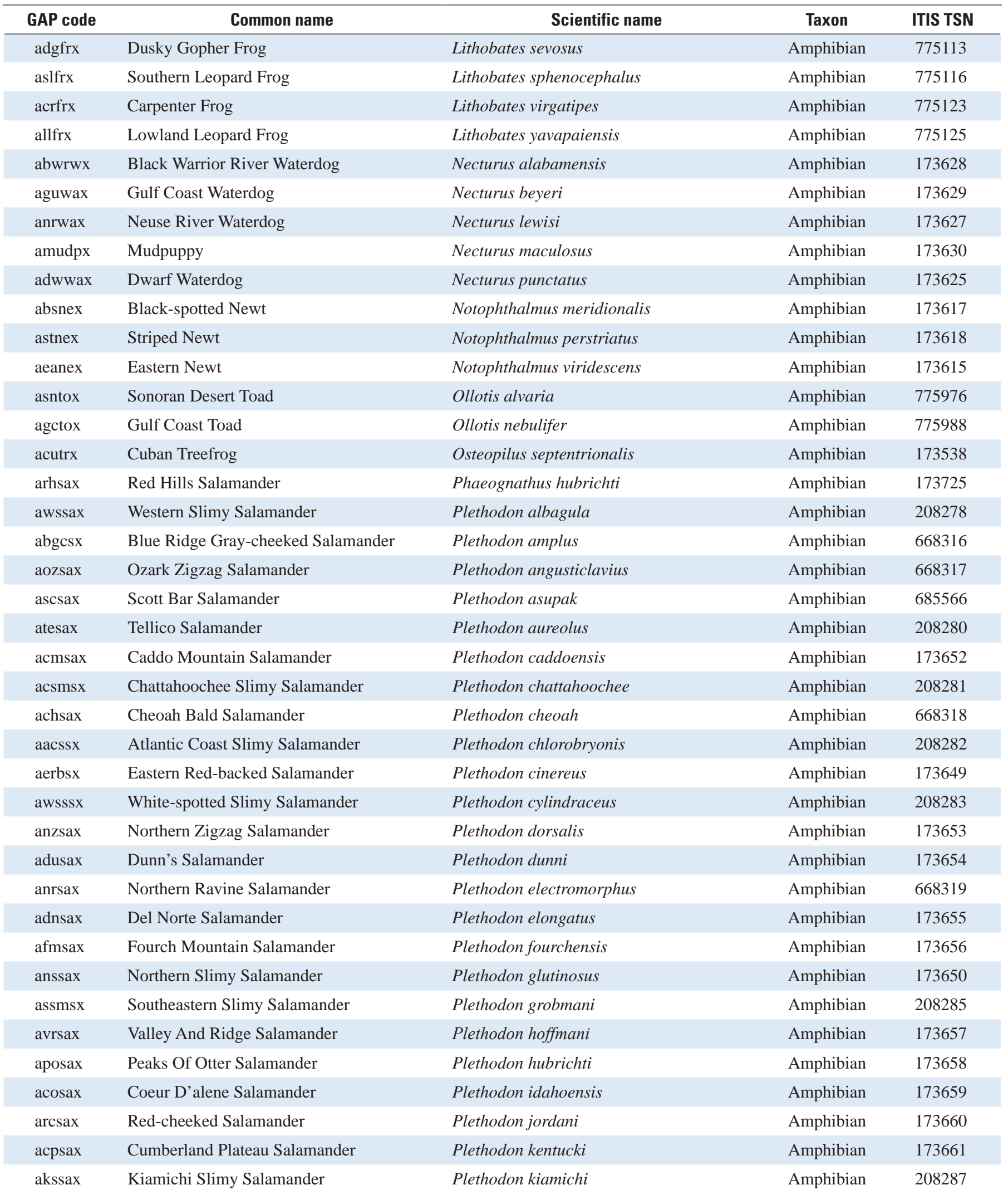


Table 1.1. List of 1,590 species for which Gap Analysis Project (GAP) habitat distribution models were created and combined to generate maps of species richness maps by class (amphibia, bird, mammal, reptile). Species listed alphabetically by taxa and scientific name.-Continued

[ITIS, Integrated Taxonomic Information System; TSN, taxonomic serial number]

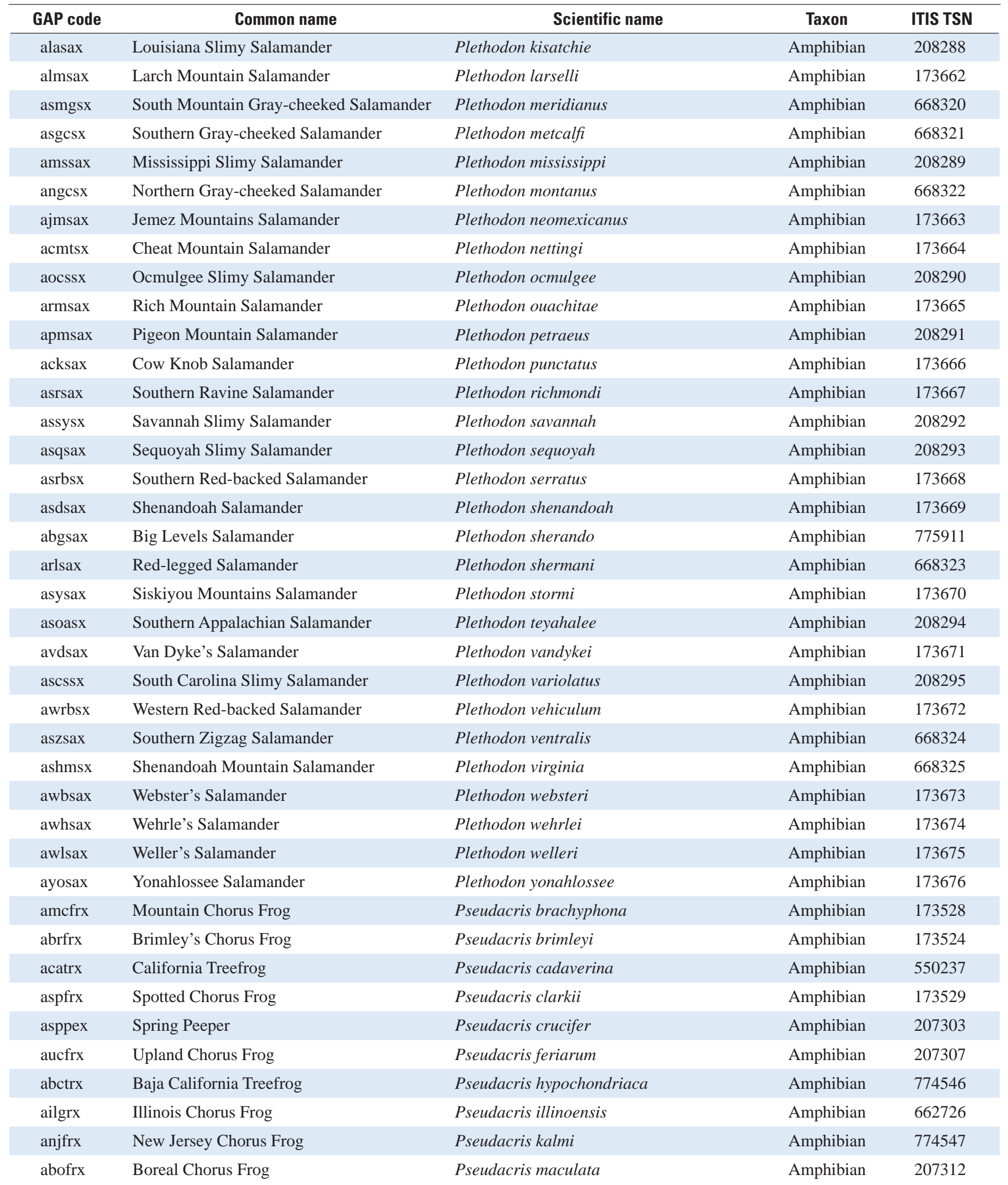


Table 1.1. List of 1,590 species for which Gap Analysis Project (GAP) habitat distribution models were created and combined to generate maps of species richness maps by class (amphibia, bird, mammal, reptile). Species listed alphabetically by taxa and scientific name.-Continued

[ITIS, Integrated Taxonomic Information System; TSN, taxonomic serial number]

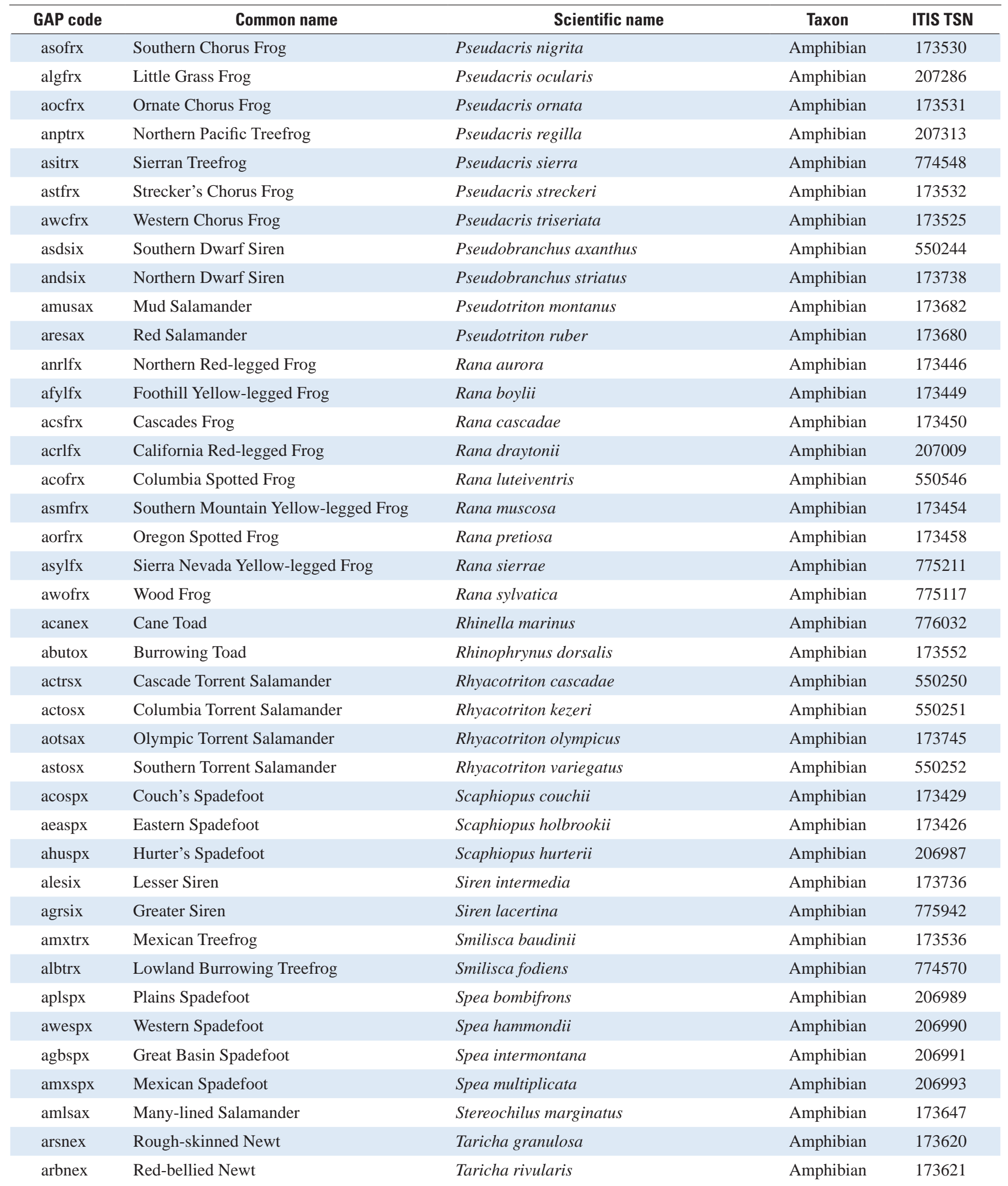


Table 1.1. List of 1,590 species for which Gap Analysis Project (GAP) habitat distribution models were created and combined to generate maps of species richness maps by class (amphibia, bird, mammal, reptile). Species listed alphabetically by taxa and scientific name.-Continued

[ITIS, Integrated Taxonomic Information System; TSN, taxonomic serial number]

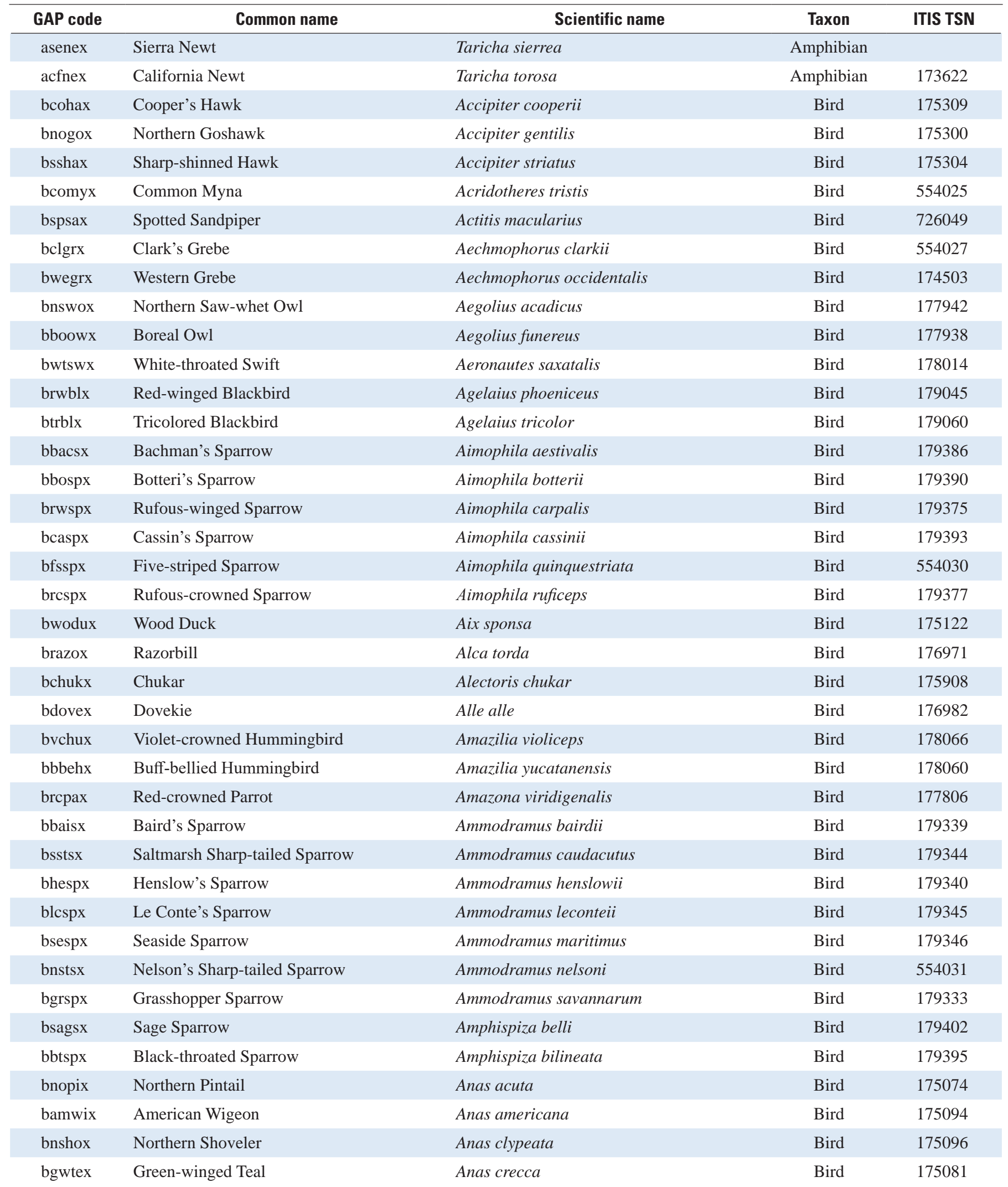


Table 1.1. List of 1,590 species for which Gap Analysis Project (GAP) habitat distribution models were created and combined to generate maps of species richness maps by class (amphibia, bird, mammal, reptile). Species listed alphabetically by taxa and scientific name.-Continued

[ITIS, Integrated Taxonomic Information System; TSN, taxonomic serial number]

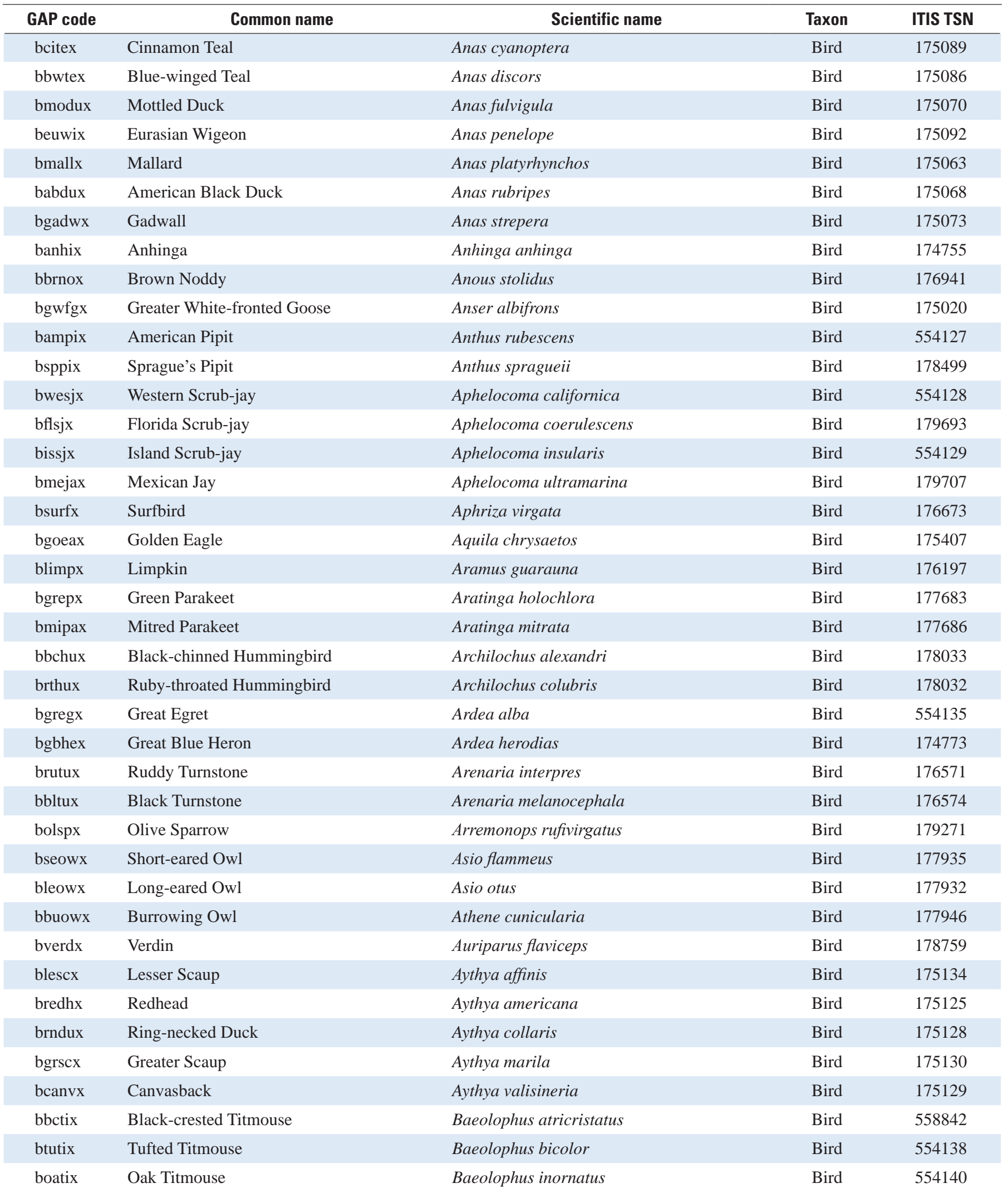


Table 1.1. List of 1,590 species for which Gap Analysis Project (GAP) habitat distribution models were created and combined to generate maps of species richness maps by class (amphibia, bird, mammal, reptile). Species listed alphabetically by taxa and scientific name.-Continued

[ITIS, Integrated Taxonomic Information System; TSN, taxonomic serial number]

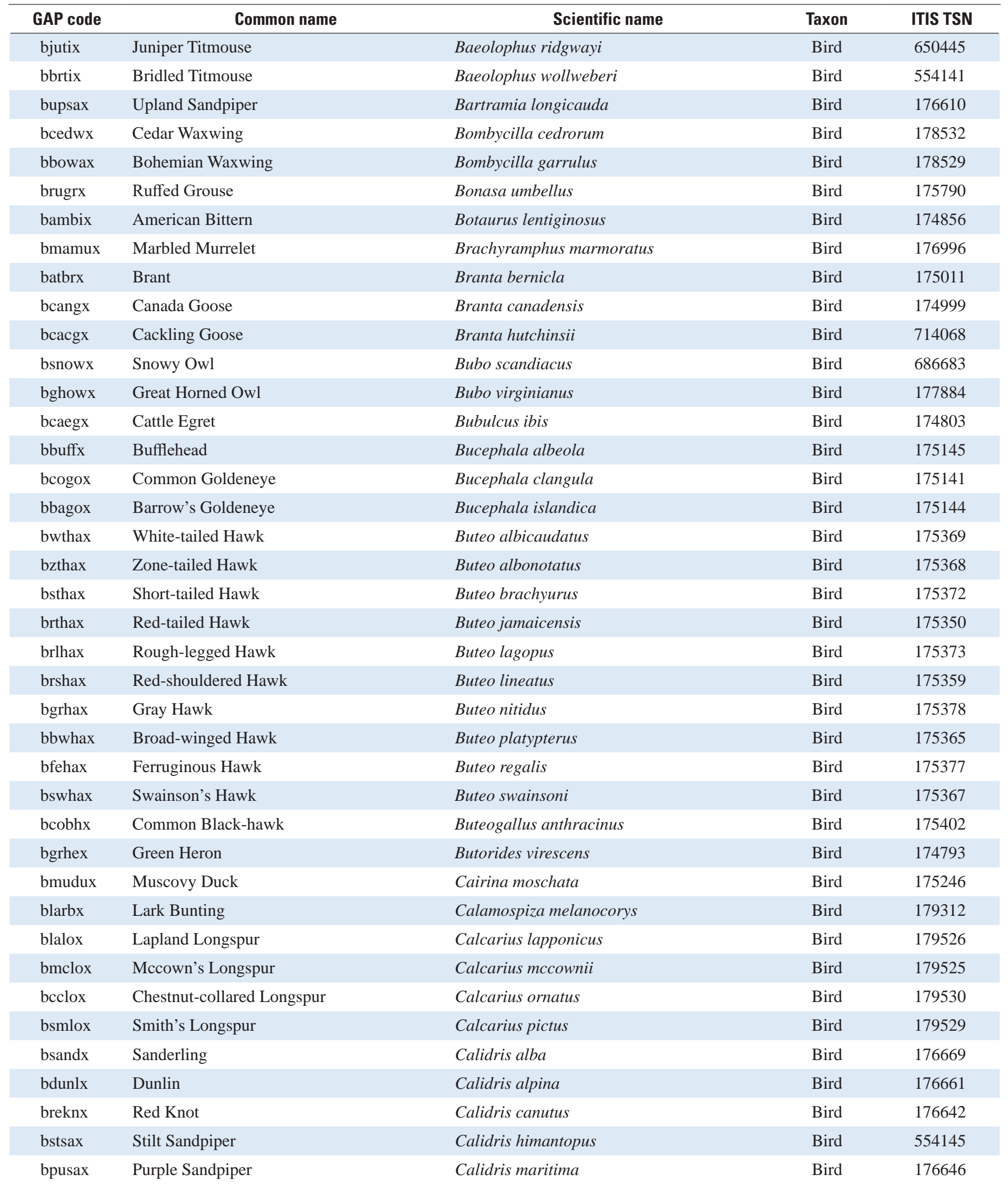


Table 1.1. List of 1,590 species for which Gap Analysis Project (GAP) habitat distribution models were created and combined to generate maps of species richness maps by class (amphibia, bird, mammal, reptile). Species listed alphabetically by taxa and scientific name.-Continued

[ITIS, Integrated Taxonomic Information System; TSN, taxonomic serial number]

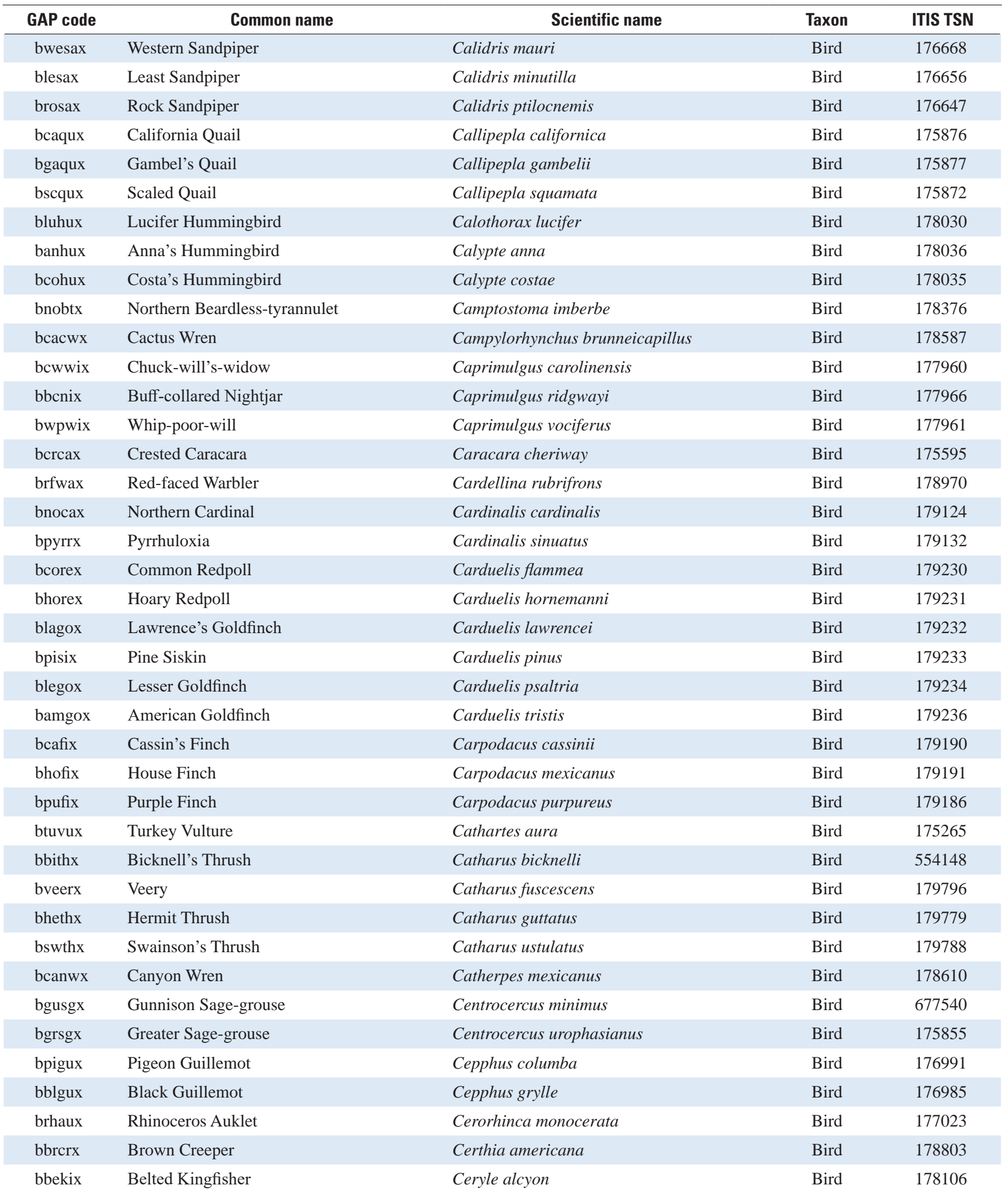


Table 1.1. List of 1,590 species for which Gap Analysis Project (GAP) habitat distribution models were created and combined to generate maps of species richness maps by class (amphibia, bird, mammal, reptile). Species listed alphabetically by taxa and scientific name.-Continued

[ITIS, Integrated Taxonomic Information System; TSN, taxonomic serial number]

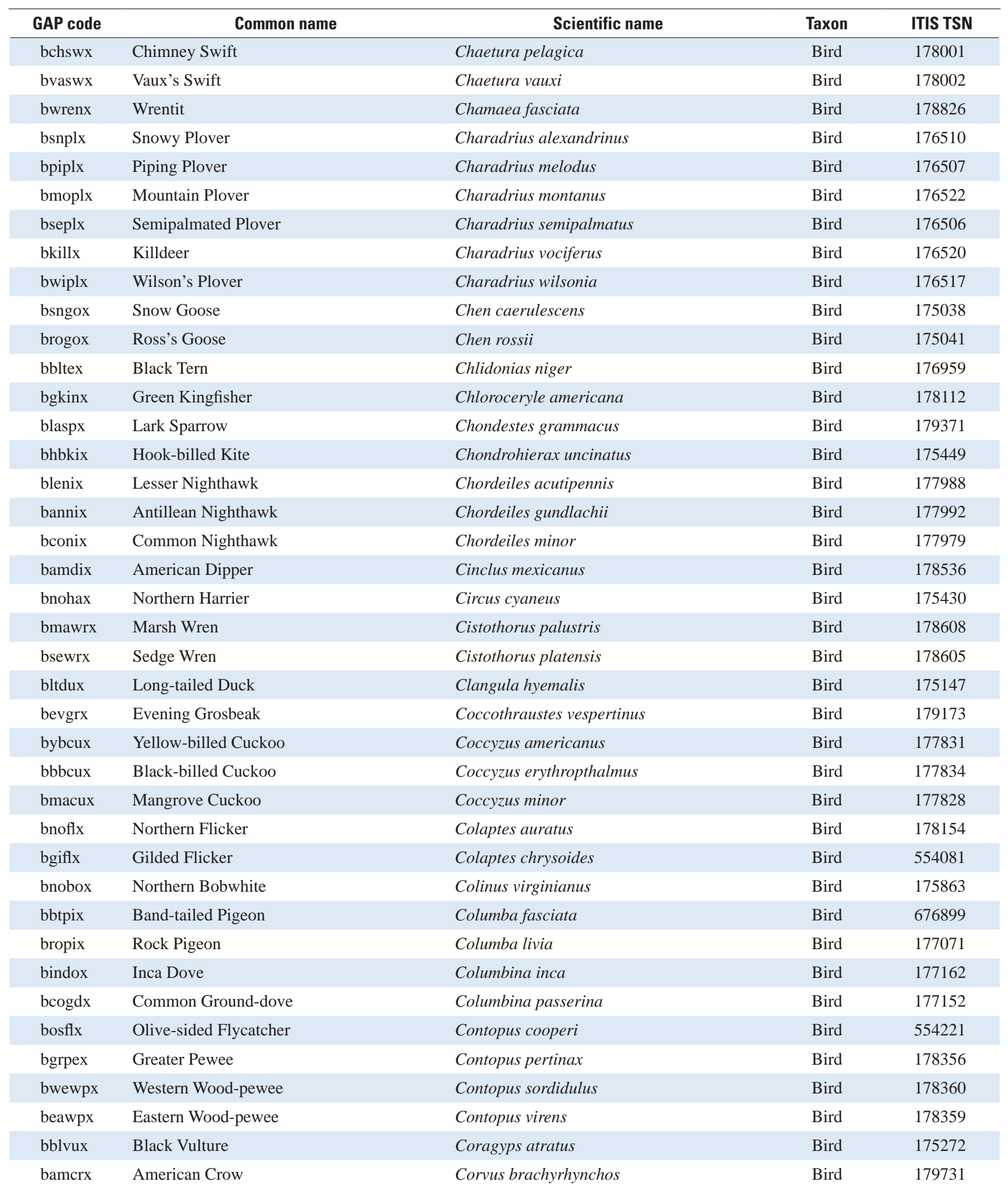


Table 1.1. List of 1,590 species for which Gap Analysis Project (GAP) habitat distribution models were created and combined to generate maps of species richness maps by class (amphibia, bird, mammal, reptile). Species listed alphabetically by taxa and scientific name.-Continued

[ITIS, Integrated Taxonomic Information System; TSN, taxonomic serial number]

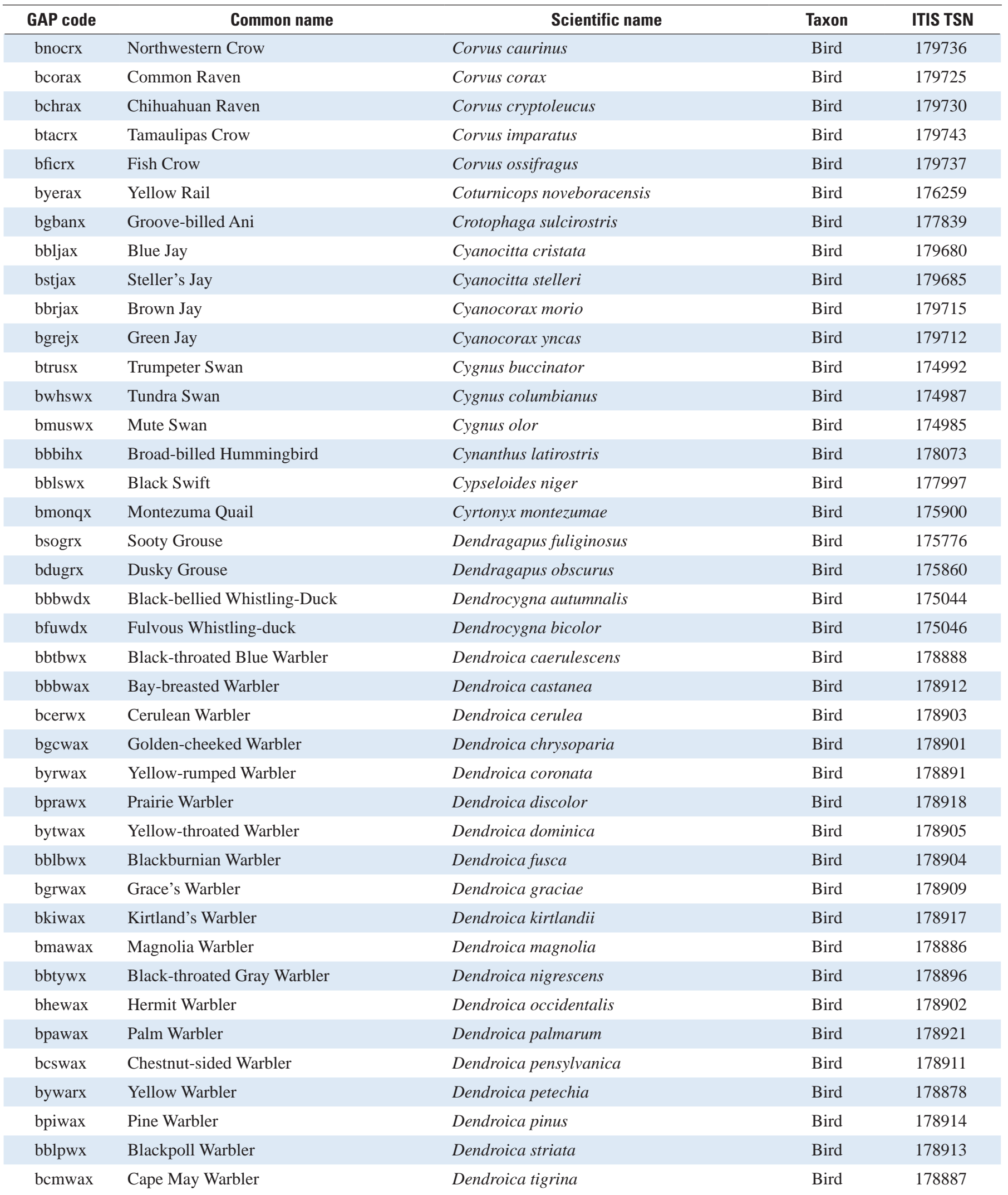


Table 1.1. List of 1,590 species for which Gap Analysis Project (GAP) habitat distribution models were created and combined to generate maps of species richness maps by class (amphibia, bird, mammal, reptile). Species listed alphabetically by taxa and scientific name.-Continued

[ITIS, Integrated Taxonomic Information System; TSN, taxonomic serial number]

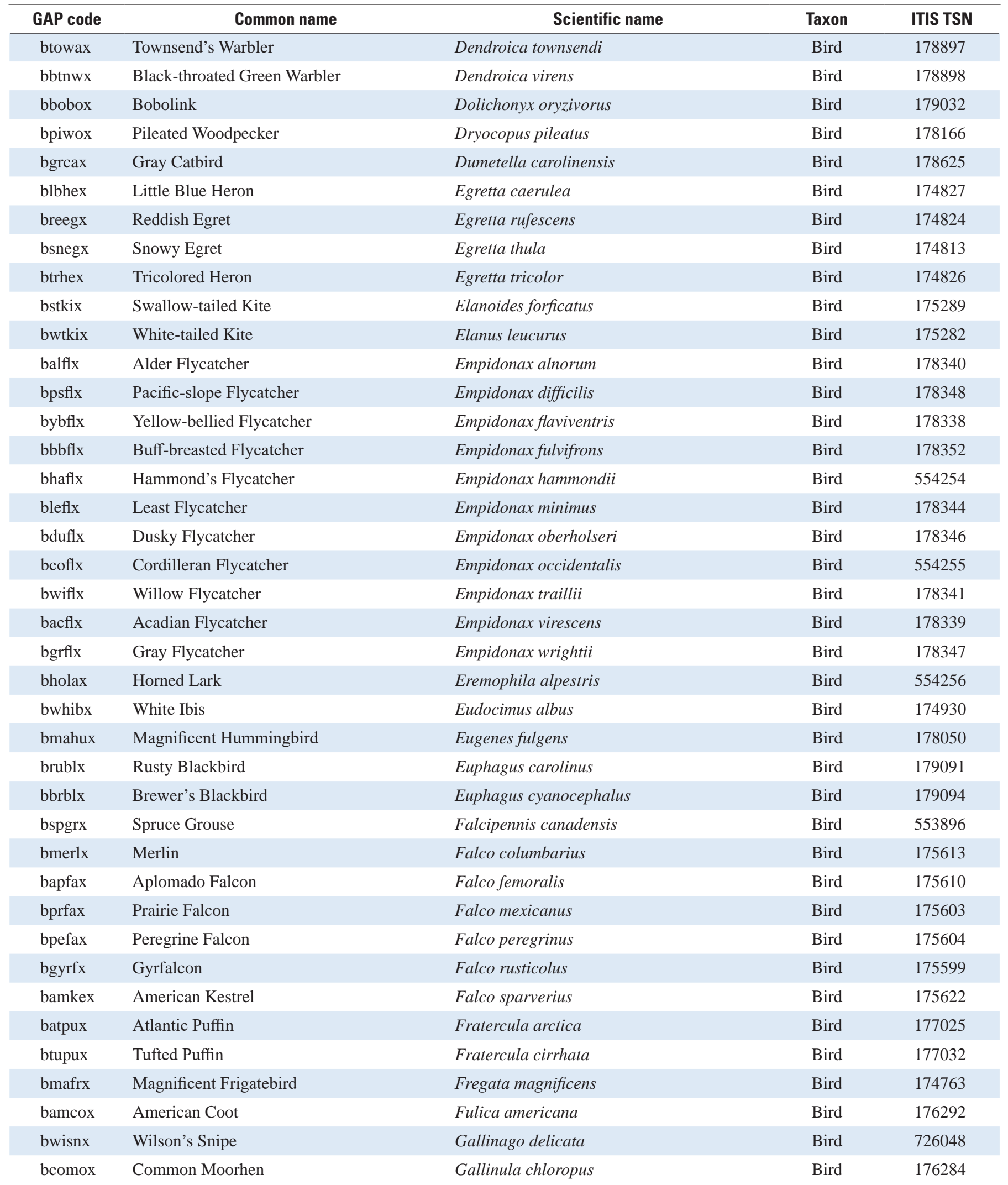


Table 1.1. List of 1,590 species for which Gap Analysis Project (GAP) habitat distribution models were created and combined to generate maps of species richness maps by class (amphibia, bird, mammal, reptile). Species listed alphabetically by taxa and scientific name.-Continued

[ITIS, Integrated Taxonomic Information System; TSN, taxonomic serial number]

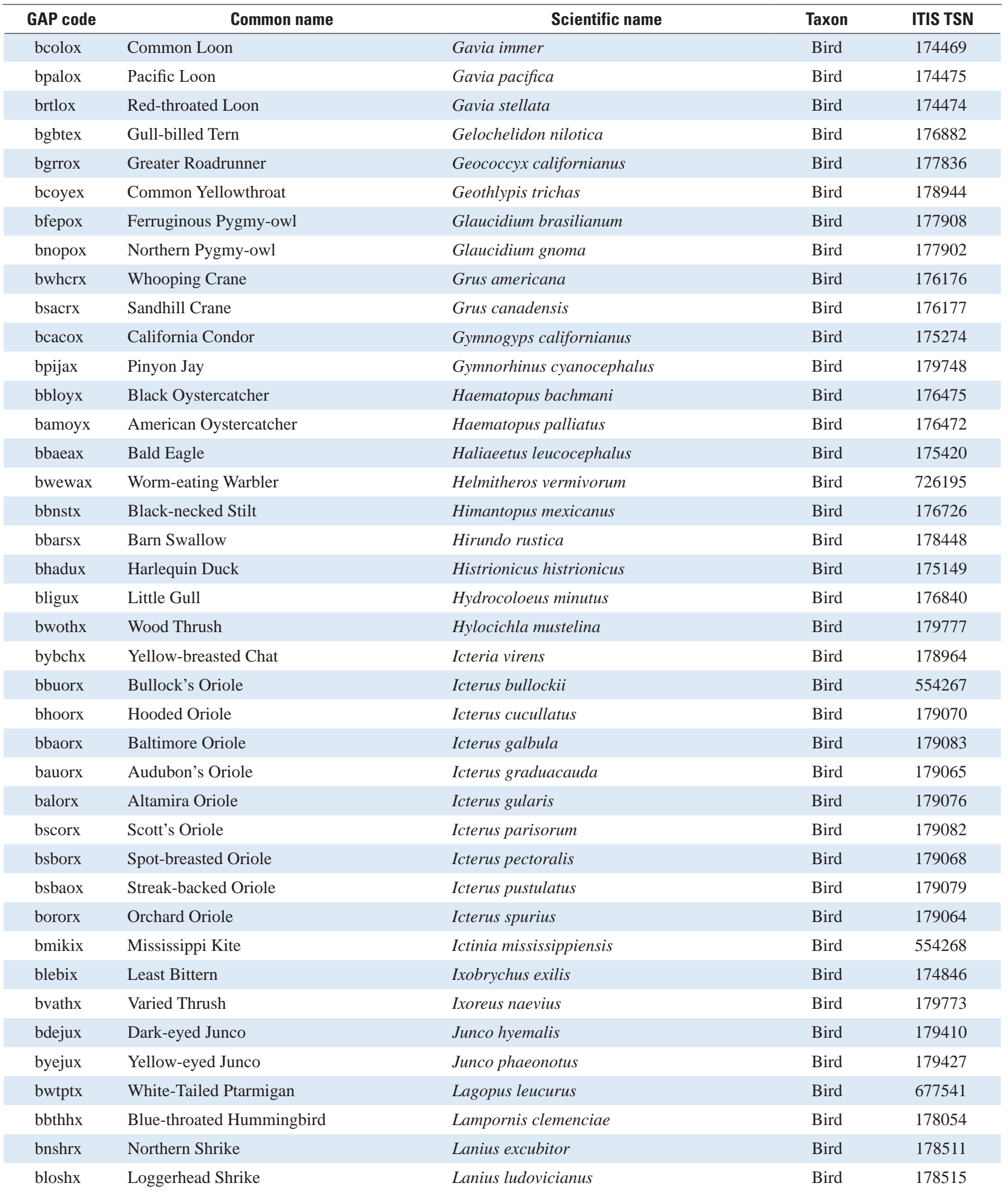


Table 1.1. List of 1,590 species for which Gap Analysis Project (GAP) habitat distribution models were created and combined to generate maps of species richness maps by class (amphibia, bird, mammal, reptile). Species listed alphabetically by taxa and scientific name.-Continued

[ITIS, Integrated Taxonomic Information System; TSN, taxonomic serial number]

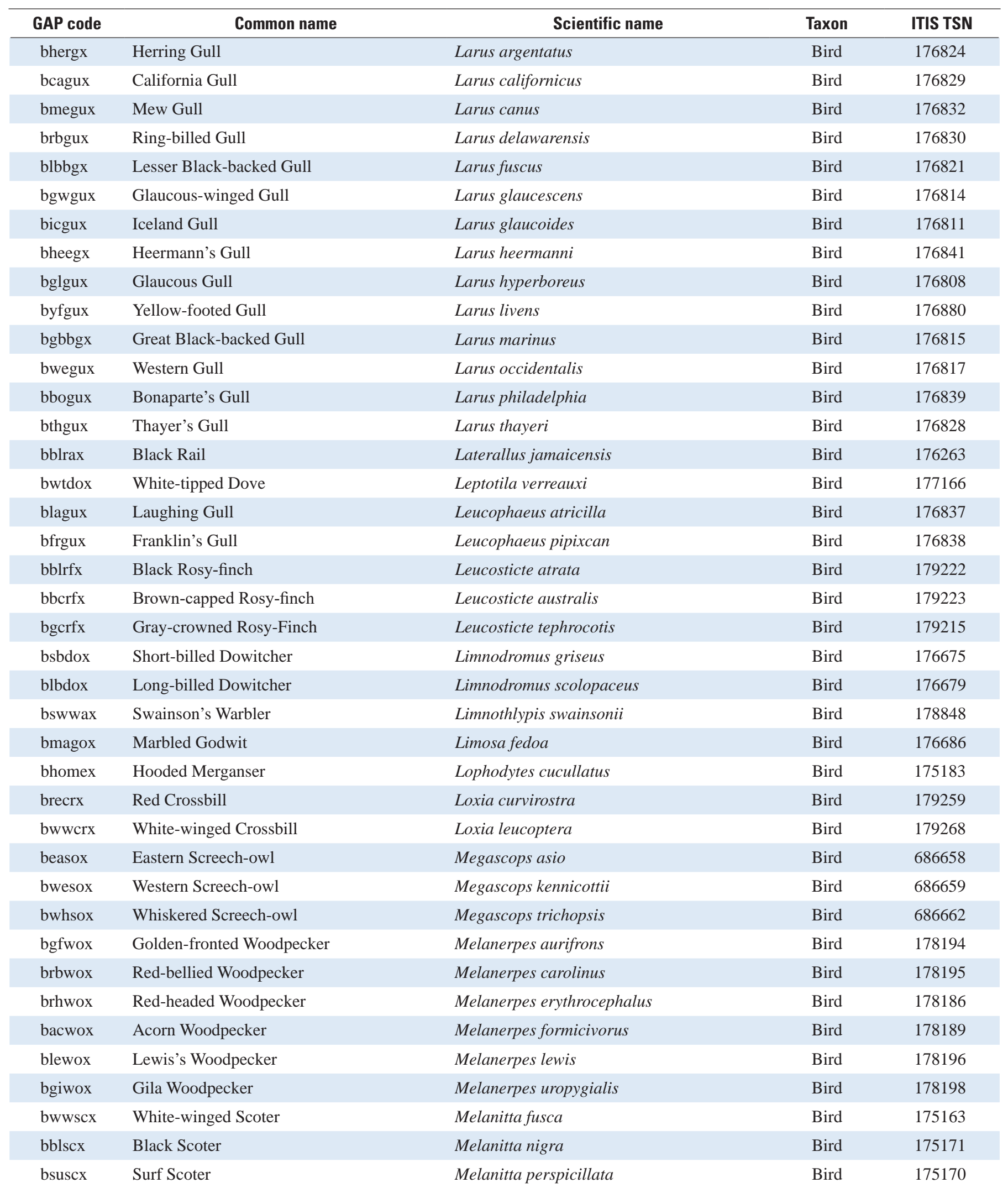


Table 1.1. List of 1,590 species for which Gap Analysis Project (GAP) habitat distribution models were created and combined to generate maps of species richness maps by class (amphibia, bird, mammal, reptile). Species listed alphabetically by taxa and scientific name.-Continued

[ITIS, Integrated Taxonomic Information System; TSN, taxonomic serial number]

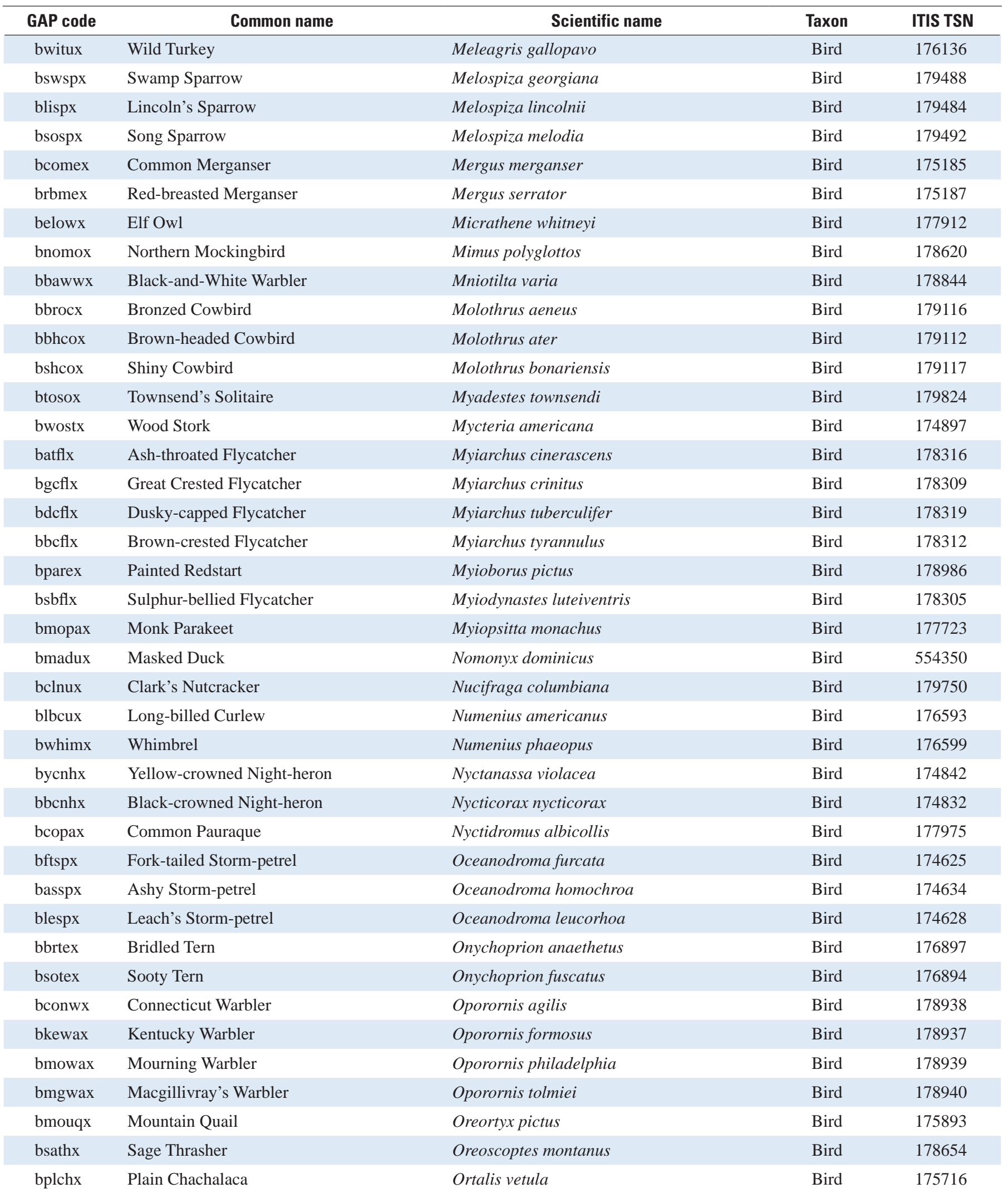


Table 1.1. List of 1,590 species for which Gap Analysis Project (GAP) habitat distribution models were created and combined to generate maps of species richness maps by class (amphibia, bird, mammal, reptile). Species listed alphabetically by taxa and scientific name.-Continued

[ITIS, Integrated Taxonomic Information System; TSN, taxonomic serial number]

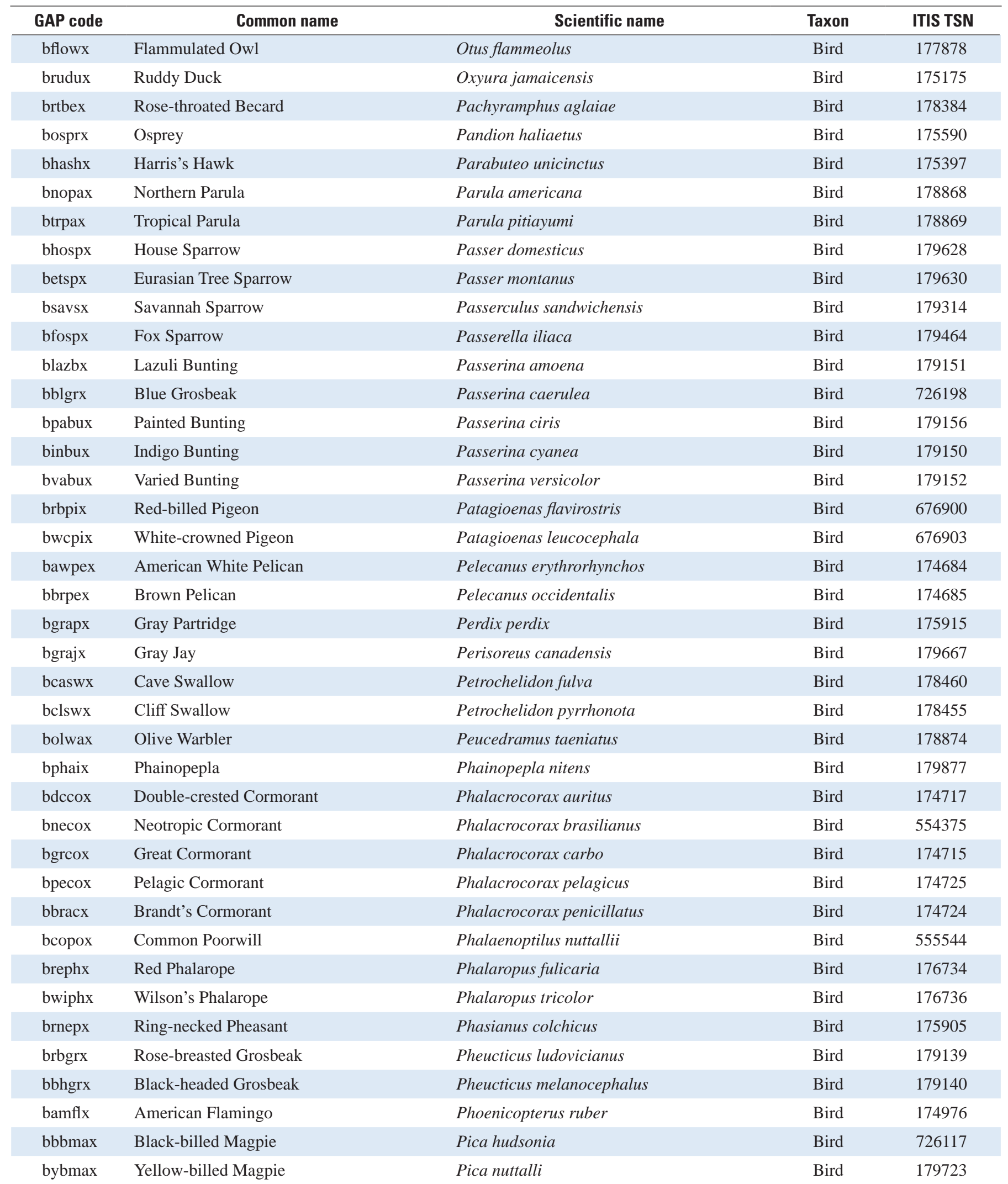


Table 1.1. List of 1,590 species for which Gap Analysis Project (GAP) habitat distribution models were created and combined to generate maps of species richness maps by class (amphibia, bird, mammal, reptile). Species listed alphabetically by taxa and scientific name.-Continued

[ITIS, Integrated Taxonomic Information System; TSN, taxonomic serial number]

\begin{tabular}{|c|c|c|c|c|}
\hline GAP code & Common name & Scientific name & Taxon & ITIS TSN \\
\hline bwhwox & White-headed Woodpecker & Picoides albolarvatus & Bird & 178256 \\
\hline bbbwox & Black-backed Woodpecker & Picoides arcticus & Bird & 178250 \\
\hline barwox & Arizona Woodpecker & Picoides arizonae & Bird & 685724 \\
\hline brcwox & Red-cockaded Woodpecker & Picoides borealis & Bird & 178257 \\
\hline bnuwox & Nuttall’s Woodpecker & Picoides nuttallii & Bird & 178258 \\
\hline bdowox & Downy Woodpecker & Picoides pubescens & Bird & 178259 \\
\hline blbwox & Ladder-backed Woodpecker & Picoides scalaris & Bird & 178260 \\
\hline battwx & American Three-toed Woodpecker & Picoides tridactylus & Bird & 685725 \\
\hline bhawox & Hairy Woodpecker & Picoides villosus & Bird & 178262 \\
\hline bpigrx & Pine Grosbeak & Pinicola enucleator & Bird & 179205 \\
\hline babtox & Abert's Towhee & Pipilo aberti & Bird & 179307 \\
\hline bgttox & Green-tailed Towhee & Pipilo chlorurus & Bird & 179310 \\
\hline bcaltx & California Towhee & Pipilo crissalis & Bird & 202307 \\
\hline beatox & Eastern Towhee & Pipilo erythrophthalmus & Bird & 179276 \\
\hline bcantx & Canyon Towhee & Pipilo fuscus & Bird & 179293 \\
\hline bsptox & Spotted Towhee & Pipilo maculatus & Bird & 554380 \\
\hline bhetax & Hepatic Tanager & Piranga flava & Bird & 179884 \\
\hline bwetax & Western Tanager & Piranga ludoviciana & Bird & 179882 \\
\hline bsctax & Scarlet Tanager & Piranga olivacea & Bird & 179883 \\
\hline bsutax & Summer Tanager & Piranga rubra & Bird & 179888 \\
\hline bgkisx & Great Kiskadee & Pitangus sulphuratus & Bird & 178301 \\
\hline brospx & Roseate Spoonbill & Platalea ajaja & Bird & 174941 \\
\hline bsnbux & Snow Bunting & Plectrophenax nivalis & Bird & 179532 \\
\hline bwfibx & White-faced Ibis & Plegadis chihi & Bird & 174926 \\
\hline bglibx & Glossy Ibis & Plegadis falcinellus & Bird & 174924 \\
\hline bpagpx & Pacific Golden-plover & Pluvialis fulva & Bird & 554381 \\
\hline bbbplx & Black-bellied Plover & Pluvialis squatarola & Bird & 176567 \\
\hline bhogrx & Horned Grebe & Podiceps auritus & Bird & 174482 \\
\hline brngrx & Red-necked Grebe & Podiceps grisegena & Bird & 174479 \\
\hline beagrx & Eared Grebe & Podiceps nigricollis & Bird & 174485 \\
\hline bpbgrx & Pied-billed Grebe & Podilymbus podiceps & Bird & 174505 \\
\hline bbcchx & Black-capped Chickadee & Poecile atricapilla & Bird & 554382 \\
\hline bcachx & Carolina Chickadee & Poecile carolinensis & Bird & 554383 \\
\hline bmochx & Mountain Chickadee & Poecile gambeli & Bird & 554385 \\
\hline bbochx & Boreal Chickadee & Poecile hudsonica & Bird & 726112 \\
\hline bcbchx & Chestnut-backed Chickadee & Poecile rufescens & Bird & 554387 \\
\hline bmechx & Mexican Chickadee & Poecile sclateri & Bird & 554388 \\
\hline bbggnx & Blue-gray Gnatcatcher & Polioptila caerulea & Bird & 179853 \\
\hline bcagnx & California Gnatcatcher & Polioptila californica & Bird & 554389 \\
\hline bbtgnx & Black-tailed Gnatcatcher & Polioptila melanura & Bird & 179857 \\
\hline
\end{tabular}


Table 1.1. List of 1,590 species for which Gap Analysis Project (GAP) habitat distribution models were created and combined to generate maps of species richness maps by class (amphibia, bird, mammal, reptile). Species listed alphabetically by taxa and scientific name.-Continued

[ITIS, Integrated Taxonomic Information System; TSN, taxonomic serial number]

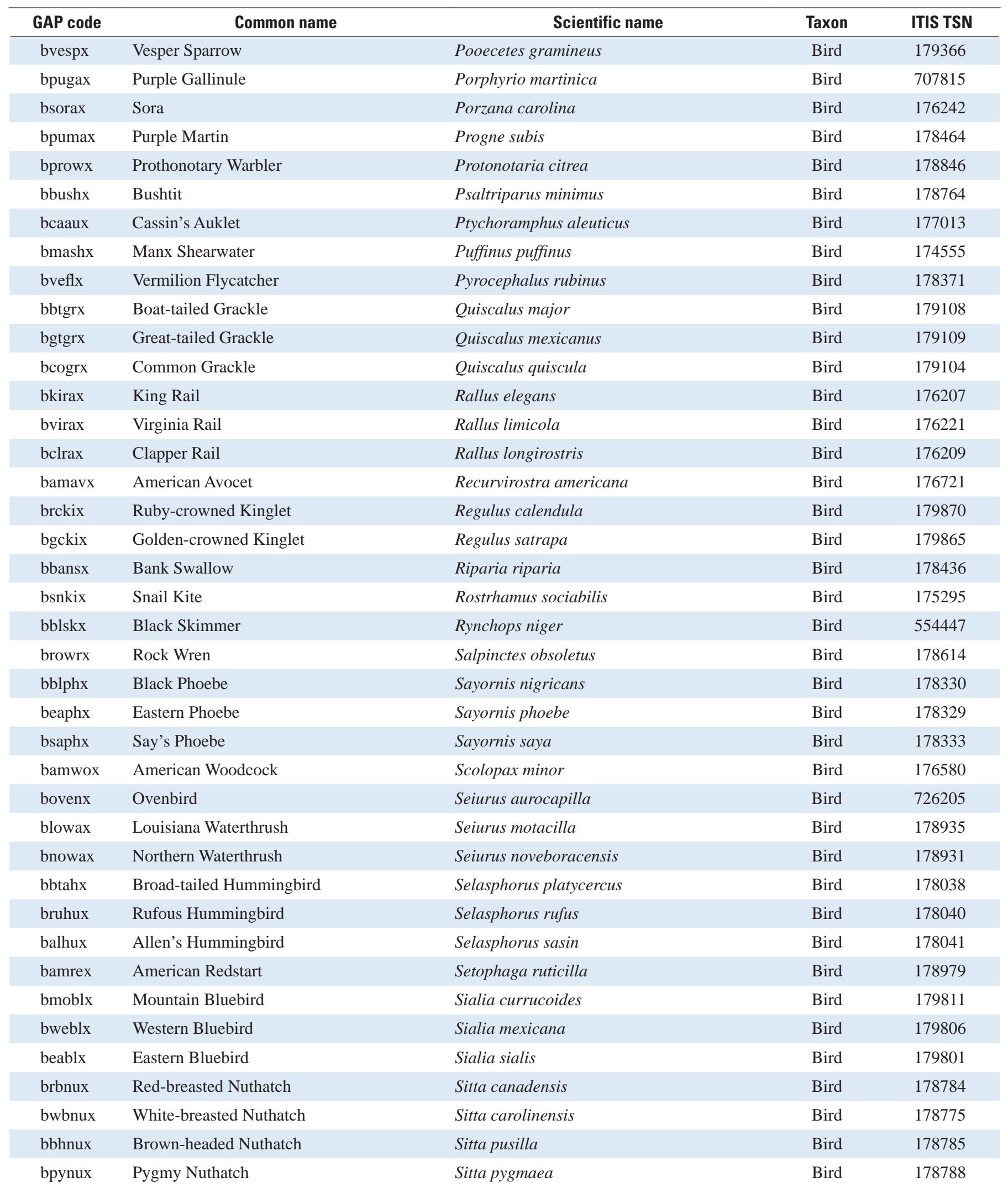


Table 1.1. List of 1,590 species for which Gap Analysis Project (GAP) habitat distribution models were created and combined to generate maps of species richness maps by class (amphibia, bird, mammal, reptile). Species listed alphabetically by taxa and scientific name.-Continued

[ITIS, Integrated Taxonomic Information System; TSN, taxonomic serial number]

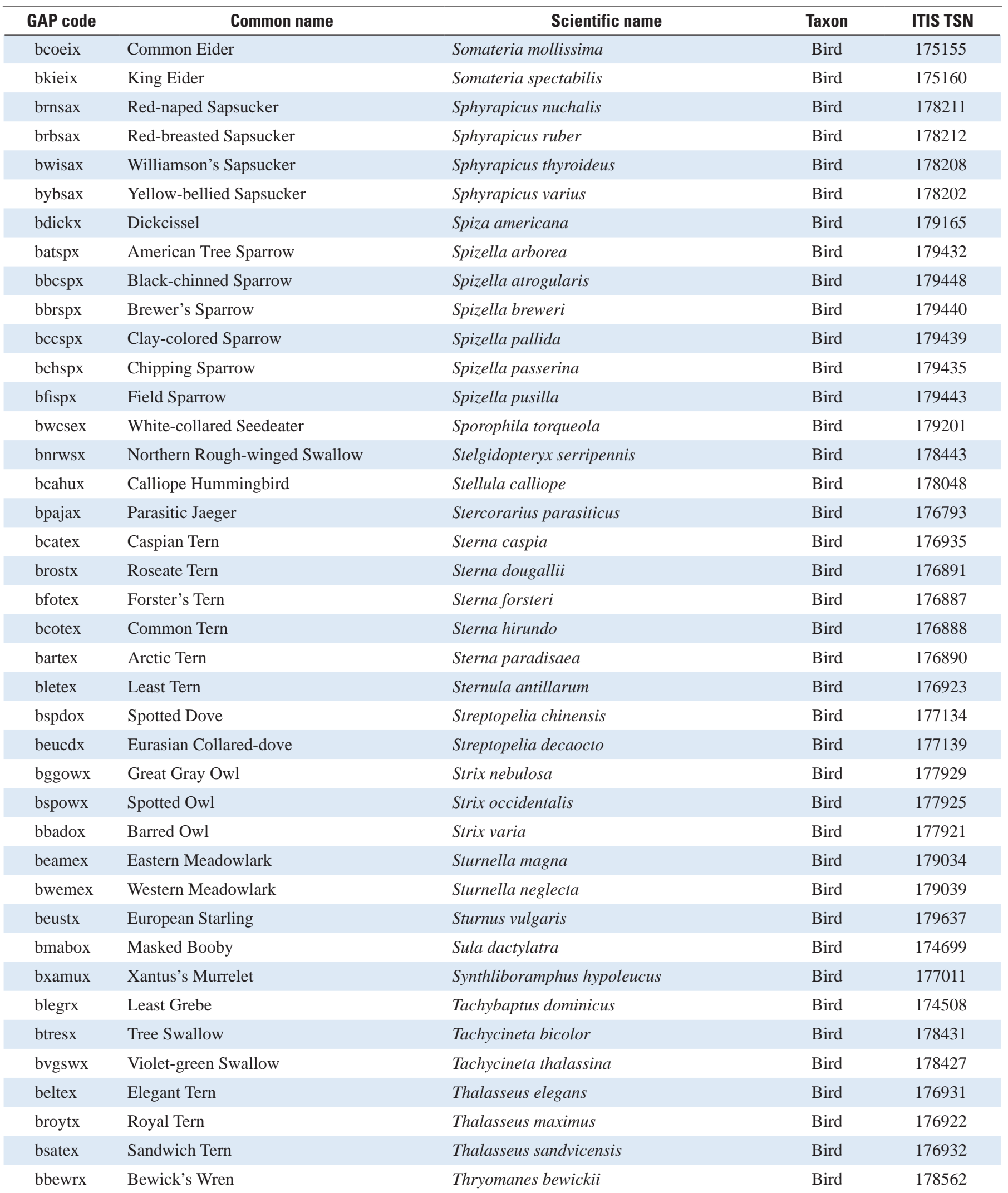


Table 1.1. List of 1,590 species for which Gap Analysis Project (GAP) habitat distribution models were created and combined to generate maps of species richness maps by class (amphibia, bird, mammal, reptile). Species listed alphabetically by taxa and scientific name.-Continued

[ITIS, Integrated Taxonomic Information System; TSN, taxonomic serial number]

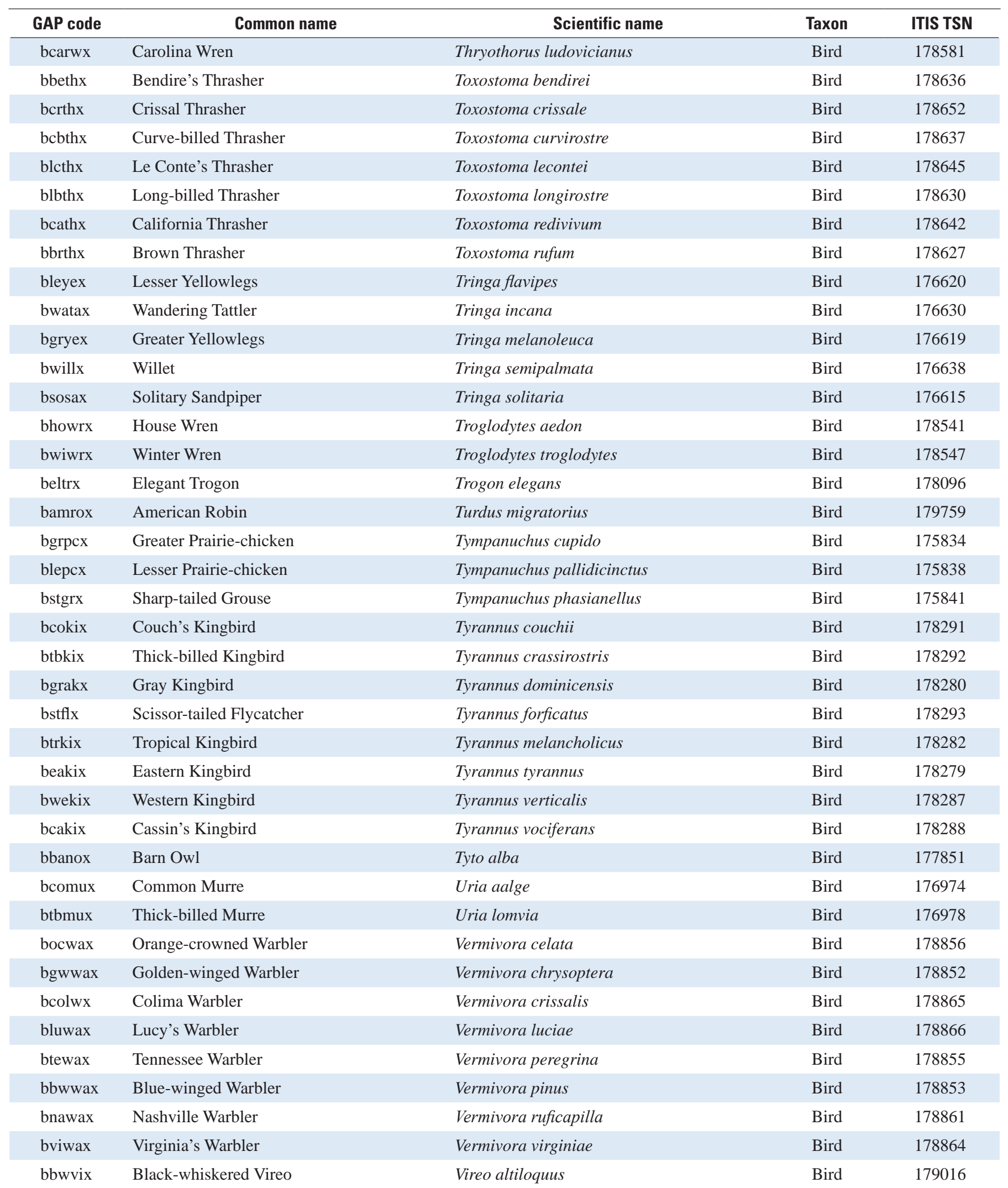


Table 1.1. List of 1,590 species for which Gap Analysis Project (GAP) habitat distribution models were created and combined to generate maps of species richness maps by class (amphibia, bird, mammal, reptile). Species listed alphabetically by taxa and scientific name.-Continued

[ITIS, Integrated Taxonomic Information System; TSN, taxonomic serial number]

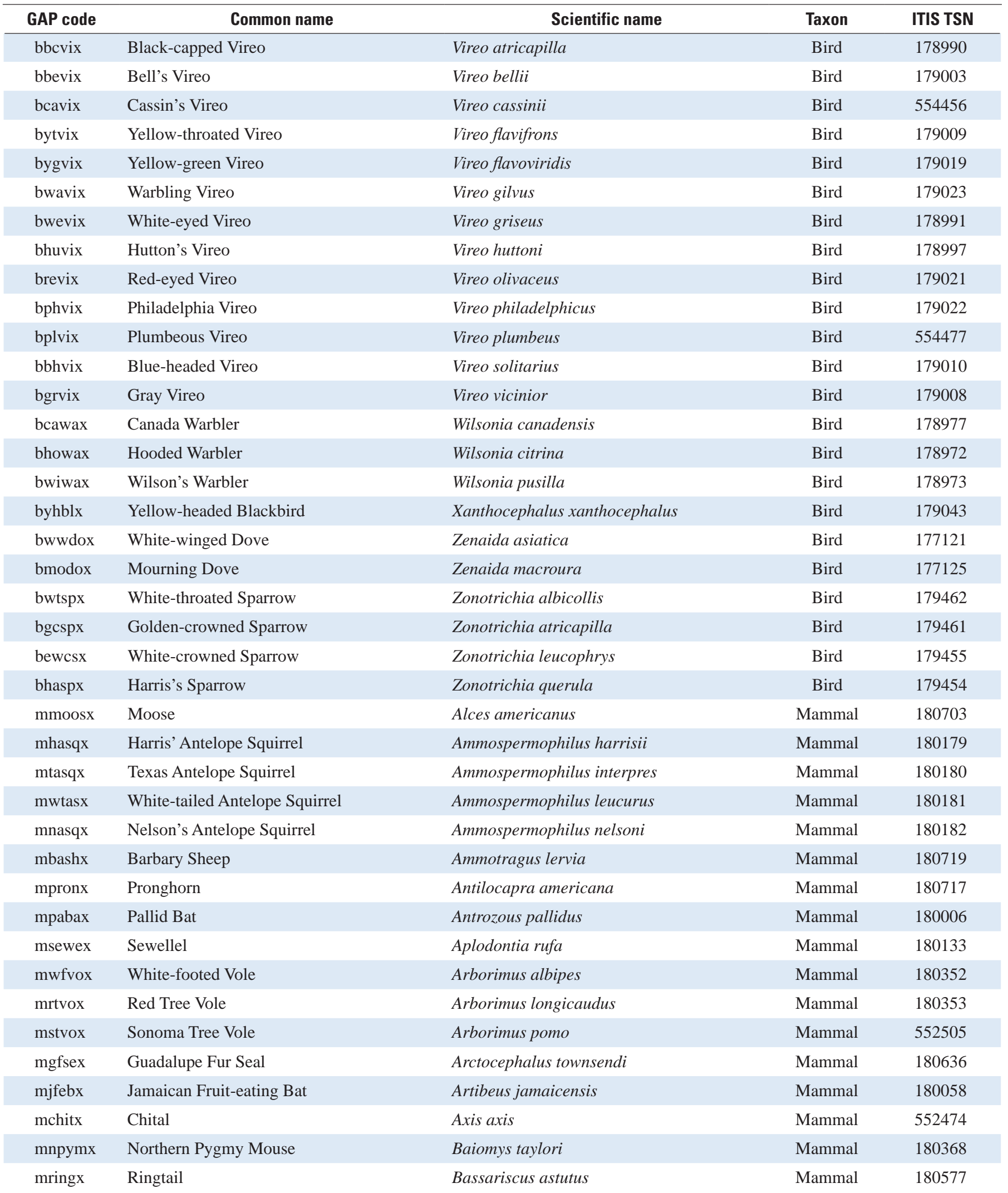


Table 1.1. List of 1,590 species for which Gap Analysis Project (GAP) habitat distribution models were created and combined to generate maps of species richness maps by class (amphibia, bird, mammal, reptile). Species listed alphabetically by taxa and scientific name.-Continued

[ITIS, Integrated Taxonomic Information System; TSN, taxonomic serial number]




Table 1.1. List of 1,590 species for which Gap Analysis Project (GAP) habitat distribution models were created and combined to generate maps of species richness maps by class (amphibia, bird, mammal, reptile). Species listed alphabetically by taxa and scientific name.-Continued

[ITIS, Integrated Taxonomic Information System; TSN, taxonomic serial number]

\begin{tabular}{|c|c|c|c|c|}
\hline GAP code & Common name & Scientific name & Taxon & ITIS TSN \\
\hline mtkrax & Texas Kangaroo Rat & Dipodomys elator & Mammal & 180237 \\
\hline mhkrax & Heermann's Kangaroo Rat & Dipodomys heermanni & Mammal & 180239 \\
\hline mmkrax & Merriam’s Kangaroo Rat & Dipodomys merriami & Mammal & 180241 \\
\hline mctkrx & Chisel-toothed Kangaroo Rat & Dipodomys microps & Mammal & 180242 \\
\hline mokrax & Ord’s Kangaroo Rat & Dipodomys ordii & Mammal & 180244 \\
\hline mpkrax & Panamint Kangaroo Rat & Dipodomys panamintinus & Mammal & 180245 \\
\hline mdzrax & Dulzura Kangaroo Rat & Dipodomys simulans & Mammal & 555660 \\
\hline mbtkrx & Banner-tailed Kangaroo Rat & Dipodomys spectabilis & Mammal & 180246 \\
\hline mbbbax & Big Brown Bat & Eptesicus fuscus & Mammal & 180008 \\
\hline mhorsx & Horse & Equus caballus & Mammal & 180691 \\
\hline mnapox & North American Porcupine & Erethizon dorsatum & Mammal & 180393 \\
\hline mspbax & Spotted Bat & Euderma maculatum & Mammal & 180010 \\
\hline msslix & Steller Sea Lion & Eumetopias jubatus & Mammal & 180625 \\
\hline mfbbax & Florida Bonneted Bat & Eumops floridanus & Mammal & 946276 \\
\hline mwbbax & Wagner’s Bonneted Bat & Eumops glaucinus & Mammal & 180079 \\
\hline mgbbax & Greater Bonneted Bat & Eumops perotis & Mammal & 180080 \\
\hline mtxgox & Texas Pocket Gopher & Geomys personatus & Mammal & 180217 \\
\hline msegox & Southeastern Pocket Gopher & Geomys pinetis & Mammal & 180218 \\
\hline mspogx & Strecker’s Pocket Gopher & Geomys streckeri & Mammal & 900166 \\
\hline mctpgx & Central Texas Pocket Gopher & Geomys texensis & Mammal & 552519 \\
\hline mnfsqx & Northern Flying Squirrel & Glaucomys sabrinus & Mammal & 180169 \\
\hline msfsqx & Southern Flying Squirrel & Glaucomys volans & Mammal & 180170 \\
\hline mwolvx & Wolverine & Gulo gulo & Mammal & 180551 \\
\hline mhitax & Himalayan Tahr & Hemitragus jemlahicus & Mammal & 625146 \\
\hline mabebx & Allen’s Big-eared Bat & Idionycteris phyllotis & Mammal & 180012 \\
\hline mshbax & Silver-haired Bat & Lasionycteris noctivagans & Mammal & 180014 \\
\hline mwrbax & Western Red Bat & Lasiurus blossevillii & Mammal & 552512 \\
\hline merbax & Eastern Red Bat & Lasiurus borealis & Mammal & 180016 \\
\hline mhobax & Hoary Bat & Lasiurus cinereus & Mammal & 180017 \\
\hline
\end{tabular}


Table 1.1. List of 1,590 species for which Gap Analysis Project (GAP) habitat distribution models were created and combined to generate maps of species richness maps by class (amphibia, bird, mammal, reptile). Species listed alphabetically by taxa and scientific name.-Continued

[ITIS, Integrated Taxonomic Information System; TSN, taxonomic serial number]

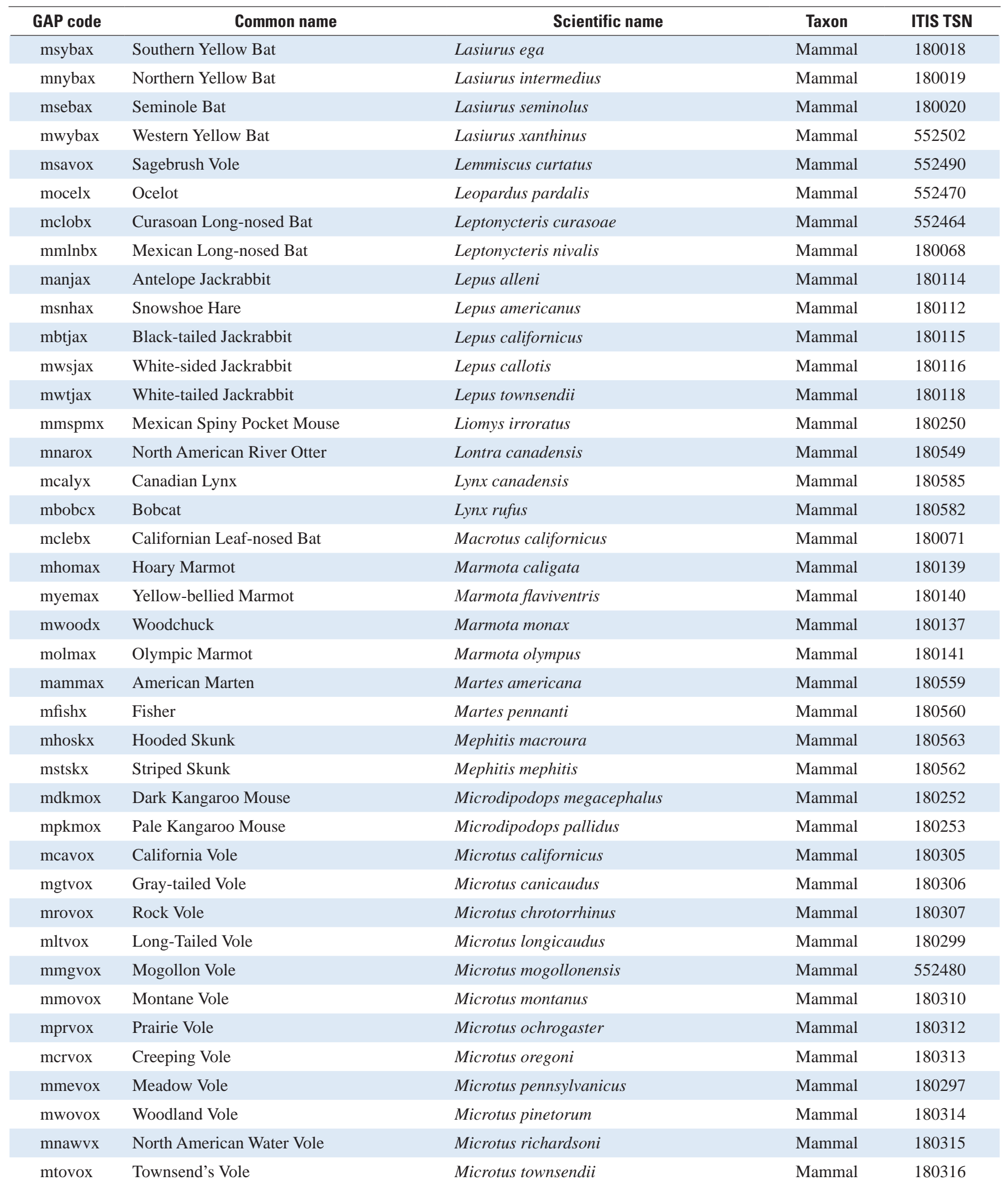


Table 1.1. List of 1,590 species for which Gap Analysis Project (GAP) habitat distribution models were created and combined to generate maps of species richness maps by class (amphibia, bird, mammal, reptile). Species listed alphabetically by taxa and scientific name.-Continued

[ITIS, Integrated Taxonomic Information System; TSN, taxonomic serial number]

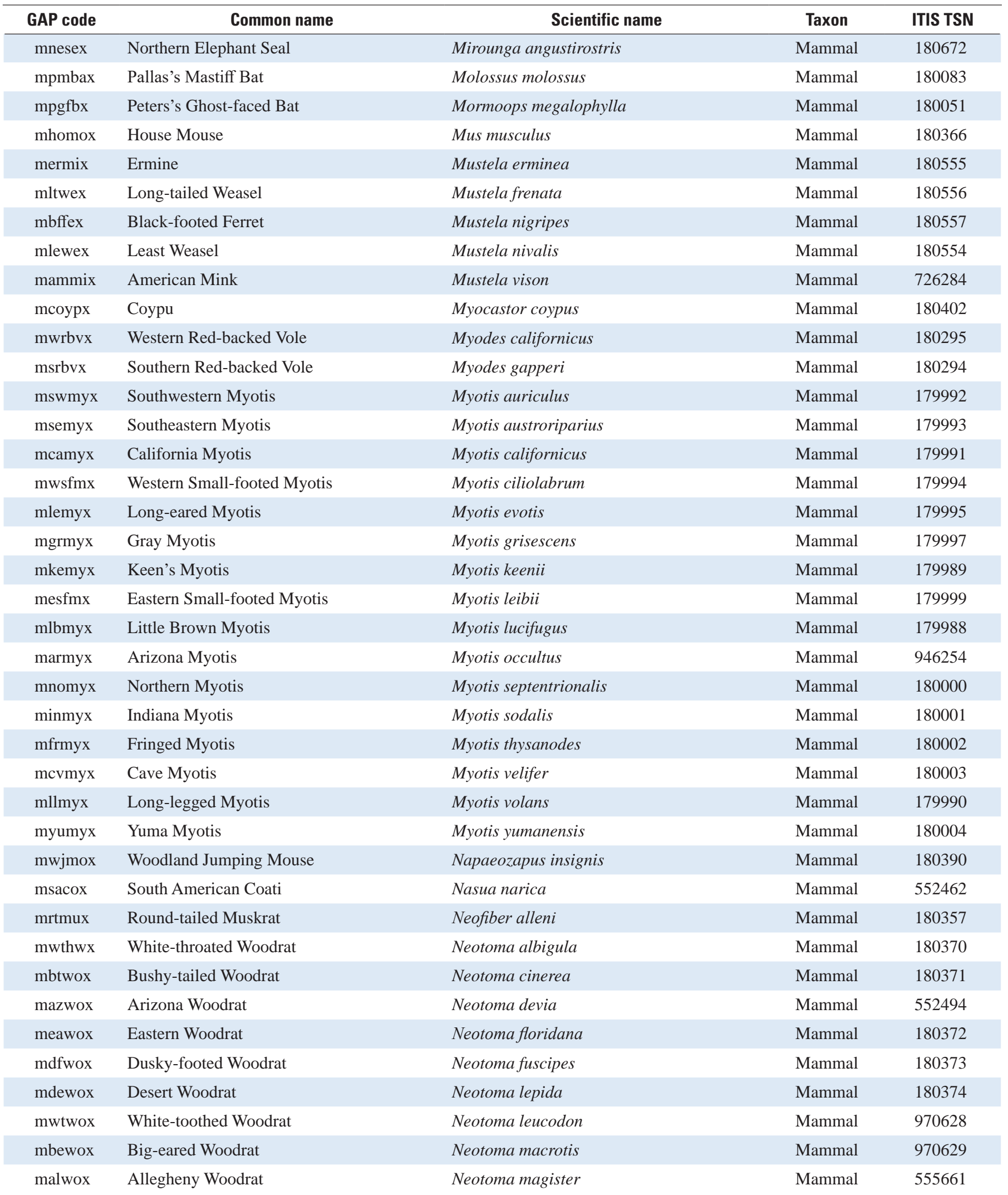


Table 1.1. List of 1,590 species for which Gap Analysis Project (GAP) habitat distribution models were created and combined to generate maps of species richness maps by class (amphibia, bird, mammal, reptile). Species listed alphabetically by taxa and scientific name.-Continued

[ITIS, Integrated Taxonomic Information System; TSN, taxonomic serial number]

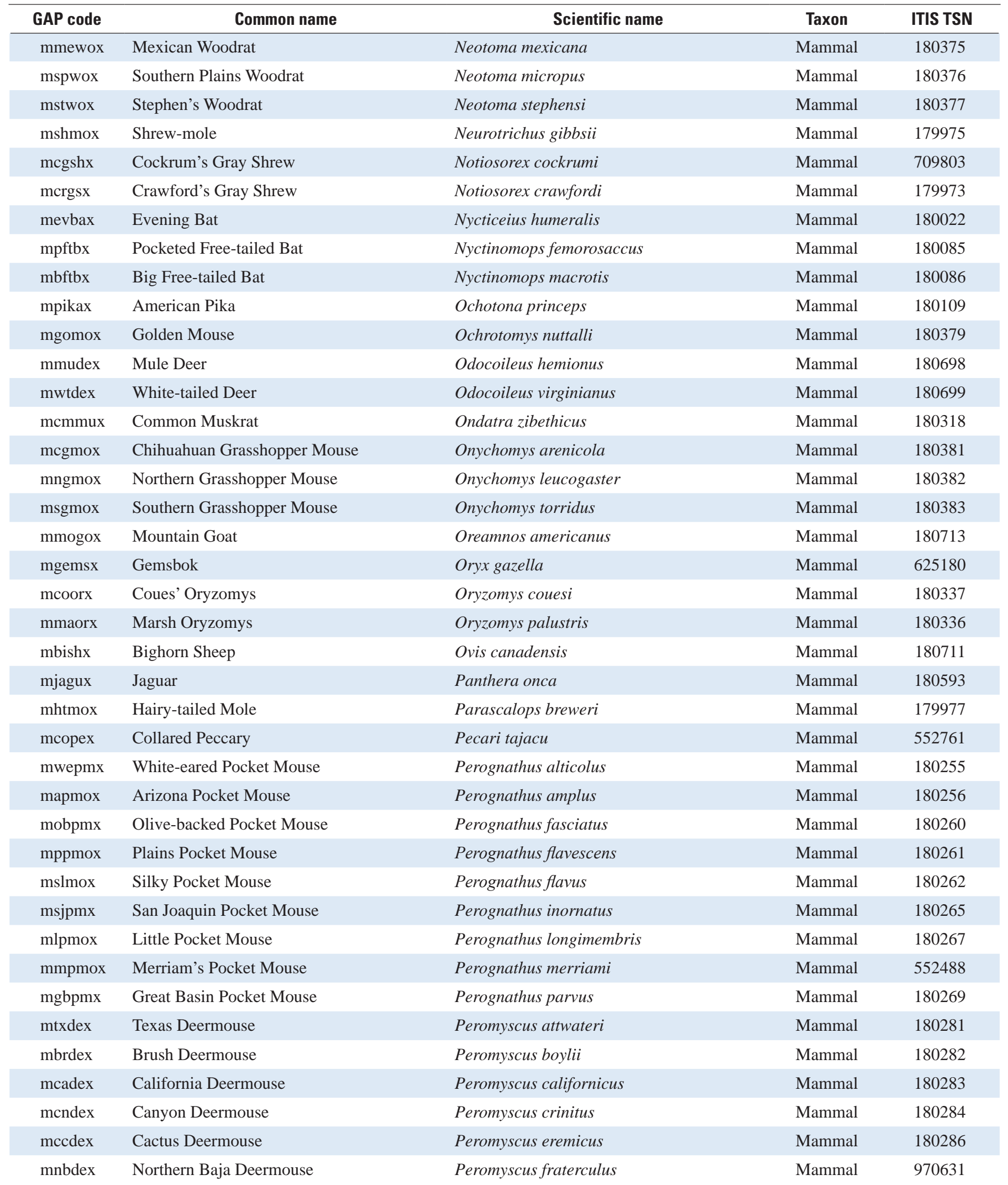


Table 1.1. List of 1,590 species for which Gap Analysis Project (GAP) habitat distribution models were created and combined to generate maps of species richness maps by class (amphibia, bird, mammal, reptile). Species listed alphabetically by taxa and scientific name.-Continued

[ITIS, Integrated Taxonomic Information System; TSN, taxonomic serial number]

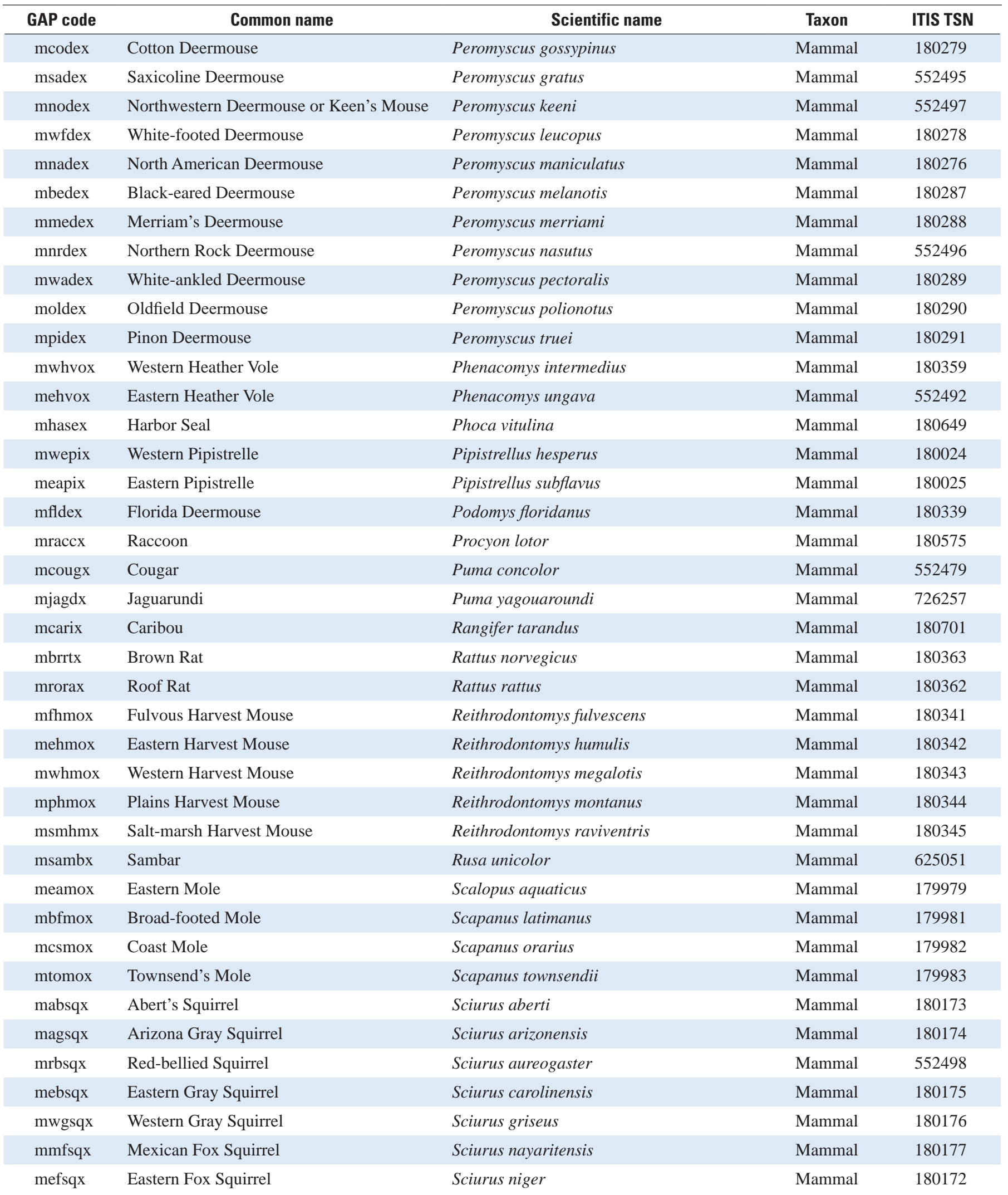


Table 1.1. List of 1,590 species for which Gap Analysis Project (GAP) habitat distribution models were created and combined to generate maps of species richness maps by class (amphibia, bird, mammal, reptile). Species listed alphabetically by taxa and scientific name.-Continued

[ITIS, Integrated Taxonomic Information System; TSN, taxonomic serial number]

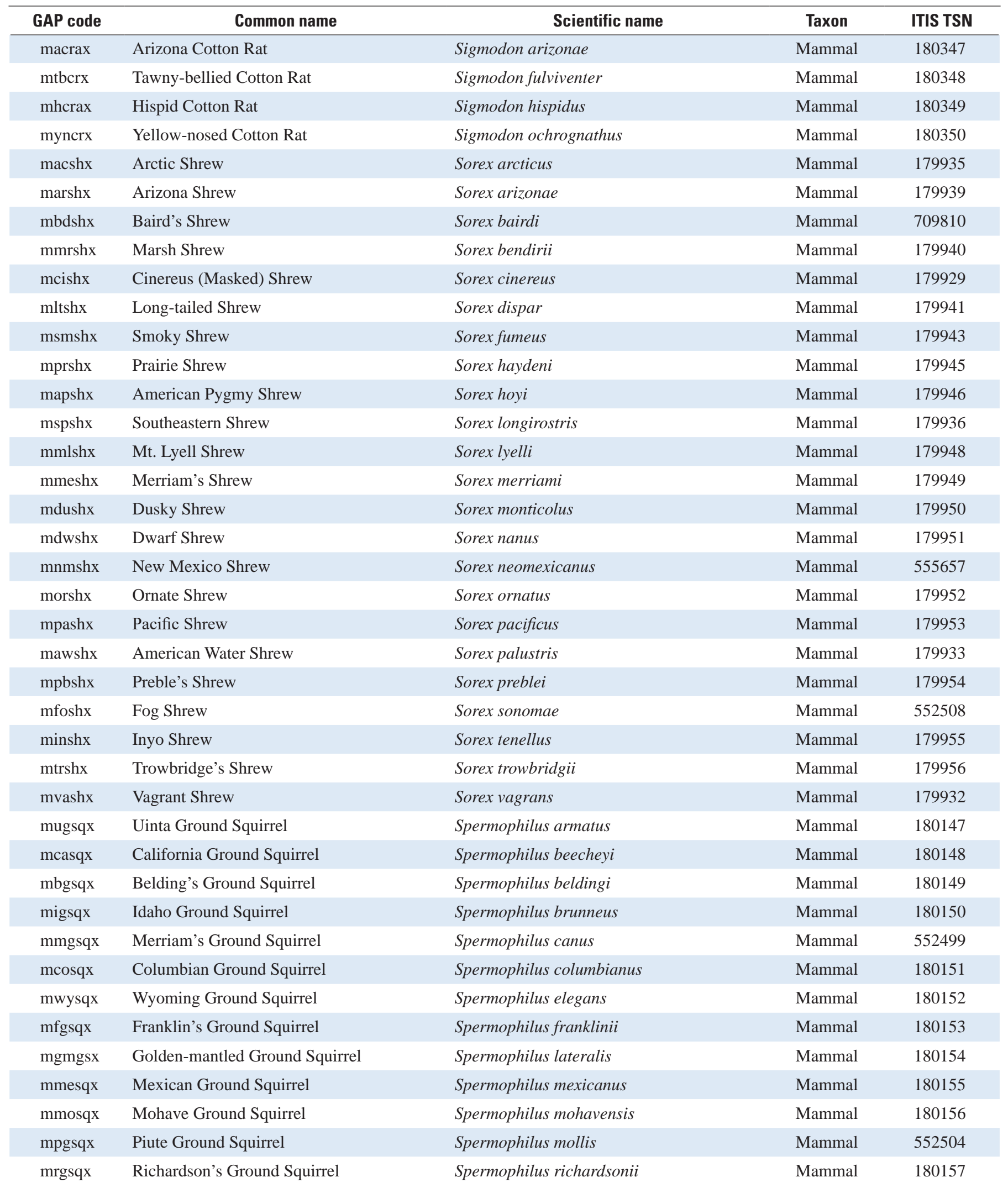


Table 1.1. List of 1,590 species for which Gap Analysis Project (GAP) habitat distribution models were created and combined to generate maps of species richness maps by class (amphibia, bird, mammal, reptile). Species listed alphabetically by taxa and scientific name.-Continued

[ITIS, Integrated Taxonomic Information System; TSN, taxonomic serial number]

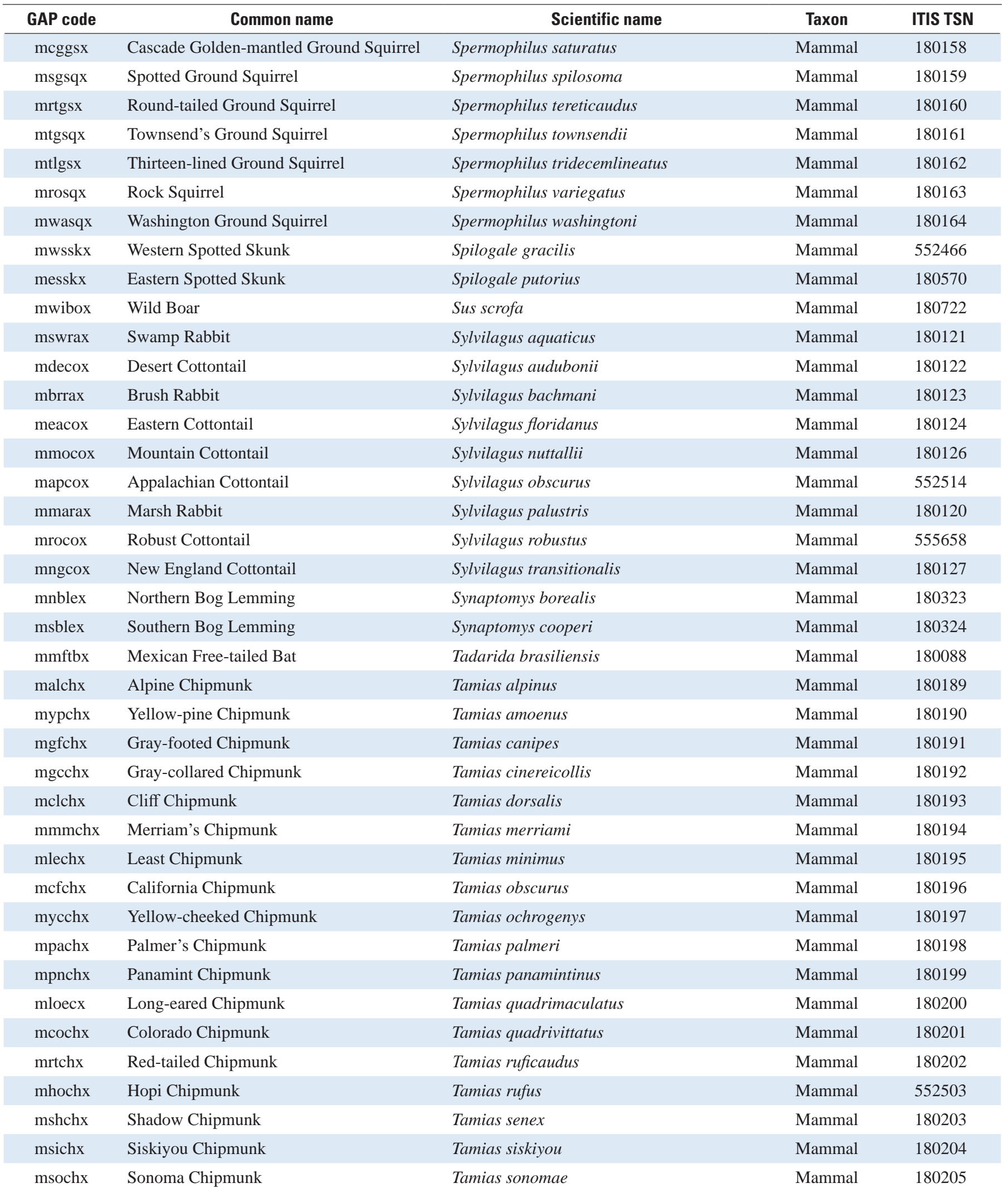


Table 1.1. List of 1,590 species for which Gap Analysis Project (GAP) habitat distribution models were created and combined to generate maps of species richness maps by class (amphibia, bird, mammal, reptile). Species listed alphabetically by taxa and scientific name.-Continued

[ITIS, Integrated Taxonomic Information System; TSN, taxonomic serial number]

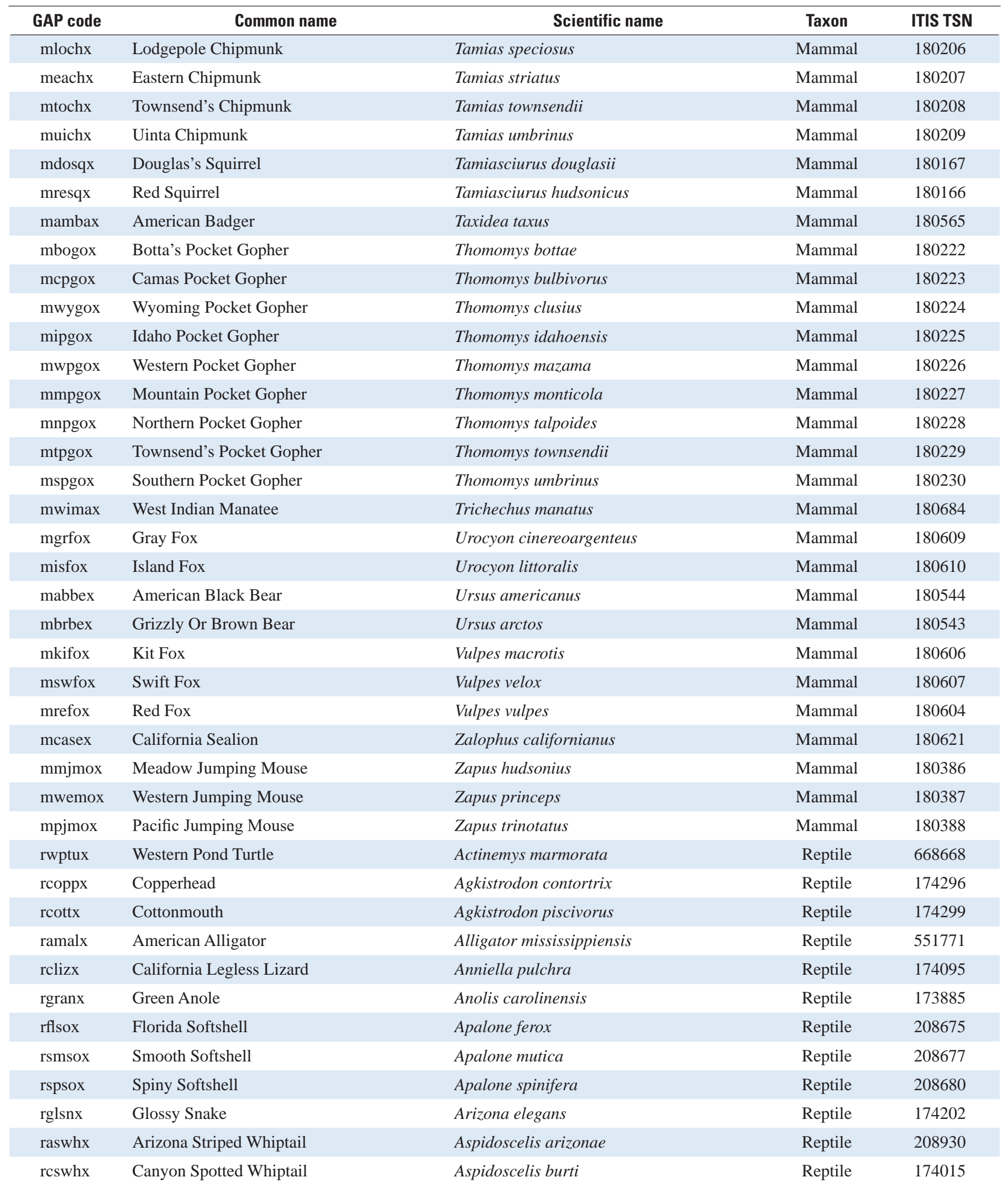


Table 1.1. List of 1,590 species for which Gap Analysis Project (GAP) habitat distribution models were created and combined to generate maps of species richness maps by class (amphibia, bird, mammal, reptile). Species listed alphabetically by taxa and scientific name.-Continued

[ITIS, Integrated Taxonomic Information System; TSN, taxonomic serial number]

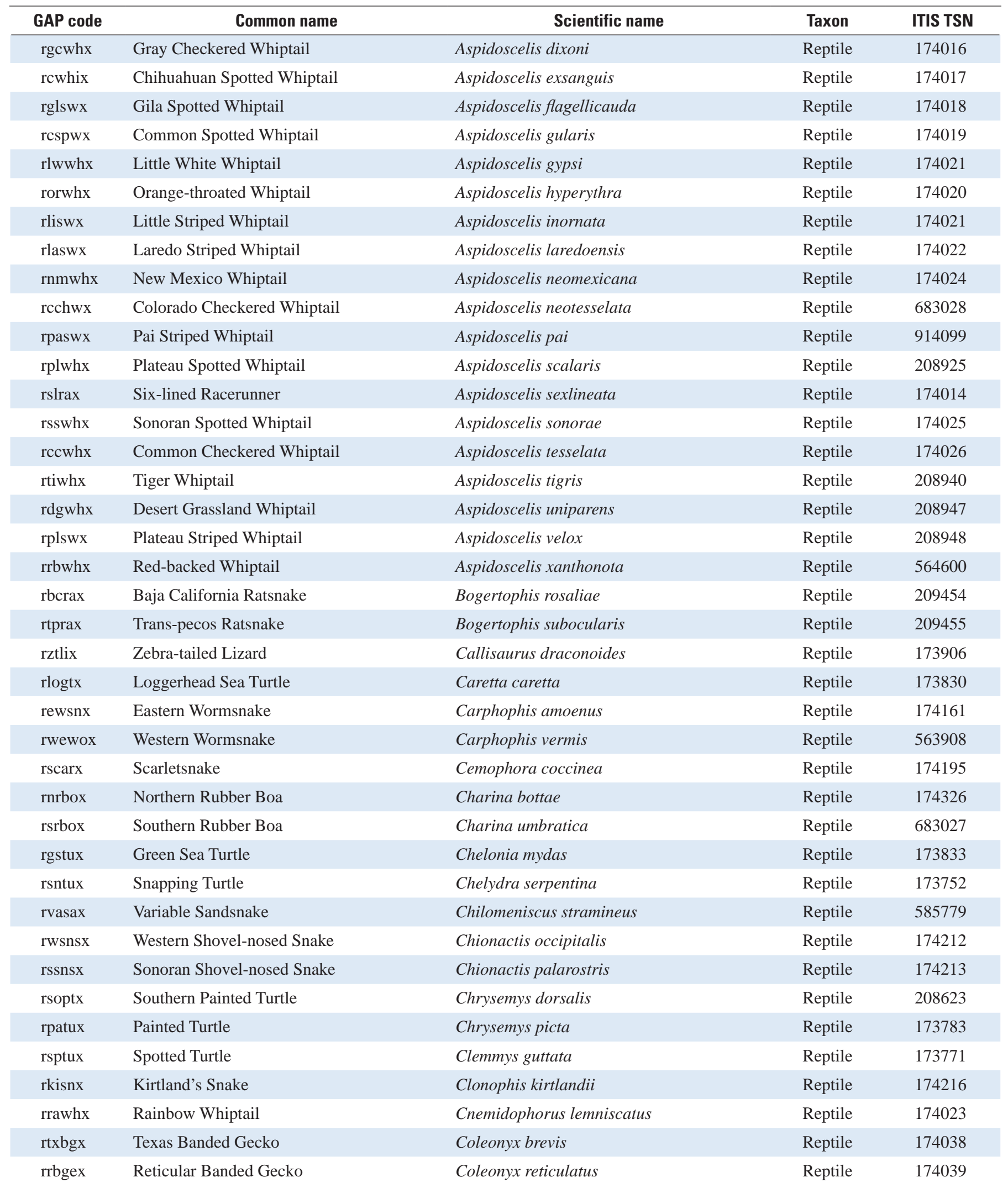


Table 1.1. List of 1,590 species for which Gap Analysis Project (GAP) habitat distribution models were created and combined to generate maps of species richness maps by class (amphibia, bird, mammal, reptile). Species listed alphabetically by taxa and scientific name.-Continued

[ITIS, Integrated Taxonomic Information System; TSN, taxonomic serial number]

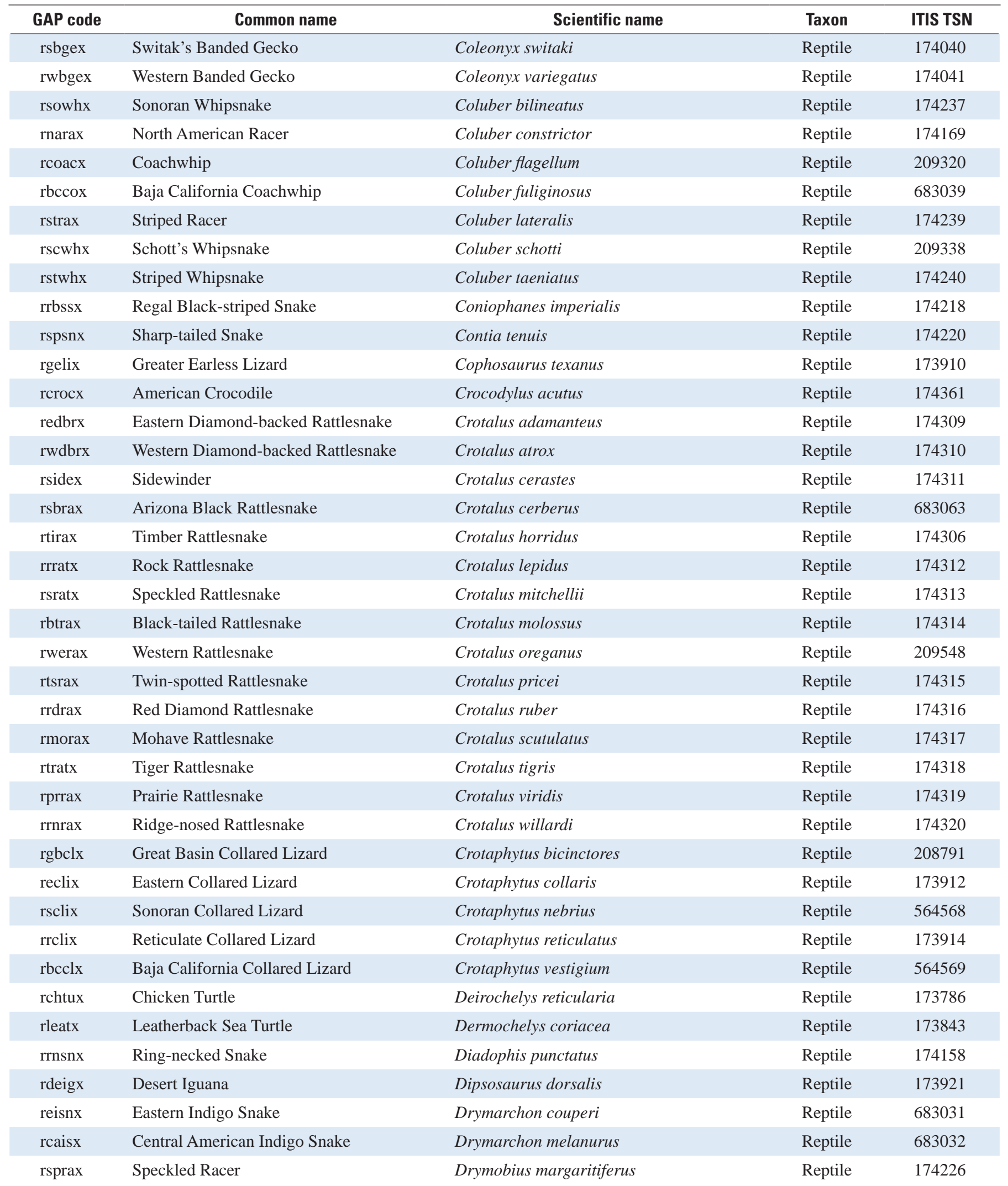


Table 1.1. List of 1,590 species for which Gap Analysis Project (GAP) habitat distribution models were created and combined to generate maps of species richness maps by class (amphibia, bird, mammal, reptile). Species listed alphabetically by taxa and scientific name.-Continued

[ITIS, Integrated Taxonomic Information System; TSN, taxonomic serial number]

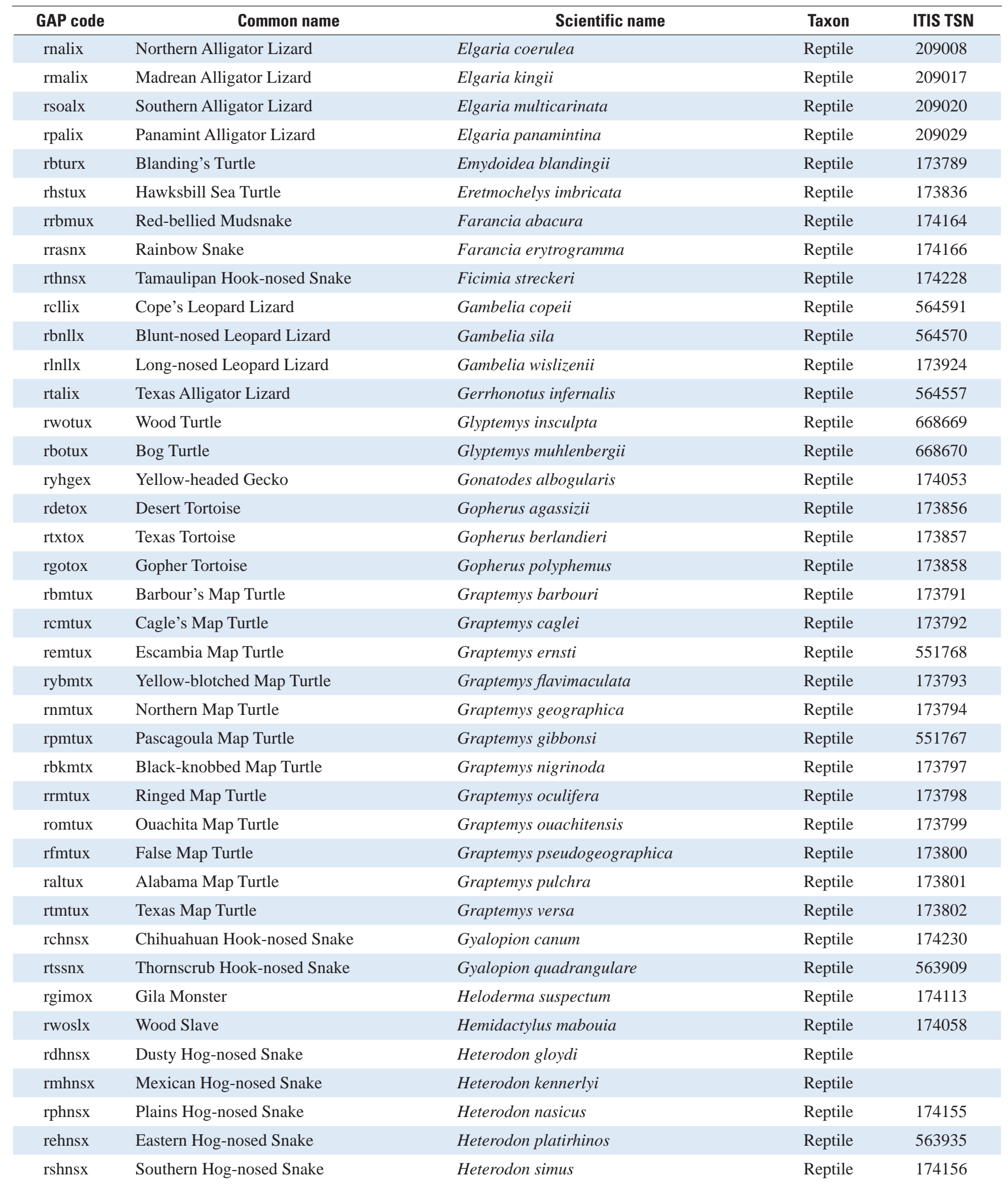


Table 1.1. List of 1,590 species for which Gap Analysis Project (GAP) habitat distribution models were created and combined to generate maps of species richness maps by class (amphibia, bird, mammal, reptile). Species listed alphabetically by taxa and scientific name.-Continued

[ITIS, Integrated Taxonomic Information System; TSN, taxonomic serial number]

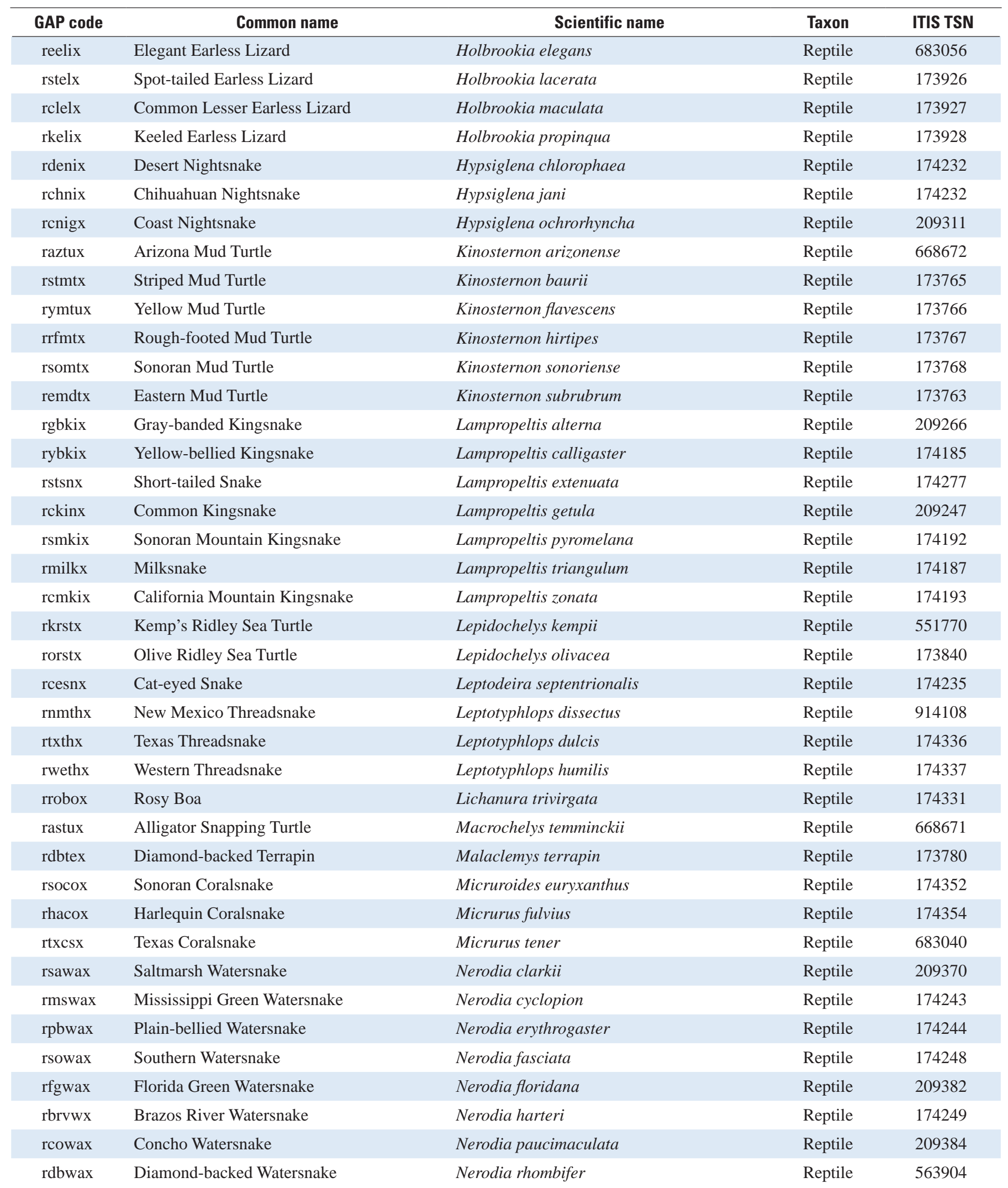


Table 1.1. List of 1,590 species for which Gap Analysis Project (GAP) habitat distribution models were created and combined to generate maps of species richness maps by class (amphibia, bird, mammal, reptile). Species listed alphabetically by taxa and scientific name.-Continued

[ITIS, Integrated Taxonomic Information System; TSN, taxonomic serial number]

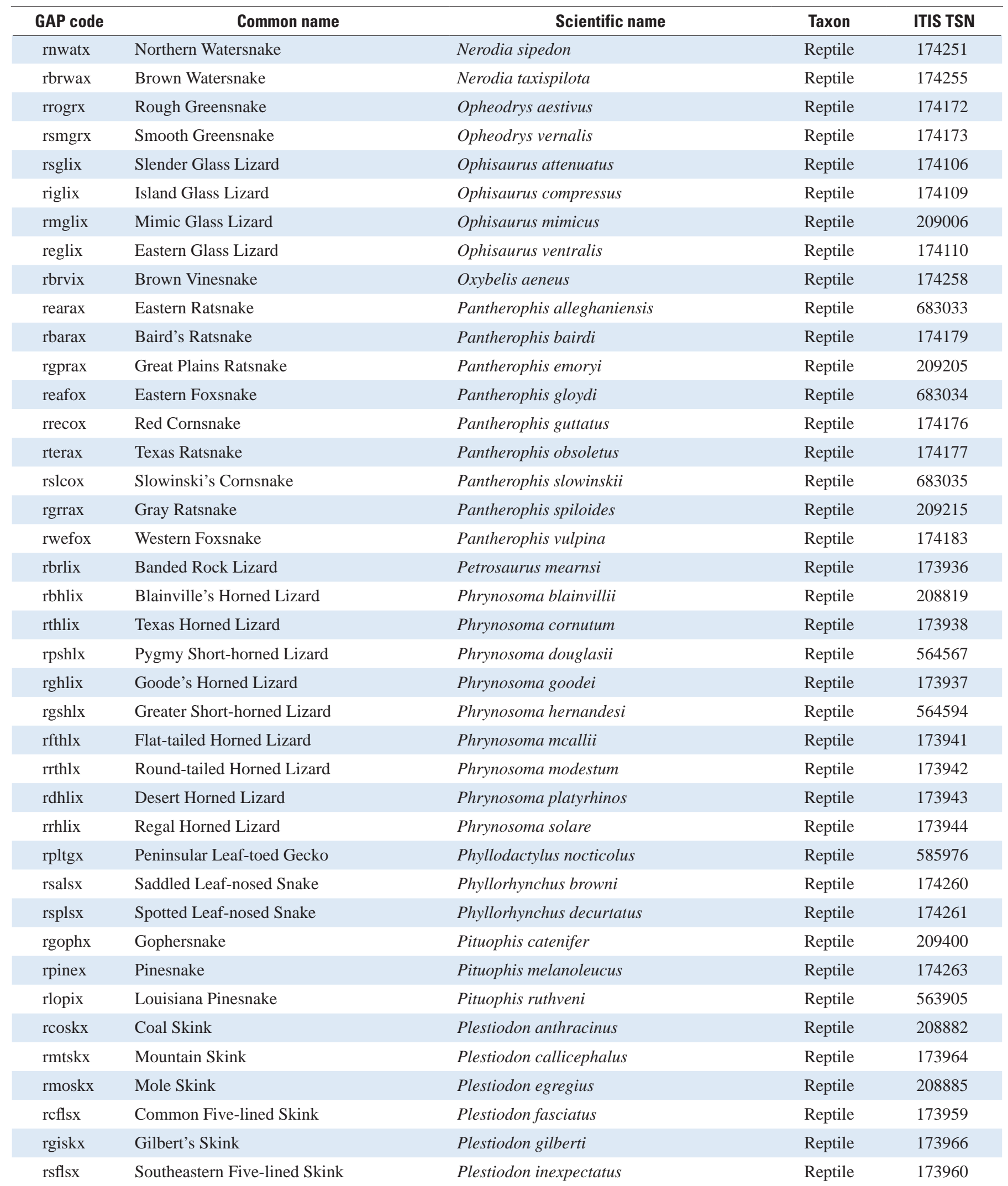


Table 1.1. List of 1,590 species for which Gap Analysis Project (GAP) habitat distribution models were created and combined to generate maps of species richness maps by class (amphibia, bird, mammal, reptile). Species listed alphabetically by taxa and scientific name.-Continued

[ITIS, Integrated Taxonomic Information System; TSN, taxonomic serial number]

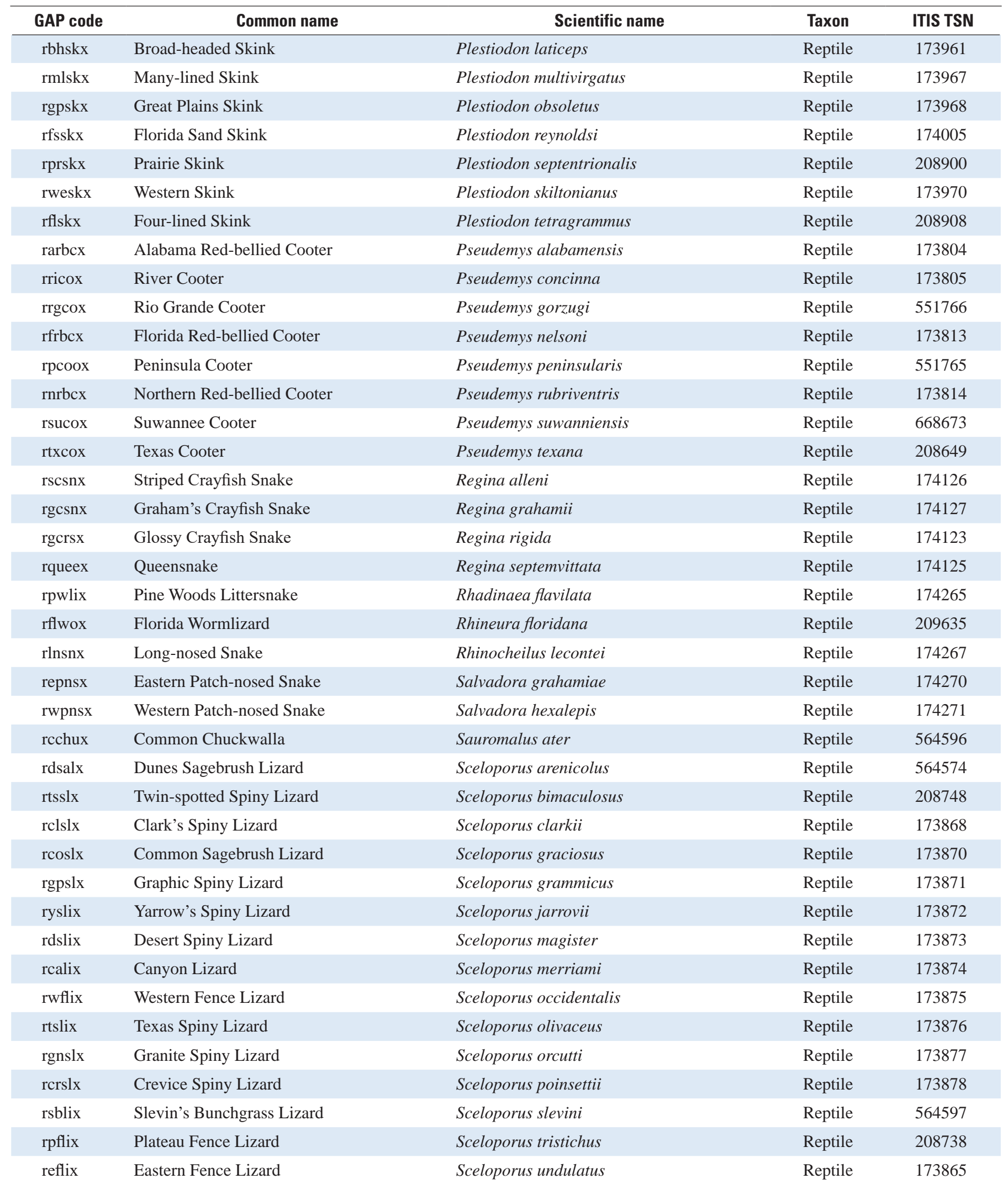


Table 1.1. List of 1,590 species for which Gap Analysis Project (GAP) habitat distribution models were created and combined to generate maps of species richness maps by class (amphibia, bird, mammal, reptile). Species listed alphabetically by taxa and scientific name.-Continued

[ITIS, Integrated Taxonomic Information System; TSN, taxonomic serial number]

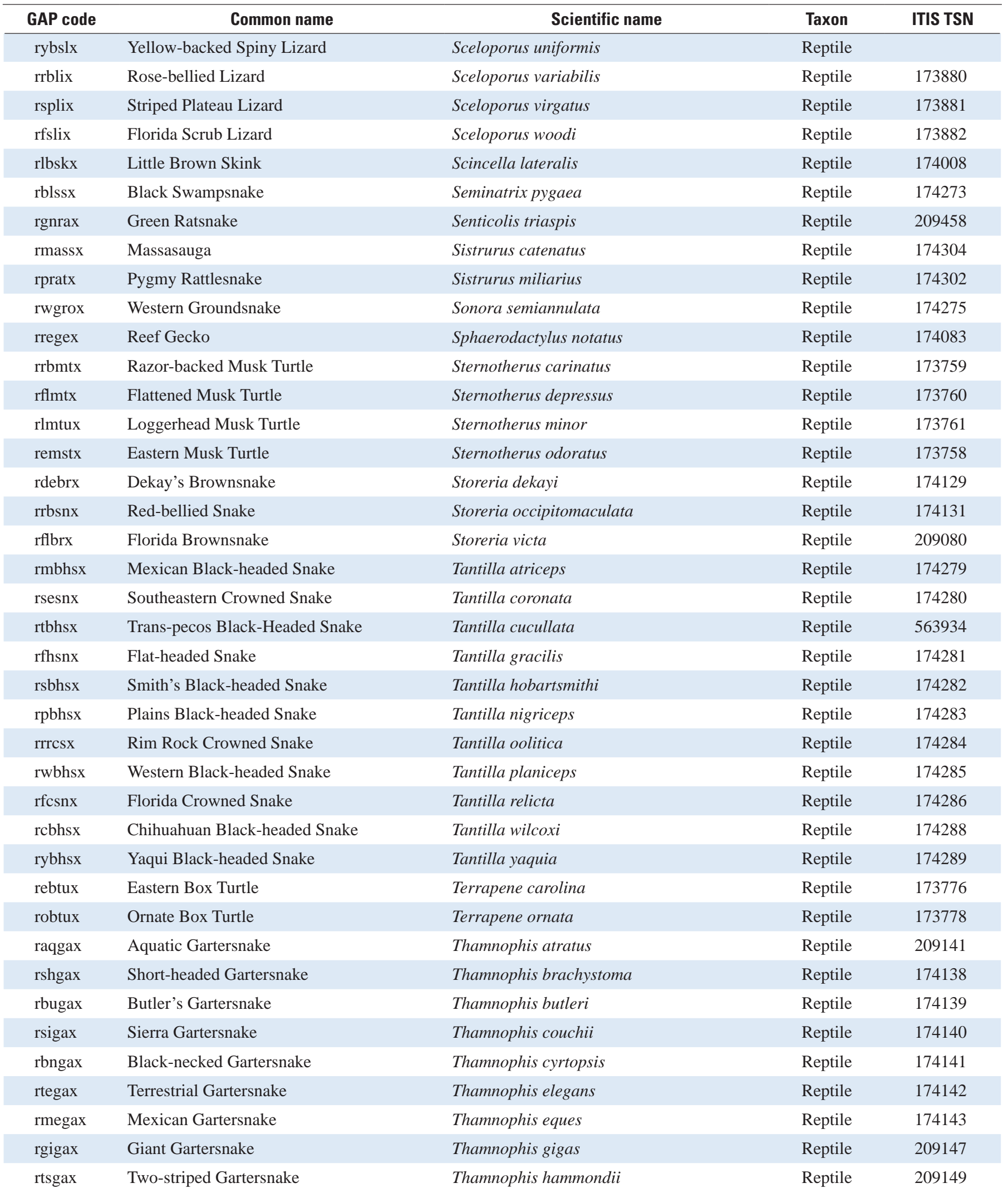


Table 1.1. List of 1,590 species for which Gap Analysis Project (GAP) habitat distribution models were created and combined to generate maps of species richness maps by class (amphibia, bird, mammal, reptile). Species listed alphabetically by taxa and scientific name.-Continued

[ITIS, Integrated Taxonomic Information System; TSN, taxonomic serial number]

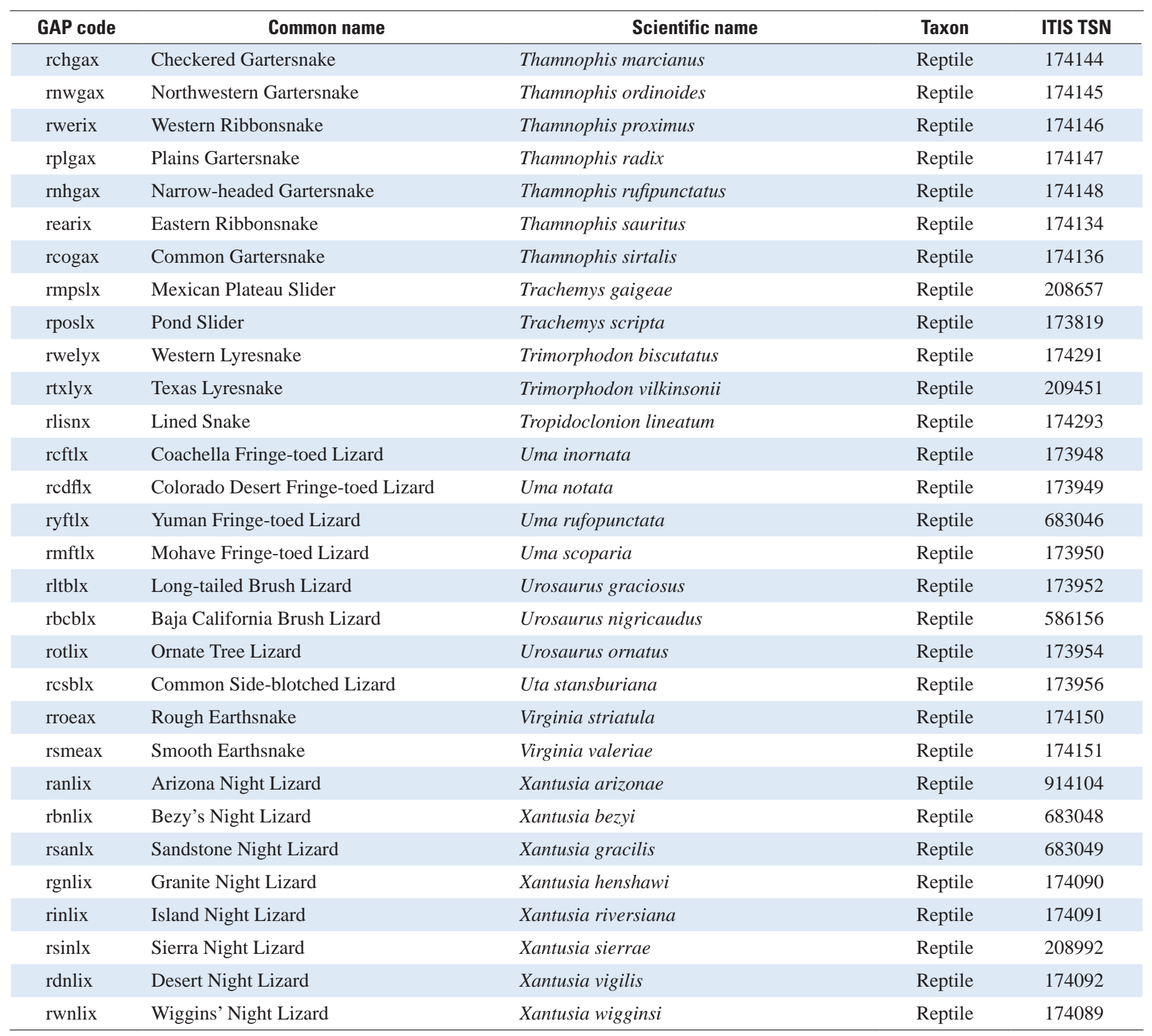




\section{Appendix 2. Selected References for Information Used to Delineate Species' Ranges}

These references constitute some of the most commonly used sources of species' range geography. It is not a complete list of all references used for each species. References without a specified date, especially those online, were accessed during the course of the Gap Analysis Project (GAP) which spanned approximately seven years (2011-2018).

\section{References}

Adams, R.A., 2003, Bats of the rocky mountain west-Natural history, ecology, and conservation: Boulder, University Press of Colorado, $302 \mathrm{p}$.

American Ornithologists' Union (AOU), 1983, Check-list of North American birds (6th ed.): Lawrence, Allen Press, Inc. 877 p.

American Ornithologists’ Union (AOU), ,1998, Check-list of North American birds (7th ed.): Washington, D.C., American Ornithologists., 829 p.

Ammerman, L.K., Hice, C.L., and Schmidly, D.J., 2012, Bats of Texas: College Station, Texas A \& M Press, 328 p.

Antonelis, G.A., Jr., and Fiscus, C.H., 1980, The pinnipeds of the California current: CalCOFI Report, v. XXI. [Also available at http://calcofi.org/ calcofi/publications/calcofireports/ v21/Vol 21 Antonelis Fiscus.pdf.]

Armstrong, D.M., Fitzgerald, J.P., and C.A. Meaney, 2011, Mammals of Colorado (2d ed.): Boulder, Colo., University Press of Colorado, $620 \mathrm{p}$.

Baker, R.J., Bradley, L.C., Bradley, R.D., Dragoo, J.W., Engstrom, M.D., Hoffman, R.S., Jones, C.A., Reid, F., Rice, D.W., and Jones, C., 2003, Revised checklist of North American mammals north of Mexico, 2003: Museum of Texas Tech University, Occasional Papers, no. 229, 23 p.

Banks, R.C., Chesser, R.T., Cicero, C., Dunn, J.L., Kratter, A.W., Lovette, I.J., Rasmussen, P.C., Remsen, J.V., Jr., Rising, J.D., Stotz, D.F., and Winker, K., 2008, Forty-ninth supplement to the American Ornithologists' Union checklist of North American Birds: The Auk, American Ornithologists' Union, v. 125, issue. 3, p. 758-768. [Also available at https://doi.org/10.1525/auk.2008.9708.]

Bartlett, R.D., and Tennant, A., 2000, Snakes of North America, Western Region: Houston, Gulf Publishing Company, $312 \mathrm{p}$.
Bat Conservation International, date variable, Species profiles: Austin, Bat Conservation International, Inc. [Also available at http://www.batcon.org/resources/media-education/ species-profiles.]

Beecham, J.J., Collins, C.P., and Reynolds, T.D., 2007, Rocky Mountain Bighorn Sheep (Ovis canadensis)—A technical conservation assessment: U.S. Department of Agriculture Forest Service, Rocky Mountain Region. [Also available at https://www.fs.usda.gov/Internet/FSE_DOCUMENTS/ stelprdb5181936.pdf.]

Brennan, T.C., and Holycross, A.T., 2009, A field guide to amphibians and reptiles in Arizona: Phoenix, Arizona Game and Fish Department. [Also available at https://www.azgfd. com/media/publications/.]

Bogan, M.A., and Cryan, P.M., 2000, Bats of Wyoming, in Choate, J.R., ed., Reflections of a naturalist-Papers honoring Professor Eugene D. Fleharty: Fort Hayes, Fort Hays State University, Fort Hayes Study Studies 69, special issue 1, p. 71-94. [Also available at https://scholars.fhsu.edu/ fort hays_studies_series/69/.]

Brady, J.R., and Maehr, D.S., 1985, Distribution of black bears in Florida: Florida Field Naturalist v. 13, p. 1-7.

Burbrink, F.T., 2001, Systematics of the eastern ratsnake complex (Elaphe obsoleta): Herpetological Monographs, v. 15, p. 1-53. [Also available at https://www.jstor.org/ stable/1467037.]

Burbrink, F.T., 2002, Phylogeographic analysis of the cornsnake (Elaphe guttata) complex as inferred from maximum likelihood and Bayesian analyses: Molecular Phylogenetics and Evolution, v. 25, issue 3, p. 465-476. [Also available at https://doi.org/10.1016/S1055-7903(02)00306-8.]

California Department of Fish and Game, date variable, California wildlife habitat relationships (CWHR) system species distribution maps: Sacramento, California Department of Fish and Wildlife. [Also available at https://www. wildlife.ca.gov/data/cwhr.]

California Natural Diversity Database (CNDDB), dates variable, Rarefind 4 computer program, 2010: Sacramento, California Department of Fish and Game, Biogeographic Data Branch, accessed July 30, 2018, at https://www. wildlife.ca.gov/data/cnddb.] 
Caso, A., de Oliveira, T., and Carvajal, S.V., 2015, Herpailurus yagouaroundi: The International Union for Conservation of Nature (IUCN), Red List of Threatened Species 2015, e.T9948A50653167, accessed August 29, 2016 at http://dx.doi.org/10.2305/IUCN.UK.2015-2.RLTS. T9948A50653167.en.

Choate, J.R., Jones, J.K., Jr., and Jones, C., 1994, Handbook of mammals of the south-central states: Baton Rouge, Louisiana State University Press, 304 p.

Cline, G.R., and Tumlison, R., 2001, Distribution and relative abundance of the Oklahoma salamander (Eurycea tynerensis): Oklahoma Academy of Science v. 81, [Proceedings], p. 1-10. [Also available at http://ojs.library.okstate. edu/osu/index.php/OAS/article/viewFile/5711/5335.]

Cockrum, E.L., 1960, The recent mammals of Arizona-Their taxonomy and distribution: Tucson, The University of Arizona Press, 276 p.

Collins, J.T., and Taggart, T.W., 2002, Standard common and current scientific names for North American amphibians, turtles, reptiles, \& crocodilians (5th ed.): Lawrence, Kan., Publication of The Center for North American Herpetology, $44 \mathrm{p}$.

Conant, R., and Collins, J.T., 1998, A field guide to the reptiles and amphibians_-Eastern and central North America: Boston, Houghton Mifflin, 616 p.

Crother, B.I., ed., 2008, Scientific and Standard English names of amphibians and reptiles of North America north of Mexico, with comments regarding confidence in our understanding (6th ed.): Society for the Study of Amphibians and Reptiles Herpetological Circular v. 37, p. 1-94.

Crother, B.I., ed., 2012, Standard common and current scientific names for North American amphibians, turtles, reptiles, and crocodilians (7th ed.): Herpetological Circular 39, p. 1-92. [Also available at http://www.southeastern.edu/ acad_research/depts/biol/faculty/pdf/crother2012.pdf.]

Crother, B.I., Boundy, J., Campbell, J.A., de Queiroz, K., Frost, D.R., Highton, R., Iverson, J.B., Meylan, P.A., Reeder, T.W., Seidel, M.E., Sites, J.W., Jr., Taggart, T.W., Tilley, S.G., and Wake, D.B., 2000, Scientific and standard English names of amphibians and reptiles of North America north of Mexico, with comments regarding confidence in our understanding: Society for the Study of Amphibians and Reptiles, Herpetological Circular no. 29, 82 p. [Also available at http://www.southeastern.edu/acad_research/depts/ biol/faculty/pdf/crother2001b.pdf.]
Crother, B.I., J. Boundy, J., Campbell, J.A., de Quieroz, K., Frost, D., Green, D.M., Highton, R., Iverson, J.B., McDiarmid, R.W., Meylan, P.A., Reeder, T.W., Seidel, M.E., Sites, J.W., Jr., Tilley, S.G., and Wake, D.B., 2003, Scientific and standard English names of amphibians and reptiles of North America north of Mexico, update: Herpetological Review no. 34, p. 198-203. [Also available at https://repository.si.edu/bitstream/handle/10088/4503/ VZ_2003crotheretal.pdf.]

Cryan, P.M., 2003, Seasonal distribution of migratory tree bats (Lasiurus and Lasionycteris) in North America: Journal of Mammalogy, v. 84, p. 579-593. [Also available at https:// academic.oup.com/jmammal/article/84/2/579/2373512.]

Degenhardt, W., Painter, C., and Price., A., 1996, Amphibians and reptiles of New Mexico: Albuquerque, University of New Mexico Press, 429 p.

DeLong, R.L., and Melin, S.R., 2000, Thirty years of pinniped research at San Miguel Island, in Fifth California Islands symposium, Santa Barbara Museum of Natural History, Calif., March 29-April 1, 1999, Proceedings: Santa Barbara, Calif., U.S. Department of Interior, Mineral Management Service Pacific OCS Region: p. 401-406.

Dixon, J.R., 2000, Amphibians and reptiles of Texas (2d ed.): College Station, Texas A \& M University Press. 429 p.

Dixon, J.R., and Werler, J.E., 2000, Texas Snakes—A Field Guide: Austin, University of Texas Press. 384 p,

Dodd, C.K., 2013, Frogs of the United States and Canada: Baltimore, The Johns Hopkins University Press. 982 p.

eBird, date variable, eBird-An online database of bird distribution and abundance, ver. 2 [web application]: Ithaca, Cornell Lab of Ornithology. [Also available at http://www. ebird.org.]

Edwards, C.W., Fulhorst, C.F., and Bradley, R.D, 2001, Molecular phylogenetics of the Neotoma albigula species group-Further evidence of a paraphyletic assemblage: Journal of Mammology v. 82, p. 267-279.

[Also available at https://academic.oup.com/jmammal/ article/82/2/267/2372777.]

Elrod, D.A., Zimmerman, E.G., Sudman, P.D., and Heidt, G.A., 2000, A new subspecies of pocket gopher (genus Geomys) from the Ozark Mountains of Arkansas with comments on its historical biogeography: Journal of Mammalogy, v. 81, p. 852-864. [Also available at https://academic. oup.com/jmammal/article/81/3/852/2372966.]

Feldhamer, G.A., Thompson, B.C., and Chapman, J.A., eds., 2003, Wild mammals of North America-Biology, management, and conservation (2d ed.): Baltimore, The Johns Hopkins University Press, 1,225 p. 
Findley, J.S., Harris, A.H., Wilson, D.E., and Jones, C., 1975, Mammals of New Mexico: Albuquerque, University of New Mexico, 360 ps.

Findley, J.S., 1987, The natural history of New Mexican mammals: Albuquerque, The University of New Mexico Press, $164 \mathrm{p}$.

Fitzgerald, J.P., Meaney, C.A. and Armstrong, D.M., 1994, Mammals of Colorado: Niwot, Denver Museum of Natural History and University Press of Colorado, 467 p.

Florida Fish and Wildlife Conservation Commission, 2012, Florida black bear management plan Ursus americanus floridanus: Tallahassee, Florida Fish and Wildlife Conservation Commission, Florida, 215 p. [Also available at https:// myfwc.com/media/1918/bear-management-plan.pdf.]

Florida Fish and Wildlife Conservation Commission, 2013, Florida panther (Puma concolor coryi) telemetry locations, February 1981-June 2013: Florida Fish and Wildlife Conservation Commission, accessed March 2014 at http://www. floridapanthernet.org/.

Florida Natural Areas Inventory (FNAI), 2010, Guide to the natural communities of Florida, 2010 ed.: Tallahassee, Florida Natural Areas Inventory. [Also available at https:// www.fnai.org/naturalcommguide.cfm.]

Frey, J. K., 2004, Taxonomy and distribution of the mammals of New Mexico-An annotated checklist occasional papers: Lubbock, Museum of Texas Tech University, no. 240, p. 1-32.

Ganey, J.L.; Ward, J.P., Jr.; Willey, D.W., 2011, Status and ecology of Mexican spotted owls in the Upper Gila Mountains recovery unit, Arizona and New Mexico: U.S. Department of Agriculture Forest Service, Rocky Mountain Research Station, General Technical Report RMRS-GTR256WWW, 94 p. [Also available at https://www.fs.usda. gov/treesearch/pubs/37799.]

Global Biodiversity Information Facility (GBIF), date variable, GBIF biodiversity data (database): Copenhagen, Global Biodiversity Information Facility. [Also available at: https://www.gbif.org/occurrence/search.]

Green, D.M., Weir, L.A., Casper, G.S., and Lannoo, M.J., 2014, North American amphibians_-Distribution and diversity: Berkeley, University of California Press. Berkeley, $340 \mathrm{p}$.

Hafner, D.J., Yensen, E., and Kirkland, G.L., Jr., compilers and eds., 1998, North American rodents-Status survey and conservation action plan: Gland, Switzerland, and Cambridge, U.K., IUCN/SSC Rodent Specialist Group, 171 p.

Hall, E.R., 1995, Mammals of Nevada: Las Vegas, University of Nevada Press, 710 p.
Hamel, P.B., 1992, The land manager's guide to the birds of the south: Chapel Hill, The Nature Conservancy, 367 p., and appendices.

Hammerson, G., 1999, Amphibians and reptiles in Colorado (2d ed.): Niwot, University Press of Colorado and Colorado Division of Wildlife, 484 p.

Helgen, K.M., Cole, F.R., Helgen, L.E., and Wilson, D.E., 2009, Generic revision in the holarctic ground squirrel genus Spermophilus: Journal of Mammalogy, v. 90, issue 2, p. 270-305. [Also available at https://doi.org/10.1644/07MAMM-A-309.1.]

Hendricks, S.A., Sesink Clee, P.R., Harrigan, R.J., Pollinger, J.P., Freedman, A.H., Callas, R., Figura, P.J., and Wayne, R.K., 2016, Re-defining historical geographic range in species with sparse records-Implications for the Mexican wolf reintroduction program: Biological Conservation, v. 194, p. 48-57, accessed July 30, 2018 at https://doi. org/10.1016/j.biocon.2015.11.027.

Highton, R., 1997, Geographic protein variation and speciation in the Plethodon dorsalis complex: Herpetologica, v. 53, p. 345-356. [Also available at https://www.jstor.org/ stable/3893344.]

Highton, R., 1999a, Geographic protein variation and speciation in the salamanders of the Plethodon cinereus group with the description of two new species: Herpetologica, v. 55, p. 43-90. [Also available at https://www.jstor.org/ stable/3893067.]

Highton, R., 1999b, Hybridization in the contact zone between Plethodon richmondi and Plethodon electromorphus in northern Kentucky: Herpetologica, v. 55, p. 91-105. [Also available at https://www.jstor.org/stable/3893068.]

Highton, R., 2004, A new species of woodland salamander of the Plethodon cinereus group from the Blue Ridge Mountains of Virginia: Virginia Museum of Natural History, Jeffersoniana, v. 14, p. 1-22. [Also available at https://www. vmnh.net/content/uploads/PDF/Research_and_Collections/ Jeffersoniana_Number_14.pdf.]

Highton, R., and Peabody, R.B., 2000, Geographic protein variation and speciation in salamanders of the Plethodon jordani and Plethodon glutinosus complexes in the Southern Appalachian Mountains with the description of four new species, in Bruce, R.C., Jaeger, R.G., and Houck, L.D., eds., The biology of Plethodontid salamanders: New York, Kluwer Academic, p. 31-93.

Hoffmeister, D.F., 1989, Mammals of Illinois: Urbana and Chicago, Museum of Natural History, University of Illinois Press. 349 p. 
Hoffmeister, D.F., 1970, The seasonal distribution of bats in Arizona-A case for improving mammalian range maps: The Southwestern Naturalist, v. 15, p. 11-22. [Also available at https://www.jstor.org/stable/3670197.]

Hoffmeister, D.F., 1986, Mammals of Arizona: Tucson, University of Arizona Press and the Arizona Game and Fish Department, 602 p. [Also available at https://www.jstor.org/ stable/3670197.]

Hulse, A.C., McCoy, C.J., and Censky, E.J., 2001, Amphibians and reptiles of Pennsylvania and the northeast: Ithaca, Cornell University Press. 419 p.

The International Union for the Conservation of Nature (IUCN), date variable, The International Union for the Conservation of Nature's (ICUN) red list of threatened species: Cambridge, U.K., The International Union for the Conservation of Nature. [Also available at https://www.iucnredlist. $\operatorname{org} /$.

Irschick, D.J., and Shaffer, H. B., 1997, The polytypic species revisited-Morphological differentiation among tiger salamanders (Ambystoma tigrinum) (Amphibia-Caudata): Herpetologica, v. 53, p. 30-49. [Also available at https:// www.jstor.org/stable/3893241.]

Jeffries, S.J., Gearin, P.J., Huber, H.R., Saul, D.L., and Pruett, D.A., 2000, Atlas of seal and sea lion haulout sites in Washington: Olympia, Washington Department of Fish and Wildlife, Wildlife Science Division, 150 p. [Also available at https://wdfw.wa.gov/publications/00427/.]

Jensen, J.B., Camp, C.D., Gibbons, W., and Elliot, M.J., eds., 2008, Amphibians and reptiles of Georgia: Athens, University of Georgia Press, 575 p.

Jockusch, E.L., Martinez-Solano, I., Hansen, R.W., and Wake, D.B., 2012, Morphological and molecular diversification of slender salamanders (Caudata - PlethodontidaeBatrachoseps) in the southern Sierra Nevada of California with descriptions of two new species: Zootaxa, 3190, p. 1-30, accessed July 30, 2018, at http://www.mapress. com/zootaxa/2012/2/zt03190p030.pdf.

Jones, J.K., Jr., and Birney, E.C., 1988, Handbook of mammals of the north-central states: Minneapolis, University of Minnesota Press, 346 p.

Keinath, D.A., Griscomm, H.R., and Andersen, M.D., 2014, Habitat and distribution of the Wyoming pocket gopher (Thomomys clusius): Journal of Mammalogy v. 95, issue 4, p. 803-813, accessed July 30, 2018, at https://doi. org/10.1644/13-MAMM-A-226.

Lannoo, M., ed., 2005, Amphibian Declines-The conservation status of United States species: Berkeley, University of California Press, p. 1094.
Leache, A.D., and Mulcahy, D.G., 2007, Phylogeny, divergence times and species limits of spiny lizards (Sceloporus magister species group) in western North American deserts and Baja California: Molecular Ecology, v. 16, issue 24, p. 5216-5233. [Also available at https://doi.org/10.1111/ j.1365-294X.2007.03556.x.]

Leavitt, D.H., Bezy, R.L., Crandall, K.A., and Sites, J.W., Jr., 2007, Multi-locus DNA sequence data reveal a history of deep cryptic vicariance and habitat-driven convergence in the desert night lizard Xantusia vigilis species complex (Squamata: Xantusiidae): Molecular Ecology, v. 16, issue 21, p. 4455-4481. [Also available at https://doi. org/10.1111/j.1365-294X.2007.03496.x.]

Linzey, D.W., 1979a, The snakes of Alabama: Huntsville, Strode Publishers, 136 p.

Linzey, D.W., ed., 1979b, Endangered and threatened plants and animals of Virginia: Blackburg, Virginia Polytechnic Institute and State University, 665 p.

Linzey, D.W., 1995, Mammals of the Great Smoky Mountains National Park, 1995 update: Journal of the Elisha Mitchell Scientific Society, v. 111, no. 1, p. 1-81. [Also available at https://www.jstor.org/stable/24335128.]

Linzey, A.V., and Linzey, D.W., 1971, Mammals of the Great Smoky Mountains National Park: Knoxville, The University of Tennessee Press, 114 p.

Loeb, S.C.; Lacki, M.J.; Miller, D.A., eds., 2011, Conservation and management of eastern big-eared bats-A symposium, Asheville, N.C.: U.S. Department of Agriculture, Forest Service, Southern Research Station, General Technical Report SRS-145, 157 p. [Also available at https://www. fs.usda.gov/treesearch/pubs/39814.]

Long, C.A., 2008, The wild mammals of Wisconsin: Sofia, Bulgaria, Pensoft Publishers, Series Faunistica no. 68, $545 \mathrm{p}$. [Also published as University of Wisconsin Museum of Natural History, Reports on the Fauna and Flora of Wisconsin, publication no. 56.]

Marks, C.S., and Marks, G.E., 2006, Bats of Florida: Gainesville, University of Florida Press, 176 p.

Marshall, D.B., Hunter, M.G., and Contreras, A.L., eds., 2003, Birds of Oregon - A general reference: Corvallis, Oregon State University Press, 768 p.

Martof, B.S., Palmer, W.M., Bailey, J.R., and Harrison, J.R., III., 1980, Amphibians and reptiles of the Carolinas and Virginia: Chapel Hill, University of North Carolina Press, $264 \mathrm{p}$. 
McKnight, M.L., 2005, Phylogeny of the Perognathus longimembris species group based on mitochondrial cytochrome-b- How many species?: Journal of Mammalogy, v. 86, p. 826-832. [Also available at https://doi. org/10.1644\%2F1545-1542(2005)086\%5B0826\%3APOTP LS\%5D2.0.CO\%3B2.]

Merritt, J.F., 1987, Guide to the mammals of Pennsylvania; Pittsburgh, University of Pittsburgh Press, 408 p.

Mulcahy, D.G., 2008, Phylogeography and species boundaries of the western North American Nightsnake (Hypsiglena torquata)—Revisiting the subspecies concept: Molecular Phylogenetics and Evolution, v. 46, p. 1095-1115. [Also available at https://doi.org/10.1016/j.ympev.2007.12.012.]

Muller, J.W., Hardin, E.D., Jackson, D.R., Gatewood, S.E., and Caire, N., 1989, Summary report on the vascular plants, animals, and plant communities endemic to Florida: Florida Game and Freshwater Fish Commission Nongame Project Report GFC-84-0027, p. 1-113. [Also available at http:// f50006a.eos-intl.net/F50006A/OPAC/Details/Record. aspx?BibCode=623040.]

National Audubon Society, date variable, The Christmas bird count historical results: New York, National Audubon Society. [Also available at http://www.christmasbirdcount.org.]

NatureServe, date variable, NatureServe Explorer-An online encyclopedia of life: Arlington, NatureServe. [Also available at http://explorer.natureserve.org.]

North American Breeding Bird Atlas Committee, date variable, North American breeding bird atlases by state: North American Ornithological Atlas Committee (NORAC). [Published atlases available at http://www.bsc-eoc.org/norac/ index.jsp?targetpg=atlaslist1\&lang=EN.]

Oliver, G.V., 2000, Bats of Utah-A literature review: Salt Lake City, Utah Division of Wildlife Resources, Publication no. 00-14, 140 p. [Also available at https://dwrcdc.nr.utah. gov/ucdc/ViewReports/bats.pdf.]

Orabona A., Patla, S., Van Fleet, L., Grenier, M., Oakleaf, B., and Walker, Z., 2009, Atlas of birds, mammals, amphibians, and reptiles in Wyoming: Lander, Wyo., Game and Fish Department Nongame Program, 227 p.

Palmer, W.M., and Braswell, A.L., 1995, Reptiles of North Carolina: Chapel Hill, North Carolina State Museum of Natural Sciences, University of North Carolina Press, North Carolina, 448 p.

Paulson, D., 1993, Shorebirds of the Pacific Northwest: Seattle, University of Washington Press, 406 p.

Perry, N.D., 2006, Lower Keys marsh rabbit and silver rice rat-Steps towards recovery: College Station, Tex., Texas A\&M University, Master's thesis. [Also available at http:// hdl.handle.net/1969.1/4260.]
Petranka, J.W., 1998, Salamanders of the United States and Canada: Washington, D.C., Smithsonian Institute Press, $587 \mathrm{p}$.

Piaggio A.J., and Jeffers, J., 2013, On the edge-A genetic assessment of Aplodontia rufa from the edge of their distribution: Western North American Naturalist, v. 73, issue 4, p. 485-496, accessed July 30, 2018, at https://www.jstor. org/stable/24644080.

Piaggio, A.J., Navo, K.W., and Stihler, C.W., 2009, Intraspecific comparison of population structure, genetic diversity, and dispersal among three subspecies of Townsend's Big-eared Bats, Corynorhinus townsendii townsendii, C. $t$. pallescens, and the Endangered C. t. virginianus: Conservation Genetics, v. 10, issue 1, p. 143-159. [Also available at https://doi.org/10.1007/s10592-008-9542-0.]

Piaggio, A.J., and Perkins, S. L., 2005, Molecular phylogeny of North American long-eared bats (Vespertilionidae: Corynorhinus); inter- and intraspecific relationships inferred from mitochondrial and nuclear DNA sequences: Molecular Phylogenetics and Evolution, v. 37, issue 3, p. 762-775. [Also available at https://doi.org/10.1016/j. ympev.2005.03.029.]

Pierson, E.D., and Rainey, W.E., 1998, Distribution, status, and management of Townsend's Big-eared bat (Corynorhinus townsendii) in California: California Department of Fish and Game, BMCP Technical Report no. 96-7, 34 ps. [Also available at https://nrm.dfg.ca.gov/FileHandler. ashx?DocumentID=3038.]

Popper, K.J., and Stern, M.A., 2000, Nesting ecology of Yellow Rails in southcentral Oregon: Journal of Field Ornithology, v. 71, p. 460-466. [Also available at https://doi. org/10.1648/0273-8570-71.3.460.]

Reeder, T.W., Cole, C.J., and Dessauer, H.C., 2002, Phylogenetic relationships of whiptail lizards of the genus Cnemidophorus (Squamata: Teiidae) - A test of monophyly, reevaluation of karyotypic evolution, and review of hybrid origins: American Museum Novitates, v. 78, issue 3365, p. 1-61. [Also available at https://bioone.org/ journals/American-Museum-Novitates/volume-2002/ issue-3365/0003-0082(2002)365\%3C0001:PROWLO \%3E2.0.CO;2/Phylogenetic-Relationships-of-WhiptailLizards-of-the-Genus-span-classgenus/10.1206/00030082(2002)365\%3C0001:PROWLO\%3E2.0.CO;2.full.]

Riddle, B.R., Hafner, D.J., and Alexander, L. F., 2000, Comparative phylogeography of Bailey's pocket mouse (Chaetodipus baileyi) and the Peromyscus eremicus species group-historical vicariance of the Baja California peninsular desert: Molecular Phylogenetics and Evolution, v. 17, p. 161-172. [Also available at https://doi.org/10.1006/ mpev.2000.0842.] 
Riddle, B.R., Jezkova, T., Eckstut, M. E., Oláh-Hemmings, V., and Carraway, L.N., 2014, Cryptic divergence and revised species taxonomy within the Great Basin pocket mouse, Perognathus parvus (Peale, 1848), species group: Journal of Mammalogy, v. 95, p. 9-925, accessed July 30, 2018, at https://doi.org/10.1644/12-MAMM-A-252.

Schmidly, D.J., 1991, The bats of Texas: College Station, Texas A \& M University. Press, 188 p.

Schmidly, D.J., 2004, The mammals of Texas (revised ed.): Austin, University of Texas Press, 521 p.

Schmidly, D.J., and Hendricks, F.S., 1984, Mammals of the San Carlos Mountains of Tamaulipas, Mexico, in Martin, R.E., and Chapman, B.R., eds., Contributions in mammalogy in honor of Robert L. Packard: Lubbock, Special Publications, The Museum, Texas Tech University, p. 15-69.

Schmidt, C. J., Taggart, T.W., Kaufman, G.A., Kaufman, D.W., Finck, E.J., Hope, A., Peek, M., and Timm, R., 2018, Kansas mammal atlas-An on-line reference electronic database: Hays, Fort Hays State University, Sternberg Museum of Natural History, accessed July 30, 2018, at http://webapps.fhsu.edu/ksmammal/.]

Schwartz, C., and Schwartz, E., 2001, The wild mammals of Missouri (2d ed.): Columbia, University of Missouri Press and Missouri Department of Conservation, 368 p.

Sealander, J.A., 1979, A guide to Arkansas mammals: Conway, River Road Press, 313 p.

Sealander, J.A. and Heidt, G.A., 1990, Arkansas mammalsTheir history, classification, and distribution: Fayetteville, University of Arkansas Press, 308 p.

Shaffer, H.B., and McKnight, M.L., 1996, The polytypic species revisited-Genetic differentiation and molecular phylogenetics of the tiger salamander Ambystoma Tigrinum (Amphibia-Caudata) complex: Evolution, v. 50, p. 417-433. [Also available at https://doi. org/10.1111/j.1558-5646.1996.tb04503.x.]

Shaffer, H.B., Fellers, G.M., Voss, S.R., Oliver, J.C., and Pauly, G.B., 2004, Species boundaries, phylogeography and conservation genetics of the red-legged frog (Rana aurora/ draytonii) complex: Molecular Ecology, v. 13, p. 26672777. [Also available at https://doi.org/10.1111/j.1365294X.2004.02285.x.]

Sharpe R.S., Silcock, W.R., and Jorgensen, J.G., 2001, Birds of Nebraska-Their distribution and temporal occurrence: Lincoln and London, University of Nebraska Press, 521 p.
Shuford, W.D., and Gardali, T. eds., 2008, California bird species of special concern-A ranked assessment of species, subspecies, and distinct populations of birds of immediate conservation concern in California, Studies of western birds no. 1: Camarillo, Western Ornithologists, and California Department of Fish and Game, 450 p.

Sibley, D.A., 2000, The Sibley guide to birds: New York, Alfred A. Knopf, 544 p.

Smith, S.J., Leslie, D.M., Jr., Hamilton, M.J., Lack, J.B., and Van Den Bussche, R., 2008, Subspecific affinities and conservation genetics of western big-eared bats (Corynorhinus townsendii pallescens) at the edge of their distributional range: Journal of Mammalogy v. 89, issue 4, p.799-814. [Also available at https://doi.org/10.1644/06-MAMMA-279.1.]

Sinclair, E.A., Bezy, R.L., Bolles, K., Camarillo R, J.L., Crandall, K. A., and Sites, J.W., Jr. 2004, Testing species boundaries in an ancient species complex with deep phylogeographic history—genus Xantusia (Squamata: Xantusiidae): American Naturalist 164:396-414. [Also available at https://doi.org/10.1086/381404.]

Spaulding, A.W., Mock, K.E., Schroeders, M.A., Warheit, K.I., 2006, Recency, range expansion, and unsorted lineagesImplications for interpreting neutral genetic variation in the sharp-tailed grouse (Tympanuchus phasianellus): Molecular Ecology, v. 15, p. 2317-2332. [Also available at https://doi. org/10.1111/j.1365-294X.2006.02935.x.]

Sparks, D.W., and Choate, J.R., 2000, Distribution, natural history, conservation status, and biogeography of bats in Kansas, in Choate, J.R., ed., Reflections of a naturalist-Papers honoring Professor Eugene D. Fleharty: Fort Hays State University, Fort Hayes Study 69, special issue 1, p. 173-228. [Also available at https://scholars.fhsu.edu/ fort_hays_studies_series/69/.]

Stebbins, R.C., 1985, A field guide to western reptiles and amphibians ( $2 \mathrm{~d}$ ed.): Boston, Houghton Mifflin Company, Peterson Field Guide, xiv+336 p.

Stebbins, R.C., 2003, A field guide to western reptiles and amphibians ( $3 \mathrm{~d}$ ed.): Boston, Houghton Mifflin, Peterson Field Guide, 560 p.

Stern, M.A., Morawski, J.F., and Rosenberg, G.A., 1993, Rediscovery and status of a disjunct population of breeding yellow rails in southern Oregon: Condor, v. 95, p. 1024-1027. [Also available at https://www.jstor.org/ stable/1369438.] 
Sullivan, R.M., and Petersen, K.F., 1988, Systematics of southwestern populations of least chipmunks (Tamias minimus) reexamined-A synthetic approach: The Museum of Southwestern Biology, Occasional Papers, no. 5, p. 1-27. [Also available at https://digitalrepository.unm.edu/occasionalpapers/10/.]

Taulman, J.F., and Robbins, L.W., 2014, Range expansion and distributional limits of the nine-banded armadillo (Dasypus novemcinctus) in the United States-An update of Taulman \& Robbins (1996): Journal of Biogeography, v. 41, issue 8, p. 1626-1630, accessed July 30, 2018, at https:// doi.org/10.1111/j.1365-2699.1996.tb00024.x.

The American Society of Mammalogists, date variable, Mammalian species: The American Society of Mammalogists. [Updated spreadsheet available at http://www. mammalsociety.org/publications/mammalian-species.]

The Cornell Laboratory of Ornithology, dates variable, Birds of North America: Ithaca, Cornell Laboratory of Ornithology. [Online database available at https://birdsna.org.]

Thomas, D.C., and Gray, D.R., 2002, Update COSEWIC status report on the woodland caribou Rangifer tarandus caribou in Canada, in COSEWIC assessment and update status report on the Woodland Caribou Rangifer tarandus caribou in Canada: Ottawa, Committee on the Status of Endangered Wildlife in Canada (COSEWIC), p. 1-98.

Thompson, M.C.,Ely, C.A., Gress, B., Otte, C., Patti., S., Seibel, D., and Young, E.A., 2011, Birds of Kansas: Lawrence, University Press of Kansas, 536 p.

Toweill, D.E., and Thomas, J.W., and Metz, D.P., eds., 2002, North American elk-Ecology and management: Washington, D.C., Smithsonian Institution Press, 962 p., 24 pl.

Trani, M.K., Ford, W.M., and Chapman, B.R., eds., 2007, The land manager's guide to mammals of the South: Durham, The Nature Conservancy, Southeastern Region, U.S. Forest Service, 546 p. [Also available at https://www.nrs.fs.fed.us/ pubs/40264.]

Trauth, S.E., Robison, H.W., and Plummer, M.V., 2004, The amphibians and reptiles of Arkansas: University of Arkansas Press, $440 \mathrm{p}$.

U.S. Fish and Wildlife Service (USFWS), 2008, Rice rat (Oryzomys palustris natator) 5-year review-Summary and Evaluation: Vero Beach, Fla., U.S. Fish and Wildlife Service. $26 \mathrm{p}$.

U. S. Fish and Wildlife Service (USFWS), date variable, Endangered species database: U.S. Fish and Wildlife Service, Ecological Services. [Also available at https://www. fws.gov/endangered/species/recovery-plans.html.]
U. S. Fish and Wildlife Service (USFWS), date variable, Environmental Conservation Online Systems (ECOS), U.S. Fish and Wildlife threatened and endangered species critical habitat reports. [Also available at https://ecos.fws.gov/ecp/ report/table/critical-habitat.html.]

U.S. Geological Survey, 2015, North American breeding bird survey, results and analysis (1966-2015), ver. 1.30.2015: U.S. Geological Survey, Patuxent Wildlife Research Center. [Also available at https://www.mbr-pwrc.usgs.gov/bbs/bbs. html.]

Verts, B.J., and Carraway, L.N., 1998, Land mammals of Oregon: Berkeley, University of California Press, 800 p.

Webster, W.D., Parnell, J.F., and Biggs, W.C., Jr., 1985, Mammals of the Carolinas, Virginia, and Maryland: Chapel Hill, The University of North Carolina Press, 272 p.

Werler, J.E., and Dixon, J. R., 2000, Texas snakes-Identification, distribution, and natural history: Austin, University of Texas Press, 544 p.

Whitaker, J.O., Jr., and Hamilton, W.J., Jr., 1998, Mammals of the eastern United States; Ithaca, Cornell University Press, $583 \mathrm{p}$.

Williams, D.F., 1986, Mammalian species of special concern in California: California Department of Fish and Game, Wildlife Management Division Administrative Report 86-1., 112 p. [Also available at https://sdmmp.com/upload/SDMMP_Repository/0/ q432h7cwzp9dbsymx05jg1vrfnk68t.pdf.]

Wilson, D.E., and Reeder, D.M., eds., 2005, Mammal species of the world-A taxonomic and geographic reference (3d ed.): Baltimore, The Johns Hopkins University Press, Baltimore, 2 vol., $142 \mathrm{p}$.

Wilson, D.E., and Ruff, S., 1999, The Smithsonian book of North American mammals: Washington, D.C., Smithsonian Inst. Press, $750 \mathrm{p}$.

Wilson, L.A., 1995, The land manager's guide to the amphibians and reptiles of the South: Chapel Hill, The Nature Conservancy, $324 \mathrm{p}$.

Zeiner, D.C., Laudenslayer, W.F., Jr., Mayer, K.E., and White, M., eds., 1990, California's wildlife, v. 3, Mammals: Sacramento, California Department of Fish and Game, Sacramento. $x i+407$ p. [ Also available at https://www. amazon.com/Californias-Wildlife-Amphibians-ReptilesMammals/dp/B00BRTL8IG.]

Zeveloff, S.I., 1988, Mammals of the intermountain west: Salt Lake City, University of Utah Press, 365 p. 
Zielinski, W.J., Truex, R.L., Schlexer, F.V., Campbell, L.A., and Carroll, C., 2005, Historical and contemporary distributions of carnivores in forests of the Sierra Nevada, California, USA: Journal of Biogeography, v. 32, p. 385-1407. [Also available at https://doi.org/10.1111/ j.1365-2699.2005.01234.x.]

Zielinski, W.J., Schlexer, F.V., Dunk, J.R., Lau M.J., and Graham, J.J., 2015, A range-wide occupancy estimate and habitat model for the endangered Point Arena mountain beaver (Aplodontia rufa nigra): Journal of Mammalogy, v. 96, issue 2, p. 380-393, accessed July 30, 2018, at https://doi. org/10.1093/jmammal/gyv039. 
Table 2.1. List of 129 subspecies for which Gap Analysis Project (GAP) habitat distribution models were created class (amphibia, bird, mammal, reptile). Species listed alphabetically by taxa (dark blue) and scientific name (light blue).

\begin{tabular}{|c|c|c|}
\hline Species code & Subspecies scientific name & Common name \\
\hline \multicolumn{3}{|c|}{ Amphibian } \\
\hline \multicolumn{3}{|c|}{ Cryptobranchus alleganiensis } \\
\hline aHELLa & Cryptobranchus alleganiensis alleganiensis & Eastern Hellbender \\
\hline aHELLb & Cryptobranchus alleganiensis bishopi & Ozark Hellbender \\
\hline \multicolumn{3}{|c|}{ Ammodramus savannarum } \\
\hline bGRSPx & & Grasshopper Sparrow \\
\hline bGRSPf & Ammodramus savannarum floridanus & Florida Grasshopper Sparrow \\
\hline \multicolumn{3}{|c|}{ Amphispiza belli } \\
\hline bSAGSc & Amphispiza belli clementeae & San Clemente Sage Sparrow \\
\hline bSAGSn & Amphispiza belli nevadensis & Great Basin Sage Sparrow \\
\hline \multicolumn{3}{|c|}{ Anser albifrons } \\
\hline bGWFGx & & Greater White-fronted Goose \\
\hline bGWFGe & Anser albifrons elgasi & Tule White-fronted Goose \\
\hline \multicolumn{3}{|c|}{ Athene cunicularia } \\
\hline bBUOWx & & Burrowing Owl \\
\hline bBUOWf & Athene cunicularia floridana & Florida Burrowing Owl \\
\hline bFEPOc & Glaucidium brasilianum cactorum & Cactus Ferruginous Pygmy-owl \\
\hline \multicolumn{3}{|c|}{ Glaucidium gnoma } \\
\hline bNOPOx & & Northern Pygmy-owl \\
\hline bNOPOc & Glaucidium gnoma californicum & Northern Pygmy-owl \\
\hline bNOPOg & Glaucidium gnoma gnoma & Northern Pygmy-owl \\
\hline \multicolumn{3}{|c|}{ Laterallus jamaicensis } \\
\hline bBLRAx & & Black Rail \\
\hline bBLRAc & Laterallus jamaicensis coturniculus & California Black Rail \\
\hline \multicolumn{3}{|c|}{ Meleagris gallopavo } \\
\hline bWITUx & & Wild Turkey \\
\hline bWITUm & Meleagris gallopavo merriami & Merriam’s Turkey \\
\hline bWITUi & Meleagris gallopavo mexicana & Mexican Turkey \\
\hline \multicolumn{3}{|c|}{ Pelecanus occidentalis } \\
\hline bBRPEx & & Brown Pelican \\
\hline
\end{tabular}


Table 2.1. List of 129 subspecies for which GAP habitat distribution models were created class (amphibia, bird, mammal, reptile). Species listed alphabetically by taxa (dark green) and scientific name (light green).-Continued

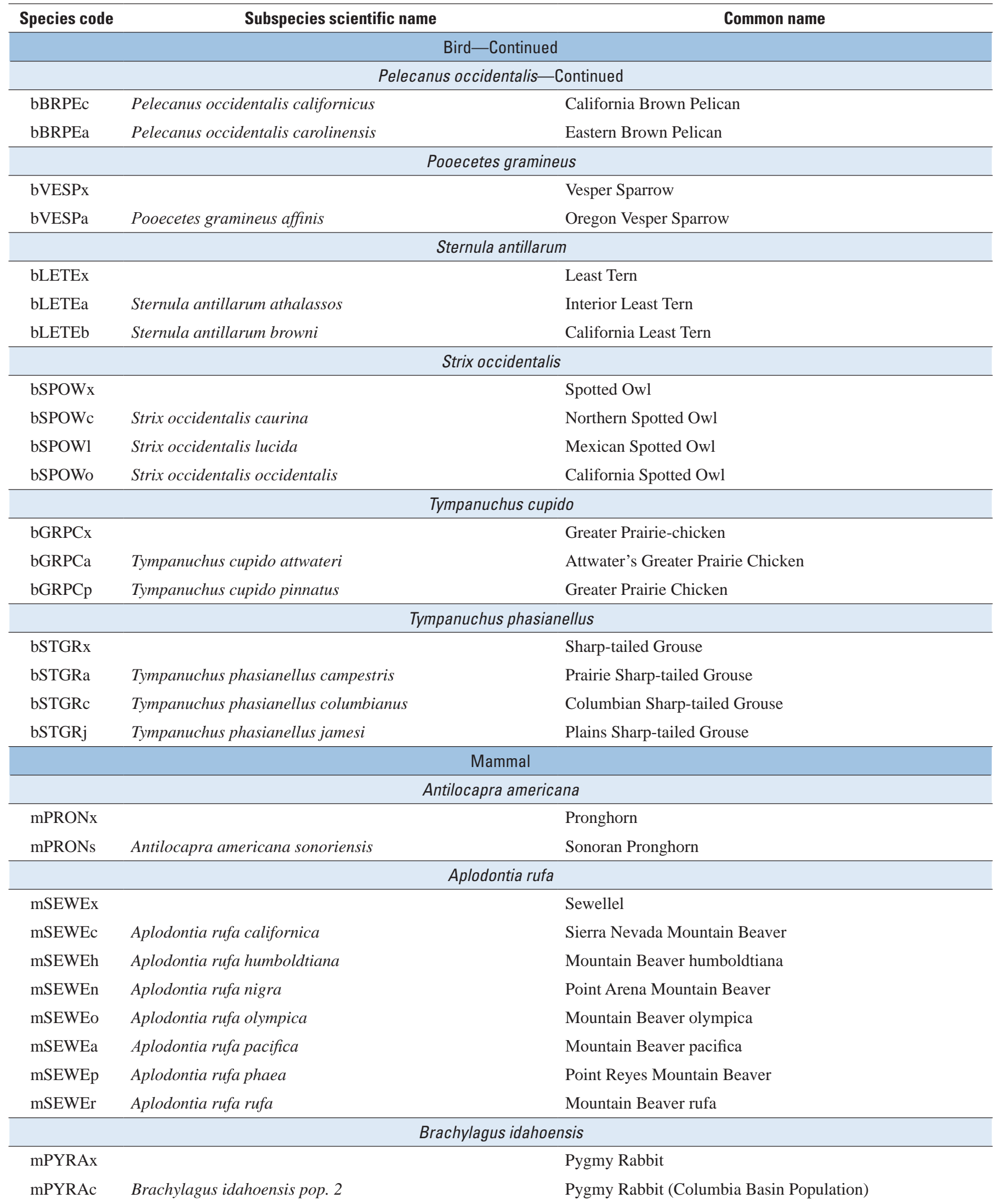


Table 2.1. List of 129 subspecies for which GAP habitat distribution models were created class (amphibia, bird, mammal, reptile). Species listed alphabetically by taxa (dark green) and scientific name (light green)._-Continued

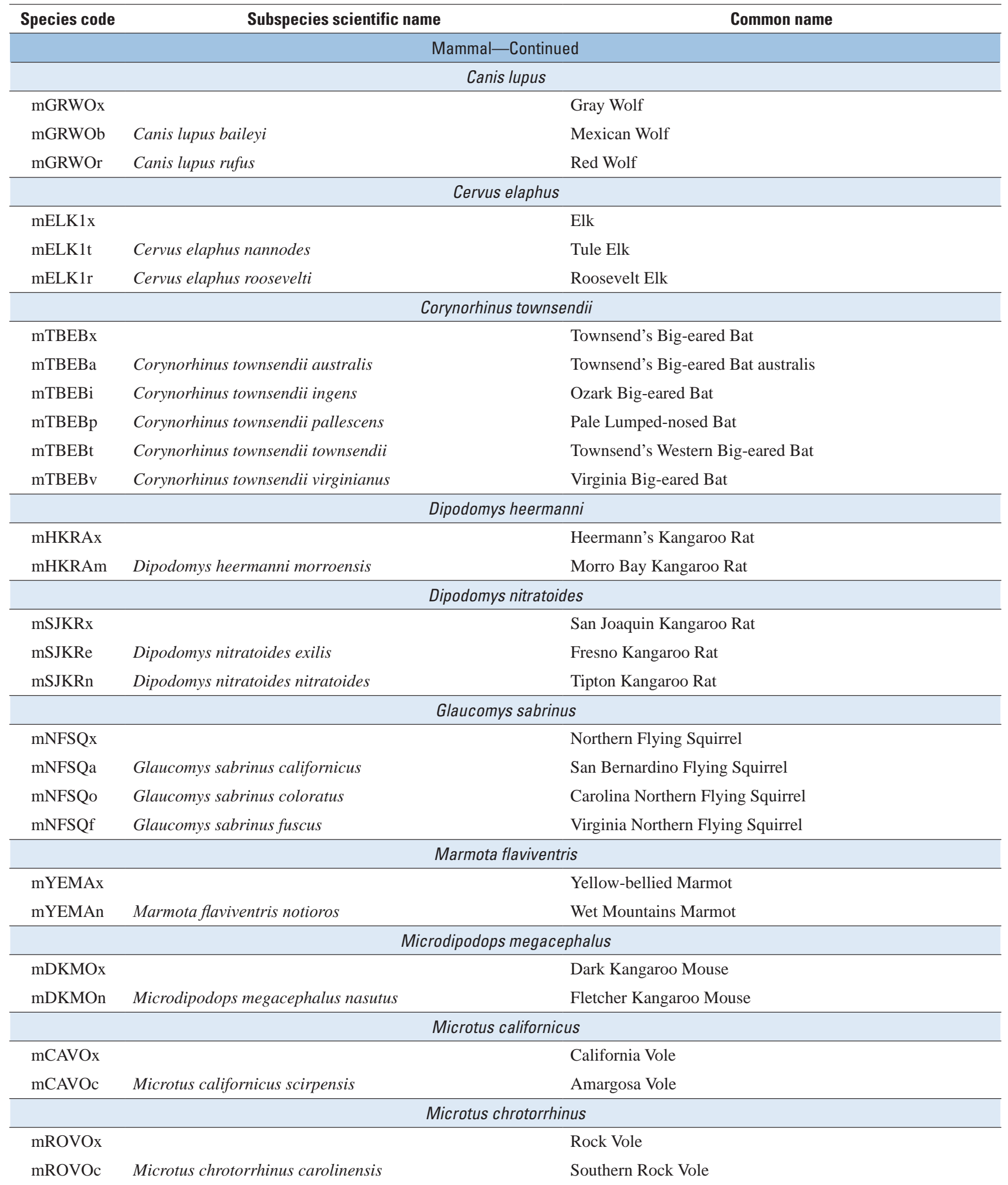


Table 2.1. List of 129 subspecies for which GAP habitat distribution models were created class (amphibia, bird, mammal, reptile). Species listed alphabetically by taxa (dark green) and scientific name (light green).-Continued

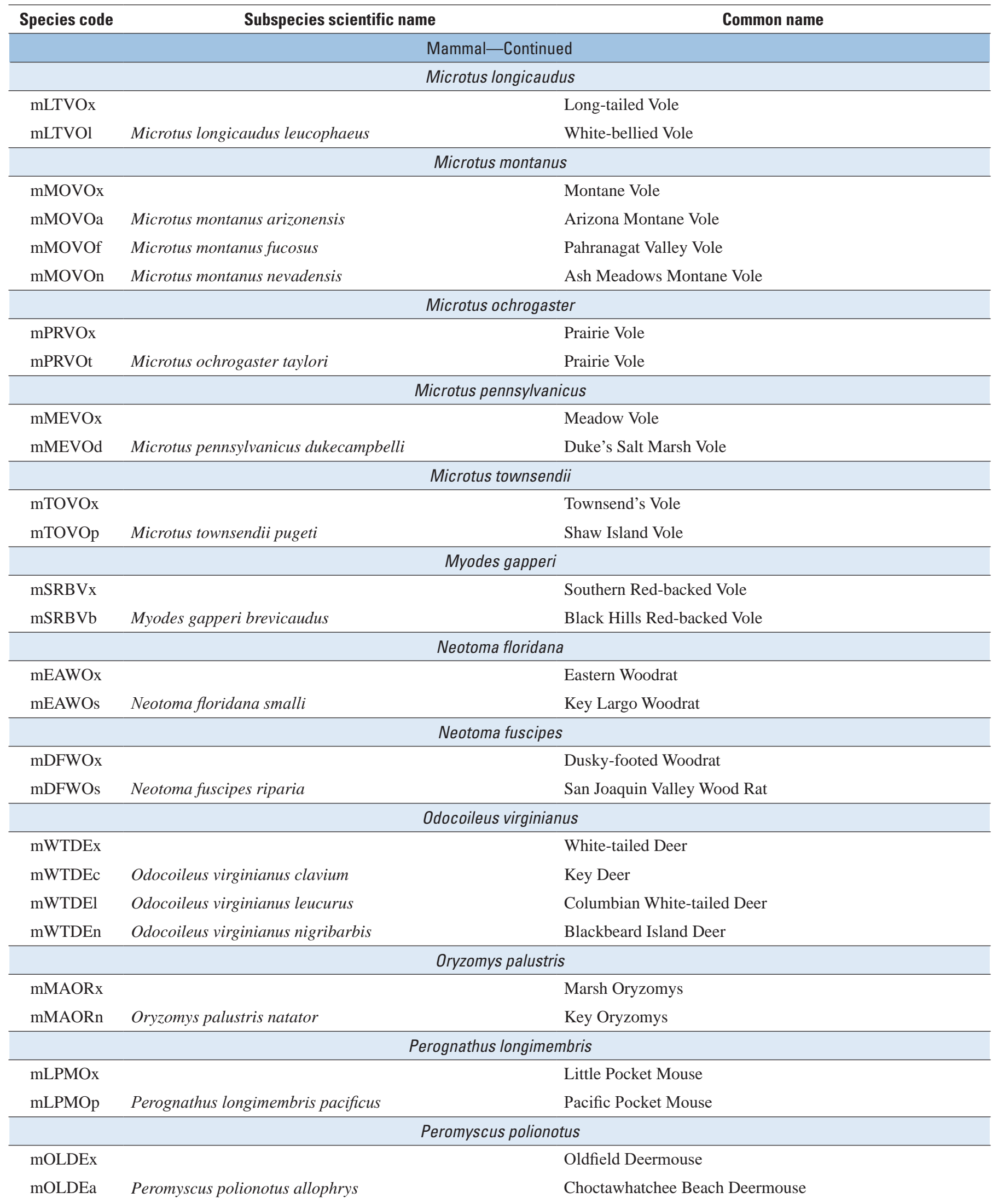


Table 2.1. List of 129 subspecies for which GAP habitat distribution models were created class (amphibia, bird, mammal, reptile). Species listed alphabetically by taxa (dark green) and scientific name (light green)._-Continued

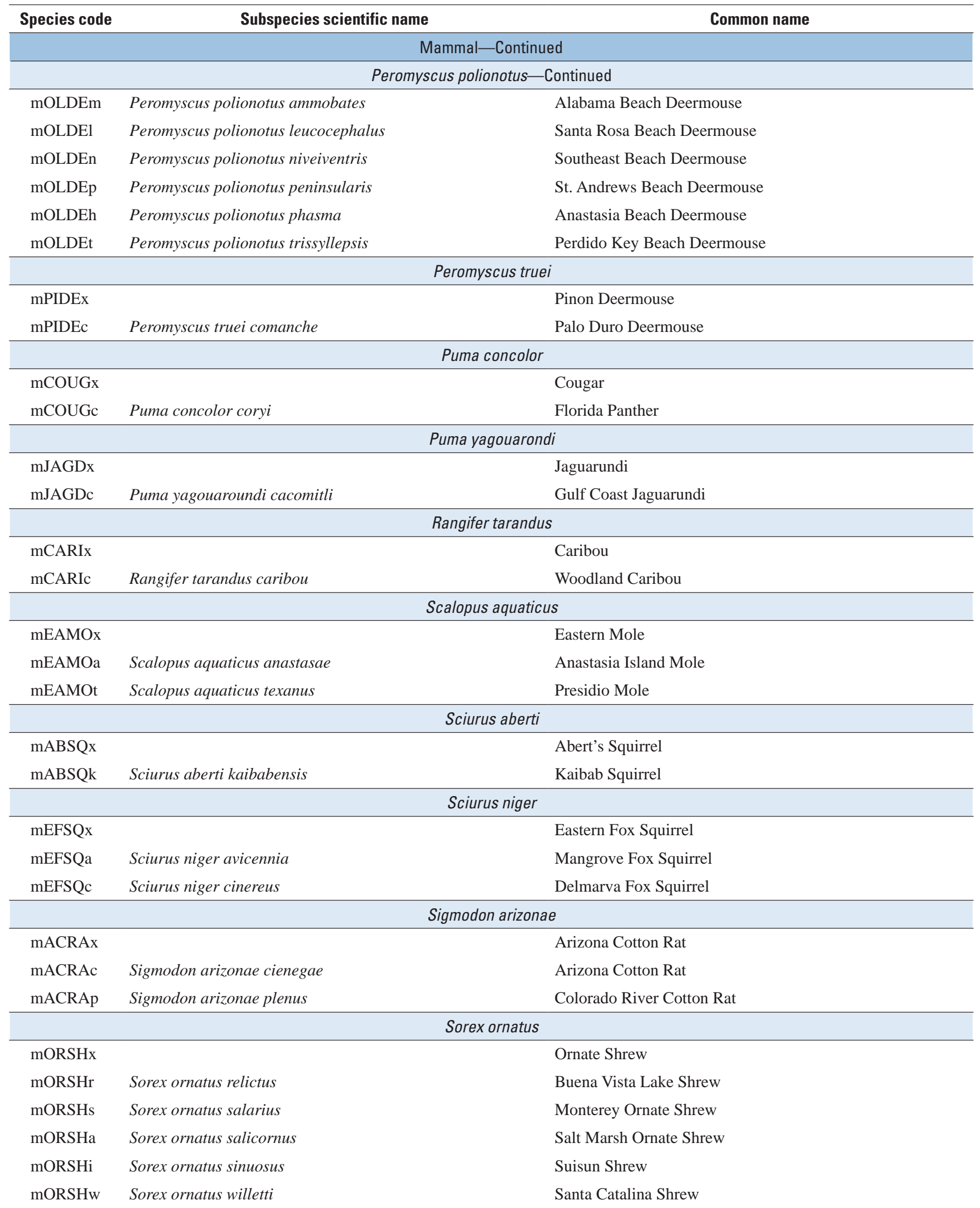


Table 2.1. List of 129 subspecies for which GAP habitat distribution models were created class (amphibia, bird, mammal, reptile). Species listed alphabetically by taxa (dark green) and scientific name (light green).-Continued

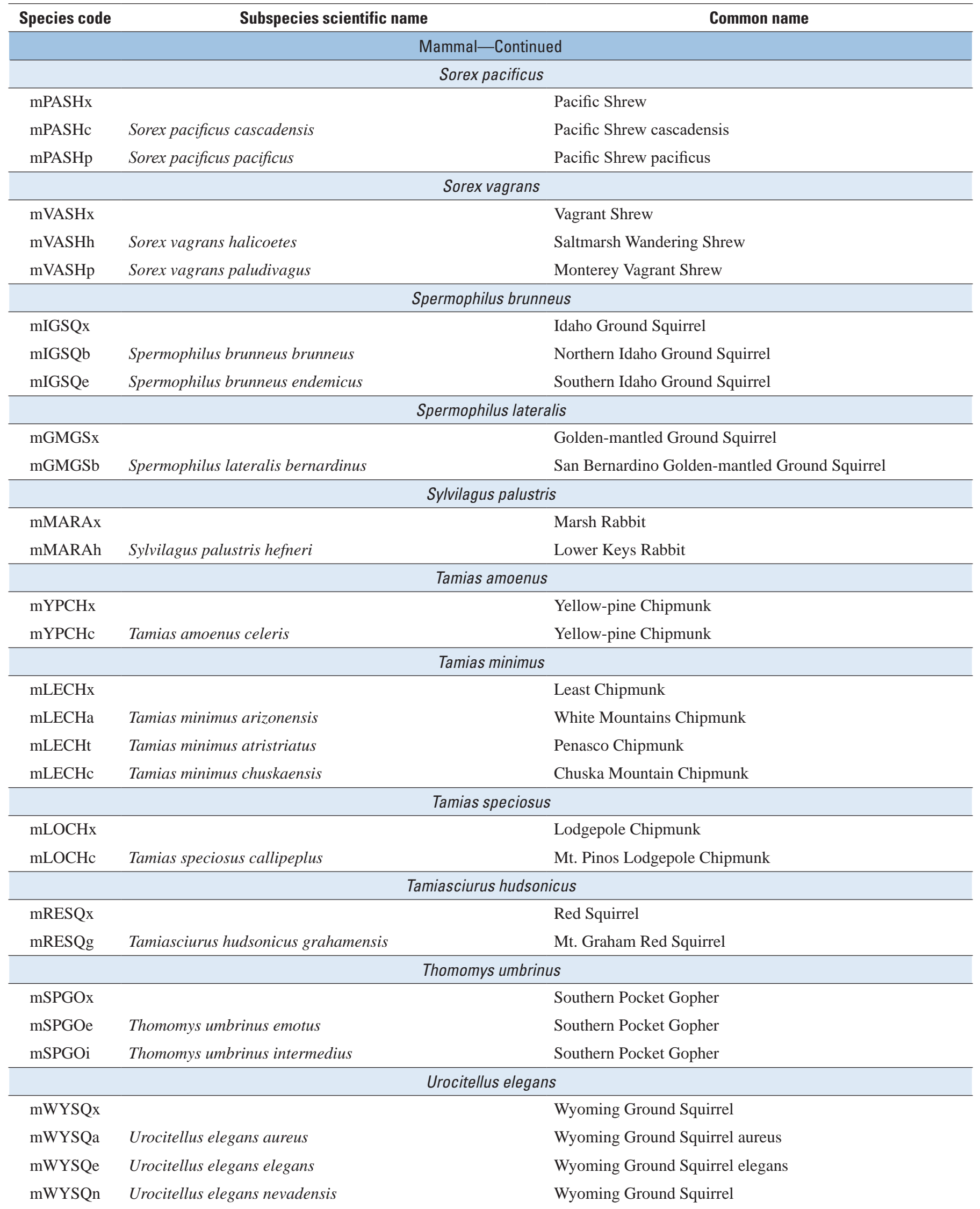


Table 2.1. List of 129 subspecies for which GAP habitat distribution models were created class (amphibia, bird, mammal, reptile). Species listed alphabetically by taxa (dark green) and scientific name (light green)._-Continued

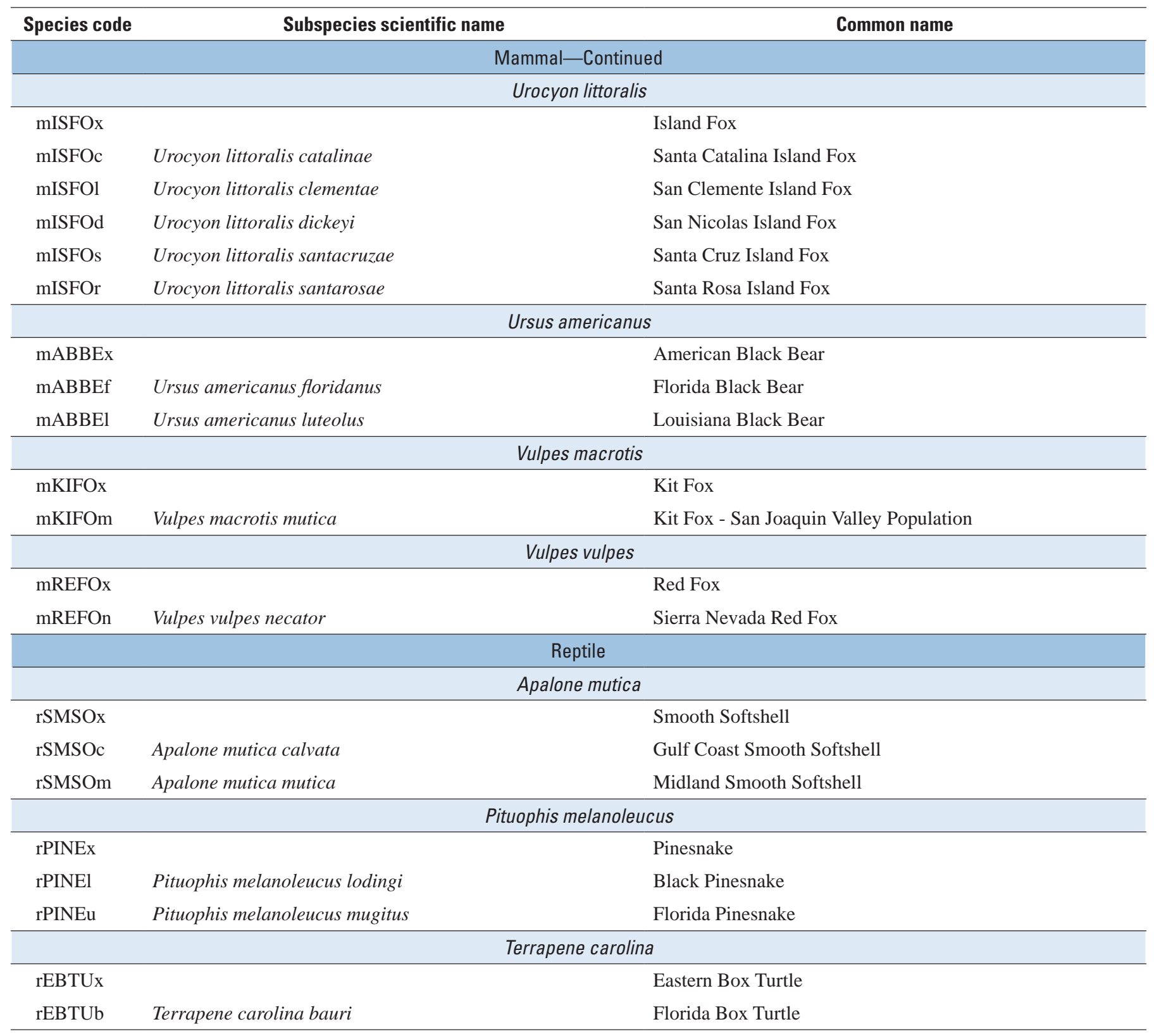




\section{Appendix 3. Table of Notes on Species Taxonomy}

Table 3.1. Notes on species taxonomy related to the Integrated Taxonomic Information System and NatureServe's Global Element Identifiers for species where there was not a direct match with the taxonomic concept being modeled by Gap Analysis Project (GAP).

[ITIS, Integrated Taxonomic Information System; SGW, Steven G. Williams; USFWS, U.S. Fish and Wildlife Service; km, kilometer]

\begin{tabular}{|c|c|c|c|c|c|}
\hline $\begin{array}{l}\text { GAP } \\
\text { species } \\
\text { code }\end{array}$ & GAP common name & GAP scientific name & $\begin{array}{l}\text { Matching } \\
\text { ITIS } \\
\text { code }\end{array}$ & $\begin{array}{c}\text { Matching } \\
\text { NatureServe } \\
\text { Global Element ID }\end{array}$ & Taxa concept matching notes \\
\hline bSTGRx & Sharp-tailed Grouse & $\begin{array}{l}\text { Tympanuchus } \\
\text { phasianellus }\end{array}$ & 175841 & 104212 & $\begin{array}{l}\text { Three subspecies of Tympanuchus phasianellus (Sharp-tailed Grouse) occur in the } \\
\text { United States: Plains T. p. jamesi (Sharp-tailed Grouse), T. p. campestris (Prairie } \\
\text { Sharp-tailed Grouse), and T. p. columbianus (Columbian Sharp-tailed Grouse). } \\
\text { Range distribution is based on Spaulding and others, 2006. T. p. campestris } \\
\text { (Prairie Sharp-tailed Grouse) is not recognized by NatureServe. SGW } 29 \\
\text { September } 2017\end{array}$ \\
\hline bSTGRc & $\begin{array}{l}\text { Columbian Sharp-tailed } \\
\text { Grouse }\end{array}$ & $\begin{array}{l}\text { Tympanuchus } \\
\text { phasianellus } \\
\text { columbianus }\end{array}$ & 175849 & 104539 & $\begin{array}{l}\text { Three subspecies of Tympanuchus phasianellus (Sharp-tailed Grouse) occur in the } \\
\text { United States: T. p. jamesi (Plains Sharp-tailed Grouse), T. p. campestris (Prairie } \\
\text { Sharp-tailed Grouse), and T. p. columbianus (Columbian Sharp-tailed Grouse). } \\
\text { Range distribution is based on Spaulding and others, 2006. T. p. campestris } \\
\text { (Prairie Sharp-tailed Grouse) is not recognized by NatureServe. SGW } 29 \\
\text { September } 2017\end{array}$ \\
\hline bSTGRj & $\begin{array}{l}\text { Plains Sharp-tailed } \\
\text { Grouse }\end{array}$ & $\begin{array}{l}\text { Tympanuchus } \\
\text { phasianellus jamesi }\end{array}$ & 175853 & 100742 & $\begin{array}{l}\text { Three subspecies of Tympanuchus phasianellus (Sharp-tailed Grouse) occur in the } \\
\text { United States: T. p. jamesi (Plains Sharp-tailed Grouse), T. p. campestris (Prairie } \\
\text { Sharp-tailed Grouse), and T. p. columbianus (Columbian Sharp-tailed Grouse). } \\
\text { Range distribution is based on Spaulding and others, 2006. T. p. campestris } \\
\text { (Prairie Sharp-tailed Grouse) is not recognized by NatureServe. SGW } 29 \\
\text { September } 2017\end{array}$ \\
\hline bSTGRa & $\begin{array}{l}\text { Prairie Sharp-tailed } \\
\text { Grouse }\end{array}$ & $\begin{array}{l}\text { Tympanuchus } \\
\text { phasianellus } \\
\text { campestris }\end{array}$ & 175851 & 104212 & $\begin{array}{l}\text { Three subspecies of Tympanuchus phasianellus (Sharp-tailed Grouse) occur in the } \\
\text { United States: T. p. jamesi (Plains Sharp-tailed Grouse), T. p. campestris (Prairie } \\
\text { Sharp-tailed Grouse), and T. p. columbianus (Columbian Sharp-tailed Grouse). } \\
\text { Range distribution is based on Spaulding and others, 2006. T. p. campestris } \\
\text { (Prairie Sharp-tailed Grouse) is not recognized by NatureServe. SGW } 29 \\
\text { September } 2017\end{array}$ \\
\hline bSNPLx & Snowy Plover & Charadrius nivosus & 824030 & 102013 & $\begin{array}{l}\text { Updated GAP scientific name to match ITIS and NatureServe which recognize } \\
\text { Western Hemisphere Charadrius nivosus (Snowy Plovers) as distinct from } \\
\text { Charadrius alexandrinus (Old World Snowy Plovers). SGW } 29 \text { September } 2017\end{array}$ \\
\hline bSNPLn & Western Snowy Plover & $\begin{array}{l}\text { Charadrius nivosus } \\
\text { nivosus }\end{array}$ & 824565 & 100393 & $\begin{array}{l}\text { Updated GAP scientific name to match ITIS and NatureServe which recognize } \\
\text { Western Hemisphere Charadrius nivosus (Snowy Plovers) as distinct from } \\
\text { Charadrius alexandrinus (Old World Snowy Plovers). SGW } 29 \text { September } 2017\end{array}$ \\
\hline
\end{tabular}


Table 3.1. Notes on species taxonomy related to the Integrated Taxonomic Information System and NatureServe's Global Element Identifiers for species where there was not a direct match with the taxonomic concept being modeled by Gap Analysis Project (GAP).-Continued

[ITIS, Integrated Taxonomic Information System; SGW, Steven G. Williams; USFWS, U.S. Fish and Wildlife Service; km, kilometer]

\begin{tabular}{|c|c|c|c|c|c|}
\hline $\begin{array}{l}\text { GAP } \\
\text { species } \\
\text { code }\end{array}$ & GAP common name & GAP scientific name & $\begin{array}{l}\text { Matching } \\
\text { ITIS } \\
\text { code }\end{array}$ & $\begin{array}{c}\text { Matching } \\
\text { NatureServe } \\
\text { Global Element ID }\end{array}$ & Taxa concept matching notes \\
\hline bSAGSx & Sage Sparrow & Amphispiza belli & 997724 & 104426 & $\begin{array}{l}\text { The Artemisiospiza belli (Sage Sparrow) has been the subject of much debate about } \\
\text { its taxonomic status. As of May 2013, the species is comprised of five subspecies } \\
\text { which occur in the U.S. (A. b. belli, A. } \text { b. canescens, A. } b \text {. cinerea, A. } b \text {. } \\
\text { clementeae, A. } b \text {. nevadensis). A. } b \text {. nevadensis is likely to be elevated to species } \\
\text { status. We mapped four subspecies based on distinct ranges and conservation } \\
\text { concern. Both NatureServe and ITIS recognize this genus as Artemisiospiza } \\
\text { and recognize Amphispiza belli nevadensis as a distinct species (Artemisiospiza } \\
\text { nevadensis). Furthermore, NatureServe does not recognize Amphispiza belli } \\
\text { canescens as a subspecies. SGW } 29 \text { September } 2017\end{array}$ \\
\hline bSAGSb & Bell’s Sage Sparrow & Amphispiza belli belli & 998052 & 101203 & $\begin{array}{l}\text { The Artemisiospiza belli (Sage Sparrow) has been the subject of much debate about } \\
\text { its taxonomic status. As of May 2013, the species is comprised of five subspecies } \\
\text { which occur in the U.S. (A. } b \text {. belli, A. } b \text {. canescens, A. } b \text {. cinerea, A. } b \text {. } \\
\text { clementeae, A. } b \text {. nevadensis). A. } b \text {. nevadensis is likely to be elevated to species } \\
\text { status. We mapped four subspecies based on distinct ranges and conservation } \\
\text { concern. Both NatureServe and ITIS recognize this genus as Artemisiospiza } \\
\text { and recognize Amphispiza belli nevadensis as a distinct species (Artemisiospiza } \\
\text { nevadensis). Furthermore, NatureServe does not recognize Amphispiza belli } \\
\text { canescens as a subspecies. SGW } 29 \text { September } 2017\end{array}$ \\
\hline bSAGSc & $\begin{array}{l}\text { San Clemente Sage } \\
\text { Sparrow }\end{array}$ & $\begin{array}{l}\text { Amphispiza belli } \\
\text { clementeae }\end{array}$ & 998053 & 100803 & $\begin{array}{l}\text { The Artemisiospiza belli (Sage Sparrow) has been the subject of much debate about } \\
\text { its taxonomic status. As of May 2013, the species is comprised of five subspecies } \\
\text { which occur in the U.S. (A. } b \text {. belli, A. } b \text {. canescens, A. } b \text {. cinerea, A. } b \text {. } \\
\text { clementeae, A. } b \text {. nevadensis). A. } \text { b. nevadensis is likely to be elevated to species } \\
\text { status. We mapped four subspecies based on distinct ranges and conservation } \\
\text { concern. Both NatureServe and ITIS recognize this genus as Artemisiospiza } \\
\text { and recognize Amphispiza belli nevadensis as a distinct species (Artemisiospiza } \\
\text { nevadensis). Furthermore, NatureServe does not recognize Amphispiza belli } \\
\text { canescens as a subspecies. SGW } 29 \text { September } 2017\end{array}$ \\
\hline bSAGSa & Saltbush Sparrow & $\begin{array}{l}\text { Amphispiza belli } \\
\text { canescens }\end{array}$ & 998051 & 104426 & $\begin{array}{l}\text { The Artemisiospiza belli (Sage Sparrow) has been the subject of much debate about } \\
\text { its taxonomic status. As of May 2013, the species is comprised of five subspecies } \\
\text { which occur in the U.S. (A. } b \text {. belli, A. } b \text {. canescens, A. } \text { b. cinerea, } A \text {. } b \text {. } \\
\text { clementeae, A. } b \text {. nevadensis). A. } b \text {. nevadensis is likely to be elevated to species } \\
\text { status. We mapped four subspecies based on distinct ranges and conservation } \\
\text { concern. Both NatureServe and ITIS recognize this genus as Artemisiospiza } \\
\text { and recognize Amphispiza belli nevadensis as a distinct species (Artemisiospiza } \\
\text { nevadensis). Furthermore, NatureServe does not recognize Amphispiza belli } \\
\text { canescens as a subspecies. SGW } 29 \text { September } 2017\end{array}$ \\
\hline
\end{tabular}


Table 3.1. Notes on species taxonomy related to the Integrated Taxonomic Information System and NatureServe's Global Element Identifiers for species where there was not a direct match with the taxonomic concept being modeled by Gap Analysis Project (GAP).-Continued

[ITIS, Integrated Taxonomic Information System; SGW, Steven G. Williams; USFWS, U.S. Fish and Wildlife Service; km, kilometer]

\begin{tabular}{|c|c|c|c|c|c|}
\hline $\begin{array}{l}\text { GAP } \\
\text { species } \\
\text { code }\end{array}$ & GAP common name & GAP scientific name & $\begin{array}{l}\text { Matching } \\
\text { ITIS } \\
\text { code }\end{array}$ & $\begin{array}{c}\text { Matching } \\
\text { NatureServe } \\
\text { Global Element ID }\end{array}$ & Taxa concept matching notes \\
\hline bSAGSn & $\begin{array}{l}\text { Great Basin Sage } \\
\text { Sparrow }\end{array}$ & $\begin{array}{l}\text { Amphispiza belli } \\
\text { nevadensis }\end{array}$ & 997723 & 902215 & $\begin{array}{l}\text { The Artemisiospiza belli (Sage Sparrow) has been the subject of much debate about } \\
\text { its taxonomic status. As of May 2013, the species is comprised of five subspecies } \\
\text { which occur in the U.S. (A. } b \text {. belli, A. } b \text {. canescens, A. } b \text {. cinerea, A. } b \text {. } \\
\text { clementeae, A. } b \text {. nevadensis). A. } b \text {. nevadensis is likely to be elevated to species } \\
\text { status. We mapped four subspecies based on distinct ranges and conservation } \\
\text { concern. Both NatureServe and ITIS recognize this genus as Artemisiospiza } \\
\text { and recognize Amphispiza belli nevadensis as a distinct species (Artemisiospiza } \\
\text { nevadensis). Furthermore, NatureServe does not recognize Amphispiza belli } \\
\text { canescens as a subspecies. SGW } 29 \text { September } 2017\end{array}$ \\
\hline mEAMOx & Eastern Mole & Scalopus aquaticus & 179979 & 106146 & $\begin{array}{l}\text { Three subspecies of Scalopus aquaticus (Eastern Mole) are recognized by } \\
\text { NatureServe and have a Rounded Global Status of T1 - Critically Imperiled (S. } \\
\text { a. anastasae, S. a. bassi, and S. a. texanus). However, only S. a. anastasae and S. } \\
\text { a. texanus have isolated ranges separate from the full species. Therefore, a range } \\
\text { and model for S. a. anastasae and S. a. texanus were created and S. a. bassi was } \\
\text { removed from the modeling list. SGW } 29 \text { September } 2017\end{array}$ \\
\hline mEAMOa & Anastasia Island Mole & $\begin{array}{l}\text { Scalopus aquaticus } \\
\text { anastasae }\end{array}$ & 709992 & 104966 & $\begin{array}{l}\text { Three subspecies of Scalopus aquaticus (Eastern Mole) are recognized by } \\
\text { NatureServe and have a Rounded Global Status of T1 - Critically Imperiled (S. } \\
\text { a. anastasae, S. a. bassi, and S. a. texanus). However, only S. a. anastasae and S. } \\
\text { a. texanus have isolated ranges separate from the full species. Therefore, a range } \\
\text { and model for S. a. anastasae and S. a. texanus were created and S. a. bassi was } \\
\text { removed from the modeling list. SGW } 29 \text { September } 2017\end{array}$ \\
\hline mEAMOt & Presidio Mole & $\begin{array}{l}\text { Scalopus aquaticus } \\
\quad \text { texanus }\end{array}$ & 710005 & 103457 & $\begin{array}{l}\text { Three subspecies of Scalopus aquaticus (Eastern Mole) are recognized by } \\
\text { NatureServe and have a Rounded Global Status of T1 - Critically Imperiled (S. } \\
\text { a. anastasae, S. a. bassi, and S. a. texanus). However, only S. a. anastasae and S. } \\
\text { a. texanus have isolated ranges separate from the full species. Therefore, a range } \\
\text { and model for S. a. anastasae and S. a. texanus were created and S. a. bassi was } \\
\text { removed from the modeling list. SGW } 29 \text { September } 2017\end{array}$ \\
\hline mCLOBx & $\begin{array}{l}\text { Curasoan Long-nosed } \\
\text { Bat }\end{array}$ & Leptonycteris curasoae & 552464 & 106286 & $\begin{array}{l}\text { NatureServe recognize Leptonycteris curasoae as part of Leptonycteris } \\
\text { yerbabuenae. SGW } 29 \text { September } 2017\end{array}$ \\
\hline mTBEBx & $\begin{array}{l}\text { Townsend's Big-eared } \\
\text { Bat }\end{array}$ & $\begin{array}{l}\text { Corynorhinus } \\
\text { townsendii }\end{array}$ & 203452 & 103228 & $\begin{array}{l}\text { There are five subspecies of Corynorhinus townsendii and the eastern most ones, } \\
\text { C. t. virginianus and C. t. ingens are listed as Endangered under the Endangered } \\
\text { Species Act of } 1979 \text { (Piaggio and others, 2009). The eastern subspecies ranges } \\
\text { are based on information in Conservation and Management of Eastern Big Eared } \\
\text { Bats (Loeb and others, 2011). Western subspecies ranges were derived from } \\
\text { Ammerman and others, (2012) Smith and others (2008), Pierson and Rainey } \\
\text { (1998), and Piaggio and Perkins (2005). C. t. australis is not recognized by } \\
\text { NatureServe. SGW } 29 \text { September } 2017\end{array}$ \\
\hline
\end{tabular}


Table 3.1. Notes on species taxonomy related to the Integrated Taxonomic Information System and NatureServe's Global Element Identifiers for species where there was not a direct match with the taxonomic concept being modeled by Gap Analysis Project (GAP).-Continued

[ITIS, Integrated Taxonomic Information System; SGW, Steven G. Williams; USFWS, U.S. Fish and Wildlife Service; km, kilometer]

\begin{tabular}{|c|c|c|c|c|c|}
\hline $\begin{array}{l}\text { GAP } \\
\text { species } \\
\text { code }\end{array}$ & GAP common name & GAP scientific name & $\begin{array}{l}\text { Matching } \\
\text { ITIS } \\
\text { code }\end{array}$ & $\begin{array}{c}\text { Matching } \\
\text { NatureServe } \\
\text { Global Element ID }\end{array}$ & Taxa concept matching notes \\
\hline mTBEBi & Ozark Big-eared Bat & $\begin{array}{l}\text { Corynorhinus } \\
\text { townsendii ingens }\end{array}$ & 632276 & 104608 & $\begin{array}{l}\text { There are five subspecies of Corynorhinus townsendii and the eastern most ones, } \\
\text { C. t. virginianus and C. t. ingens are listed as Endangered under the Endangered } \\
\text { Species Act of } 1979 \text { (Piaggio and others, 2009). The eastern subspecies ranges } \\
\text { are based on information in Conservation and Management of Eastern Big Eared } \\
\text { Bats (Loeb and others, 2011). Western subspecies ranges were derived from } \\
\text { Ammerman and others (2012) Smith and others (2008), Pierson and Rainey } \\
\text { (1998), and Piaggio and Perkins (2005). C. t. australis is not recognized by } \\
\text { NatureServe. SGW } 29 \text { September 2017 }\end{array}$ \\
\hline mTBEBv & Virginia Big-eared Bat & $\begin{array}{c}\text { Corynorhinus } \\
\text { townsendii } \\
\text { virginianus }\end{array}$ & 203454 & 100716 & $\begin{array}{l}\text { There are five subspecies of Corynorhinus townsendii and the eastern most ones, } \\
\text { C. t. virginianus and C. t. ingens are listed as Endangered under the Endangered } \\
\text { Species Act of } 1979 \text { (Piaggio and others, 2009). The eastern subspecies ranges } \\
\text { are based on information in Conservation and Management of Eastern Big Eared } \\
\text { Bats (Loeb and others, 2011). Western subspecies ranges were derived from } \\
\text { Ammerman and others (2012) Smith and others (2008), Pierson and Rainey } \\
\text { (1998), and Piaggio and Perkins (2005). C. t. australis is not recognized by } \\
\text { NatureServe. SGW } 29 \text { September 2017 }\end{array}$ \\
\hline mTBEBp & Pale Lumped-nosed Bat & $\begin{array}{l}\text { Corynorhinus } \\
\text { townsendii pallescens }\end{array}$ & 203458 & 105024 & $\begin{array}{l}\text { There are five subspecies of Corynorhinus townsendii and the eastern most ones, } \\
\text { C. t. virginianus and C. t. ingens are listed as Endangered under the Endangered } \\
\text { Species Act of } 1979 \text { (Piaggio and others, 2009). The eastern subspecies ranges } \\
\text { are based on information in Conservation and Management of Eastern Big Eared } \\
\text { Bats (Loeb and others, 2011). Western subspecies ranges were derived from } \\
\text { Ammerman and others (2012) Smith and others (2008), Pierson and Rainey } \\
\text { (1998), and Piaggio and Perkins (2005). C. t. australis is not recognized by } \\
\text { NatureServe. SGW } 29 \text { September 2017 }\end{array}$ \\
\hline mTBEBt & $\begin{array}{l}\text { Townsend’s Western } \\
\text { Big-eared Bat }\end{array}$ & $\begin{array}{c}\text { Corynorhinus } \\
\text { townsendii } \\
\text { townsendii }\end{array}$ & 203453 & 106329 & $\begin{array}{l}\text { There are five subspecies of Corynorhinus townsendii and the eastern most ones, } \\
\text { C. t. virginianus and C. t. ingens are listed as Endangered under the Endangered } \\
\text { Species Act of } 1979 \text { (Piaggio and others, 2009). The eastern subspecies ranges } \\
\text { are based on information in Conservation and Management of Eastern Big Eared } \\
\text { Bats (Loeb and others, 2011). Western subspecies ranges were derived from } \\
\text { Ammerman and others (2012) Smith and others (2008), Pierson and Rainey } \\
\text { (1998), and Piaggio and Perkins (2005). C. t. australis is not recognized by } \\
\text { NatureServe. SGW } 29 \text { September 2017 }\end{array}$ \\
\hline
\end{tabular}


Table 3.1. Notes on species taxonomy related to the Integrated Taxonomic Information System and NatureServe's Global Element Identifiers for species where there was not a direct match with the taxonomic concept being modeled by Gap Analysis Project (GAP).-Continued

[ITIS, Integrated Taxonomic Information System; SGW, Steven G. Williams; USFWS, U.S. Fish and Wildlife Service; km, kilometer]

\begin{tabular}{|c|c|c|c|c|c|}
\hline $\begin{array}{l}\text { GAP } \\
\text { species } \\
\text { code }\end{array}$ & GAP common name & GAP scientific name & $\begin{array}{l}\text { Matching } \\
\text { ITIS } \\
\text { code }\end{array}$ & $\begin{array}{l}\text { Matching } \\
\text { NatureServe } \\
\text { Global Element ID }\end{array}$ & Taxa concept matching notes \\
\hline mTBEBa & $\begin{array}{l}\text { Big-eared Bat } \\
\quad \text { (australis) }\end{array}$ & $\begin{array}{l}\text { Corynorhinus } \\
\text { townsendii australis }\end{array}$ & 632279 & 103228 & $\begin{array}{l}\text { There are five subspecies of Corynorhinus townsendii and the eastern most ones, } \\
\text { C. t. virginianus and C. t. ingens are listed as Endangered under the Endangered } \\
\text { Species Act of } 1979 \text { (Piaggio and others, 2009). The eastern subspecies ranges } \\
\text { are based on information in Conservation and Management of Eastern Big Eared } \\
\text { Bats (Loeb and others, 2011). Western subspecies ranges were derived from } \\
\text { Ammerman and others (2012) Smith and others (2008), Pierson and Rainey } \\
\text { (1998), and Piaggio and Perkins (2005). C. t. australis is not recognized by } \\
\text { NatureServe. SGW } 29 \text { September } 2017\end{array}$ \\
\hline mWBBAx & Wagner's Bonneted Bat & Eumops glaucinus & 180079 & 104958 & $\begin{array}{l}\text { Eumops glaucinus is not recognized by NatureServe as a species, but rather as part } \\
\text { of Eumops floridanus. SGW } 29 \text { September } 2017\end{array}$ \\
\hline mPYRAx & Pygmy Rabbit & Brachylagus idahoensis & 552521 & 102656 & $\begin{array}{l}\text { NatureServe recognizes a distinct subpopulation of Brachylagus idahoensis as } \\
\text { Population. } 2 \text { with the common name of Columbia Basin Pygmy Rabbit. ITIS } \\
\text { does not recognize any subpopulations. SGW } 29 \text { September } 2017\end{array}$ \\
\hline mPYRAc & $\begin{array}{l}\text { Pygmy Rabbit } \\
\text { (Columbia Basin } \\
\text { Population) }\end{array}$ & $\begin{array}{l}\text { Brachylagus idahoensis } \\
\quad \text { population } 2\end{array}$ & 552521 & 637957 & $\begin{array}{l}\text { NatureServe recognizes a distinct subpopulation of Brachylagus idahoensis as } \\
\text { Population } 2 \text { with the common name of Columbia Basin Pygmy Rabbit. ITIS does } \\
\text { not recognize any subpopulations. SGW } 29 \text { September } 2017\end{array}$ \\
\hline mSEWEx & Sewellel & Aplodontia rufa & 180133 & 101780 & $\begin{array}{l}\text { The Aplondontia rufa (Sewellel), also called the Mountain Beaver, occurs in } \\
\text { the Sierra Nevadas, Coastal California, and parts of the Pacific Northwest. } \\
\text { Piaggio and others (2013) provided a revised assessment of the geography of } \\
\text { its subspecies and delineated the ranges of seven subspecies: } A \text {. r. pacifica, A. } r \text {. } \\
\text { californica, A. r. humboldtiana, A. r. nigra, A. r. phaea, A. r. olympica, and A. } r \text {. } \\
\text { rufa. They also concluded that } A \text {. } r \text {. pacifica may be a unique species. ITIS does } \\
\text { not recognize A. } r \text {. olympica as a subspecies. NatureServe does not recognize A. } r \text {. } \\
\text { humboldtiana or } A \text {. r. pacifica. SGW } 29 \text { September } 2017\end{array}$ \\
\hline mSEWEn & $\begin{array}{l}\text { Point Arena Mountain } \\
\text { Beaver }\end{array}$ & Aplodontia rufa nigra & 202351 & 104721 & $\begin{array}{l}\text { The Aplondontia rufa (Sewellel), also called the Mountain Beaver, occurs in } \\
\text { the Sierra Nevadas, Coastal California, and parts of the Pacific Northwest. } \\
\text { Piaggio and others (2013) provided a revised assessment of the geography of } \\
\text { its subspecies and delineated the ranges of seven subspecies: } \text { A. r. pacifica, A. } r \text {. } \\
\text { californica, A. r. humboldtiana, A. r. nigra, A. r. phaea, A. r. olympica, and A. } r \text {. } \\
\text { rufa. They also concluded that } A \text {. r. pacifica may be a unique species. ITIS does } \\
\text { not recognize A. r. olympica as a subspecies. NatureServe does not recognize A. r. } \\
\text { humboldtiana or } \text { A. r. pacifica. SGW } 29 \text { September } 2017\end{array}$ \\
\hline
\end{tabular}


Table 3.1. Notes on species taxonomy related to the Integrated Taxonomic Information System and NatureServe's Global Element Identifiers for species where there was not a direct match with the taxonomic concept being modeled by Gap Analysis Project (GAP).-Continued

[ITIS, Integrated Taxonomic Information System; SGW, Steven G. Williams; USFWS, U.S. Fish and Wildlife Service; km, kilometer]

\begin{tabular}{|c|c|c|c|c|c|}
\hline $\begin{array}{l}\text { GAP } \\
\text { species } \\
\text { code }\end{array}$ & GAP common name & GAP scientific name & $\begin{array}{l}\text { Matching } \\
\text { ITIS } \\
\text { code }\end{array}$ & $\begin{array}{c}\text { Matching } \\
\text { NatureServe } \\
\text { Global Element ID }\end{array}$ & Taxa concept matching notes \\
\hline mSEWEp & $\begin{array}{l}\text { Point Reyes Mountain } \\
\text { Beaver }\end{array}$ & Aplodontia rufa phaea & 203477 & 100536 & $\begin{array}{l}\text { The Aplondontia rufa (Sewellel), also called the Mountain Beaver, occurs in } \\
\text { the Sierra Nevadas, Coastal California, and parts of the Pacific Northwest. } \\
\text { Piaggio and others (2013) provided a revised assessment of the geography of } \\
\text { its subspecies and delineated the ranges of seven subspecies: } A \text {. } r \text {. pacifica, A. } r \text {. } \\
\text { californica, A. } r \text {. humboldtiana, A. r. nigra, A. r. phaea, A. r. olympica, and A. } r \text {. } \\
\text { rufa. They also concluded that } A \text {. r. pacifica may be a unique species. ITIS does } \\
\text { not recognize A. r. olympica as a subspecies. NatureServe does not recognize } A . r \text {. } \\
\text { humboldtiana or } \text { A. r. pacifica. SGW } 29 \text { September } 2017\end{array}$ \\
\hline mSEWEc & $\begin{array}{l}\text { Sierra Nevada } \\
\quad \text { Mountain Beaver }\end{array}$ & $\begin{array}{l}\text { Aplodontia rufa } \\
\text { californica }\end{array}$ & 203471 & 101050 & 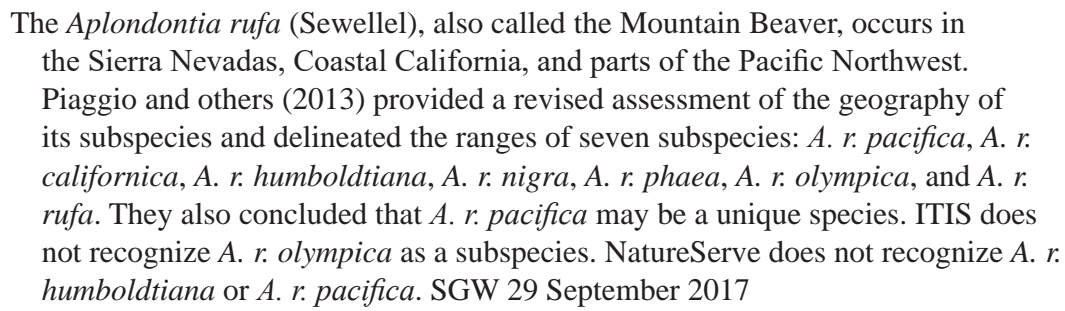 \\
\hline mSEWEr & $\begin{array}{l}\text { Coastal Mountain } \\
\text { Beaver }\end{array}$ & Aplodontia rufa rufa & 202350 & 102374 & $\begin{array}{l}\text { The Aplondontia rufa (Sewellel), also called the Mountain Beaver, occurs in } \\
\text { the Sierra Nevadas, Coastal California, and parts of the Pacific Northwest. } \\
\text { Piaggio and others (2013) provided a revised assessment of the geography of } \\
\text { its subspecies and delineated the ranges of seven subspecies: } A \text {. } r \text {. pacifica, A. } r \text {. } \\
\text { californica, A. } r \text {. humboldtiana, A. r. nigra, A. r. phaea, A. } r \text {. olympica, and A. } r \text {. } \\
\text { rufa. They also concluded that } A \text {. } r \text {. pacifica may be a unique species. ITIS does } \\
\text { not recognize A. } r \text {. olympica as a subspecies. NatureServe does not recognize } A . r \text {. } \\
\text { humboldtiana or } A \text {. } r \text { pacifica. SGW } 29 \text { September } 2017\end{array}$ \\
\hline mSEWEo & $\begin{array}{l}\text { Olympic Mountain } \\
\text { Beaver }\end{array}$ & $\begin{array}{l}\text { Aplodontia rufa } \\
\text { olympica }\end{array}$ & 180133 & 894467 & $\begin{array}{l}\text { The Aplondontia rufa (Sewellel), also called the Mountain Beaver, occurs in } \\
\text { the Sierra Nevadas, Coastal California, and parts of the Pacific Northwest. } \\
\text { Piaggio and others (2013) provided a revised assessment of the geography of } \\
\text { its subspecies and delineated the ranges of seven subspecies: } A \text {. } r \text {. pacifica, A. } r \text {. } \\
\text { californica, A. r. humboldtiana, A. r. nigra, A. r. phaea, A. r. olympica, and A. } r \text {. } \\
\text { rufa. They also concluded that } A \text {. r. pacifica may be a unique species. ITIS does } \\
\text { not recognize A. } r \text {. olympica as a subspecies. NatureServe does not recognize A. } r \text {. } \\
\text { humboldtiana or } A \text {. r. pacifica. SGW } 29 \text { September } 2017\end{array}$ \\
\hline
\end{tabular}


Table 3.1. Notes on species taxonomy related to the Integrated Taxonomic Information System and NatureServe's Global Element Identifiers for species where there was not a direct match with the taxonomic concept being modeled by Gap Analysis Project (GAP).-Continued

[ITIS, Integrated Taxonomic Information System; SGW, Steven G. Williams; USFWS, U.S. Fish and Wildlife Service; km, kilometer]

\begin{tabular}{|c|c|c|c|c|c|}
\hline $\begin{array}{l}\text { GAP } \\
\text { species } \\
\text { code }\end{array}$ & GAP common name & GAP scientific name & $\begin{array}{l}\text { Matching } \\
\text { ITIS } \\
\text { code }\end{array}$ & $\begin{array}{c}\text { Matching } \\
\text { NatureServe } \\
\text { Global Element ID }\end{array}$ & Taxa concept matching notes \\
\hline mSEWEa & $\begin{array}{l}\text { Mountain Beaver } \\
\text { pacifica }\end{array}$ & Aplodontia rufa pacifica & 203475 & 101780 & $\begin{array}{l}\text { The Aplondontia rufa (Sewellel), also called the Mountain Beaver, occurs in } \\
\text { the Sierra Nevadas, Coastal California, and parts of the Pacific Northwest. } \\
\text { Piaggio and others (2013) provided a revised assessment of the geography of } \\
\text { its subspecies and delineated the ranges of seven subspecies: } \text { A. r. pacifica, A. } r \text {. } \\
\text { californica, A. r. humboldtiana, A. r. nigra, A. r. phaea, A. r. olympica, and A. } r \text {. } \\
\text { rufa. They also concluded that } A \text {. r. pacifica may be a unique species. ITIS does } \\
\text { not recognize A. r. olympica as a subspecies. NatureServe does not recognize A. } r \text {. } \\
\text { humboldtiana or } A \text {. r. pacifica. SGW } 29 \text { September } 2017\end{array}$ \\
\hline mSEWEh & $\begin{array}{l}\text { Mountain Beaver } \\
\text { humboldtiana }\end{array}$ & $\begin{array}{l}\text { Aplodontia rufa } \\
\text { humboldtiana }\end{array}$ & 203473 & 101780 & $\begin{array}{l}\text { The Aplondontia rufa (Sewellel), also called the Mountain Beaver, occurs in } \\
\text { the Sierra Nevadas, Coastal California, and parts of the Pacific Northwest. } \\
\text { Piaggio and others (2013) provided a revised assessment of the geography of } \\
\text { its subspecies and delineated the ranges of seven subspecies: } \text { A. r. pacifica, A. } r \text {. } \\
\text { californica, A. } r \text {. humboldtiana, A. r. nigra, A. r. phaea, A. r. olympica, and A. } r \text {. } \\
\text { rufa. They also concluded that } A \text {. r. pacifica may be a unique species. ITIS does } \\
\text { not recognize A. r. olympica as a subspecies. NatureServe does not recognize A. r. } \\
\text { humboldtiana or } A \text {. r. pacifica. SGW } 29 \text { September } 2017\end{array}$ \\
\hline mALCHx & Alpine Chipmunk & Tamias alpinus & 180189 & 102392 & $\begin{array}{l}\text { NatureServe recognizes Tamias genus as NeoTamias (except Tamias striatus) based } \\
\text { on Baker and others (2003). SGW } 29 \text { September } 2017\end{array}$ \\
\hline mLECHx & Least Chipmunk & Tamias minimus & 180195 & 103812 & $\begin{array}{l}\text { NatureServe recognizes Tamias genus as NeoTamias (except Tamias striatus) based } \\
\text { on Baker and others (2003). SGW } 29 \text { September } 2017\end{array}$ \\
\hline mLECHt & Penasco Chipmunk & $\begin{array}{l}\text { Tamias minimus } \\
\text { atristriatus }\end{array}$ & 632531 & 102143 & $\begin{array}{l}\text { NatureServe recognizes Tamias genus as NeoTamias (except Tamias striatus) based } \\
\text { on Baker and others (2003). SGW } 29 \text { September } 2017\end{array}$ \\
\hline mLECHc & $\begin{array}{l}\text { Chuska Mountain } \\
\text { Chipmunk }\end{array}$ & $\begin{array}{l}\text { Tamias minimus } \\
\text { chuskaensis }\end{array}$ & 931310 & 102895 & $\begin{array}{l}\text { NatureServe recognizes Tamias genus as NeoTamias (except Tamias striatus) based } \\
\text { on Baker and others (2003). SGW } 29 \text { September } 2017\end{array}$ \\
\hline mLECHa & $\begin{array}{l}\text { White Mountains } \\
\text { Chipmunk }\end{array}$ & $\begin{array}{l}\text { Tamias minimus } \\
\text { arizonensis }\end{array}$ & 931309 & 103851 & $\begin{array}{l}\text { NatureServe recognizes Tamias genus as NeoTamias (except Tamias striatus) based } \\
\text { on Baker and others (2003). SGW } 29 \text { September } 2017\end{array}$ \\
\hline mYPCHx & Yellow-pine Chipmunk & Tamias amoenus & 180190 & 103853 & $\begin{array}{l}\text { NatureServe recognizes Tamias genus as NeoTamias (except Tamias striatus) based } \\
\text { on Baker and others (2003). SGW } 29 \text { September } 2017\end{array}$ \\
\hline mYPCHc & $\begin{array}{l}\text { Yellow-pine Chipmunk } \\
\text { (celeris) }\end{array}$ & Tamias amoenus celeris & 931137 & 101472 & $\begin{array}{l}\text { NatureServe recognizes Tamias genus as NeoTamias (except Tamias striatus) based } \\
\text { on Baker and others (2003). SGW } 29 \text { September } 2017\end{array}$ \\
\hline mTOCHx & Townsend's Chipmunk & Tamias townsendii & 180208 & 105861 & $\begin{array}{l}\text { NatureServe recognizes Tamias genus as NeoTamias (except Tamias striatus) based } \\
\text { on Baker and others (2003). SGW } 29 \text { September } 2017\end{array}$ \\
\hline mYCCHx & $\begin{array}{l}\text { Yellow-cheeked } \\
\text { Chipmunk }\end{array}$ & Tamias ochrogenys & 180197 & 102756 & $\begin{array}{l}\text { NatureServe recognizes Tamias genus as NeoTamias (except Tamias striatus) based } \\
\text { on Baker and others (2003). SGW } 29 \text { September } 2017\end{array}$ \\
\hline
\end{tabular}


Table 3.1. Notes on species taxonomy related to the Integrated Taxonomic Information System and NatureServe's Global Element Identifiers for species where there was not a direct match with the taxonomic concept being modeled by Gap Analysis Project (GAP).-Continued

[ITIS, Integrated Taxonomic Information System; SGW, Steven G. Williams; USFWS, U.S. Fish and Wildlife Service; km, kilometer]

\begin{tabular}{|c|c|c|c|c|c|}
\hline $\begin{array}{l}\text { GAP } \\
\text { species } \\
\text { code }\end{array}$ & GAP common name & GAP scientific name & $\begin{array}{l}\text { Matching } \\
\text { ITIS } \\
\text { code }\end{array}$ & $\begin{array}{c}\text { Matching } \\
\text { NatureServe } \\
\text { Global Element ID }\end{array}$ & Taxa concept matching notes \\
\hline mSHCHx & Shadow Chipmunk & Tamias senex & 180203 & 102290 & $\begin{array}{l}\text { NatureServe recognizes Tamias genus as NeoTamias (except Tamias striatus) based } \\
\text { on Baker and others (2003). SGW } 29 \text { September } 2017\end{array}$ \\
\hline mSICHx & Siskiyou Chipmunk & Tamias siskiyou & 180204 & 101954 & $\begin{array}{l}\text { NatureServe recognizes Tamias genus as NeoTamias (except Tamias striatus) based } \\
\text { on Baker and others (2003). SGW } 29 \text { September } 2017\end{array}$ \\
\hline mSOCHx & Sonoma Chipmunk & Tamias sonomae & 180205 & 101465 & $\begin{array}{l}\text { NatureServe recognizes Tamias genus as NeoTamias (except Tamias striatus) based } \\
\text { on Baker and others (2003). SGW } 29 \text { September } 2017\end{array}$ \\
\hline mMMCHx & Merriam’s Chipmunk & Tamias merriami & 180194 & 101063 & $\begin{array}{l}\text { NatureServe recognizes Tamias genus as NeoTamias (except Tamias striatus) based } \\
\text { on Baker and others (2003). SGW } 29 \text { September } 2017\end{array}$ \\
\hline mCFCHx & California Chipmunk & Tamias obscurus & 180196 & 101062 & $\begin{array}{l}\text { NatureServe recognizes Tamias genus as NeoTamias (except Tamias striatus) based } \\
\text { on Baker and others (2003). SGW } 29 \text { September } 2017\end{array}$ \\
\hline mCLCHx & Cliff Chipmunk & Tamias dorsalis & 180193 & 103986 & $\begin{array}{l}\text { NatureServe recognizes Tamias genus as NeoTamias (except Tamias striatus) based } \\
\text { on Baker and others (2003). SGW } 29 \text { September } 2017\end{array}$ \\
\hline $\mathrm{mCOCHx}$ & Colorado Chipmunk & Tamias quadrivittatus & 180201 & 103893 & $\begin{array}{l}\text { NatureServe recognizes Tamias genus as NeoTamias (except Tamias striatus) based } \\
\text { on Baker and others (2003). SGW } 29 \text { September } 2017\end{array}$ \\
\hline mRTCHx & Red-tailed Chipmunk & Tamias ruficaudus & 180202 & 105876 & $\begin{array}{l}\text { NatureServe recognizes Tamias genus as NeoTamias (except Tamias striatus) based } \\
\text { on Baker and others (2003). SGW } 29 \text { September } 2017\end{array}$ \\
\hline mGCCHx & $\begin{array}{l}\text { Gray-collared } \\
\text { Chipmunk }\end{array}$ & Tamias cinereicollis & 180192 & 102849 & $\begin{array}{l}\text { NatureServe recognizes Tamias genus as NeoTamias (except Tamias striatus) based } \\
\text { on Baker and others (2003). SGW } 29 \text { September } 2017\end{array}$ \\
\hline mGFCHx & Gray-footed Chipmunk & Tamias canipes & 180191 & 101405 & $\begin{array}{l}\text { NatureServe recognizes Tamias genus as NeoTamias (except Tamias striatus) based } \\
\text { on Baker and others (2003). SGW } 29 \text { September } 2017\end{array}$ \\
\hline mLOECx & Long-eared Chipmunk & $\begin{array}{l}\text { Tamias } \\
\text { quadrimaculatus }\end{array}$ & 180200 & 100740 & $\begin{array}{l}\text { NatureServe recognizes Tamias genus as NeoTamias (except Tamias striatus) based } \\
\text { on Baker and others (2003). SGW } 29 \text { September } 2017\end{array}$ \\
\hline mLOCHx & Lodgepole Chipmunk & Tamias speciosus & 180206 & 105567 & $\begin{array}{l}\text { NatureServe recognizes Tamias genus as NeoTamias (except Tamias striatus) based } \\
\text { on Baker and others (2003). The southern portion of the subspecies Tamias } \\
\text { speciosus speciosus' range is disjunct from the full species range in the extreme } \\
\text { southern Sierra Nevadas, however, the northern portion in Tulare and Inyo } \\
\text { counties appear not to be (based on Grinnell } 1913 \text { as stated in NatureServe). } \\
\text { Additionally, this subspecies appears to be of no immediate conservation concern } \\
\text { according to NatureServe and Williams (1986). The range of subspecies T.s. } \\
\text { callipeplus (Mt. Pinos Lodgepole Chipmunk), however, is truly disjunct and } \\
\text { restricted to the Mount Pinos area, Ventura County, California (Wilson and Ruff } \\
\text { 1999) and the nearby Mt. Abel (about } 6 \text { km distant) and Mt. Frazier. Also, it is } \\
\text { listed as T1-critically imperiled by NatureServe rounded global status. Therefore, } \\
\text { T.s. speciosus was removed from the model list and T.s. callipeplus was retained. } \\
\text { SGW } 29 \text { September } 2017\end{array}$ \\
\hline
\end{tabular}


Table 3.1. Notes on species taxonomy related to the Integrated Taxonomic Information System and NatureServe's Global Element Identifiers for species where there was not a direct match with the taxonomic concept being modeled by Gap Analysis Project (GAP).-Continued

[ITIS, Integrated Taxonomic Information System; SGW, Steven G. Williams; USFWS, U.S. Fish and Wildlife Service; km, kilometer]

\begin{tabular}{|c|c|c|c|c|c|}
\hline $\begin{array}{l}\text { GAP } \\
\text { species } \\
\text { code }\end{array}$ & GAP common name & GAP scientific name & $\begin{array}{l}\text { Matching } \\
\text { ITIS } \\
\text { code }\end{array}$ & $\begin{array}{l}\text { Matching } \\
\text { NatureServe } \\
\text { Global Element ID }\end{array}$ & Taxa concept matching notes \\
\hline mLOCHc & $\begin{array}{l}\text { Mt. Pinos Lodgepole } \\
\text { Chipmunk }\end{array}$ & $\begin{array}{l}\text { Tamias speciosus } \\
\text { callipeplus }\end{array}$ & 931198 & 105202 & $\begin{array}{l}\text { NatureServe recognizes Tamias genus as NeoTamias (except Tamias striatus) based } \\
\text { on Baker and others (2003). The southern portion of the subspecies Tamias } \\
\text { speciosus speciosus' range is disjunct from the full species range in the extreme } \\
\text { southern Sierra Nevadas, however, the northern portion in Tulare and Inyo } \\
\text { counties appear not to be (based on Grinnell } 1913 \text { as stated in NatureServe). } \\
\text { Additionally, this subspecies appears to be of no immediate conservation concern } \\
\text { according to NatureServe and Williams (1986). The range of subspecies T.s. } \\
\text { callipeplus (Mt. Pinos Lodgepole Chipmunk), however, is truly disjunct and } \\
\text { restricted to the Mount Pinos area, Ventura County, California (Wilson and Ruff } \\
\text { 1999) and the nearby Mt. Abel (about } 6 \text { km distant) and Mt. Frazier. Also, it is } \\
\text { listed as T1-critically imperiled by NatureServe rounded global status. Therefore, } \\
\text { T.s. speciosus was removed from the model list and T.s. callipeplus was retained. } \\
\text { SGW } 29 \text { September } 2017\end{array}$ \\
\hline mPNCHx & Panamint Chipmunk & Tamias panamintinus & 180199 & 100573 & $\begin{array}{l}\text { NatureServe recognizes Tamias genus as NeoTamias (except Tamias striatus) based } \\
\text { on Baker and others (2003). SGW } 29 \text { September } 2017\end{array}$ \\
\hline mUICHx & Uinta Chipmunk & Tamias umbrinus & 180209 & 104775 & $\begin{array}{l}\text { NatureServe recognizes Tamias genus as NeoTamias (except Tamias striatus) based } \\
\text { on Baker and others (2003). SGW } 29 \text { September } 2017\end{array}$ \\
\hline mPACHx & Palmer’s Chipmunk & Tamias palmeri & 180198 & 104774 & $\begin{array}{l}\text { NatureServe recognizes Tamias genus as NeoTamias (except Tamias striatus) based } \\
\text { on Baker and others (2003). SGW } 29 \text { September } 2017\end{array}$ \\
\hline mHOCHx & Hopi Chipmunk & Tamias rufus & 552503 & 106127 & $\begin{array}{l}\text { NatureServe recognizes Tamias genus as NeoTamias (except Tamias striatus) based } \\
\text { on Baker and others (2003). SGW } 29 \text { September } 2017\end{array}$ \\
\hline mYEMAx & Yellow-bellied Marmot & Marmota flaviventris & 180140 & 104002 & $\begin{array}{l}\text { The subspecies Marmota flaviventris notioros (Wet Mountains Marmot) was mapped } \\
\text { individually due to its distinct non-overlapping range. SGW } 29 \text { September } 2017\end{array}$ \\
\hline mYEMAn & Wet Mountains Marmot & $\begin{array}{l}\text { Marmota flaviventris } \\
\text { notioros }\end{array}$ & 931015 & 101177 & $\begin{array}{l}\text { The subspecies Marmota flaviventris notioros (Wet Mountains Marmot) was mapped } \\
\text { individually due to its distinct non-overlapping range. SGW } 29 \text { September } 2017\end{array}$ \\
\hline mTGSQx & $\begin{array}{l}\text { Townsend’s Ground } \\
\text { Squirrel }\end{array}$ & Urocitellus townsendii & 930323 & 102480 & $\begin{array}{l}\text { ITIS and NatureServe recognize the splitting of } 8 \text { genera (Notocitellus, } \\
\text { Otospermophilus, Callospermophilus, Ictidomys, Poliocitellus, Xerospermophilus, } \\
\text { and Urocitellus) from Spermophilus (which is now restricted to Eurasia) based on } \\
\text { Helgen and others (2009). SGW } 29 \text { September } 2017\end{array}$ \\
\hline mWASQx & $\begin{array}{l}\text { Washington Ground } \\
\text { Squirrel }\end{array}$ & Urocitellus washingtoni & 930325 & 101353 & $\begin{array}{l}\text { ITIS and NatureServe recognize the splitting of } 8 \text { genera (Notocitellus, } \\
\text { Otospermophilus, Callospermophilus, Ictidomys, Poliocitellus, Xerospermophilus, } \\
\text { and Urocitellus) from Spermophilus (which is now restricted to Eurasia) based on } \\
\text { Helgen and others (2009). SGW } 29 \text { September } 2017\end{array}$ \\
\hline
\end{tabular}


Table 3.1. Notes on species taxonomy related to the Integrated Taxonomic Information System and NatureServe's Global Element Identifiers for species where there was not a direct match with the taxonomic concept being modeled by Gap Analysis Project (GAP).-Continued

[ITIS, Integrated Taxonomic Information System; SGW, Steven G. Williams; USFWS, U.S. Fish and Wildlife Service; km, kilometer]

\begin{tabular}{|c|c|c|c|c|c|}
\hline $\begin{array}{l}\text { GAP } \\
\text { species } \\
\text { code }\end{array}$ & GAP common name & GAP scientific name & $\begin{array}{l}\text { Matching } \\
\text { ITIS } \\
\text { code }\end{array}$ & $\begin{array}{c}\text { Matching } \\
\text { NatureServe } \\
\text { Global Element ID }\end{array}$ & Taxa concept matching notes \\
\hline mIGSQx & Idaho Ground Squirrel & Urocitellus brunneus & 930316 & 100453 & $\begin{array}{l}\text { ITIS and NatureServe recognize the splitting of } 8 \text { genera (Notocitellus, } \\
\text { Otospermophilus, Callospermophilus, Ictidomys, Poliocitellus, Xerospermophilus, } \\
\text { and Urocitellus) from Spermophilus (which is now restricted to Eurasia) based on } \\
\text { Helgen and others (2009). SGW } 29 \text { September } 2017\end{array}$ \\
\hline mIGSQb & $\begin{array}{l}\text { Northern Idaho Ground } \\
\text { Squirrel }\end{array}$ & $\begin{array}{l}\text { Urocitellus brunneus } \\
\text { brunneus }\end{array}$ & 931245 & 102796 & $\begin{array}{l}\text { ITIS and NatureServe recognize the splitting of } 8 \text { genera (Notocitellus, } \\
\text { Otospermophilus, Callospermophilus, Ictidomys, Poliocitellus, Xerospermophilus, } \\
\text { and Urocitellus) from Spermophilus (which is now restricted to Eurasia) based on } \\
\text { Helgen and others (2009). SGW } 29 \text { September } 2017\end{array}$ \\
\hline mIGSQe & $\begin{array}{l}\text { Southern Idaho Ground } \\
\text { Squirrel }\end{array}$ & $\begin{array}{l}\text { Urocitellus brunneus } \\
\text { endemicus }\end{array}$ & 931232 & 104618 & $\begin{array}{l}\text { ITIS and NatureServe recognize the splitting of } 8 \text { genera (Notocitellus, } \\
\text { Otospermophilus, Callospermophilus, Ictidomys, Poliocitellus, Xerospermophilus, } \\
\text { and Urocitellus) from Spermophilus (which is now restricted to Eurasia) based on } \\
\text { Helgen and others (2009). SGW } 29 \text { September } 2017\end{array}$ \\
\hline mRGSQx & $\begin{array}{l}\text { Richardson's Ground } \\
\text { Squirrel }\end{array}$ & Urocitellus richardsonii & 930322 & 100987 & $\begin{array}{l}\text { ITIS and NatureServe recognize the splitting of } 8 \text { genera (Notocitellus, } \\
\text { Otospermophilus, Callospermophilus, Ictidomys, Poliocitellus, Xerospermophilus, } \\
\text { and Urocitellus) from Spermophilus (which is now restricted to Eurasia) based on } \\
\text { Helgen and others (2009). SGW } 29 \text { September } 2017\end{array}$ \\
\hline mUGSQx & Uinta Ground Squirrel & Urocitellus armatus & 930314 & 104586 & $\begin{array}{l}\text { ITIS and NatureServe recognize the splitting of } 8 \text { genera (Notocitellus, } \\
\text { Otospermophilus, Callospermophilus, Ictidomys, Poliocitellus, Xerospermophilus, } \\
\text { and Urocitellus) from Spermophilus (which is now restricted to Eurasia) based on } \\
\text { Helgen and others (2009). SGW } 29 \text { September } 2017\end{array}$ \\
\hline mBGSQx & $\begin{array}{l}\text { Belding's Ground } \\
\text { Squirrel }\end{array}$ & Urocitellus beldingi & 930315 & 104604 & $\begin{array}{l}\text { ITIS and NatureServe recognize the splitting of } 8 \text { genera (Notocitellus, } \\
\text { Otospermophilus, Callospermophilus, Ictidomys, Poliocitellus, Xerospermophilus, } \\
\text { and Urocitellus) from Spermophilus (which is now restricted to Eurasia) based on } \\
\text { Helgen and others (2009). SGW } 29 \text { September } 2017\end{array}$ \\
\hline mCOSQx & $\begin{array}{l}\text { Columbian Ground } \\
\text { Squirrel }\end{array}$ & Urocitellus columbianus & 930318 & 103644 & $\begin{array}{l}\text { ITIS and NatureServe recognize the splitting of } 8 \text { genera (Notocitellus, } \\
\text { Otospermophilus, Callospermophilus, Ictidomys, Poliocitellus, Xerospermophilus, } \\
\text { and Urocitellus) from Spermophilus (which is now restricted to Eurasia) based on } \\
\text { Helgen and others (2009). SGW } 29 \text { September } 2017\end{array}$ \\
\hline mTLGSx & $\begin{array}{l}\text { Thirteen-lined Ground } \\
\text { Squirrel }\end{array}$ & $\begin{array}{l}\text { Ictidomys } \\
\text { tridecemlineatus }\end{array}$ & 930308 & 100397 & $\begin{array}{l}\text { ITIS and NatureServe recognize the splitting of } 8 \text { genera (Notocitellus, } \\
\text { Otospermophilus, Callospermophilus, Ictidomys, Poliocitellus, Xerospermophilus, } \\
\text { and Urocitellus) from Spermophilus (which is now restricted to Eurasia) based on } \\
\text { Helgen and others (2009). SGW } 29 \text { September } 2017\end{array}$ \\
\hline mMESQx & $\begin{array}{l}\text { Mexican Ground } \\
\text { Squirrel }\end{array}$ & Ictidomys mexicanus & 930307 & 100396 & $\begin{array}{l}\text { ITIS and NatureServe recognize the splitting of } 8 \text { genera (Notocitellus, } \\
\text { Otospermophilus, Callospermophilus, Ictidomys, Poliocitellus, Xerospermophilus, } \\
\text { and Urocitellus) from Spermophilus (which is now restricted to Eurasia) based on } \\
\text { Helgen and others (2009). SGW } 29 \text { September } 2017\end{array}$ \\
\hline
\end{tabular}


Table 3.1. Notes on species taxonomy related to the Integrated Taxonomic Information System and NatureServe's Global Element Identifiers for species where there was not a direct match with the taxonomic concept being modeled by Gap Analysis Project (GAP).-Continued

[ITIS, Integrated Taxonomic Information System; SGW, Steven G. Williams; USFWS, U.S. Fish and Wildlife Service; km, kilometer]

\begin{tabular}{|c|c|c|c|c|c|}
\hline $\begin{array}{l}\text { GAP } \\
\text { species } \\
\text { code }\end{array}$ & GAP common name & GAP scientific name & $\begin{array}{l}\text { Matching } \\
\text { ITIS } \\
\text { code }\end{array}$ & $\begin{array}{c}\text { Matching } \\
\text { NatureServe } \\
\text { Global Element ID }\end{array}$ & Taxa concept matching notes \\
\hline mSGSQx & $\begin{array}{l}\text { Spotted Ground } \\
\text { Squirrel }\end{array}$ & $\begin{array}{l}\text { Xerospermophilus } \\
\text { spilosoma }\end{array}$ & 930312 & 100684 & $\begin{array}{l}\text { ITIS and NatureServe recognize the splitting of } 8 \text { genera (Notocitellus, } \\
\text { Otospermophilus, Callospermophilus, Ictidomys, Poliocitellus, Xerospermophilus, } \\
\text { and Urocitellus) from Spermophilus (which is now restricted to Eurasia) based on } \\
\text { Helgen and others (2009). SGW } 29 \text { September } 2017\end{array}$ \\
\hline mFGSQx & $\begin{array}{l}\text { Franklin’s Ground } \\
\text { Squirrel }\end{array}$ & Poliocitellus franklinii & 930309 & 105759 & $\begin{array}{l}\text { ITIS and NatureServe recognize the splitting of } 8 \text { genera (Notocitellus, } \\
\text { Otospermophilus, Callospermophilus, Ictidomys, Poliocitellus, Xerospermophilus, } \\
\text { and Urocitellus) from Spermophilus (which is now restricted to Eurasia) based on } \\
\text { Helgen and others (2009). SGW } 29 \text { September } 2017\end{array}$ \\
\hline mROSQx & Rock Squirrel & $\begin{array}{l}\text { Otospermophilus } \\
\text { variegatus }\end{array}$ & 930302 & 102556 & $\begin{array}{l}\text { ITIS and NatureServe recognize the splitting of } 8 \text { genera (Notocitellus, } \\
\text { Otospermophilus, Callospermophilus, Ictidomys, Poliocitellus, Xerospermophilus, } \\
\text { and Urocitellus) from Spermophilus (which is now restricted to Eurasia) based on } \\
\text { Helgen and others (2009). SGW } 29 \text { September } 2017\end{array}$ \\
\hline mCASQx & $\begin{array}{l}\text { California Ground } \\
\text { Squirrel }\end{array}$ & $\begin{array}{l}\text { Otospermophilus } \\
\text { beecheyi }\end{array}$ & 930301 & 103839 & $\begin{array}{l}\text { ITIS and NatureServe recognize the splitting of } 8 \text { genera (Notocitellus, } \\
\text { Otospermophilus, Callospermophilus, Ictidomys, Poliocitellus, Xerospermophilus, } \\
\text { and Urocitellus) from Spermophilus (which is now restricted to Eurasia) based on } \\
\text { Helgen and others (2009). SGW } 29 \text { September } 2017\end{array}$ \\
\hline mMOSQx & $\begin{array}{l}\text { Mohave Ground } \\
\text { Squirrel }\end{array}$ & $\begin{array}{l}\text { Xerospermophilus } \\
\text { mohavensis }\end{array}$ & 930310 & 103905 & $\begin{array}{l}\text { ITIS and NatureServe recognize the splitting of } 8 \text { genera (Notocitellus, } \\
\text { Otospermophilus, Callospermophilus, Ictidomys, Poliocitellus, Xerospermophilus, } \\
\text { and Urocitellus) from Spermophilus (which is now restricted to Eurasia) based on } \\
\text { Helgen and others (2009). SGW } 29 \text { September } 2017\end{array}$ \\
\hline mRTGSx & $\begin{array}{l}\text { Round-tailed Ground } \\
\text { Squirrel }\end{array}$ & $\begin{array}{l}\text { Xerospermophilus } \\
\text { tereticaudus }\end{array}$ & 930313 & 103413 & $\begin{array}{l}\text { ITIS and NatureServe recognize the splitting of } 8 \text { genera (Notocitellus, } \\
\text { Otospermophilus, Callospermophilus, Ictidomys, Poliocitellus, Xerospermophilus, } \\
\text { and Urocitellus) from Spermophilus (which is now restricted to Eurasia) based on } \\
\text { Helgen and others (2009). SGW } 29 \text { September } 2017\end{array}$ \\
\hline mGMGSx & $\begin{array}{l}\text { Golden-mantled Ground } \\
\text { Squirrel }\end{array}$ & $\begin{array}{l}\text { Callospermophilus } \\
\quad \text { lateralis }\end{array}$ & 930305 & 102855 & $\begin{array}{l}\text { ITIS and NatureServe recognize the splitting of } 8 \text { genera (Notocitellus, } \\
\text { Otospermophilus, Callospermophilus, Ictidomys, Poliocitellus, Xerospermophilus, } \\
\text { and Urocitellus) from Spermophilus (which is now restricted to Eurasia) based on } \\
\text { Helgen and others (2009). SGW } 29 \text { September } 2017\end{array}$ \\
\hline mGMGSb & $\begin{array}{l}\text { San Bernardino Golden- } \\
\text { mantled Ground } \\
\text { Squirrel }\end{array}$ & $\begin{array}{l}\text { Callospermophilus } \\
\text { lateralis bernardinus }\end{array}$ & 931060 & 807083 & $\begin{array}{l}\text { ITIS and NatureServe recognize the splitting of } 8 \text { genera (Notocitellus, } \\
\text { Otospermophilus, Callospermophilus, Ictidomys, Poliocitellus, Xerospermophilus, } \\
\text { and Urocitellus) from Spermophilus (which is now restricted to Eurasia) based on } \\
\text { Helgen and others (2009). SGW } 29 \text { September } 2017\end{array}$ \\
\hline mCGGSx & $\begin{array}{l}\text { Cascade Golden- } \\
\text { mantled Ground } \\
\text { Squirrel }\end{array}$ & $\begin{array}{l}\text { Callospermophilus } \\
\text { saturatus }\end{array}$ & 930304 & 102354 & $\begin{array}{l}\text { ITIS and NatureServe recognize the splitting of } 8 \text { genera (Notocitellus, } \\
\text { Otospermophilus, Callospermophilus, Ictidomys, Poliocitellus, Xerospermophilus, } \\
\text { and Urocitellus) from Spermophilus (which is now restricted to Eurasia) based on } \\
\text { Helgen and others (2009). SGW } 29 \text { September } 2017\end{array}$ \\
\hline
\end{tabular}


Table 3.1. Notes on species taxonomy related to the Integrated Taxonomic Information System and NatureServe's Global Element Identifiers for species where there was not a direct match with the taxonomic concept being modeled by Gap Analysis Project (GAP).-Continued

[ITIS, Integrated Taxonomic Information System; SGW, Steven G. Williams; USFWS, U.S. Fish and Wildlife Service; km, kilometer]

\begin{tabular}{|c|c|c|c|c|c|}
\hline $\begin{array}{l}\text { GAP } \\
\text { species } \\
\text { code }\end{array}$ & GAP common name & GAP scientific name & $\begin{array}{l}\text { Matching } \\
\text { ITIS } \\
\text { code }\end{array}$ & $\begin{array}{c}\text { Matching } \\
\text { NatureServe } \\
\text { Global Element ID }\end{array}$ & Taxa concept matching notes \\
\hline mWYSQx & $\begin{array}{l}\text { Wyoming Ground } \\
\text { Squirrel }\end{array}$ & Urocitellus elegans & 930319 & 102073 & $\begin{array}{l}\text { NatureServe does not recognize the subspecies Urocitellus elegans aureus or } U \text {. E. } \\
\text { elegans. SGW } 29 \text { September } 2017\end{array}$ \\
\hline mWYSQn & $\begin{array}{l}\text { Wyoming Ground } \\
\text { Squirrel (nevadensis) }\end{array}$ & $\begin{array}{l}\text { Urocitellus elegans } \\
\text { nevadensis }\end{array}$ & 931054 & 106011 & $\begin{array}{l}\text { NatureServe does not recognize the subspecies Urocitellus elegans aureus or U. E. } \\
\text { elegans. SGW } 29 \text { September } 2017\end{array}$ \\
\hline mWYSQa & $\begin{array}{l}\text { Wyoming Ground } \\
\text { Squirrel (aureus) }\end{array}$ & $\begin{array}{l}\text { Urocitellus elegans } \\
\text { aureus }\end{array}$ & 931053 & 102073 & $\begin{array}{l}\text { NatureServe does not recognize the subspecies Urocitellus elegans aureus or U. E. } \\
\text { elegans. SGW } 29 \text { September } 2017\end{array}$ \\
\hline mWYSQe & $\begin{array}{l}\text { Wyoming Ground } \\
\text { Squirrel (elegans) }\end{array}$ & $\begin{array}{l}\text { Urocitellus elegans } \\
\text { elegans }\end{array}$ & 931052 & 102073 & $\begin{array}{l}\text { NatureServe does not recognize the subspecies Urocitellus elegans aureus or } U \text {. E. } \\
\text { elegans. SGW } 29 \text { September } 2017\end{array}$ \\
\hline mPGSQx & Piute Ground Squirrel & Urocitellus mollis & 930320 & 102074 & $\begin{array}{l}\text { ITIS and NatureServe recognize the splitting of } 8 \text { genera (Notocitellus, } \\
\text { Otospermophilus, Callospermophilus, Ictidomys, Poliocitellus, Xerospermophilus, } \\
\text { and Urocitellus) from Spermophilus (which is now restricted to Eurasia) based on } \\
\text { Helgen and others (2009). SGW } 29 \text { September } 2017\end{array}$ \\
\hline mMGSQx & $\begin{array}{l}\text { Merriam's Ground } \\
\text { Squirrel }\end{array}$ & Urocitellus canus & 930317 & 101708 & $\begin{array}{l}\text { ITIS and NatureServe recognize the splitting of } 8 \text { genera (Notocitellus, } \\
\text { Otospermophilus, Callospermophilus, Ictidomys, Poliocitellus, Xerospermophilus, } \\
\text { and Urocitellus) from Spermophilus (which is now restricted to Eurasia) based on } \\
\text { Helgen and others (2009). SGW } 29 \text { September } 2017\end{array}$ \\
\hline mMAORx & Marsh Oryzomys & Oryzomys palustris & 180336 & 104423 & $\begin{array}{l}\text { The USFWS listed Oryzomys palustris natator as endangered in } 1991 \text { under the } \\
\text { common name Rice Rat and designated critical habitat in August } 1993 \text {. A 5-year } \\
\text { review in } 2008 \text { concluded the O. p. natator subspecies endangered status is to } \\
\text { remain unchanged. We added this subspecies due to conservation status and } \\
\text { distinct range (Perry 2006, USFWS 2008). NatureServe lists this subspecies as } \\
\text { Oryzomys palustris population } 3 \text { with the common name Key Oryzomys. ITIS } \\
\text { does not currently recognize any subspecies for O. palustris. SGW } 29 \text { September } \\
2017\end{array}$ \\
\hline mMAORn & Key Oryzomys & $\begin{array}{l}\text { Oryzomys palustris } \\
\text { natator }\end{array}$ & 180336 & 104405 & $\begin{array}{l}\text { The USFWS listed Oryzomys palustris natator as endangered in } 1991 \text { under the } \\
\text { common name Rice Rat and designated critical habitat in August 1993. A 5-year } \\
\text { review in } 2008 \text { concluded the O. p. natator subspecies endangered status is to } \\
\text { remain unchanged. We added this subspecies due to conservation status and } \\
\text { distinct range (Perry 2006, USFWS 2008). NatureServe lists this subspecies as } \\
\text { Oryzomys palustris population } 3 \text { with the common name Key Oryzomys. ITIS } \\
\text { does not currently recognize any subspecies for O. palustris. SGW } 29 \text { September } \\
2017\end{array}$ \\
\hline
\end{tabular}


Table 3.1. Notes on species taxonomy related to the Integrated Taxonomic Information System and NatureServe's Global Element Identifiers for species where there was not a direct match with the taxonomic concept being modeled by Gap Analysis Project (GAP).-Continued

[ITIS, Integrated Taxonomic Information System; SGW, Steven G. Williams; USFWS, U.S. Fish and Wildlife Service; km, kilometer]

\begin{tabular}{|c|c|c|c|c|c|}
\hline $\begin{array}{l}\text { GAP } \\
\text { species } \\
\text { code }\end{array}$ & GAP common name & GAP scientific name & $\begin{array}{l}\text { Matching } \\
\text { ITIS } \\
\text { code }\end{array}$ & $\begin{array}{c}\text { Matching } \\
\text { NatureServe } \\
\text { Global Element ID }\end{array}$ & Taxa concept matching notes \\
\hline mOLDEx & Oldfield Deermouse & Peromyscus polionotus & 180290 & 106418 & $\begin{array}{l}\text { ITIS does not recognize any subspecies for Peromyscus polionotus. Due to the } \\
\text { conservation status of several subspecies recognized by NatureServe, we chose } \\
\text { to map seven subspecies with distinct ranges (P. p. ammobates, P. p. trissyllepsis, } \\
\text { P. p. allophrys, P. p. phasma, P. p. leucocephalus, P. p. niveiventris, P. p. } \\
\text { peninsularis). SGW } 29 \text { September } 2017\end{array}$ \\
\hline mOLDEm & $\begin{array}{l}\text { Alabama Beach } \\
\text { Deermouse }\end{array}$ & $\begin{array}{l}\text { Peromyscus polionotus } \\
\text { ammobates }\end{array}$ & 180290 & 101301 & $\begin{array}{l}\text { ITIS does not recognize any subspecies for Peromyscus polionotus. Due to the } \\
\text { conservation status of several subspecies recognized by NatureServe, we chose } \\
\text { to map seven subspecies with distinct ranges (P. p. ammobates, P. p. trissyllepsis, } \\
\text { P. p. allophrys, P. p. phasma, P. p. leucocephalus, P. p. niveiventris, P. p. } \\
\text { peninsularis). SGW } 29 \text { September } 2017\end{array}$ \\
\hline mOLDEt & $\begin{array}{l}\text { Perdido Key Beach } \\
\text { Deermouse }\end{array}$ & $\begin{array}{l}\text { Peromyscus polionotus } \\
\quad \text { trissyllepsis }\end{array}$ & 180290 & 105073 & $\begin{array}{l}\text { ITIS does not recognize any subspecies for Peromyscus polionotus. Due to the } \\
\text { conservation status of several subspecies recognized by NatureServe, we chose } \\
\text { to map seven subspecies with distinct ranges (P. p. ammobates, P. p. trissyllepsis, } \\
\text { P. p. allophrys, P. p. phasma, P. p. leucocephalus, P. p. niveiventris, P. p. } \\
\text { peninsularis). SGW } 29 \text { September } 2017\end{array}$ \\
\hline mOLDEa & $\begin{array}{l}\text { Choctawhatchee Beach } \\
\text { Deermouse }\end{array}$ & $\begin{array}{l}\text { Peromyscus polionotus } \\
\quad \text { allophrys }\end{array}$ & 180290 & 100415 & $\begin{array}{l}\text { ITIS does not recognize any subspecies for Peromyscus polionotus. Due to the } \\
\text { conservation status of several subspecies recognized by NatureServe, we chose } \\
\text { to map seven subspecies with distinct ranges (P. p. ammobates, } P \text {. p. trissyllepsis, } \\
P . \text { p. allophrys, } P \text {. p. phasma, P. p. leucocephalus, P. p. niveiventris, } P . p \text {. } \\
\text { peninsularis). SGW } 29 \text { September } 2017\end{array}$ \\
\hline mOLDEh & $\begin{array}{l}\text { Anastasia Beach } \\
\text { Deermouse }\end{array}$ & $\begin{array}{l}\text { Peromyscus polionotus } \\
\text { phasma }\end{array}$ & 180290 & 105259 & $\begin{array}{l}\text { ITIS does not recognize any subspecies for Peromyscus polionotus. Due to the } \\
\text { conservation status of several subspecies recognized by NatureServe, we chose } \\
\text { to map seven subspecies with distinct ranges (P. p. ammobates, P. p. trissyllepsis, } \\
\text { P. p. allophrys, P. p. phasma, P. p. leucocephalus, P. p. niveiventris, P. p. } \\
\text { peninsularis). SGW } 29 \text { September } 2017\end{array}$ \\
\hline mOLDEl & $\begin{array}{l}\text { Santa Rosa Beach } \\
\text { Deermouse }\end{array}$ & $\begin{array}{l}\text { Peromyscus polionotus } \\
\text { leucocephalus }\end{array}$ & 180290 & 101599 & $\begin{array}{l}\text { ITIS does not recognize any subspecies for Peromyscus polionotus. Due to the } \\
\text { conservation status of several subspecies recognized by NatureServe, we chose } \\
\text { to map seven subspecies with distinct ranges (P. p. ammobates, } P \text {. p. trissyllepsis, } \\
\text { P. p. allophrys, } P \text {. p. phasma, } P \text {. p. leucocephalus, } P \text {. p. niveiventris, } P \text {. p. } \\
\text { peninsularis). SGW } 29 \text { September } 2017\end{array}$ \\
\hline mOLDEn & $\begin{array}{l}\text { Southeast Beach } \\
\text { Deermouse }\end{array}$ & $\begin{array}{l}\text { Peromyscus polionotus } \\
\text { niveiventris }\end{array}$ & 180290 & 102064 & $\begin{array}{l}\text { ITIS does not recognize any subspecies for Peromyscus polionotus. Due to the } \\
\text { conservation status of several subspecies recognized by NatureServe, we chose } \\
\text { to map seven subspecies with distinct ranges (P. p. ammobates, P. p. trissyllepsis, } \\
\text { P. p. allophrys, P. p. phasma, P. p. leucocephalus, P. p. niveiventris, P. p. } \\
\text { peninsularis). SGW } 29 \text { September } 2017\end{array}$ \\
\hline
\end{tabular}


Table 3.1. Notes on species taxonomy related to the Integrated Taxonomic Information System and NatureServe's Global Element Identifiers for species where there was not a direct match with the taxonomic concept being modeled by Gap Analysis Project (GAP).-Continued

[ITIS, Integrated Taxonomic Information System; SGW, Steven G. Williams; USFWS, U.S. Fish and Wildlife Service; km, kilometer]

\begin{tabular}{|c|c|c|c|c|c|}
\hline $\begin{array}{l}\text { GAP } \\
\text { species } \\
\text { code }\end{array}$ & GAP common name & GAP scientific name & $\begin{array}{l}\text { Matching } \\
\text { ITIS } \\
\text { code }\end{array}$ & $\begin{array}{c}\text { Matching } \\
\text { NatureServe } \\
\text { Global Element ID }\end{array}$ & Taxa concept matching notes \\
\hline mOLDEp & $\begin{array}{l}\text { St. Andrews Beach } \\
\text { Deermouse }\end{array}$ & $\begin{array}{l}\text { Peromyscus polionotus } \\
\quad \text { peninsularis }\end{array}$ & 180290 & 103306 & $\begin{array}{l}\text { ITIS does not recognize any subspecies for Peromyscus polionotus. Due to the } \\
\text { conservation status of several subspecies recognized by NatureServe, we chose } \\
\text { to map seven subspecies with distinct ranges (P. p. ammobates, } P \text {. p. trissyllepsis, } \\
\text { P. p. allophrys, P. p. phasma, P. p. leucocephalus, P. p. niveiventris, P. p. } \\
\text { peninsularis). SGW } 29 \text { September } 2017\end{array}$ \\
\hline mPIDEx & Pinon Deermouse & Peromyscus truei & 180291 & 100548 & $\begin{array}{l}\text { ITIS does not recognize any subspecies for Peromyscus truei. However, } \\
\text { NatureServe recognizes the subpecies P. t. comanche. We chose to map it due to } \\
\text { its conservation status and distinct range. SGW } 29 \text { September } 2017\end{array}$ \\
\hline mPIDEc & Palo Duro Deermouse & $\begin{array}{l}\text { Peromyscus truei } \\
\text { comanche }\end{array}$ & 180291 & 103019 & $\begin{array}{l}\text { ITIS does not recognize any subspecies for Peromyscus truei. However, } \\
\text { NatureServe recognizes the subpecies P. t. comanche. We chose to map it due to } \\
\text { its conservation status and distinct range. SGW } 29 \text { September } 2017\end{array}$ \\
\hline mACRAx & Arizona Cotton Rat & Sigmodon arizonae & 180347 & 106492 & $\begin{array}{l}\text { ITIS does not recognize any subspecies of Sigmodon arizonae. We chose to follow } \\
\text { the taxonomy recognized by NatureServe due to the distinct ranges of several } \\
\text { subspecies. SGW } 29 \text { September } 2017\end{array}$ \\
\hline mACRAp & $\begin{array}{l}\text { Colorado River Cotton } \\
\text { Rat }\end{array}$ & $\begin{array}{l}\text { Sigmodon arizonae } \\
\text { plenus }\end{array}$ & 180347 & 101792 & $\begin{array}{l}\text { ITIS does not recognize any subspecies of Sigmodon arizonae. We chose to follow } \\
\text { the taxonomy recognized by NatureServe due to the distinct ranges of several } \\
\text { subspecies. SGW } 29 \text { September } 2017\end{array}$ \\
\hline mACRAc & Arizona Cotton Rat & $\begin{array}{l}\text { Sigmodon arizonae } \\
\text { cienegae }\end{array}$ & 180347 & 791523 & $\begin{array}{l}\text { ITIS does not recognize any subspecies of Sigmodon arizonae. We chose to follow } \\
\text { the taxonomy recognized by NatureServe due to the distinct ranges of several } \\
\text { subspecies. SGW } 29 \text { September } 2017\end{array}$ \\
\hline mEAWOx & Eastern Woodrat & Neotoma floridana & 180372 & 100518 & $\begin{array}{l}\text { ITIS does not recognize any subspecies for Neotoma floridana. However, } \\
\text { NatureServe recognizes several subpecies. We chose to map N. f. smalli (Key } \\
\text { Largo Woodrat) due to its conservation status and distinct range. SGW } 29 \\
\text { September } 2017\end{array}$ \\
\hline mEAWOs & Key Largo Woodrat & $\begin{array}{l}\text { Neotoma floridana } \\
\text { smalli }\end{array}$ & 180372 & 104984 & $\begin{array}{l}\text { TIS does not recognize any subspecies for Neotoma floridana. However, } \\
\text { NatureServe recognizes several subpecies. We chose to map N. f. smalli (Key } \\
\text { Largo Woodrat) due to its conservation status and distinct range. SGW } 29 \\
\text { September } 2017\end{array}$ \\
\hline mDFWOx & Dusky-footed Woodrat & Neotoma fuscipes & 180373 & 768534 & $\begin{array}{l}\text { The San Joaquin Valley subspecies (Neotoma fuscipes riparia) of the } N \text {. fuscipes } \\
\text { (dusky-footed woodrat) is known to exist only in a single location (Caswell } \\
\text { Memorial State Park) along the Stanislaus River bordering San Joaquin and } \\
\text { Stanislaus counties, Calif. It was listed endangered by USFWS in } 1997 \text { (common } \\
\text { name of Riparian Woodrat). Because of the isolated range and high conservation } \\
\text { concern, this subspecies was included as a separate range and model from the full } \\
\text { N. fuscipes species model. ITIS does not recognize any subspecies of } N \text {. fuscipes. } \\
\text { SGW } 29 \text { September } 2017\end{array}$ \\
\hline
\end{tabular}


Table 3.1. Notes on species taxonomy related to the Integrated Taxonomic Information System and NatureServe's Global Element Identifiers for species where there was not a direct match with the taxonomic concept being modeled by Gap Analysis Project (GAP).-Continued

[ITIS, Integrated Taxonomic Information System; SGW, Steven G. Williams; USFWS, U.S. Fish and Wildlife Service; km, kilometer]

\begin{tabular}{|c|c|c|c|c|c|}
\hline $\begin{array}{l}\text { GAP } \\
\text { species } \\
\text { code }\end{array}$ & GAP common name & GAP scientific name & $\begin{array}{l}\text { Matching } \\
\text { ITIS } \\
\text { code }\end{array}$ & $\begin{array}{l}\text { Matching } \\
\text { NatureServe } \\
\text { Global Element ID }\end{array}$ & Taxa concept matching notes \\
\hline mDFWOs & $\begin{array}{l}\text { San Joaquin Valley } \\
\text { Wood Rat }\end{array}$ & $\begin{array}{l}\text { Neotoma fuscipes } \\
\quad \text { riparia }\end{array}$ & 180373 & 768539 & $\begin{array}{l}\text { The San Joaquin Valley subspecies (Neotoma fuscipes riparia) of the } N \text {. fuscipes } \\
\text { (dusky-footed woodrat) is known to exist only in a single location (Caswell } \\
\text { Memorial State Park) along the Stanislaus River bordering San Joaquin and } \\
\text { Stanislaus counties, Calif. It was listed endangered by USFWS in } 1997 \text { (common } \\
\text { name of Riparian Woodrat). Because of the isolated range and high conservation } \\
\text { concern, this subspecies was included as a separate range and model from the full } \\
N \text {. fuscipes species model. ITIS does not recognize any subspecies of } N \text {. fuscipes. } \\
\text { SGW } 29 \text { September } 2017\end{array}$ \\
\hline mSRBVx & $\begin{array}{l}\text { Southern Red-backed } \\
\text { Vole }\end{array}$ & Myodes gapperi & 970612 & 105153 & $\begin{array}{l}\text { ITIS does not recognize any subspecies for Myodes gapperi. However, NatureServe } \\
\text { recognizes several subpecies. We chose to map M. g. brevicaudus (Black Hills } \\
\text { Red-backed Vole) due to its conservation status and distinct range. SGW } 29 \\
\text { September } 2017\end{array}$ \\
\hline mSRBVb & $\begin{array}{l}\text { Black Hills Red-backed } \\
\text { Vole }\end{array}$ & $\begin{array}{l}\text { Myodes gapperi } \\
\text { brevicaudus }\end{array}$ & 970612 & 105999 & $\begin{array}{l}\text { ITIS does not recognize any subspecies for Myodes gapperi. However, NatureServe } \\
\text { recognizes several subpecies. We chose to map M. g. brevicaudus (Black Hills } \\
\text { Red-backed Vole) due to its conservation status and distinct range. SGW } 29 \\
\text { September } 2017\end{array}$ \\
\hline mMEVOx & Meadow Vole & $\begin{array}{l}\text { Microtus } \\
\text { pennsylvanicus }\end{array}$ & 180297 & 103729 & $\begin{array}{l}\text { ITIS does not recognize any subspecies for Microtus pennsylvanicus. However, } \\
\text { NatureServe recognizes several subpecies. We chose to map M. p. dukecampbelli } \\
\text { (Duke's Salt Marsh Vole) due to its conservation status and distinct range. SGW } \\
29 \text { September } 2017\end{array}$ \\
\hline mMEVOd & Duke’s Salt Marsh Vole & $\begin{array}{l}\text { Microtus } \\
\text { pennsylvanicus } \\
\text { dukecampbelli }\end{array}$ & 180297 & 106543 & $\begin{array}{l}\text { ITIS does not recognize any subspecies for Microtus pennsylvanicus. However, } \\
\text { NatureServe recognizes several subpecies. We chose to map M. p. dukecampbelli } \\
\text { (Duke’s Salt Marsh Vole) due to its conservation status and distinct range. SGW } \\
29 \text { September } 2017\end{array}$ \\
\hline mMOVOx & Montane Vole & Microtus montanus & 180310 & 104293 & $\begin{array}{l}\text { ITIS does not recognize any subspecies for Microtus montanus. However, } \\
\text { NatureServe recognizes several subpecies. We chose to map three subspecies ( } M \text {. } \\
\text { m. arizonensis, } M \text {. } m \text {. fucosus, } M \text {. m. nevadensis) due to their conservation status } \\
\text { and distinct ranges. SGW } 29 \text { September } 2017\end{array}$ \\
\hline mMOVOn & $\begin{array}{l}\text { Ash Meadows Montane } \\
\text { Vole }\end{array}$ & $\begin{array}{l}\text { Microtus montanus } \\
\text { nevadensis }\end{array}$ & 180310 & 101726 & $\begin{array}{l}\text { ITIS does not recognize any subspecies for Microtus montanus. However, } \\
\text { NatureServe recognizes several subpecies. We chose to map three subspecies ( } M \text {. } \\
\text { m. arizonensis, } M \text {. } m \text {. fucosus, } M \text {. } m \text {. nevadensis) due to their conservation status } \\
\text { and distinct ranges. SGW } 29 \text { September } 2017\end{array}$ \\
\hline mMOVOa & Arizona Montane Vole & $\begin{array}{l}\text { Microtus montanus } \\
\text { arizonensis }\end{array}$ & 180310 & 102377 & $\begin{array}{l}\text { ITIS does not recognize any subspecies for Microtus montanus. However, } \\
\text { NatureServe recognizes several subpecies. We chose to map three subspecies ( } M \text {. } \\
\text { m. arizonensis, } M \text {. m. fucosus, } M \text {. m. nevadensis) due to their conservation status } \\
\text { and distinct ranges. SGW } 29 \text { September } 2017\end{array}$ \\
\hline
\end{tabular}


Table 3.1. Notes on species taxonomy related to the Integrated Taxonomic Information System and NatureServe's Global Element Identifiers for species where there was not a direct match with the taxonomic concept being modeled by Gap Analysis Project (GAP).-Continued

[ITIS, Integrated Taxonomic Information System; SGW, Steven G. Williams; USFWS, U.S. Fish and Wildlife Service; km, kilometer]

\begin{tabular}{|c|c|c|c|c|c|}
\hline $\begin{array}{l}\text { GAP } \\
\text { species } \\
\text { code }\end{array}$ & GAP common name & GAP scientific name & $\begin{array}{l}\text { Matching } \\
\text { ITIS } \\
\text { code }\end{array}$ & $\begin{array}{c}\text { Matching } \\
\text { NatureServe } \\
\text { Global Element ID }\end{array}$ & Taxa concept matching notes \\
\hline mMOVOf & Pahranagat Valley Vole & $\begin{array}{l}\text { Microtus montanus } \\
\quad \text { fucosus }\end{array}$ & 180310 & 101211 & $\begin{array}{l}\text { ITIS does not recognize any subspecies for Microtus montanus. However, } \\
\text { NatureServe recognizes several subpecies. We chose to map three subspecies (M. } \\
\text { m. arizonensis, } M \text {. } m \text {. fucosus, } M \text {. m. nevadensis) due to their conservation status } \\
\text { and distinct ranges. SGW } 29 \text { September } 2017\end{array}$ \\
\hline mCAVOx & California Vole & Microtus californicus & 180305 & 102779 & $\begin{array}{l}\text { ITIS does not recognize any subspecies for Microtus californicus. However, } \\
\text { NatureServe recognizes several subpecies. We chose to map M. c. scirpensis } \\
\text { (Amargosa Vole) due to its conservation status and distinct range. SGW } 29 \\
\text { September } 2017\end{array}$ \\
\hline mCAVOc & Amargosa Vole & $\begin{array}{l}\text { Microtus californicus } \\
\text { scirpensis }\end{array}$ & 180305 & 101942 & $\begin{array}{l}\text { ITIS does not recognize any subspecies for Microtus californicus. However, } \\
\text { NatureServe recognizes several subpecies. We chose to map M. c. scirpensis } \\
\text { (Amargosa Vole) due to its conservation status and distinct range. SGW } 29 \\
\text { September } 2017\end{array}$ \\
\hline mLTVOx & Long-tailed Vole & Microtus longicaudus & 180299 & 102513 & $\begin{array}{l}\text { ITIS does not recognize any subspecies for Microtus longicaudus. However, } \\
\text { NatureServe recognizes several subpecies. We chose to map M. l. leucophaeus } \\
\text { (White-bellied Vole) due to its conservation status and distinct range. SGW } 29 \\
\text { September } 2017\end{array}$ \\
\hline mLTVOl & White-bellied Vole & $\begin{array}{l}\text { Microtus longicaudus } \\
\text { leucophaeus }\end{array}$ & 180299 & 102845 & $\begin{array}{l}\text { ITIS does not recognize any subspecies for Microtus longicaudus. However, } \\
\text { NatureServe recognizes several subpecies. We chose to map M. l. leucophaeus } \\
\text { (White-bellied Vole) due to its conservation status and distinct range. SGW } 29 \\
\text { September } 2017\end{array}$ \\
\hline mROVOx & Rock Vole & Microtus chrotorrhinus & 180307 & 103836 & $\begin{array}{l}\text { ITIS does not recognize any subspecies for Microtus chrotorrhinus. However, } \\
\text { NatureServe recognizes the subpecies M. c. carolinensis (Southern Rock Vole). } \\
\text { We chose to map it due to it’s conservation status and distinct range. SGW } 29 \\
\text { September } 2017\end{array}$ \\
\hline mROVOc & Southern Rock Vole & $\begin{array}{l}\text { Microtus chrotorrhinus } \\
\text { carolinensis }\end{array}$ & 180307 & 105684 & $\begin{array}{l}\text { ITIS does not recognize any subspecies for Microtus chrotorrhinus. However, } \\
\text { NatureServe recognizes the subpecies } M \text {. c. carolinensis (Southern Rock Vole). } \\
\text { We chose to map it due to it’s conservation status and distinct range. SGW } 29 \\
\text { September } 2017\end{array}$ \\
\hline mPRVOx & Prairie Vole & Microtus ochrogaster & 180312 & 101287 & $\begin{array}{l}\text { ITIS does not recognize any subspecies for Microtus ochrogaster. However, } \\
\text { NatureServe recognizes several subpecies. We chose to map M. o. taylori (Prairie } \\
\text { Vole) due to its conservation status and distinct range. SGW } 29 \text { September } 2017\end{array}$ \\
\hline mPRVOt & Prairie Vole & $\begin{array}{l}\text { Microtus ochrogaster } \\
\text { taylori }\end{array}$ & 180312 & 101969 & $\begin{array}{l}\text { ITIS does not recognize any subspecies for Microtus ochrogaster. However, } \\
\text { NatureServe recognizes several subpecies. We chose to map M. o. taylori (Prairie } \\
\text { Vole) due to its conservation status and distinct range. SGW } 29 \text { September } 2017\end{array}$ \\
\hline
\end{tabular}


Table 3.1. Notes on species taxonomy related to the Integrated Taxonomic Information System and NatureServe's Global Element Identifiers for species where there was not a direct match with the taxonomic concept being modeled by Gap Analysis Project (GAP).-Continued

[ITIS, Integrated Taxonomic Information System; SGW, Steven G. Williams; USFWS, U.S. Fish and Wildlife Service; km, kilometer]

\begin{tabular}{|c|c|c|c|c|c|}
\hline $\begin{array}{l}\text { GAP } \\
\text { species } \\
\text { code }\end{array}$ & GAP common name & GAP scientific name & $\begin{array}{l}\text { Matching } \\
\text { ITIS } \\
\text { code }\end{array}$ & $\begin{array}{c}\text { Matching } \\
\text { NatureServe } \\
\text { Global Element ID }\end{array}$ & Taxa concept matching notes \\
\hline mKIFOx & Kit Fox & Vulpes macrotis & 180606 & 102982 & $\begin{array}{l}\text { ITIS does not recognize any subspecies for Vulpes macrotis. However, NatureServe } \\
\text { recognizes the subpecies } V \text {. } m \text {. mutica (Kit Fox-San Joaquin Valley population). } \\
\text { We chose to map it due to its conservation status and distinct range. SGW } 29 \\
\text { September } 2017\end{array}$ \\
\hline mKIFOm & $\begin{array}{l}\text { Kit Fox - San Joaquin } \\
\text { Valley Population }\end{array}$ & Vulpes macrotis mutica & 180606 & 101320 & $\begin{array}{l}\text { ITIS does not recognize any subspecies for Vulpes macrotis. However, NatureServe } \\
\text { recognizes the subpecies } V \text {. } m \text {. mutica (Kit Fox-San Joaquin Valley population). } \\
\text { We chose to map it due to its conservation status and distinct range. SGW } 29 \\
\text { September } 2017\end{array}$ \\
\hline mCOUGx & Cougar & Puma concolor & 552479 & 101637 & $\begin{array}{l}\text { ITIS does not recognize Puma concolor coryi (Florida Panther) subspecies. } \\
\text { However, NatureServe recognizes the subpecies. We chose to map it due to its } \\
\text { conservation status and distinct range. SGW } 29 \text { September } 2017\end{array}$ \\
\hline mCOUGc & Florida Panther & Puma concolor coryi & 552479 & 101183 & $\begin{array}{l}\text { ITIS does not recognize Puma concolor coryi (Florida Panther) subspecies. } \\
\text { However, NatureServe recognizes the subpecies. We chose to map it due to its } \\
\text { conservation status and distinct range. SGW } 29 \text { September } 2017\end{array}$ \\
\hline mJAGDx & Jaguarundi & Puma yagouarondi & 726257 & 103451 & $\begin{array}{l}\text { NatureServe recognizes this genus as Herpailurus according to Caso and others } \\
\text { (2015). SGW } 29 \text { September } 2017\end{array}$ \\
\hline mJAGDc & Gulf Coast Jaguarundi & $\begin{array}{l}\text { Puma yagouaroundi } \\
\text { cacomitli }\end{array}$ & 726436 & 104968 & $\begin{array}{l}\text { NatureServe recognizes this genus as Herpailurus according to Caso and others } \\
\text { (2015). SGW } 29 \text { September } 2017\end{array}$ \\
\hline mELK1x & Elk & Cervus elaphus & 180695 & 102257 & $\begin{array}{l}\text { Cervus elaphus subspecies of C. e. nannodes and C. e. roosevelti (Tule and } \\
\text { Roosevelt elk, respectively) were included because of their definitive ranges and } \\
\text { conservation concern from a historical perspective. ITIS does not recognize C. e. } \\
\text { roosevelti. SGW } 29 \text { September } 2017\end{array}$ \\
\hline mELK1t & Tule Elk & $\begin{array}{l}\text { Cervus elaphus } \\
\text { nannodes }\end{array}$ & 898525 & 103199 & $\begin{array}{l}\text { Cervus elaphus subspecies of C. e. nannodes and C. e. roosevelti (Tule and } \\
\text { Roosevelt elk, respectively) were included because of their definitive ranges and } \\
\text { conservation concern from a historical perspective. ITIS does not recognize C. e. } \\
\text { roosevelti. SGW } 29 \text { September } 2017\end{array}$ \\
\hline mELK1r & Roosevelt Elk & $\begin{array}{l}\text { Cervus elaphus } \\
\text { roosevelti }\end{array}$ & 180695 & 101331 & $\begin{array}{l}\text { Cervus elaphus subspecies of C. e. nannodes and C. e. roosevelti (Tule and } \\
\text { Roosevelt elk, respectively) were included because of their definitive ranges and } \\
\text { conservation concern from a historical perspective. ITIS does not recognize C. e. } \\
\text { roosevelti. SGW } 29 \text { September } 2017\end{array}$ \\
\hline rSUCOx & Suwannee Cooter & $\begin{array}{l}\text { Pseudemys } \\
\quad \text { suwanniensis }\end{array}$ & 668673 & 102277 & $\begin{array}{l}\text { Crother and others (2000, 2003) and Crother (2008) delineate Pseudemys } \\
\text { suwanniensis (Suwannee Cooter) as a full species. Both NatureServe and ITIS } \\
\text { currently treat P. suwanniensis as a subspecies (P. concinna suwanniensis). SGW } \\
29 \text { September } 2017\end{array}$ \\
\hline
\end{tabular}


Table 3.1. Notes on species taxonomy related to the Integrated Taxonomic Information System and NatureServe's Global Element Identifiers for species where there was not a direct match with the taxonomic concept being modeled by Gap Analysis Project (GAP).-Continued

[ITIS, Integrated Taxonomic Information System; SGW, Steven G. Williams; USFWS, U.S. Fish and Wildlife Service; km, kilometer]

\begin{tabular}{|c|c|c|c|c|c|}
\hline $\begin{array}{l}\text { GAP } \\
\text { species } \\
\text { code }\end{array}$ & GAP common name & GAP scientific name & $\begin{array}{l}\text { Matching } \\
\text { ITIS } \\
\text { code }\end{array}$ & $\begin{array}{c}\text { Matching } \\
\text { NatureServe } \\
\text { Global Element ID }\end{array}$ & Taxa concept matching notes \\
\hline rEBTUx & Eastern Box Turtle & Terrapene carolina & 173776 & 100312 & $\begin{array}{l}\text { ITIS does not recognize Terrapene carolina bauri (Florida Box Turtle) subspecies. } \\
\text { However, NatureServe recognizes the subpecies. We chose to map it due to its } \\
\text { conservation status and distinct range. SGW } 29 \text { September } 2017\end{array}$ \\
\hline rEBTUb & Florida Box Turtle & $\begin{array}{l}\text { Terrapene carolina } \\
\quad \text { bauri }\end{array}$ & 173776 & 105431 & $\begin{array}{l}\text { ITIS does not recognize Terrapene carolina bauri (Florida Box Turtle) subspecies. } \\
\text { However, NatureServe recognizes the subpecies. We chose to map it due to its } \\
\text { conservation status and distinct range. SGW } 29 \text { September } 2017\end{array}$ \\
\hline rDSLIx & Desert Spiny Lizard & Sceloporus magister & 173873 & 106473 & $\begin{array}{l}\text { NatureServe does not recognize either Sceloporus bimaculosus or S. uniformis as } \\
\text { distinct species, but rather part of the S. magister complex. SGW } 29 \text { September } \\
2017\end{array}$ \\
\hline rTSSLx & $\begin{array}{l}\text { Twin-spotted Spiny } \\
\text { Lizard }\end{array}$ & Sceloporus bimaculosus & 1056655 & 106473 & $\begin{array}{l}\text { NatureServe does not recognize either Sceloporus bimaculosus or S. uniformis as } \\
\text { distinct species, but rather part of the S. magister complex. SGW } 29 \text { September } \\
2017\end{array}$ \\
\hline rYBSLx & $\begin{array}{l}\text { Yellow-backed Spiny } \\
\text { Lizard }\end{array}$ & Sceloporus uniformis & 1056662 & 106473 & $\begin{array}{l}\text { NatureServe does not recognize either Sceloporus bimaculosus or S. uniformis as } \\
\text { distinct species, but rather part of the S. magister complex. SGW } 29 \text { September } \\
2017\end{array}$ \\
\hline rCSWHx & $\begin{array}{l}\text { Canyon Spotted } \\
\text { Whiptail }\end{array}$ & Aspidoscelis burti & 174015 & 106385 & $\begin{array}{l}\text { Reeder and others (2002) split North American species of the genus Cnemidophorus } \\
\text { into the genus Aspidoscelis. ITIS recognizes Aspidoscelis burti as Cnemidophorus } \\
\text { burti (TSN 174015). SGW } 29 \text { September } 2017\end{array}$ \\
\hline rRBWHx & Red-backed Whiptail & Aspidoscelis xanthonota & 564600 & 101123 & $\begin{array}{l}\text { Reeder and others, (2002) split North American species of the genus Cnemidophorus } \\
\text { into the genus Aspidoscelis. ITIS recognizes Aspidoscelis xanthonota as } \\
\text { Cnemidophorus xanthonotus (TSN 564600). SGW } 29 \text { September } 2017\end{array}$ \\
\hline rGCWHx & $\begin{array}{l}\text { Gray Checkered } \\
\text { Whiptail }\end{array}$ & Aspidoscelis dixoni & 174016 & 106265 & $\begin{array}{l}\text { Reeder and others (2002) split North American species of the genus Cnemidophorus } \\
\text { into the genus Aspidoscelis. ITIS recognizes Aspidoscelis dixoni as } \\
\text { Cnemidophorus dixoni (TSN 174016). SGW } 29 \text { September } 2017\end{array}$ \\
\hline rCWHIx & $\begin{array}{l}\text { Chihuahuan Spotted } \\
\text { Whiptail }\end{array}$ & Aspidoscelis exsanguis & 174017 & 103253 & $\begin{array}{l}\text { Reeder and others (2002) split North American species of the genus Cnemidophorus } \\
\text { into the genus Aspidoscelis. ITIS recognizes Aspidoscelis exsanguis as } \\
\text { Cnemidophorus exsanguis (TSN 174017). SGW } 29 \text { September } 2017\end{array}$ \\
\hline rGLSWx & Gila Spotted Whiptail & $\begin{array}{l}\text { Aspidoscelis } \\
\quad \text { flagellicauda }\end{array}$ & 174018 & 101721 & $\begin{array}{l}\text { Reeder and others (2002) split North American species of the genus Cnemidophorus } \\
\text { into the genus Aspidoscelis. ITIS recognizes Aspidoscelis flagellicauda as } \\
\text { Cnemidophorus flagellicaudus (TSN 174018). SGW } 29 \text { September } 2017\end{array}$ \\
\hline rCSPWx & $\begin{array}{l}\text { Common Spotted } \\
\text { Whiptail }\end{array}$ & Aspidoscelis gularis & 174019 & 100575 & $\begin{array}{l}\text { Reeder and others (2002) split North American species of the genus Cnemidophorus } \\
\text { into the genus Aspidoscelis. ITIS recognizes Aspidoscelis gularis as } \\
\text { Cnemidophorus gularis (TSN 174019). SGW } 29 \text { September } 2017\end{array}$ \\
\hline
\end{tabular}


Table 3.1. Notes on species taxonomy related to the Integrated Taxonomic Information System and NatureServe's Global Element Identifiers for species where there was not a direct match with the taxonomic concept being modeled by Gap Analysis Project (GAP).-Continued

[ITIS, Integrated Taxonomic Information System; SGW, Steven G. Williams; USFWS, U.S. Fish and Wildlife Service; km, kilometer]

\begin{tabular}{|c|c|c|c|c|c|}
\hline $\begin{array}{l}\text { GAP } \\
\text { species } \\
\text { code }\end{array}$ & GAP common name & GAP scientific name & $\begin{array}{l}\text { Matching } \\
\text { ITIS } \\
\text { code }\end{array}$ & $\begin{array}{c}\text { Matching } \\
\text { NatureServe } \\
\text { Global Element ID }\end{array}$ & Taxa concept matching notes \\
\hline rORWHx & $\begin{array}{l}\text { Orange-throated } \\
\text { Whiptail }\end{array}$ & Aspidoscelis hyperythra & 174020 & 100457 & $\begin{array}{l}\text { Reeder and others (2002) split North American species of the genus Cnemidophorus } \\
\text { into the genus Aspidoscelis. ITIS recognizes Aspidoscelis hyperythra as } \\
\text { Cnemidophorus hyperythrus (TSN 174020). SGW } 29 \text { September } 2017\end{array}$ \\
\hline rLISWx & Little Striped Whiptail & Aspidoscelis inornata & 174021 & 106231 & $\begin{array}{l}\text { Reeder and others (2002) split North American species of the genus Cnemidophorus } \\
\text { into the genus Aspidoscelis. ITIS recognizes Aspidoscelis inornata as } \\
\text { Cnemidophorus inornatus (TSN 174021). SGW } 29 \text { September } 2017\end{array}$ \\
\hline rASWHx & $\begin{array}{l}\text { Arizona Striped } \\
\text { Whiptail }\end{array}$ & Aspidoscelis arizonae & 208930 & 106205 & $\begin{array}{l}\text { Reeder and others (2002) split North American species of the genus Cnemidophorus } \\
\text { into the genus Aspidoscelis. ITIS recognizes Aspidoscelis arizonae as } \\
\text { Cnemidophorus inornatus arizonae (TSN 208930). SGW } 29 \text { September } 2017\end{array}$ \\
\hline rLWWHx & Little White Whiptail & Aspidoscelis gypsi & 174021 & 106231 & $\begin{array}{l}\text { Aspidoscelis gypsi (Little White Whiptail) is recognized by Crother and others } \\
\text { (2000) and Collins and Taggart (2002) as a distinct species. ITIS and NatureServe } \\
\text { recognize this as part of Aspidoscelis inornatus or Cnemidophorus inornatus } \\
\text { (TSN 174021), respectively. SGW } 29 \text { September } 2017\end{array}$ \\
\hline rLASWx & Laredo Striped Whiptail & Aspidoscelis laredoensis & 174022 & 104626 & $\begin{array}{l}\text { Reeder and others (2002) split North American species of the genus Cnemidophorus } \\
\text { into the genus Aspidoscelis. ITIS recognizes Aspidoscelis laredoensis as } \\
\text { Cnemidophorus laredoensis (TSN 174022). SGW } 29 \text { September } 2017\end{array}$ \\
\hline rNMWHx & New Mexico Whiptail & $\begin{array}{l}\text { Aspidoscelis } \\
\text { neomexicana }\end{array}$ & 174024 & 103871 & $\begin{array}{l}\text { Reederand others (2002) split North American species of the genus Cnemidophorus } \\
\text { into the genus Aspidoscelis. ITIS recognizes Aspidoscelis neomexicana as } \\
\text { Cnemidophorus neomexicanus (TSN 174024). SGW } 29 \text { September } 2017\end{array}$ \\
\hline rSLRAx & Six-lined Racerunner & Aspidoscelis sexlineata & 174014 & 102815 & $\begin{array}{l}\text { Reeder and others (2002) split North American species of the genus Cnemidophorus } \\
\text { into the genus Aspidoscelis. ITIS recognizes Aspidoscelis sexlineata as } \\
\text { Cnemidophorus sexlineatus (TSN 174014). SGW } 29 \text { September } 2017\end{array}$ \\
\hline rSSWHx & $\begin{array}{l}\text { Sonoran Spotted } \\
\text { Whiptail }\end{array}$ & Aspidoscelis sonorae & 174025 & 102752 & $\begin{array}{l}\text { Reeder and others (2002) split North American species of the genus Cnemidophorus } \\
\text { into the genus Aspidoscelis. ITIS recognizes Aspidoscelis sonorae as } \\
\text { Cnemidophorus sonorae (TSN 174025). SGW } 29 \text { September } 2017\end{array}$ \\
\hline rCCWHx & $\begin{array}{l}\text { Common Checkered } \\
\text { Whiptail }\end{array}$ & Aspidoscelis tesselata & 174026 & 100978 & $\begin{array}{l}\text { Reeder and others (2002) split North American species of the genus Cnemidophorus } \\
\text { into the genus Aspidoscelis. ITIS recognizes Aspidoscelis tesselata as } \\
\text { Cnemidophorus tesselatus (TSN 174026). SGW } 29 \text { September } 2017\end{array}$ \\
\hline rTIWHx & Tiger Whiptail & Aspidoscelis tigris & 208940 & 102095 & $\begin{array}{l}\text { Reeder and others (2002) split North American species of the genus Cnemidophorus } \\
\text { into the genus Aspidoscelis. ITIS recognizes Aspidoscelis tigris as Cnemidophorus } \\
\text { tigris (TSN 208940). SGW } 29 \text { September } 2017\end{array}$ \\
\hline rDGWHx & $\begin{array}{l}\text { Desert Grassland } \\
\text { Whiptail }\end{array}$ & Aspidoscelis uniparens & 208947 & 102521 & $\begin{array}{l}\text { Reeder and others (2002) split North American species of the genus Cnemidophorus } \\
\text { into the genus Aspidoscelis. ITIS recognizes Aspidoscelis uniparens as } \\
\text { Cnemidophorus uniparens (TSN 208947). SGW } 29 \text { September } 2017\end{array}$ \\
\hline
\end{tabular}


Table 3.1. Notes on species taxonomy related to the Integrated Taxonomic Information System and NatureServe's Global Element Identifiers for species where there was not a direct match with the taxonomic concept being modeled by Gap Analysis Project (GAP).-Continued

[ITIS, Integrated Taxonomic Information System; SGW, Steven G. Williams; USFWS, U.S. Fish and Wildlife Service; km, kilometer]

\begin{tabular}{|c|c|c|c|c|c|}
\hline $\begin{array}{l}\text { GAP } \\
\text { species } \\
\text { code }\end{array}$ & GAP common name & GAP scientific name & $\begin{array}{l}\text { Matching } \\
\text { ITIS } \\
\text { code }\end{array}$ & $\begin{array}{c}\text { Matching } \\
\text { NatureServe } \\
\text { Global Element ID }\end{array}$ & Taxa concept matching notes \\
\hline rPLSWx & Plateau Striped Whiptail & Aspidoscelis velox & 208948 & 101656 & $\begin{array}{l}\text { Reeder and others (2002) split North American species of the genus Cnemidophorus } \\
\text { into the genus Aspidoscelis. ITIS recognizes Aspidoscelis velox as Cnemidophorus } \\
\text { velox (TSN 208948). SGW } 29 \text { September } 2017\end{array}$ \\
\hline rPLWHx & $\begin{array}{l}\text { Plateau Spotted } \\
\text { Whiptail }\end{array}$ & Aspidoscelis scalaris & 208925 & 104230 & $\begin{array}{l}\text { Reeder and others (2002) split North American species of the genus Cnemidophorus } \\
\text { into the genus Aspidoscelis. ITIS recognizes Aspidoscelis scalaris as } \\
\text { Cnemidophorus septemvittatus (TSN 208925). SGW } 29 \text { September } 2017\end{array}$ \\
\hline rCCHWx & $\begin{array}{l}\text { Colorado Checkered } \\
\text { Whiptail }\end{array}$ & $\begin{array}{l}\text { Aspidoscelis } \\
\quad \text { neotesselata }\end{array}$ & 914103 & 103410 & $\begin{array}{l}\text { Reeder and others (2002) split North American species of the genus Cnemidophorus } \\
\text { into the genus Aspidoscelis. ITIS recognizes Aspidoscelis neotesselata as } \\
\text { Cnemidophorus neotesselatus (TSN 914103). SGW } 29 \text { September } 2017\end{array}$ \\
\hline rPASWx & Pai Striped Whiptail & Aspidoscelis pai & 914099 & 637965 & $\begin{array}{l}\text { Reeder and others (2002) split North American species of the genus Cnemidophorus } \\
\text { into the genus Aspidoscelis. ITIS recognizes Aspidoscelis pai as Cnemidophorus } \\
\text { pai (TSN 914103). SGW } 29 \text { September } 2017\end{array}$ \\
\hline rSINLx & Sierra Night Lizard & Xantusia sierrae & 208992 & 102131 & $\begin{array}{l}\text { ITIS recognizes Xantusia sierraeas the subspecies Xantusia vigilis sierrae (TSN } \\
\text { 208992). SGW } 29 \text { September } 2017\end{array}$ \\
\hline rANLIx & Arizona Night Lizard & Xantusia arizonae & 208991 & 100054 & $\begin{array}{l}\text { ITIS recognizes Xantusia arizonae as the subspecies Xantusia vigilis arizonae (TSN } \\
\text { 208991). SGW } 29 \text { September } 2017\end{array}$ \\
\hline rWNLIx & Wiggins’ Night Lizard & Xantusia wigginsi & 174092 & 830036 & $\begin{array}{l}\text { Based on mitochondrial and nuclear DNA data, Sinclair and others (2004) and } \\
\text { Leavitt and others. (2007) determined that Xantusia wigginsi is a valid species } \\
\text { split from the Xantusia vigilis complex that occurs in the northern half of Baja } \\
\text { California and extreme south-central California. ITIS does not recognize X. } \\
\text { wigginsi as a distinct species. SGW } 29 \text { September } 2017\end{array}$ \\
\hline rDHNSx & Dusty Hog-nosed Snake & Heterodon gloydi & 209163 & 104992 & $\begin{array}{l}\text { ITIS recognizes Heterodon gloydi the subspecies Heterodon nasicus gloydi (TSN } \\
\text { 209163). SGW } 29 \text { September } 2017 .\end{array}$ \\
\hline rDENIx & Desert Nightsnake & Hypsiglena chlorophaea & 174233 & 817007 & $\begin{array}{l}\text { Hypsiglena chlorophaea (Desert Nightsnake) is recognized by Mulcahy (2008) } \\
\text { as a distinct species. ITIS recognizes this as part of Hypsiglena torquata (TSN } \\
\text { 174233). SGW } 29 \text { September } 2017\end{array}$ \\
\hline rCHNIx & Chihuahuan Nightsnake & Hypsiglena jani & 174233 & 817057 & $\begin{array}{l}\text { Hypsiglena jani (Chihuahuan Nightsnake) is recognized by Mulcahy (2008) as } \\
\text { a distinct species. ITIS recognizes this as part of Hypsiglena torquata (TSN } \\
\text { 174233). SGW } 29 \text { September } 2017\end{array}$ \\
\hline rCOACx & Coachwhip & Coluber flagellum & 174238 & 103744 & $\begin{array}{l}\text { ITIS recognizes Coluber flagellum (Coachwhip) as Masticophis flagellum (TSN } \\
\text { 174238). SGW } 29 \text { September } 2017\end{array}$ \\
\hline rBCCOx & $\begin{array}{l}\text { Baja California } \\
\text { Coachwhip }\end{array}$ & Coluber fuliginosus & 683039 & 857787 & $\begin{array}{l}\text { ITIS recognizes Coluber fuliginosus (Baja California Coachwhip) as Masticophis } \\
\text { fuliginosus (TSN 683039). SGW } 29 \text { September } 2017\end{array}$ \\
\hline
\end{tabular}




\section{Appendix 4. Table of Ancillary Datasets}

Table 4.1. Ancillary data used to create species' habitat maps and URLs to access those data through U.S. Geological Survey ScienceBase.

\begin{tabular}{ll}
\hline \multicolumn{1}{c}{ Ancillary data } & \multicolumn{1}{c}{ ScienceBase URL } \\
\hline National Gap Land Cover ver 1.0 (2001) & https://doi.org/10.5066/F7959GF5 \\
\hline Hydrologic Unit Codes [HUCs] & https://doi.org/10.5066/F7DZ0754 \\
\hline Modeling regions & https://doi.org/10.5066/F77H1HGT \\
\hline Human impact avoidance & https://doi.org/10.5066/F7PC318R \\
\hline Forest Edge & https://doi.org/10.5066/F7XW4HPN \\
Forest/open + woodland/shrubland & https://doi.org/10.5066/F7T43RZ7 \\
Elevation & https://doi.org/10.5066/F72N515B \\
Aspect & https://doi.org/10.5066/F7FT8JXP \\
\hline Slope & https://doi.org/10.5066/F75D8QQF \\
Hydrography & https://doi.org/10.5066/F7JM28J1 \\
Canopy cover & https://doi.org/10.5066/F76D5RW8 \\
\hline
\end{tabular}



Center Director, USGS Core Science Analytics and Synthesis Director, Science Analytics and Synthesis

U.S. Geological Survey

Box 25046, Mail Stop 302

Denver, CO 80225-004

(303) 202-4774

Or visit the Science Analytics and Synthesis website at https://www.usgs.gov/core-science-systems/science-analytics-andsynthesis/

Publishing support provided by the Denver and West Trenton Publishing Service Centers 


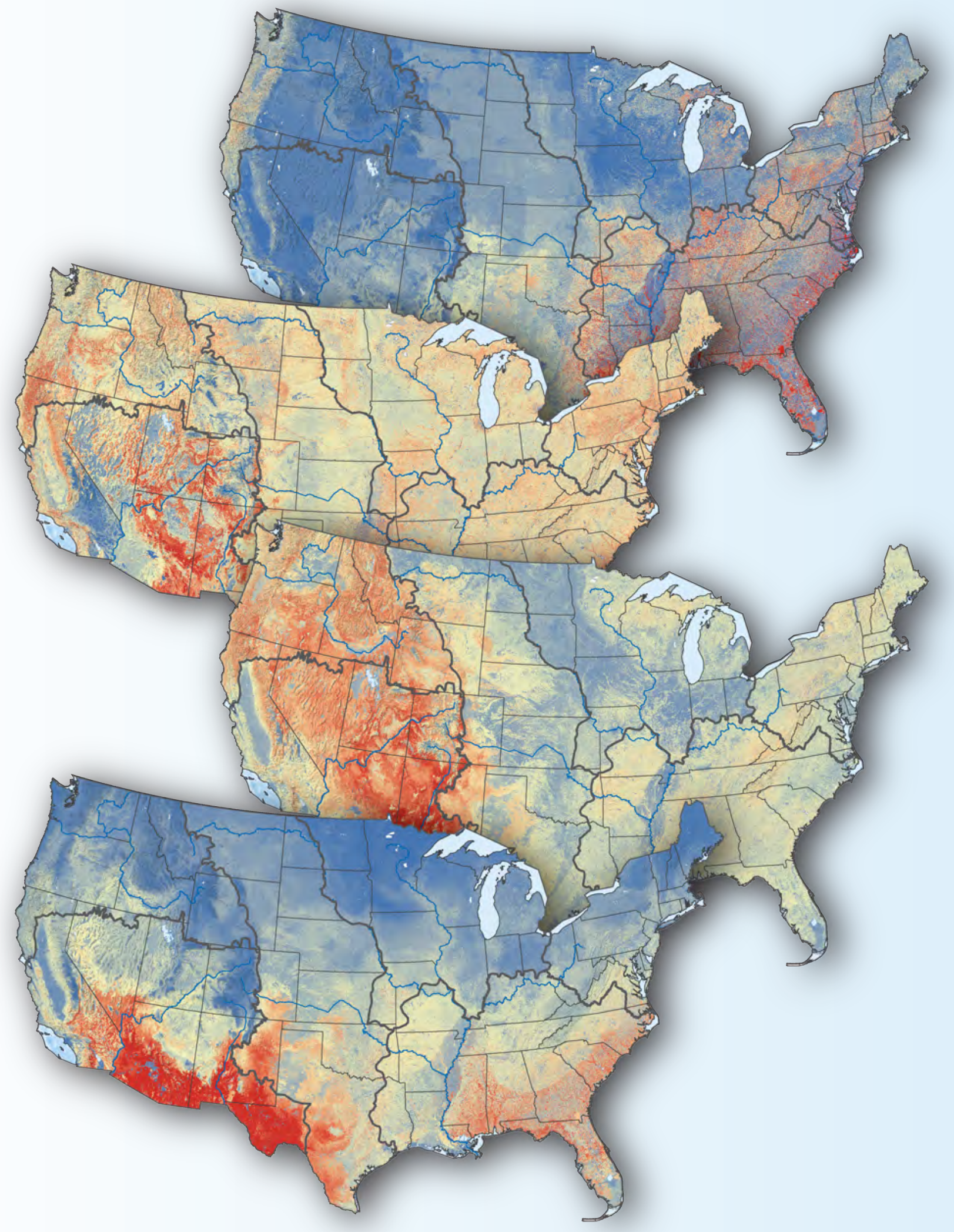

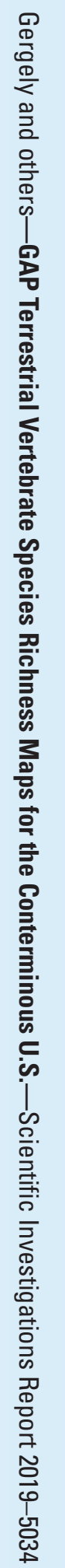

